\title{
COMUNICAÇÃO DE RISCOS AMBIENTAIS - UMA FERRAMENTA PARA A TOMADA DE DECISÃO \\ Estudo de Caso: projeto de incineração de resíduos sólidos domiciliares para a cidade de São Paulo
}

\section{CILENE VICTOR DA SILVA}

Tese de Doutorado apresentada ao Departamento de Saúde Ambiental da Faculdade de Saúde Pública da Universidade de São Paulo para obtenção do Grau de Doutor.

Área de Concentraçào: Saúde Ambiental

ORIENTADOR: PROFESSOR TITULAR CARLOS CELSO DO AMARAL E SILVA

São Paulo

2001 
Dedico este trabalho à minha mãe Noemia. razão de todo meu amor. A minha sobrinha-neta. Isabella. meu anjinho da guarda aqui na Terra. A memória de minha amiga Cristina Cibils. 


\section{AGRADECIMENTOS}

Ao Professor Carlos Celso do Amaral e Silva pela orientação, confiança e incentivo constantes, tornando possivel a realização deste estudo.

Ao Professor Carlos Manuel Chaparro pelas ricas contribuições durante a qualificaçào.

Á Professora Helena Ribeiro pelas importantes observações e sugestões durante a qualificação.

À Professora Adelaide Nardocci pela valiosa contribuição e orientaçào durante as etapas desta pesquisa.

À Mônica Nunes e Laura Roizman pelo constante incentivo, sobretudo nos momentos mais tensos.

Aos colegas da revista Ecologia e Desenvolvimento. especialmente à Beatriz Bissio, pelos ensinamentos e contribuição fundamentais para meu crescimento profissional.

Ao Professor Lennart Sjöberg, diretor do Center for Risk Research - Stockholm School of Economics. pelas sugestðes e receptividade.

Aos pesquisadores do Center for Risk Research - Stockholm School of Economics. em especial ao pesquisador Mattias Viklund pelas ricas discussões e sugestões constantes e à secretária Caroline Nordlund pelo simpático auxilio durante minha estada naquela cidade.

Ao Professor Achim Schrader, do Latemamerika Zentrum der Westfalischen Withems - Universität Münster. pela receptividade e pelo auxilio durante minha visita aquela universidade.

A Heiner Pott. do Umweltschutz-Munster. pela oportunidade do debate e pelas ricas sugestões. .

Ao colegas e professores do Instituto Goethe. em especial. a Gunter Kipfimuller pelo apoio e confiança em meu trabalho.

A Associação dos Ex-bolsistas da Alemanha. sobretudo a Orlando Sabino pelo incentivo e apoio constantes.

Aos funcionários da Cetesb. especialmente as bibliotecárias pelo auxilio durante o levantamento de dados.

Às funcionárias da Seção de Pós-(iraduação da FSP. em especial à Ângela. Silvia. Marilene. Cidinha e Renilda que. com muita disposiçào e sensibilidade, tornaram mais branda a burocracia acadèmica.

Aos meus irmãos pelo carinho, apoio e paciência constantes.

Aos meus sobrinhos pelo carinho e pela alegria freqüentemente transmitidos.

A todos os meus velhos e novos amigos pela contribuição, direta ou indireta. para a realização deste trabalho e pela compreensão de minha longa ausência.

Ao amigo Edmilson Silva pela presença e apoio durante todo o desenvolvimento deste estudo.

Aos meus alunos, novos e antigos. por poder fazer parte de seus sonhos.

Ao Mauricio Fiaschetti pelo carinho e sensibilidade durante a etapa final desta pesquisa.

Ao Conselho Nacional de Desenvolvimento Cientifico e Tecnológico - CNPq pelo apoio financeiro. 


\section{RESUMO}

Silva. CV. Comunicação de Riscos Ambientais - uma ferramenta para a tomada de decisão. Estudo de caso: projeto de incineração de resíduos sólidos domiciliares para a cidade de São Paulo. São Paulo: 2001. |Tese de Doutorado - Faculdade de Saúde Pública da USP]

Objetivo. Identificar a Audiência Pública e os meios de comunicaçào como duas possíveis ferramentas de comunicação de riscos. Métodos. Selecionou-se um projeto de instalação de usinas de incineração na cidade de São Paulo como estudo de caso. Para a análise dos fenômenos comunicacionais do caso em questão. desenvolveu-se um estudo da Audiência Pública. na qual foi apresentado o EIA/RIMA do incinerador. e das reportagens publicadas nos jornais Diário Popular e Folha de S.Paulo no periodo de 1994 a 2000 . Resultados. O estudo da Audiência Pública revelou alguns obstáculos para o desenvolvimento de um processo de comunicação capaz de auxiliar na democratização da tomada de decisão. Entre essas barreiras pode-se destacar a falta de credibilidade das informaçoes transmitidas pelas diversas fontes. a estrutura anti-democrática da Audiencia a a demanda de informações técnicas sobre o empreendimento. A análise das reportagens registrou a propagação de rumores. a utilização das mesmas fontes de informação e uma cobertura apenas pontual. Conclusões. A Audiência Pública e os meios de comunicação podem auxiliar no processo de democratização da tomada de decisão, no entanto. a partir de uma avaliaçào crítica dos principais obstáculos para sua efetiva utilização. Se a comunicação de riscos for legitimada pelas autoridades ambientais. o passo seguinte tende a compreender a Audiência Pública e a atuação dos meios de comunicação como suas principais ferramentas. permitindo com isso que sua utilização formal minimize a manipulação que interfere no desenvolvimento do diálogo e na participação de todos atores sociais na tomada de decisão.

Descritores: incineração de residuos sólidos. comunicação de riscos ambientais. meios de comunicação. percepção de riscos ambientais. 


\section{SUMMARY}

\section{Silva. CV. Environmental Risks Communication - a tool for decision-making. Case : project of incineration of residential solid residues for São Paulo town. São Paulo; 2001. [Tese de Doutorado - Faculdade de Saúde Pública da USP]}

Objective. Identify the Audience and the media as too possible risk communication tools. Methods. A project of installation of incineration areas was selected as case. To analisy the communicational phenomena of the metioned case, a study on Audience was developed, in which was presented EIA/RIMA of the incineration and the articles published in the news papers Diário Popular and Folha de S.Paulo from 1994 through 2000. Results. The study on Audience showed some obstacles to development of communication process capable of helping with the establishiment of the democratization in decision-making. Among these obstacles we can stand out the credibility of information transmitted by several sources. the anti-democratic structure of the Audience and the call for technical information about the undertaking. The articles analysis showed the rumors spread. the use of the same information sources and a merely punctual coverage. Conclusions. The Audience and the media can help with the democratization in the decision-making process, however. from a critical assessment of the main obstacles to its effective use. If risk communication is legitimated by environmental authorities the next step may understand the Audience and the media as its main tools. making its formal use minimise the manipulation that interferes in the dialog the development and the participation of all social activists in the decision-making.

Descriptors. Solid residues incineration. Environmental risk communication. Media. Environmental risk perception. 


\section{ÍNDICE}

1 - INTRODUÇÃO

\section{1}

1.1 - Objetivos 6

1.1.1 - Objetivo Geral 6

1.1.2 - Objetivos Especiticos 6

2 - METODOLOGIA 8

2.1 - Hipóteses 8

2.2 - Revisão Bibliográfica $\quad 8$

2.3 - Do Estudo de Caso 10

2.3.1 - Das Audiências Públicas 11

$\begin{array}{ll}2.3 .2 \text { - Da repercussão da midia } & 12\end{array}$

3 - A COMUNICAÇÃO NO CENARIO DOS RISCOS AMBIENTAIS 16

3.1 - Introdução 16

3.2 - Comunicação como Processo Social 17

3.3 - Os Meios de Comunicaçào 26

3.4 - Comunicação de Riscos Ambientais

3.5 - Percepção de Riscos 36

4-RESIDUOS SOLIDOS DOMICILIARES NA CIDADE DE SAO PAULO

4.1 - Introdução +1

4.2 - Classificaçào dos Residuos Sólidos 43

4.3 - Geração de Residuos Sólidos Domiciliares em São Paulo 44

4.4 - Aterros Sanitários $\quad 46$

4.5 - Usinas de Compostagem 49

4.6 - Coleta Seletiva 51

5 - ESTUDO DE CASO -- PROJETO DE INSTALAÇÃO DE USINAS DE INCINERAÇÃO

5.1 - Tecnologia de Incineração $\quad 58$

5.2 - Dioxinas e Furanos 61 
6 - AUDIÊNCIA PÚBLICA COMO INSTRUMENTO DE COMUNICAÇÃO

$\begin{array}{ll}\text { DE RISCOS } & 64\end{array}$

6.1 - Introdução 64

6.2 - Licenciamento com Avaliação de Impacto Ambiental 65

6.3-Audiência Pública na Legislação Ambiental 71

6.4 - Análise da Audiència Pública - incinerador de Sapopemba 73

6.4.1 - Da Estrutura e Dinâmica 73

6.4.2 - A Abordagem no Discurso dos Atores Sociais 75

6.5 - Análise dos Resultados 91

7 - ANÁLISE DAS REPORTAGENS 97

7.1 - Introdução 97

7.2 - A Produção de Noticias nos Jornais Diário Popular e Folha de S.Paulo 98

$\begin{array}{ll}7.3 \text { - Fontes de Informaçào } & 100\end{array}$

$\begin{array}{ll}7.4-\text { Assuntos Abordados } & 104\end{array}$

$\begin{array}{ll}7.5-\text { Análise dos Resultados } & 110\end{array}$

8 - CONCLUSÕES 114

8.1 - Recomendaçòes 120

9 - REFERENCIAS

ANEXOS

Anexo 1 - Cópia das matérias selecionadas no jornal Diário Popular

Anexo 2 - I evantamento de fontes por matéria publicada no jornal Diário Popular

Anexo 3 - Cópia das matérias selecionadas no jornal Folha de S.Paulo

Anexo t - Levantamento de fontes por matéria publicada no jornal Folha de S.Paulo 


\section{LISTA DE TABELAS}

Tabela 1 - Aterros sanitários em operação

Tabela 2 - Aterros sanitários em manutenção $\quad 48$

Tabela 3 - Aterro sanitário em fase de recuperação ambiental $\quad 48$

Tabela 4 - Usinas de Compostagem em Operação 50

Tabela 5 - Composição média em peso do resíduo proveniente da coleta seletiva 52

Tabela 6 - Consumo de energia para processamento de matéria prima virgem e de $\begin{array}{ll}\text { matéria reciclada } & 54\end{array}$

Tabela 7 - Metodologias para calcular o ganho com a reciclagem. no contexto da coleta seletiva $\quad 54$

Tabela 8 - Estrutra e dinàmica de uma Audiência Pública 72

Tabela 9 - Estrutura e dinâmica da Audiência Pública sobre o incinerador de Sapopemba

Tabela 10 - Produção de matérias nos jornais Diário Popular e Folha de S.Paulo sobre a instalação de incineradores de residuos domiciliares na cidade de São Paulo

Tabela 11 - Incidencia dos grupos de fontes de intormação no total das matérias pesquisadas

Tabela 12 - Citação dos três blocos de fontes nas matérias pesquisadas

Tabela 13 - Incidencia das informações mais complexas

Tabela 14 - Classificaçào, origem e tratamento das fontes de informações no jornal Folha de S.Paulo

Tabela 15-Quantidade de grupos de fontes por matérias pesquisadas 


\title{
LISTA DE SIGLAS
}

\begin{abstract}
ABNT - Associação Brasileira de Normas Técnicas
CADES - Conselho Municipal do Meio Ambiente e Desenvolvimento Sustentável

CETESB - Companhia de Tecnologia de Saneamento Ambiental

CONAMA - Conselho Nacional do Meio Ambiente

CONSEMA - Conselho Estadual do Meio Ambiente
\end{abstract}

DAIA - Departamento de Avaliação de Impacto Ambiental

EIA - Estudo de Impacto Ambiental

RAP - Relatório Ambiental Preliminar

RIMA - Relatório de Impacto Ambiental

SMA - Secretaria do Meio Ambiente do Estado de São Paulo

U.S. EPA - U.S. Environmental Protection Agency 


\section{1 - INTRODUÇÃO}

A problemática ambiental vem, ao longo dos anos. tornando-se uma das mais expressivas questões da sociedade contemporânea. Transformada em ciência na segunda metade do século passado, a ecologia ultrapassou fronteiras e aproximou-se mais da realidade das pessoas.

O que parecia distante dos interesses do cidadão comum passou a fazer parte de sua vida. A desertificação do solo, as enchentes provocadas pelo fenômeno El niño, o rodízio de carros, a geração acentuada de resíduos. entre outras questões. excederam aos debates promovidos no ambiente científico e passaram a ser discutidas por outros segmentos da sociedade.

Parte dessa aproximação pode ser atribuida ao trabalho dos meios de comunicação, como rádio. televisão, jornal, revista. cinema. livro etc.. No acompanhamento de alguns acontecimentos verificou-se a importância da difusão. por esses meios, de questões relacionadas ao meio ambiente, possibilitando a formação de uma sociedade educada e conscientizada ambientalmente. além de auxiliar no resgate da cidadania. se for pensado o meio ambiente saudável como um direito adquirido.

Várias experiências. inicialmente positivas. dos meios de comunicação na cobertura de questões ambientais foram e são registradas tanto no Brasil quanto em outros paises.

Essa contribuição pode ser verificada por meio de dois exemplos ocorridos na cidade de São Paulo. a maior metrópole brasileira que, sobretudo. devido a um crescimento desordenado, tem seus problemas ambientais tais como enchentes, produção acentuada de resíduos sólidos domiciliares e industriais. poluição atmosférica ainda mais intensos.

Uma campanha para conscientizar a sociedade sobre a viabilidade e necessidade de despoluição do rio Tietè. de iniciativa da Rádio Eldorado AM, 
registrou a importancia do trabalho da midia. Em 1990. um programa da Eldorado. produzido em conjunto com a BBC de Londres. levou ao ar. simultaneamente. o relato de dois repórteres. Um. na Inglaterra. navegando no já recuperado rio Tâmisa e o outro aqui no Brasil. sobre o poluido Tietê. A troca de impressóes levada ao vivo pela emissora brasileira conseguiu despertar nos seus ouvintes o desejo de salvar o rio. Milhares de telefonemas. telegramas. cartas de apoio a Rádio com propostas para a despoluição do Tietè foram transmitidos.

A empolgaçào social. causada pela matéria. féz surg̣ir o Núcleo União Pró-Tietê. coordenado pela Fundaçào S.O.S. Mata Atlântica e patrocinado pelo Unibanco Ecologia. com o objetivo de canalizar todo interesse expresso pela população. Esse Nucleo teve como meta inicial realizar um abaixo-assinado com um milhào de assinaturas para mobilizar o governo. Foram conseguidas 1 milhão e 200 mil assinaturas no maior abaixo assinado entào já realizado no Brasil.

() abaixo-assinado e o clima que já envolvia o pais. sede da Conferencia das Nações Unidas sobre Mcio Ambiente e Desenvolvimento - Eco92. pressionaram o governo do Fstado de São Paulo a assumir a recuperação do rio como uma de suas prioridades.

Com certa facilidade. foram aprovados os investimentos internacionais. oficializando assim o Programa de Recuperaçào do Rio liete. conhecido como Projeto Ticte. Já existiam alguns projetos isolados para a recuperaçào do rio. ou relacionados a ele. como obras para controlar as enchentes provocadas por sua cheia, entre outros. muitos deles com resultados quase nulos. Fntão. a mobilização da sociedade. despertada pela reportagem que revelava um rio europeu recuperado de uma poluição semelhante ao do rio Tietê. veio contribuir para que o problema fosse definitivamente reconhecido pelos órgãos governamentais.

Questòes mais recentes. transformadas periodicamente em midiáticas. como as enchentes na cidade de São Paulo, provocadas por um fenòmeno natural churas torrenciais na estaçào mais quente do ano. intensificadas por problemas de 
escoamento. limpeza pública. manutenção dos bueiros. ruas etc.. são o segundo exemplo.

Vários pontos da cidade sofrem todo verão as conseqüências da inundação. A mídia, por sua vez. capta as imagens necessárias para a comoção em massa. O desespero das vitimas, causado pelos danos materiais e pessoais, tem sido um dos elementos chaves para o aumento da audiència. Vítimas e heróis são apresentados em programas de auditório para transmitirem suas experièncias.

No entanto. passados poucos meses de uma situação considerada insustentável para a cidade. os meios de comunicação. a população e as autoridades competentes parecem esquecer tais imagens ou, pelo que indica. subestimar sua importância.

Esses dois casos sugerem. por um lado, a importância da veiculação de questões ambientais pelos meios de comunicação. Pois. é por meio de jornais, rádio ou televisão que determinada comunidade fica sabendo desses problemas. Por outro lado. reforçam a idéia de que as reportagens sobre meio ambiente. na maioria das vezes. conseguem emocionar mais do que informar corretamente as pessoas. Elas despertam no público sentimentos de revolta. vontade de mudar. emoção. Isso. em parte. deve-se à estreita relação entre os impactos ambientais e o comprometimento da qualidade de vida. No entanto, verifica-se que a reação da sociedade é muitas vezes efêmera e que a função dos meios de comunicaçào não parece exceder a espetacularização da realidade.

A escolha pela comunicação de riscos como objeto de estudo desta pesquisa está fundamentada em sua importância para o desenvolvimento de uma politica de tomada de decisão mais democrática e participativa em relação ao atual modelo, no qual a comunicação tem sido. não regularmente. utilizada.

A elaboração de um processo de comunicação ético. democrático que, por mais utópico que pareça, não vise à manipulação da opinião pública, tem sido o 
grande desafio para os diversos setores envolvidos em determinadas situações de gerenciamento de riscos.

A comunicação tem se revelado. em diversas áreas. como um instrumento poderoso. no entanto. dependendo dos interesses em questão pode trazer sérias conseqüências à sociedade. Se por um lado a comunicação tem se tornado um instrumento eficaz, por exemplo. nas campanhas públicas de vacinação. tem em outros casos apenas intensificado a polêmica existente e pouco contribuido para a minimização dos danos ambientais ou dos impactos à saúde da população.

$\mathrm{Na}$ área científica e especialmente ambiental. a disseminação de rumores tanto pela midia quanto pelos atores envolvidos no processo direto de comunicação tem sido uma das impossibilidades para a busca de soluções conjuntas. As simplificaçòes de informaçòes científicas ou suas interpretações como. por exemplo. "tal substância mata". " "é carcinogènica. independente da dose-exposição". incrementam os desatios para um processo de comunicação equilibrado.

A escolha por uma pesquisa sobre as funções. importância e papel social da comunicação de riscos. no processo de tomada de decisão. deve-se à constatação de uma literatura nacional ainda incipiente sobre o tema. Outro fator determinante são os indicios que apontam para o uso. na prática. da comunicação como um instrumento de manipulação que garanta a aceitação ou a rejeição do risco por determinada comunidade em detrimento à promoção de sua real participação no processo decisório.

A elaboração de uma discussão conceitual. fundamentada com um estudo de caso. visa a interpretar a comunicação de riscos com base na realidade social, cultural. econòmica. ciêntifica e política brasileira. ou seja. a considerar as especificidades nacionais. que muitas vezes são deixadas em segundo plano quando são adotados modelos de políticas de gerenciamento de riscos elaboradas nos países desenvolvidos e para a realidade dos mesmos. 
O caso dos incineradores de residuos domiciliares justifica a necessidade do envolvimento multissetorial dos diversos segmentos da sociedade. já que o problema da geração de resíduos sólidos domiciliares é de responsabilidade de todos os cidadãos e um problema de saúde pública. Seu estudo viabiliza ainda verificar quando e como a comunicação é incorporada ou adaptada pelo licenciamento ambiental e quais as ferramentas disponiveis para sua aplicaçào.

Um exemplo de licenciamento de uma usina de incineração. apesar de destinada a resíduos perigosos. pode ilustrar os desafios mais comuns do processo de tomada de decisão. Stern e Fineberg (1996) comentam sobre o trâmite de licenciamento de uma usina de incineração de resíduos perigosos no Leste de Liverpool. em Ohio, entre 1990 e 1992. Segundo os autores. foram realizados pelos órgãos competentes todos os procedimentos téoricos previstos na legislação ambiental. assim como análises dos riscos potenciais. No entanto. a comunidade. em especial a mais suscetivel aos impactos da planta. demonstrou sua posição frente ao que identificou como um processo para aprovação de algo que já estava claramente aprovado pelas autoridades. Isso significa que a exclusão da comunidade do processo de tomada de decisão poderia ser evitado caso houvesse de fato um programa de comunicação horizontalizado. permitindo assim a participaçào efetiva dos diversos atores sociais.

Dos instrumentos utilizados para a elaboração de um programa de comunicação de riscos. o acesso à informação recebe destaque. Porém. deve-se considerar quais as formas encontradas pela população para acessar tais informações.

A pesquisa $O$ que o Brasileiro Pensa da Ecologia revelou que a maneira mais utilizada pelo público para obter informações sobre a temática ambiental é por meio da TV e dos jornais. A TV apresentou maiores índices. $65 \%$. e os jornais $28 \%$. porém os índices estão associados a programas convencionais e não a especializados (Crespo \& Leitão, 1993). 
Quando questionados sobre a credibilidade dos meios de comunicação de massa. 57\% dos entrevistados tizeram uma avaliação positiva (Crespo \& Leitão. 1993). Isso conota uma relação de contiabilidade entre o público e os meios de comunicação de massa.

A partir dos dados revelados por essa pesquisa. em um dos mais importantes trabalhos de identificação da relação entre a sociedade brasileira e os temas ambientais, verifica-se a importância de uma análise do conteúdo disseminado por esses veículos de comunicação. da credibilidade das principais fontes utilizadas nas reportagens. da credibilidade da informação e da geração de contlitos entre outras observaçòes.

\section{1 - Objetivos}

\subsection{1 - Objetivo Geral}

Identificar a audiencia pública e os meios de comunicação como duas possiveis ferramentas de comunicaçào de riscos.

\subsection{Objetivos Especificos}

O estudo especifico desta tese tem como metas:

- desenvolver uma discussão sobre o conceito de comunicação de riscos. visando a minimizar os equívocos conceituais mais comuns. como por exemplo. sua interpretação como mera tradução de informações técnicas do especialista para o leigo: 
- identificar os principais desafios para o desenvolvimento de uma comunicação de riscos efetiva e apontar possiveis caminhos para amenizálos:

- por meio de um estudo de caso. identificar e analisar a Audiência Pública e os meios de comunicação como possíveis ferramentas da comunicação de riscos. 


\section{2 - METODOLOGIA}

\section{1 - Hipóteses}

Para melhor fomentar o debate e alcançar os objetivos deste estudo. foram elaboradas três hipóteses que serão analisadas no decorrer da pesquisa.

HI: a comunicação de riscos ambientais é comumente interpretada como mera transmissão e tradução de informações técnicas de um público de especialistas para um de não especialistas:

H2: os principais desatios para uma politica eficaz de comunicação de riscos sào a falta de credibilidade entre os atores sociais envolvidos no processo comunicacional e o conflito entre a percepção ou a posição de cada um desses atores em relação aos riscos:

H3: a audiência pública e os meios de comunicação podem ser duas importantes ferramentas auxiliares para a democratização do processo de tomada de decisão.

\section{2 - Revisão Bibliográfica}

O levantamento bibliográfico foi realizado. em sua maior parte. durante estágio no Departamento de Saúde Ambiental da Faculdade de Saúde Pública entre os anos de 1998 e 1999.

De dezembro de 1999 a janeiro de 2000. foi realizada outra parte significativa da revisão bibliográfica durante visita ao Centro de Estudos de Riscos. da Faculdade de Economia de Estocolmo. na Suécia. 
A visita a esse centro de pesquisa permitiu o acesso a uma vasta produção científica, especialmente na área de comunicação e percepção de riscos. A pesquisa bibliográfica foi somada a troca de informação com o grupo multidisciplinar de pesquisadores daquele Centro.

Desta forma, foi constatada a existência de um vasto material bibliográfico na área de comunicação de riscos, no entanto. não houve registro de literatura nacional a respeito da temática. Parte relevante desse material tem origem nos Estados Unidos e foi produzida em diversos centros como Center for Environmental Communication. da Universidade de Rutgers, no Risk Analisys Center e Environmental Protection Agency. Alguns paises europeus, em especial Suécia e Alemanha. também possuem uma literatura significativa na área. tendo destaque a questão da percepção de riscos e o papel social dos meios de comunicação naqueles paises.

Deve-se ainda registrar a visita ao Centro de Estudos Ambientais da Universidade de Münster. Alemanha, no período de janeiro a fevereiro de 1999. Como parte integrante dessa visita. foi desenvolvido ainda um processo de observação das estratégias utilizadas pelos agentes ambientais daquela cidade para tornar a problemática ambiental uma questão mais próxima da realidade de seus cidadãos e assim poder integrá-los ao debate.

Vale ressaltar que a bibliografia estrangeira foi significativamente importante para a realização desta pesquisa. no entanto. percebe-se uma distância entre a realidade apresentada nessas publicações e a situação no Brasil. Assim. muitos dos estudos acessados podem subsidiar a elaboração de uma política de comunicação de riscos, desde que sejam consideradas as especificidades brasileiras.

A revisão bibliográfica teve como objetivos principais: a) caracterização e conceituação da comunicação de risco; b) conhecimento científico da comunicação como um processo social complexo excedente às 
funções dos meios de comunicação: c) conhecimento de metodologias de análise para a identificação do modelo ou perfil da comunicação de riscos presente no caso estudado.

\section{3 - Do Estudo de Caso}

Devido à complexidade que envolve um processo de comunicação. sobretudo de riscos ambientais. decidiu-se estudar um caso que melhor representasse a problemática ambiental. ou seja. uma questão multifacetada. com suas implicaçoes econòmicas. políticas. sociais. culturais e cientificas.

Parte da bibliogratia consultada na área de comunicação de riscos apresenta a problematica dos residuos sólidos e as tecnologias de disposição final como exemplos de contlitantes processos de tomada de decisào. Ao considerar a importancia de compreender a intensificação do problema dos residuos sólidos. especialmente nas grandes cidades. sob o ponto de vista comunicacional. optou-se por estudar a proposta da Prefeitura de São Paulo que visava a instalação de dois incineradores de residuos sólidos domiciliares como forma de equacionar o problema.

Além de corresponder a um exemplo comum na bibliografia estudada. a escolha desse caso também está associada à experiència jornalística na area de meio ambiente. possibilitando a oportunidade de assistir às duas audièncias públicas. previstas na licença ambiental dos dois projetos do municipio.

O acompanhamento desse projeto da Secretaria do Verce e do Meio Ambiente de São Paulo, ainda como jornalista. viabilizou a identificação de um vasto material para análise. especialmente no que diz respeito à comunicação. 
Para então analisar $o$ aspecto comunicacional da proposta da Prefeitura de São Paulo, a instalação de duas usinas de incineração como solução para o problema dos resíduos sólidos, foram escolhidas como objeto de análise as Audiência Públicas e a repercussão do projeto nos meios de comunicação.

\subsection{1 - Das Audiências Públicas}

O projeto da Prefeitura, apresentado no Capitulo 5, previa a instalação inicial de dois incineradores, empreendimento que demanda Estudo de Impacto Ambiental - EIA, como um dos procedimentos previstos para a obtenção da licença ambiental. descritos na Resolução SMA 42/94.

Outro procedimento adotado. presente na mesma Resolução, foi a realização de Audiências Públicas para apresentar e debater com a sociedade os resultados do EIA/RIMA.

Por tratar-se de duas instalações diferentes, uma para o bairro de Santo Amaro e a outra para Sapopemba, ou seja. de dois processos distintos de licenciamento, houve então duas Audiências.

Devido às semelhanças entre as atividades e discussões envolvendo as duas Audiências Públicas, optou-se pela análise da Audiência que ocorreu em 25 de novembro de 1994, na qual foi apresentado o EIA/RIMA da usina de incineração de Sapopemba.

Ressalta-se que esta pesquisa teve acesso aos dois documentos, mas diante da intensa semelhança, no que diz respeito ao aspecto comunicacional, compreendeu-se pertinente a análise de apenas um deles. 
A Audiência Pública toi analisada por meio de um documento que corresponde ao registro. na integra. do pronunciamento das pessoas presentes na Audiência, contemplando ainda reações como vaias, palmas e risos. Esse material, disponivel ao público na biblioteca da Câmara Municipal de São Paulo e produzido por sua equipe de taquigrafia, não possui paginação e nem foi submetido à revisão. ou seja. trata-se de um registro verossímil da participação dos diversos atores sociais nele identificados.

Esse documento registra ainda o nome das pessoas que manifestaram suas opiniões, idéias e anseios, assim como o nome da instituição a que pertencem. Com esses dados foi possivel identificar os principais atores e representações sociais presentes no debate.

Compreende-se. nesta pesquisa. a comunicação desenvolvida durante a Audiência Pública como um processo primário. ou seja. sem a interferência dos meios de comunicação, viabilizando assim o contato direto entre os principais atores envolvidos. tais como representantes da comunidade do entorno do empreendimento. de órgàos de controle ambiental. Cetesb. Consema. Secretaria do Verde e do Meio Ambiente. Secretaria Estadual do Meio Ambiente. parlamentares. Organizações Não Governamentais entre outros.

\subsection{2 - Da Repercussão na Mídia}

$O$ projeto da Prefeitura tornou-se público no final de 1993 com o processo de licitação de empresas interessadas no empreendimento. No entanto. o objeto desta pesquisa é compreendido a partir de 1994. ano em que são realizados os Estudos de Impacto Ambiental e conseqüentemente a divulgacão de seus respectivos Relatórios de Impacto Ambiental para a obtenção das licenças de instalação e de operação. 
Foi então considerado, para a coleta do material jornalístico. o período de 1994 a 2000.

A coleta desse material foi, inicialmente, realizada nos arquivos de dois jornais de maior circulação em São Paulo, a Folha de S. Paulo e O Estado de S. Paulo. A busca, no primeiro momento, utilizou os recursos da Internet, rede mundial de computadores. na qual ambos jornais disponibilizam na íntegra. exceto fotografias e figuras. as matérias neles publicadas.

No decorrer da pesquisa. no entanto, identificou-se que tanto a quantidade de matérias publicadas nos dois jornais quanto o tipo de abordagem apresentavam consideráveis semelhanças. Desta forma, para melhor equilibrar o estudo fez-se a opção pela análise de dois veículos com público mais diversificado, gerando consequentemente uma abordagem diferenciada. Para este estudo foram escolhidas as matérias publicadas na Folha de S. Paulo e no Diário Popular.

Antes de apresentar o critério para a escolha dos jornais, apresenta-se a seguir o procedimento utilizado para a coleta das matérias publicadas nos dois veículos de comunicação.

Este estudo chamou de matéria todas as peças jornalísticas, ou seja. noticias, notas, reportagens. entrevistas. editoriais. comentários. artigos. resenhas e crònicas

A busca das matérias foi feita no clipping da Cetesb, desenvolvido por sua Assessoria de Comunicação e disponibilizado para consulta pública. Esse clipping é composto por matérias que abordam a temática ambiental e abrange os principais jornais impressos.

Para garantir precisão na busca desse material foi feita a coleta também no banco de dados da Folha de S.Paulo, trabalho desenvolvido pelos 
profissionais do jornal. seguindo as orientações encaminhadas pela autora desta tese. No Diário Popular a pesquisa foi feita nos arquivos do jornal.

Um outro cruzamento foi realizado na Biblioteca Municipal de São Paulo. que possui excelente acervo da produção desses jornais, boa parte. microtilmado.

A análise de dois jornais impressos tem por finalidade o desenvolvimento de um estudo comparativo, objetivando a identificação de um modelo mais compativel com a cobertura de temas ambientais.

A escolha pelo Diário Popular está fundamentada no perfil de um jornal com abordagem mais popular. que visa a atingir o leitor pertencente às classes econômicas B. C e D. especialmente às duas últimas - critério de classificação da Associação Brasileira dos Institutos de Pesquisa de Mercado (ABIPEME, 2000).

Quanto à escolha pela Folha de S.Paulo, a justificativa está no fato de ser um dos jornais brasileiros de maior circulação e por atingir um leitor aparentemente mais apurado, crítico e exigente. A maior parcela dos leitores da Folha de S.Paulo pertence à classes econòmicas A e B (Folha. 2000).

Outro motivo que levou à escolha da Folha de S.Paulo está associado ao fato de o jornal disponibilizar. por meio da comercialização. seu manual de redação e orientação. A consulta a esse manual registrou. especificamente neste estudo, momentos de conflito entre os preceitos estabelecidos no documento e a atividade prática.

A partir dos procedimentos citados acima foram coletadas 59 matérias, sendo 31 no Diário Popular e 28 na Folha de S.Paulo. no período de 1994 a 1998. Apesar de fazer parte do período pesquisado. entre 1999 e 2000 não houve registro de matérias que correspondessem ao objeto desta pesquisa. 
A coleta considerou as matérias sobre o projeto da Prefeitura ou que, na abordagem de outros temas correlatos, fizeram referência à instalação dos incineradores.

O estudo tanto da Audiência Pública quanto do material jornalístico teve como objetivo identificar a credibilidade das informações transmitidas à comunidade, os rumores mais comuns, os interesses e credibilidade das fontes e dos comunicadores, o papel social dos diversos atores envolvidos com a temática. 


\section{3 - A COMUNICAÇÃO NO CENÁRIO DOS RISCOS AMBIENTAIS}

\section{1 - Introdução}

O processo de comunicação na sociedade contemporânea tem sido comumente interpretado como sinônimo de meios de comunicação. A intensa associação da comunicação à mídia dá origem a alguns equivocos que vão desde a conceituação da comunicação. inclusive no ambiente acadêmico. ao otimismo exacerbado da sociedade em relação às funções desempenhadas pelos veículos de comunicaçào.

Dissociar o processo comunicacional dos veiculos de comunicação é uma tarefa dificil. especialmente. na sociedade moderna que assiste ao acelerado avanço tecnológico. As novas tecnologias têm propiciado o surgimento e aprimoramento de meios e técnicas da comunicação humana capazes de reduzir intensamente as distâncias. Isso possibilita a transmissão de dados e informações às mais distantes regiões do planeta quase em tempo real à ocorrència do fato noticiado.

O meios de comunicação. TV. rádio. cinema. Internet. entre outros. viabilizam e aprimoram a transmissão de informações. por exemplo. entre pessoas. sociedades. nações situadas nos diversos e distantes pontos. No entanto. deve-se compreender melhor sua função no contexto social. considerando seus interesses e operacionalidade.

Neste capitulo, o objetivo principal é revelar a complexidade do fenômeno da comunicação social. assim como da mídia. e suas interfaces com a temática ambiental. especificamente. no contexto do gerenciamento de riscos ambientais. Este objetivo fundamenta-se. sobretudo. nas atribuições feitas à comunicação pelos diversos atores envolvidos no gerenciamento ambiental. sem a ciência e compreensão de seus interesses. complexidades e limitações. 
Desta forma. o capitulo elaborou um debate teórico da comunicação para melhor conduzir uma conceituação e discussão acerca da comunicação de riscos ambientais.

Ressalta-se que esta discussão conceitual da comunicação, tanto em um cenário geral quanto no campo do gerenciamento de riscos ambientais, não tem a pretensão de elucidar os conflitos teóricos. Este momento visa a enfatizar a necessidade de compreender a importância da comunicação como ferramenta fundamental para o processo de tomada de decisão. no cenário ambiental. e de considerar sua atuação na democratização desse processo. sobretudo. nos moldes em que está prevista e estruturada.

Ao considerar a idéia que compreende a comunicação de riscos ambientais resultante do envolvimento de duas disciplinas distintas: estudos da comunicação e estudos de risco (Krimsky \& Plough. 1988). pela complexidade. divergências e imprecisòes cientificas acerca da segunda. optou-se por realizar um estudo que melhor abordasse as questões mais relevantes à comunicação de riscos.

\section{2 - A Comunicação como Processo Social}

Como elemento indissociavel e relevante do processo de comunicação. excepcionalmente na sociedade moderna. os meios de comunicação têm sido objeto de estudo de vários teóricos. pesquisadores de diversas áreas do conhecimento. A preocupação desses estudiosos está fundamentada. sobretudo. nas funções $\mathrm{e}$ interesses sociais desempenhados pela midia. na sua atuação no cotidiano do público e no seu poder. muitas vezes. superestimado.

Torna-se imprescindivel preceder o debate acerca dos meios de comunicação com um resgate da estrutura da comunicação. seu funcionamento, suas complexidades. independente dos veículos utilizados na disseminação de informações e idéias que são parte do objetivo primário de um ato comunicacional. 
Tentar discutir a comunicação centrado. única e exclusivamente. no avanço tecnológico das formas de transmissão de dados, idéias e informações é ignorar a histórica evolução das organizações sociais alcançadas com a comunicação. essencial e inerente à natureza social do homem (Pasquali. 1980).

Algumas correntes teóricas têm sinalizado para a análise do tênômeno da comunicação. no entanto. esses estudos têm priorizado os meios de comunicação, distanciando-se do objetivo principal que é entender o funcionamento de um instrumento essencial para a convivência humana que. para Pasquali (1980), é condição sine qua non para a formação da estrutura social.

Não existe uma definição exata para comunicação. é possível encontrar na literatura uma gama de definições. Pode-se atribuir esse fenômeno ao surgimento recente da comunicação como ciência social. há cerca de 50 anos. No entanto. deve-se ressaltar que parte de suas teorias e pesquisas provêm de outros campos científicos. então já consolidados. como a psicologia. a sociologia. a psicologia social. a antropologia e a ciência política (Diaz. Bordenave. 1986).

Serão apresentadas algumas definições de comunicação humana. ou seja. no contexto de uma organização social. apenas para subsidiar o debate sobre a complexidade da comunicação e mais adiante desse processo social no cenário da problemática ambiental.

Para Diaz Bordenave (1986). comunicação é uma das formas pelas quais os homens se relacionam entre si. com uso de signos. Segundo o autor. o processo visa à comunhão. ou seja. à convergência entre os dois principais elementos que compòem um ato comunicativo: emissor e receptor.

A comunicação humana depende de um fator decisivo que é a compreensão entre os atores envolvidos. No entanto. Penteado (1982) ressalta que compreensão não significa. necessariamente. estar de acordo. $O$ receptor pode compreender o emissor. mas não concordar com suas idéias. por exemplo (Penteado. 1982). 
Essa idéia expressa a atenção demandada para o entendimento do debate sobre a relação entre especialista e leigo. especialmente no cenário ambiental. Muitas pesquisas apontavam para a necessidade da compreensão entre esses dois atores. principalmente quanto à linguagem utilizada pelo primeiro, porém foi possivel identificar que a implicação excedia o fenômeno da compreensão e aproximava-se da constatação de não haver acordo entre as partes, como será discutido adiante.

Segundo Loomis e Beagle apud Diaz Bordenave (1986). comunicação é o processo pelo qual informação. decisões e diretrizes circulam em um sistema social. Esse processo compreende ainda as formas em que o conhecimento. as opiniões e as atitudes são concebidas ou modificadas (Loomis e Beagle apud Diaz Bordenave. 1986).

Para Thompson (1998). comunicação é uma atividade social distinta. na qual ocorrem a produçào. transmissão e recepção de formas simbólicas. utilizando os mais variados tipos de recursos.

Com essas definiçòes. é possível entender o processo comunicacional como um fenòmeno dinàmico. não estático e universal. pois é inerente a toda $\mathrm{e}$ qualquer estrutura organizacional. especialmente. à sociedade humana.

O passo seguinte à conceituação da comunicação é compreender sua estrutura por meio dos elementos que a compõem. Assim como encontra-se na literatura uma série de detinição e caracterização da comunicação. o mesmo ocorre com sua estrutura. seu funcionamento e seus propósitos.

Quanto à estrutura. alguns estudos elaborados. ainda na primeira metade do século XX. por psicólogos e cientistas sociais e políticos. sobre a função da comunicação na sociedade. revelaram que o processo de comunicação tinha início a partir do interesse do emissor. Nesse periodo, a comunicação já deixara de ser definida como mera troca de informação entre emissor e receptor. chamando a atenção para o desnivel na participação desses dois elementos.

Entre esses estudos. destaca-se o do cientista político. Harold Lasswell. de 1948, no qual elaborou um paradigma para identificar a estrutura de 
um processo comunicacional partindo da resposta às perguntas: quem: diz o que: a quem: em que canal: com que efeito?. significando, respectivamente, emissor. mensagem, receptor, meio e feedback (Cohn. 1975).

A contribuição dessa pesquisa de Lasswell também está associada ao fato de ter viabilizado o estudo científico do processo de comunicação por meio da análise de uma ou outra dessas questões. Desta forma. o estudo pode ser dividido em a) análise de controle, parte que estuda o quem los fatores que iniciam e guiam o ato comunicativo): b) análise de conteúdo. de mensagem. que preocupa-se com o diz o que: c) análise dos meios. referente ao em que canal: d) análise de audiência. centrada no a quem: e) análise dos efeitos. ou estudo do impacto sobre as audiências, parte preocupada com o com que éfeito? (Cohn. 1975).

A idéia de Lasswell sugere uma relação entre emissor e receptor. na qual o primeiro tenta exercer controle sobre o segundo. Como observado por inúmeros estudiosos. essa tentativa de manipulação ou de controle é inerente ao processo de comunicação, o que tende a ser ainda mais acentuado no cenário do gerenciamento de riscos ambientais.

O uso dessa divisão de L asswell será importante para a análise dos elementos do processo de comunicação de riscos. objeto deste estudo. No entanto. considera-se relevante a advertència do autor quanto a importancia de se fazer essa análise combinando os elementos entre si. por exemplo. a relação entre emissor e receptor. mensagem e meio. emissor e mensagem etc.. não o fazendo isoladamente.

A figura abaixo revela a estrutura da comunicação. seguindo as idéias de Lasswell:

Figura 1 - Paradigma de Harold Lasswell. elaborado em 1948.

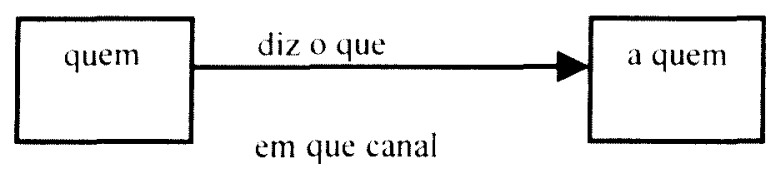


Outros paradigmas foram propostos, além do modelo descritivo de Lasswell. A maioria dos teóricos via a necessidade de inserir mais elementos e de considerar alguns fenomenos. a fïm de constatar o dinamismo e a complexidade do processo, sobretudo, na estrutura de um organismo social.

Segundo Diaz Bordenave (1986), para entender o funcionamento da comunicação deve-se começar pela percepção. Para o autor. dois sujeitos. emissor e receptor. não percebem a realidade da mesma maneira. Isso significa que. cada um possui repertórios diferentes, com suas experièncias, conhecimentos, crenças, valores e atitudes. Possuem ainda repertórios diferentes de signos, que influenciam a percepção (Diaz Bordenave. 1986).

Assim. a percepção da realidade. da mensagem. do emissor pelo receptor e vice-versa passa por um processo de confrontação com os repertórios de cada um. dando origem à interpretação e desta. por sua vez. surge o significado pessoal que cada sujeito atribui ao fato ou objeto percebido. Essa idéia de dinamismo. proposta pelo autor. concede uma estrutura e funcionamento da comunicação. como expostos na figura abaixo:

Figura 2 - Estrutura e dinâmica do processo de comunicação. segundo Diaz Bordenave (1986)

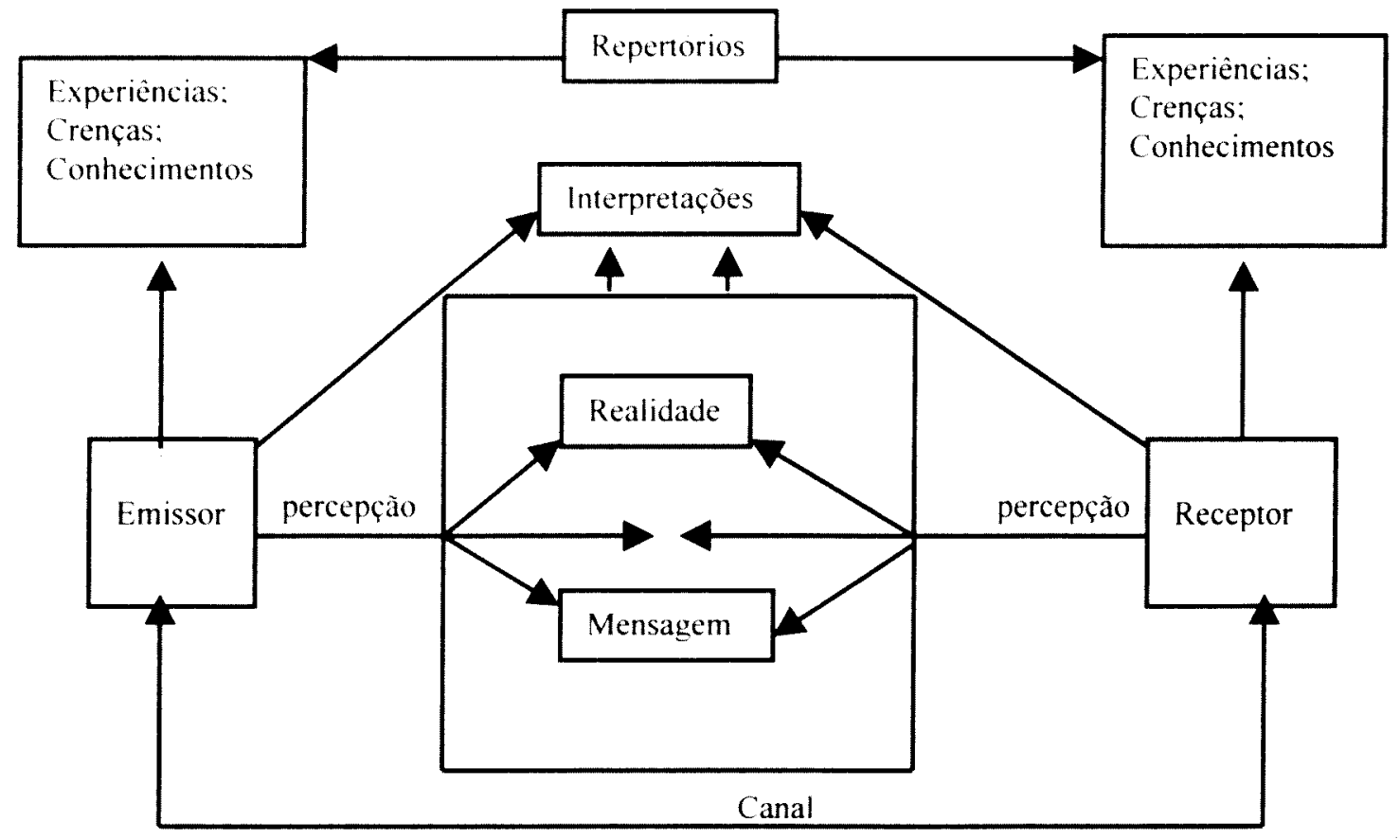


Há uma serie de outros modelos propostos para a identificação da estrutura da comunicação. no entanto. a questão maior não é apenas definir sua estrutura. mas sim compreender sua dinàmica.

Alguns estudiosos latino-americanos. representantes da corrente teórica denominada Teoria Hegemônica. compreendem como maior desafio a horizontalidade do processo comunicacional. abandonando de vez a verticalidade que. segundo eles. teve origem no modelo aristotélico do discurso (Barbero. 1987).

No sistema vertical. o emissor encontra-se sempre em condição privilegiada e dominante em relação ao receptor. enquanto que a proposta horizontal compreende um receptor mais ativo e crítico. não permitindo por sua vez a manipulação e controle que são. para muitos estudiosos do assunto. o objetivo maior da comunicaçào.

No entanto. torna-se necessário ressaltar que esse controle nem sempre causa efeitos negativos ao receptor ou a sociedade como um todo. As campanhas de comunicaçào em saúde publica podem ilustrar bem esse fato.

A campanha do Ministério da Saúde. por exemplo. solicitando às mães que levassem seus tilhos para tomar a dose da multi-racinação e o sucesso verificado a partir da adesào é um exemplo de que o controle. exercido pelo emissor sobre o receptor. nem sempre é negativo.

Esse controle não acontece com tanta facilidade. assim como o receptor nào é vitima freqüente do emissor. Recorre-se a duas perguntas para melhor compreender o fenòmeno do controle e consequentemente do efeito na comunicação: Por que outras campanhas. por exemplo. sobre o racionamento de água nào têm tido o mesmo sucesso? E o que auxilia o sucesso da campanha de multi-vacinação?

Ambas as respostas demandam uma pesquisa mais aprofundada. porém. é possivel com os dois exemplos identificar outros elementos fundamentais que compõem a dinâmica da comunicação. dentre eles a predisposição. Pode-se chegar aos indícios de que as mães. receptoras da 
mensagem de vacinação. para não terem seus filhos vitimas de certas enfermidades, estão predispostas à mensagem, a partir da evidência de que o conteúdo transmitido pela fonte diz respeito diretamente à sua vida e de sua familia.

Quanto ao racionamento da água. há indícios de distanciamento em relação à mensagem. pois a água no Brasil é tratada como um recurso natural abundante e infinito, pensamento que prejudica a percepção do receptor de um problema próximo de sua realidade.

A predisposição não é inerente apenas à relação receptor-mensagem. Ela ocorre também nas relações receptor-emissor. quando a audiência está predisposta a dar atenção a um determinado emissor e assim iniciar um processo de comunicação. Essa atenção. por sua vez. está associada à imagem positiva do emissor em relação ao receptor.

Um estudo de Berelson e Steiner (1964). sobre o que chamou de indiferença do receptor. amplia a ocorrència da predisposição na comunicação e. assim como o trabalho de Diaz Bordenave. auxilia na compreensão da dinâmica desse processo social. Os seis tópicos mencionados a seguir foram extraidos desse estudo de Berelson e Steiner:

- As pessoas tendem a ver e a ouvir as mensagens que são favoráveis às suas predisposiçoes:

- A difusão de rumores é especialmente relacionada à predisposição da audiència:

- As pessoas tendem a perceber mal e interpretar mal a comunicação persuasiva. de acordo com suas próprias predisposições, distorcendo a mensagem num sentido favorável às suas predisposições:

- Quanto maior a confiabilidade. prestígio e credibilidade com que for percebido um comunicador, menos manipulativa será vista a 
sua intervenção e mais imediata a tendência a aceitar as suas conclusoes:

- As comunicações atribuidas a fontes de baixa credibilidade são consideradas mais parciais as comunicaçoes atribuidas a fontes de alta credibilidade.:

- As comunicações têm mais tendência a mudar as opiniões das pessoas que são neutras e menos a afetar as pessoas cujas posições são fortemente reforçadas pelo fato de pertencerem a grupos primários.

A idéia de Berelson possibilita compreender o receptor como o elemento que condiciona a comunicação. Sua indiferença à mensagem e ao emissor. por exemplo. pode provocar a formação de rumores. O rumor é um elemento que demanda atenção especial. a medida em que sua formação e propagaçào interferem diretamente no resultado do processo comunicacional.

Para Penteado (1982). o rumor ou boato circula com intensidade proporcional à importancia e ao desconhecimento do assunto. A origem de rumores, segundo o autor. está associada a algumas causas bem definidas. que são (Penteado. 1982):

- Absoluta falta de noticias autenticas:

- Falha nos sistemas de comunicação:

- Circulação de versóes diferentes sobre o mesmo assunto:

- Falta de contiança na fonte de informação.

No cenário ambiental é possivel registrar uma série de exemplos. Por ser uma questão multifacetada. comumente ocorrem várias versões sobre o mesmo problema. suas causas. soluções etc..

A cobertura jornalística sobre temas ambientais. mais intensamente nos momentos que precederam e sucederam a Rio ${ }^{\circ}$ 2. disseminou rumores que foram transformados em fato verossímil. Por muito tempo a imprensa atribuiu 
importancia à preservação da floresta amazônica pelo fato de ser considerada o pulmão do mundo.

As divergências científicas sobre o esgotamento de recursos naturais não renováveis, o aquecimento global e sobre outros temas possibilitaram o surgimento e propagação de rumores que partiam da comunidade científica. passando pelas redações dos jornais até chegar no cidadão comum.

A discussão sobre os rumores será apresentada adiante. especificamente no contexto do gerenciamento de riscos ambientais.

Deve-se ressaltar. no entanto, que os rumores também exercem influências benéficas. Segundo Penteado, os rumores explicam o desconhecido, o incompreensivel. o secreto. satisfazendo desta maneira o desejo de compreender. Assim. podem ser interpretados como tentativa e necessidade de se ter acesso a determinada informação (Penteado. 1982).

A dinàmica do processo de comunicação não é ameaçada apenas pelo surgimento de rumores. especialmente associados à mensagem e à fonte de informação. A comunicação também está suscetivel ao aparecimento de ruídos.

Ruídos são considerados interferências no processo de comunicação. Wrigth (1975) acentua três principais tipos de ruidos: o semântico. o de canal e o ideológico.

O ruído semântico está associado à mensagem. quando, por exemplo, o emissor faz uso de códigos que não compõem o repertório do receptor ou quando um termo excede seu significado denotativo.

A interferència de canal corresponde à falha na escolha do meio de comunicação entre o emissor e o receptor. O avanço do uso doméstico do computador nos dias atuais e com isso a idéia da Internet grátis gera uma visão equivocada de que todos têm acesso às informações disponibilizadas pela rede de computadores. Uma instituição que prioriza o acesso a suas informações via um computador. esquece-se de uma realidade social que encontra-se aquém desse meio, provocando desta forma um ruído de canal. 
O ruido ideológico, referente a imagem do emissor sobre o receptor e vice-versa. registra uma das principais interferências para a efetividade da comunicação social. Se a imagem do emissor for negativa diante do receptor de sua mensagem. esta por sua vez também será negativa. ou seja. para o receptor a informação estará comprometida com os interesses desta fonte de baixa credibilidade.

Esses fenómenos da comunicação serão resgatados para a análise do estudo de caso proposto. porém já no cenário ambiental. mais especificamente no contexto dos riscos ambientais.

Se a estrutura e a dinâmica da comunicação já conotam sua complexidade. a utilização dos meios de comunicação. como canal entre emissor e receptor. torna o efeito desse tenomeno ainda mais imprevisivel.

\section{3 - Os meios de Comunicação}

Os meios de comunicação. cinema. TV. rádio, jornal. revista. livro atc.. tèm recebido atençào de vários estudiosos da comunicação. Para a maioria deles. é imprescindivel discutir sobre o papel social desses veiculos e o interesse daqueles que os operam.

Como citado na introdução deste capítulo. tem sido freqüente entender a comunicação pela ótica dos meios de comunicação. Quando discute-se a importància da comunicaçào. em um determinado contexto. tende-se a interpretála como o trabalho da midia. sobretudo. a cobertura jornalística. os programas educativos etc..

No cenário ambiental não é diferente. Um dos exemplos é a tentativa de revelar para a sociedade a importância da aplicação dos preceitos sócioambientais da Agenda 21. Para algumas $O N G$ 's. políticos. entre outros. isso é um problema de comunicação. no entanto. estão se referindo ao papel exercido pelos meios de comunicação. 
Essa atribuição de responsabilidades à mídia denota desconhecimento da dinâmica desses veículos. ou seja, de como as pautas são formuladas, a quais interesses a mídia atende e quais são suas reais funções na sociedade. ou melhor. como têm sido desempenhadas.

Para Eco (1998). primeiro é necessário entender que os meios de comunicação podem ser utilizados para o bem ou para o mal. Desta forma. ao tratar das funções e importância social da mídia. o autor chama a atenção para algumas conseqüências positivas e negativas para a sociedade.

Das idéias de Eco. destacam-se como positivos:

- os meios de comunicação possibilitarem acesso à informação a pessoas de variadas camadas sociais:

- a quantidade de informação recebida é necessariamente transformada em qualidade: os individuos tendem a selecionar as mensagens que recebem:

- a grande quantidade de informação sensibiliza o homem contemporâneo para o engajamento. para a participação no cotidiano.

Como aspectos negativos:

- o público da midia sofre sua influência inconscientemente. não tendo aparato crítico para julgar aquilo que percebe:

- as emoções provocadas pela mídia são intensas e imediatas:

- os meios de comunicação estão sujeitos à lei da oferta e procura.

Segundo Willen (1997), a grande quantidade de dados. disponibilizada tanto pelos meios de comunicação convencionais quanto pela denominada nova midia. como a Internet. é erroneamente interpretada como informação. Para Willen há um conflito conceitual entre disponibilização de dados, informação e aquisição de conhecimento. Os elementos dessa triade encontram-se. na verdade. dissociados entre si (Willen. 1997). 
A utilização desses canais de comunicação entre emissor e receptor tem gerado outro debate sobre o que se passou a chamar de comunicação de massa.

A comunicação de massa. definida por alguns teóricos como um tipo de comunicação realizada via o uso de um meio massivo de comunicação, tem excedido essa definição. Para Wrigth (1975) o que caracteriza a comunicação de massa é a natureza de très dos elementos que compõem um processo comunicacional. Segundo o autor. na comunicação de massa o receptor é grande. heterogêneo e anônimo. A mensagem é rápida. pública e transitória. E por último. o emissor é aquele que está ligado a uma estrutura organizacional. como um newsmaker.

A conjugação da natureza desses clementos auxilia na compreensão de alguns dos fenômenos provocados pela comunicação massiva. Porém. é necessário compreender melhor tais caracteristicas. O fato do receptor ser grande significa um número de pessoas suficientes para provocar uma relação de anonimato entre este co emissor e é heterogêneo porque alcança diversos públicos ao mesmo tempo. Quanto ao perfil da mensagem. verifica-se que ela tem de ser rápida para favorecer o aparecimento de outras. tornando-se transitória. Por último a mensagem é pública. não endereçada a ninguém (Wright. 1975).

Parte dessas caracteristicas apontadas por Eco e Wright constitui o processo que envolveu os dois exemplos citados na Introdução desta pesquisa. No momento das reportagens a população se sensibilizou. expressou seu repúdio. cobrou explicações das autoridades. No entanto. passado o efeito provocado pela cobertura da imprensa. pouco tem se falado a respeito do Projeto Tietê ou das enchentes de verão. Esse fenômeno pode ser compreendido como uma conseqüência negativa provocada pelos meios de comunicação. As informações foram substituidas por outras, que a cada momento passam a ter maior ou menor relação com o cotidiano das pessoas. identificando com isso uma cobertura jornalística apenas fatual.

Essas observações. fundamentadas em um breve resgate teórico da comunicação e dos meios de comunicação. conduzem a um debate sobre a 
necessidade de entender as limitações e complexidades da comunicação e da midia, sobretudo, no contexto do gerenciamento de riscos ambientais.

\section{4 - Comunicação de Riscos Ambientais}

$\Lambda$ complexidade das questões relacionadas ao meio ambiente. assim como seus impactos para a saúde pública. revela a comunicação como um instrumento fundamental para sua administração.

Em alguns países, a importància da comunicaçào para o gerenciamento de riscos ambientais. por exemplo, já vem sendo observada pelas autoridades. Nos Estados Unidos. o Task Force on Environmental cancer and Hearth and Land Disease. um grupo inter-agencias estabelecido pelo Congresso em 1977. patrocinou uma conferência para discutir o tema. O evento. "O Papel do Governo na Comunicação de Riscos à Saúde e Educação Públicas”. realizado em 1987. identificou o valor da comunicaçào nessa área (Covello e McCallum. 1989).

Esse debate possibilitou a identificação da crescente preocupação do público com os riscos ambientais e de saúde. levando as agèncias governamentais a procurar formas mais adequadas para informar esse público sobre riscos (Covello \& Macc allum. 1989).

Durante esse processo. vários problemas sobre comunicação de riscos foram observados. viabilizando com isso a criação de linhas de orientação para sua melhor adequação. Destaca-se. dentre elas. a necessidade de um modelo de comunicação de riscos que possa ajudar as agências competentes a. por exemplo. reduzir o desnecessário sofrimento humano decorrente da intensa ansiedade, medo e preocupação sobre os riscos (Covello e McCallum. 1989).

Ao resgatar os interesses elementares da comunicação. constata-se a utilização, nesse cenário. de apelos ao medo, de sensacionalismo, da desinformação. por alguns atores sociais. na função de emissores. a fỉm de conquistar o que Bordenave chamou de comunhão. O emissor. na pessoa de um 
representante de uma (ONG. de um órgào de controle ambiental. de um político. empreendedor etc.. tende a usar os mais diversos recursos para convencer a audiència a pensar de acordo com suas crenças. conhecimentos, objetivos.

A audiência. por sua vez. parece em meio a uma produção acentuada de informações das mais variadas sobre o mesmo tema. Em uma situação desta natureza. muito comum na área ambiental. parte por sua complexidade e multidisciplinaridade. o público tende a se posicionar de acordo com suas predisposições. seja à informação. ao emissor ou ao contexto.

Para a realização deste trabalho, tanto a cobertura da mídia quanto a Audiència Pública - como processo tradicional de comunicação. entendido como direto ou face a face. serão considerados e estudados como ferramentas potenciais para o gerenciamento de riscos ambientais e de saúde pública.

No entanto. é necessario discorrer mais sobre o assunto. visando à minimização de atribuiçoes as quais a comunicação ainda não conseguiu cumprir. especialmente no que diz respeito à democratização do processo de tomada de decisiono.

Para alguns autores. quando um jornalista escreve uma história sobre uma substancia química ou um razamento de material radiotivo ele está engajado na comunicação de riscos. Quando a televisão. o cinema. a revista abordam temas tais como um novo medicamento. sobre chuva ácida eles estão comunicando informaçoes sobre riscos (Willis e Okunade. 1997).

Essa comunicaçào. porém. é especial. pois aborda temas polêmicos. com variáveis cientificas. políticas. econômicas. sociais e culturais. Fayard (1988). ao tratar da comunicação científica pública. identificou elementos que auxiliam no entendimento. prévio. do que vem a ser comunicação de riscos. seguido de um estudo sobre seus elementos. suas funções e importância sociais.

Para Fayard. limitar a comunicação científica pública a uma mera transmissão de informações. de dados científicos de um público especialista para um de não especialistas é negar a participação do público no processo decisório. ou pelo menos em parte dele, que aloca recursos provenientes da contribuição 
deste mesmo público para o desenvolvimento do conhecimento científico e tecnológico (Fayard. 1988).

As semelhanças entre o que Fayard entende por comunicação científica pública e a comunicação de riscos. segundo boa parte da literatura estudada. estão fundamentadas no fato do autor entender a primeira como um elemento do crescente debate público sobre os usos das cièncias por grandes complexos industriais. sobre questões da poluição ambiental. aproveitamento de energia atòmica etc.. evidenciando uma necessidade. portanto. das grandes orientações cientificas em ascender a uma certa visibilidade.

Para Gadomska (1994), a comunicação de riscos excedeu à sua definição original em que era interpretada por muitos como uma transmissão de informações de especialistas para o público leigo. Atualmente é considerada em seus vários significados e amplas funções sociais. A autora reforça que a “comunicação de riscos não é. portanto. uma informação unidirecional que resulta daqueles que sabem para aqueles que precisam aprender. mas uma troca de conhecimento. percepçòes. opiniōes e preferências entre os numerosos atores sociais, incluindo o público exposto ao risco e aqueles que o impuseram. os reguladores. especialistas e inspetores de segurança” (Gadomska. 1994, p.147).

Vários autores entendem a comunicação de riscos como uma condição necessária para a realização dos direitos de toda pessoa em participar das tomadas de decisào que dizem respeito à sua vida e saúde. Essa idéia exprime a importância de se resgatar a comunicação para um processo democrático, no entanto. as dificuldades $\mathrm{em}$ viabilizar esse objetivo não são inerentes apenas a essa modalidade de comunicação. como vimos nos tópicos anteriores deste capitulo.

Os problemas ambientais têm se transformado em questões de significativa relevância para a população. levando as autoridades. indústrias e organizações não-governamentais a perceberem a impossibilidade de um gerenciamento ambiental sem um efetivo programa de comunicação (Santos. 1994). 
Essa observaçaio levou as autoridades dos Estados Unidos e de muitos paises europeus, por exemplo, a aprovarem leis que permitissem e garantissem o acesso à informação. Porém. vale ressaltar que parte da demanda para informaçōes ambientais. em um primeiro momento. estava associada à ocorrência de acidentes ambientais tais como Seveso. Bophal. Chernobyl. entre outros (Santos. 1994).

Atualmente essa demanda vai além das tragédias ambientais. Há interesse por informações sobre empreendimentos que possam causar impactos ambientais. regulamentações. leis etc.. No Brasil. essa demanda existe. mas na maioria dos casos representa apenas a comunidade ou as pessoas potencialmente atingidas. não conseguindo. ainda. o envolvimento de uma parcela maior da populaçào.

A discussão sobre politicas, programas ou leis prevendo o acesso a informaçòes sobre riscos ambientais deve ser precedida por uma apresentação conceitual. visando. especialmente. a evitar que a comunicação de risco seja interpretada como sinonimo de acesso à informação.

Vários autores arriscam algumas definições para comunicação de riscos. porém os equirocos tèm sido constantes. Adiante. poderá ser ainda observado que a importância da comunicação de risco não está associada a uma discussào meramente teórica. mas sim de sua possibilidade prática.

Em 1989. O National Research Council publicou um documento no qual define comunicação de risco como "um processo interativo de troca de informação a opiniões entre individuos, grupos e instituições. Ele envolve múltiplas mensagens sobre a natureza do risco e mensagens não estritamente sobre riscos que expressem preocupações, opiniões ou reações às mensagens de riscos ou a planos legais e institucionais de gerenciamento de riscos“" (National Research Council. 1989).

Em um de seus artigos. Santos (1994) faz uso do termo comunicação de riscos para referir-se a um processo que combina o acesso à informação com 
mecanismos de envolvimento do público. À medida em que essas definições de comunicação de riscos são apresentadas. tornam-se mais evidentes as interferências para sua aplicação.

Entre as principais barreiras da comunicação de riscos. a autora destaca a ausência de leis que prevêem. efetivamente o acesso à informação, o receio da perda de controle, a impossibilidade do público para entender as informações técnicas, a apatia do público, a falta de recursos tais como dinheiro, tempo e pessoas e a tradição do não comunicar esse tipo de problemática (Santos, 1994).

Muito antes das primeiras discussões conceituais sobre comunicação de riscos. alguns pesquisadores. diante do processo de comunicação tradicional, já identificavam fatores determinantes de um envolvimento entre emissor e receptor. As idéias de Berelson e Steiner (1964), especificamente sobre a indiferença dos receptores. sua predisposição aos elementos do processo comunicacional, ilustram bem esses fatores.

Segundo Berelson. as pessoas tendem a acompanhar as comunicações favoráveis às suas predisposições. aos seus interesses. Os receptores, quando confiam na fonte. ou seja. em um emissor que tenha credibilidade diante deles. tendem a duvidar da existência de manipulação da informação e mais facilmente aceitam as conclusões dessa fonte de maior prestígio. Isso significa que informações de fontes de baixa credibilidade são consideradas mais duvidosas em relação àquelas de alta credibilidade (Berelson e Steiner, 1964).

Quando essa idéia é importada para o cenário ambiental brasileiro. são constatadas as inúmeras dificuldades às quais um programa de comunicação de riscos está sujeito. Ao analisar a questão da predisposição, entende-se que o acesso à informação ou o envolvimento do público depende. já no primeiro momento, do próprio grau de interesse do receptor em acessar determinada informação ou participar de uma discussão específica. Torna-se necessária uma relação direta entre a questão ambiental e os interesses da audiência. 
Em uma pesquisa realizada no Brasil. em 1991. intitulada "O que o Brasileiro Pensa da Ecologia“, foi constatado o nivel de informaçào do brasileiro em relação ao meio ambiente. Dos entrevistados. $64 \%$ disseram não ter ouvido falar da Conferência das Naçòes Unidas sobre Meio Ambiente e Desenvolvimento - Eco 92 . Porém. o periodo no qual foi realizado o estudo marcou o aparecimento de editorias de meio ambiente nos principais meios de comunicação. Vários jornais. revistas. programas de televisão e rádio criaram espaços para apresentar questões ligadas ao meio ambiente. parte disso em função da Conferência das Nações Unidas que seria sediada no Brasil (Crespo e Leitão. 1993). Essa constatação sugere uma estreita relação entre o acesso à informação. que encontra-se disponivel. e a predisposição do receptor em acessá-la.

Em relação à credibilidade. a pesquisa citada permite uma problematização. Em uma questão sobre o poder da ciència e sua relação com o meio ambiente. o resultado foi surpreendente. Dos entrevistados. $35 \%$ acreditam na capacidade da ciència para resolver problemas ambientais e $36 \%$ não acreditam. Em uma pergunta envolvendo não mais a ciência e sim o cientista. o resultado apresentado foi significativamente distinto. Da amostra. 58\% não acreditam que os cientistas compreendem a realidade ambiental. Apenas $29 \%$ pensam o oposto.

Esse resultado pode auxiliar na compreensão de contlitos. em determinado processo de comunicação de riscos. entre os especialistas e o chamado público leigo. Se a população não acredita ou não confia nos especialistas para resolver questòes ambientais. torna-se difícil uma relação de confiabilidade. credibilidade entre os dois atores. Entende-se ainda que se outras fontes. tais como as organizaçòes não-governamentais. emitirem maior credibilidade para o receptor. por mais manipulativa que seja a informação disseminada por elas. menos o parecerá.

Existe ainda uma série de agravantes para o desenvolvimento de um efetivo processo de comunicação na área ambiental. Em várias pesquisas. presentes na literatura estrangeira. foi constatado o uso. não formal. da comunicação de riscos como um instrumento dos órgãos controladores para 
informar a população de ações já decididas, ou seja. excluindo a população do processo de tomada de decisão. $O$ fato dessa comunidade ser informada sobre os possiveis riscos. por exemplo. de um empreendimento. pode gerar nas autoridades a sensação de compromisso cumprido, e para a população significar sua total exclusão do debate acerca de questões relacionadas a suas vidas.

Essa sensação gera mais conflitos. impossibilitando uma tomada de decisão democraticamente satisfatória. Quando a população percebe que foi excluída do processo, passa a não acreditar na avaliação de riscos e em seu gerenciamento.

Para Sobral (1995), a comunicação tem sido freqüentemente realizada de maneira autoritária e uniderecional. transmitindo apenas informações de riscos dos órgàos competentes ou de empresas e anulando ou reduzindo. com isso, a participação do público.

Outro problema enfrentado por um programa de comunicação de risco está associado a atribuições aos meios de comunicação de massa. Utilizada pelos diversos atores envolvidos na problemática. a mídia revela. no entanto. algumas dificuldades para a cobertura de um tema complexo como é o meio ambiente.

Segundo Nelson (1994), as reportagens sobre meio ambiente exigem dos meios de comunicação uma atenção diferenciada. em especial por sua complexidade e necessidade de enfoque multidisciplinar. e por ser um dos principais meios de informação.

Em seu manual prático para a cobertura de questões ambientais. Nelson (1994) aponta um problema chave para a discussão do papel da mídia na comunicação de riscos. Segundo o autor. "alguns jornalistas ficam intimidados perante as fontes - talvez amedrontados pelos conhecimentos científicos do seu interlocutor. $\mathrm{O}$ resultado é que os jornalistas com freqüência não questionam o suficiente para obter as informações de que necessitam: o significado de um termo técnico. a importância de uma determinada descoberta. a existência ou não de consenso entre os cientistas sobre uma determinada questão"(Nelson, 1994, p.10). 
Soma-se a essa idéia. o fato de os jornalistas procurarem sempre as mesmas fontes, que na maioria dos casos. estão de alguma forma envolvidas com o problema. $O$ uso de fontes neutras poderia minimizar a manipulação da informação sobre riscos. mas como será observado na análise das matérias esse tipo de apuração. de cruzamento não ocorre com freqüência.

Por tratar-se de um conceito relativamente novo. torna-se compreensivel a existência desses desafios, porém. muitos deles datam da identificação da comunicação nas sociedades humanas. Dentre eles, aponta-se a conquista da horizontalidade do processo como o mais dificil de ser alcançado. ou seja. a equidade na participação dos principais elementos envolvidos.

Para que os gestores ambientais considerem a comunicação de riscos como ferramenta fundamental para o processo de tomada de decisão. a comunicação deve deixar de ser um instrumento virtual da política ambiental. viabilizando. com isso. sua aplicabilidade.

Para tentar alcançar uma reflexão sobre conceituação e aplicação de uma comunicação de riscos. excepcionalmente mais próxima da realidade social. politica. economica. cientifica e cultural brasileira. foi adotado o estudo da Audiência Pública e do trabalho desenvolvido pelos dois veículos impressos.

\section{5 - Percepção de Riscos}

Para Tversky e Kahneman (1974) . o resultado de uma interpretação ou de um julgamento sobre determinado fenômeno é frequentemente compreendido como evidência de algo real e concreto. Esse fato leva à formação de fortes preconceitos. que por sua vez interferem na percepção.

O principal ou mais conhecido estudo sobre percepção de risco foi desenvolvido nas décadas de 70 e 80 pelos psicólogos Fischhoff. Slovic e 
Lichtenstein (1978). no qual risco é tratado como um fenòmeno subjetivo e dependente de uma correlação de fatores psicológicos. sociais. instituicionais e culturais.

Sjöberg e Winroth (1986) identificaram que o valor moral das ações. no contexto do gerenciamento dos riscos. faz com que as consequências adversas cresçam. Para os autores. a aceitação de tais ações está fortemente relacionada a seu valor moral.

Comunicação e percepção de riscos são questões complexas. pois a própria definição e compreensão de riscos têm sido objeto de infinitos debates. Há várias definições para riscos e estes são definidos de diferentes maneiras por diferentes pessoas (Covello. 1984).

Segundo Drottz e Sjöberg (1994). em certas pesquisas desenvolvidas foi constatado que algumas pessoas diferenciam o risco pela probabilidade ou pela consequencia. às vezes com a combinação dos dois. Alguns resultados mostraram que aqueles que definem os riscos principalmente como consequência tendem a apresentar os indices dos riscos (Drottz e Sjöberg. 1994).

Nesse estudo foi verificado que as pessoas envolvidas na indústria nuclear. por exemplo. tendem a representar as definiçóes de risco em termo de probabilidade muito mais trequentemente que qualquer outro tipo de grupo de pessoas.

Sjöberg e Drottz alertam para o fato de que pedir às pessoas que classifiquem um risco sem especificar a quem esse risco pertence. é uma prática incorreta. Para os autores. riscos são percebidos de uma maneira diferente. dependendo se eles pertencem à própria pessoa ou a outros indivíduos. Provavelmente os riscos pessoais são levados mais em consideração.

Outra questão importante é que os especialistas classificam os riscos como sendo muito menores do que a forma como o público o faz. Os especialistas 
podem conhecer muito mais do que o público. entretanto. em áreas especificas do conhecimento.

Para Morin (1995), o conhecimento restrito. especializado é uma forma particular de abstraçào. na qual a compreensão de um objeto e sua relação com o seu todo é rejeitada.

Essa idéia de Morin permite compreender alguns motivos pelos quais a relação e a comunicaçào entre o público leigo e o especilista têm sido um desafio importante.

Os especialistas constituem um problema a partir do momento em que subestimam os riscos e são arrogantes para ouvir os argumentos do senso comum sobre as limitações do conhecimento humano e dos problemas psicossociais que estão sempre presentes na implementação das tecnologias (Sjöberg. 1996).

A teoria cultural e o modelo de percepção de risco de Wildavsky e Dake (1990) sugerem que as percepções de risco sejam entendidas como um trabalho funcional. pois as pessoas expressam. em suas percepçòes de riscos. preconceitos culturais que defendem e diferentes modelos de relação social.

As reaçòes das pessoas aos riscos têm se tornado uma questão de central importancia na claboração de políticas de gerenciamento de riscos. Os especialistas raramente concordam entre si e a avaliação dos riscos é incerta. Não e fácil explicar as diferenças entre o conhecimento dos especialistas e do público sobre o mesmo fenòmeno.

Muitos estudos constataram que há uma correlação entre o risco percebido e o conhecimento sobre as questões ligadas àquele risco em particular. A diferença entre um risco percebido pelo especialista e pelo público não demonstra necessariamente uma influência casual na percepção desse risco por decorrência de um alto nível de conhecimento (Sjöberg. 1996). 
Uma politica de comunicação de riscos deve considerar a idéia de que a percepção de risco do especialista raramente é igual a do público e que esse fato conduz à geração de conflitos e de difíceis acordos entre as partes.

No entanto. deve-se compreender que o conflito não ocorre apenas porque os dois grupos de individuos pensam diferente. mas especialmente quando um percebe ou interpreta os interesses do outro.

$\mathrm{Na}$ análise da Audiência Pública esse fenòmeno é visível. Existe a desconfiança da comunidade em relação à fala dos técnicos responsáveis pelo Estudo de Impacto Ambiental. ou seja. de um grupo de especialistas. no entanto. essa mesma comunidade cita outro grupo de especialistas para endossar sua posição contrária.

A falta de um completo conhecimento sobre os riscos pode fomentar o desacordo entre os especialistas. No debate público esse desacordo tende a aumentar. ocorrendo o mesmo com os conflitos. () estabelecimento do conflito social, por sua vez. ganha um formato próprio. um corpo com suas dinâmicas internas.

Essas constataçóes revelam implicaçòes diretas ao processo de comunicação. sobretudo quando o objetivo do processo é o estabelecimento da real participação dos diversos atores e não uma mera aceitaçào das idéias de um determinado grupo.

Segundo Drottz (1991). as realidades politicas e econòmicas influenciam os freqüentes problemas ambientais. assim. os políticos e os governantes temem uma resistència social e uma desaprovação publica referente a essa questāo.

Para a autora. a poluição industrial na União Soviética. por exemplo. tem sido muito mencionada. revelando que a severidade dos problemas atuais parece crescer à medida em que as informações são divulgadas. Constata ainda que embora os acidentes na Three Mile Island e em Chernobyl estejam entre os 
mais graves na concepção do público. essa importância se dá pela cobertura intensiva da midia (Drottz. 1991).

Em comparação interculturais. grandes diferenças foram constatadas quanto ao risco percebido e em relação às preocupações das pessoas. Os estudos de riscos ambientais em diferentes países são de relevància específica. ou seja. dependem dos interesses mútuos em relação ao meio ambiente. Existem razões econòmicas para uma criação de um ambiente limpo e seguro. considerando a situação econòmica nacional e pessoal (Drottz, 1991).

Para este estudo, o aspecto comunicacional. em sua complexidade. é o ponto de partida para compreender melhor o gerenciamento dos problemas ambientais. Segundo Ruesch e Bateson apud Pfromm Netto (1965). comunicação não pode ser interpretada apenas como uma forma de transmitir mensagens verbal, explícita $\mathrm{e}$ intencionalmente. O conceito abriga esses processos, pelos quais as pessoas se influenciam mutuamente. Os autores entendem que "todas as ações ou eventos têm aspectos comunicativos, assim que percebidos por um ser humano: implica. além disso, que tal percepção modifica a informação que o individuo possui e por conseguinte. influencia esse individuo" (Ruesch \& Bateson apud Pfromm Netto. 1965, p.20). 


\section{4 - RESÍDUOS SÓLIDOS DOMICILIARES NA CIDADE DE SÃO PAULO}

\section{1 - Introdução}

A cidade de São Paulo. com cerca de 10 milhões de habitantes (Fundação IBGE, 2000), registra os mais diversos problemas ambientais. como poluição atmosférica. gerada por excesso de veículos automotores e pelas indústrias. enchentes. geração de residuos industriais. domiciliares e de serviços de saúde. habitações irregulares. poluição da água. do solo entre outros.

Esses problemas são intensificados à medida em que a cidade apresenta indices de crescimento desordenado. comprometendo ainda mais a infra-estrutura disponível para. no mínimo, atenuá-los.

Para o desenvolvimento de um debate sobre o processo e as ferramentas de comunicação de riscos ambientais, objetivo principal deste estudo. optou-se pela problemática dos residuos sólidos domiciliares. A escolha por esse problema está fundamentada. especialmente. em sua complexidade e em seu perfil multidisciplinar. inerente ao debate ambiental. I proximidade com a realidade do morador dos grandes centros urbanos. a medida em que todos estão sujeitos a gerar algum tipo de residuo. também foi fator relevante para a escolha do tema.

Para Jacobi (1997). nenhuma outra temática apresenta condições tão favoráveis para o estabelecimento de vinculos entre a atividade humana e o "sistema ecológico“. se não a forma como uma sociedade gerencia o lixo que produz.

Assim. faz-se necessária a modernização dos instrumentos de gestão ambiental, visando a uma engenharia sócio-institucional complexa e democrática. 
calcada em uma estrutura educacional e pedagógica que viabilize o acesso dos diversos atores sociais envolvidos no processo. fundamentalmente dos grupos sociais mais vulneráveis às informações em torno do impacto provocado pelos problemas ambientais (Jacobi, 1997).

Se por um lado a geração de resíduos não parece ser identificada como um problema de meio ambiente e saúde pública. as tecnologias de disposição final têm sido objeto de discussão com comprometimento nesses dois campos. Como uma questão multifacetada. são registradas as mais diversas implicações para que seja apresentada uma solução a médio prazo. São comumente questionadas as imprecisões e divergências científicas sobre determinado método de disposição final, surgem disputas e interesses políticos e econòmicos. além do enfrentamento de questões sociais e culturais.

Por não ser de responsabilidade restrita. a problemática dos resíduos sólidos e seu destino adequado, no município de São Paulo, revela o desafio de fomentar o diálogo entre os mais diversos setores da sociedade. visando a uma tomada de decisão democrática e socialmente justa.

Devido à complexidade do tema. escolhemos para o estudo do aspecto comunicacional do gerenciamento ambiental o projeto do município para a instalação de duas plantas de incineração. que será apresentado adiante.

A apresentação deste estudo de caso. no entanto. será precedida pela apresentação da atual situação dos resíduos sólidos em São Paulo para melhor revelar a dimensão do problema. 


\section{2 - Classificação dos Resíduos Sólidos}

A Associação Brasileira de Normas Técnicas - ABNT classifica os resíduos sólidos de acordo com os riscos potenciais ao meio ambiente e à saúde pública. visando que seu manuseio assim como sua destinação final sejam adequados.

Residuos sólidos são aqueles em estado sólido. resultantes de atividades industrial, doméstica. hospitalar. comercial, de serviços. de varrição e agrícola. São considerados ainda nesta definição os lodos gerados em sistemas de tratamento de água ou em equipamentos $\mathrm{e}$ instalaçôes de controle de poluição. Integram também esta categoria determinados líquidos que. devido a suas particularidades e por demandarem soluçòes econòmica e tecnicamente inviáveis. mesmo com a melhor tecnologia disponivel no momento. não possam ser lançados na rede de esgotos (ABNT. 2000).

Segundo a $A B N T$. um residuo apresenta característica de periculosidade se. em função de suas propriedades lïsicas. químicas ou infecto-contagiosas apresentar riscos à saúde pública. gerando ou contribuindo. significativamente. para um aumento de monalidade ou incidència de doenças. assim como riscos ao meio ambiente. quando manuseado ou destinado inadequadamente.

Os resíduos sólidos são classificados. segundo a Norma NBR - 10.004 da ABNT, em três categorias: Classe I - perigosos. Classe II - não inertes e Classe III inertes e apresentam a seguinte classificação:

- Classe I - perigosos: são aqueles que apresentam riscos à saúde pública em função de suas características de inflamabilidade. corrosividade. reatividade. toxicidade e patogenicidade. 
- Classe II - não Inertes: são os residuos que não apresentam periculosidade. porém não são inertes, podem ter propriedades tais como: combustibilidade, biodegradabilidade ou solubilidade em água.

- Classe III - inertes: são aqueles que. ao serem submetidos aos testes de solubilização (NBR - 10.007) não tiverem nenhum de seus constituintes solubilizados em concentrações superiores aos padrões de potabilidade da água. Isto significa que a água permanecerá potável quando em contato com o residuo.

Deve-se ressaltar que integra neste estudo de caso apenas a problemática dos resíduos sólidos domiciliares. Classe II. definidos como aqueles provenientes de residências e também de indústrias. comércios e serviços. desde que suas produções sejam inferiores a 100 litros por dia. Essa classificação abrange ainda os provenientes de serviços de limpeza. tais como varrição. limpeza de feiras livres, favelas, córregos e bueiros (Prodam. 2000).

\section{3 - Geração de Resíduos Sólidos Domiciliares em São Paulo}

A cidade de São Paulo gera. diariamente. cerca de 7 mil toneladas de resíduos sólidos domiciliares e 5 mil toneladas de entulho. Esses rejeitos são todos os dias coletados. tratados e destinados a locais próprios. que. segundo estudos do Departamento de Limpeza Urbana - Limpurb estão com sua capacidade em processo de saturação (Prodam. 2000).

São mais de mil veículos de coleta que realizam diversas viagens por dia. transportando resíduos para diferentes pontos da cidade. Esses serviços de limpeza são contratados pelo Departamento de Limpeza Urbana - LIMPURB, da Secretaria de Serviços e Obras - SSO. A fiscalização é de responsabilidade da Secretaria das 
Administrações Regionais - SAR, por meio das Supervisões de Serviços das Administrações Regionais - AR's (Prodam. 2000).

A coleta e varrição envolvem sete contratos e atendem a um total de 27 Administraçòes Regionais - AR's. A administração municipal. portanto. é responsável pela coleta. transporte e destinação final de:

- Resíduos domiciliares:

- Resíduos gerados nos estabelecimentos comerciais até 100 litros por dia:

- Residuos gerados nos serviços de saúde públicos e privados:

- Entulhos. até 50 quilos. por domicílio. por dia:

- Qualquer residuo depositado clandestinamente nas vias e terrenos publicos.

Os grandes geradores. ou seja. aqueles que excederem a uma produção de 100 litros diários. são responsáveis pela remoção e destinação de seus resíduos.

Segundo dados da Limpurb. os serviços de coleta e varrição estão entre os mais caros da limpeza urbana. consumindo cerca de $75 \%$ dos recursos disponiveis para essa área. As usinas de compostagem. estações de transbordo. incineradores hospitalares e aterros respondem pelos $25 \%$ restantes. Em 1997 a cidade gastou com o funcionamento do sistema de limpeza urbana mais de LS\$ 1 milhào de dólares por dia. destes. US\$ 800 mil dólares para a coleta do lixo domiciliar e varrição da cidade (Prodam. 2000).

A arrecadação dessa verba é feita pela administração municipal por meio da cobrança de taxa de limpeza que integra as despesas taxadas no Imposto Predial e Territorial Urbano - IPTU cobrado dos cidadãos e empresas.

Segundo Gonçalves (1997). São Paulo e outras metrópoles brasileiras enfrentam o desafio de encontrar soluções racionais para a disposição e tratamento adequados de seus residuos. visando à minimização da degradação ambiental. A 
autora enfatiza a situação de São Paulo que. com quase todos seus locais de disposição final com capacidade esgotada e tecnologia obsoleta, necessita de investimentos em novas tecnologias de tratamento de lixo e de programas de redução e reutilização dos rejeitos diariamente coletados (Gonçalves. 1997).

Para Teixeira et al. (1997). se for comparada a outras cidades. São Paulo apresenta várias experiências de tratamento e destinação final de lixo. porém. o quadro ainda é preocupante. O controle ambiental é insuficiente. com impactos principalmente no entorno, tais como mau cheiro, proliferação de insetos etc.. $O$ montante de lixo gerado na cidade tem comprometido o bom funcionamento dos equipamentos. que quase sempre operam acima da capacidade (Teixeira et al.. 1997).

Para dispor adequadamente o resíduo sólido domiciliar. composto por mais de $60 \%$ de matéria orgânica e de $30 \%$ de inertes. a cidade conta com três aterros sanitários em operação. um deles para resíduos inertes. duas usinas de compostagem e um posto de recebimento da coleta seletiva (Prodam. 2000).

\section{4 - Aterros Sanitários}

Na cidade de São Paulo. os aterros sanitários correspondem à técnica mais recente de destinação linal de resíduos sólidos. implantados na década de 70.

Os problemas que os aterros próximos a áreas urbanas causam são visíveis e conhecidos da população. especialmente do entorno. Dá-se destaque aos odores, à geração de chorume - liquido de cor escura resultante da decomposição da matéria orgânica presente no lixo e à possível contaminação dos lençóis freáticos. Para evitá-los. é necessária a utilização de técnicas modernas de implantação e operação.

Segundo Gonçalves (1997). mais de $3 / 4$ do lixo em todo o mundo são conduzidos a aterros sanitários que. do ponto de vista econômico. são considerados 
pelas autoridades como menos dispendiosos e pelos ambientalistas como menos impactantes ao meio ambiente. sobretudo se forem comparados à tecnlogia da incineração, geradora de constantes polêmicas (Gonçalves. 1997).

Os aterros sanitários em operação na cidade são Bandeirantes. São João e Itatinga, este último para resíduos inertes. Existem ainda quatro aterros em fase de manutenção e recuperação da área. Santo Amaro, Sapopemba. São Matheus e Jacuí.

As tabelas a seguir apresentam as condições desses aterros sanitários.

Tabela 1 - Aterros sanitários em operação

\begin{tabular}{|c|c|c|c|}
\hline Aterro & Localização & Capacidade & Vida Útil \\
\hline Bandeirantes & $\begin{array}{l}\text { Rodovia dos } \\
\text { Bandeirantes } \\
\text { Bairro Perus } \\
\text { Zona Oeste }\end{array}$ & $\begin{array}{l}\text { Recebe cerca de } \\
165 \text { mil toneladas } \\
\text { de residuos por mès }\end{array}$ & $\begin{array}{l}\text { Em operação desde } \\
1995 \text { e previsto para } \\
\text { operar até } 2001 \text {, } \\
\text { receberá até o final de } \\
\text { suas atividades cerca de } \\
27 \text { milhòes de toneladas } \\
\text { de residuos }\end{array}$ \\
\hline Sítio São João & $\begin{array}{l}\text { Km } 33 \text { da Estrada } \\
\text { Sapopemba } \\
\text { Bairro São Matheus } \\
\text { Cona I ceste }\end{array}$ & $\begin{array}{l}\text { Recebe cerca de } \\
165 \text { mil toneladas } \\
\text { de residuos por més }\end{array}$ & $\begin{array}{l}\text { Em operação desde } \\
1992 \text { e previsto para } \\
\text { operar até } 2002 \text {. } \\
\text { receberá até o final de } \\
\text { suas atividades cerca de } \\
16 \text { milhões de toneladas } \\
\text { de residuos }\end{array}$ \\
\hline Itatinga & $\begin{array}{l}\text { Estrada do Retiro } \\
\text { Bairro Santo Amaro } \\
\text { Zona Sul }\end{array}$ & $\begin{array}{l}\text { Recebe cerca de } \\
100 \text { mil toneladas de } \\
\text { resíduos por més }\end{array}$ & $\begin{array}{l}\text { Em operação desde } \\
1990 \text { e previsto para } \\
\text { operar até } 98 \text {, receberá } \\
\text { até o firal de suas } \\
\text { atividades cerca de } 5 \\
\text { milhões de toneladas de } \\
\text { residuos }\end{array}$ \\
\hline
\end{tabular}

Fonte: Prodam, 2000 
Tabela 2 - Aterros sanitários em manutenção

\begin{tabular}{|c|c|c|c|}
\hline Aterro & Localização & Capacidade & Vida útil \\
\hline Jacuí & $\begin{array}{l}\text { Rua Arareua } \\
\text { Cidade Pedro } \\
\text { José Nunes } \\
\text { Zona oeste }\end{array}$ & $\begin{array}{c}\text { Recebeu cerca de } 2.5 \\
\text { milhões de toneladas de } \\
\text { lixo }\end{array}$ & $\begin{array}{l}\text { Este aterro operou de } \\
1980 \text { a } 1988 \text {, estando } \\
\text { atualmente } \\
\text { manutenção }\end{array}$ \\
\hline Santo Amaro & $\begin{array}{c}\text { Av. Naçòes Unidas com } \\
\text { Av. Interlagos } \\
\text { Zona Sul }\end{array}$ & $\begin{array}{l}\text { Recebeu cerca de } 16.2 \\
\text { milhões de toneladas de } \\
\text { lixo }\end{array}$ & $\begin{array}{l}\text { Este aterro operou de } \\
1976 \text { a } 1995, \text { estando } \\
\text { atualmente } \\
\text { manutenção }\end{array}$ \\
\hline Sapopemba & $\begin{array}{c}\text { Av. Sapopemba } s / n \\
\text { Jardim Rodolfo Pirani } \\
\text { Zona Leste }\end{array}$ & $\begin{array}{l}\text { Recebeu cerca de } 2.7 \\
\text { milhões de toneladas de } \\
\text { lixo }\end{array}$ & $\begin{array}{l}\text { Este aterro operou de } \\
1979 \text { a } 1984, \text { reativado } \\
\text { em } 1986 \text { e encerrado no } \\
\text { mesmo ano, estando } \\
\text { atualmente } \\
\text { manutenção }\end{array}$ \\
\hline Vila Albertina & $\begin{array}{c}\text { Rua José Aguirre } \\
\text { De Camargo } \\
\text { Tremembé } \\
\text { Zona Norte }\end{array}$ & $\begin{array}{c}\text { Recebeu cerca de } 9.2 \\
\text { milhões de toneladas de } \\
\text { lixo }\end{array}$ & $\begin{array}{l}\text { Este aterro operou de } \\
1977 \text { a 1993, estando } \\
\text { atualmente } \\
\text { manutenção }\end{array}$ \\
\hline
\end{tabular}

Fonte: Prodam. 2000.

Tabela 3 - Aterro sanitário em tàse de recuperação ambiental

\begin{tabular}{|c|c|c|l|}
\hline Aterro & Localização & Capacidade & \multicolumn{1}{|c|}{ Vida útil } \\
\hline São Matheus & Marginal esquerda & Recebeu cerca de & Operou de 1984 a 1985, \\
& do córrego & 1 milhão de toneladas de & $\begin{array}{l}\text { atualmente está em fase de } \\
\text { Fazenda Velha }\end{array}$ \\
& Zona Leste & residuos & \\
\hline
\end{tabular}

Fonte: Prodam, 2000. 


\section{5 - Usinas de Compostagem}

A compostagem é o processo que decompõe biologicamente a matéria orgànica - resto de comida. cascas de frutas e legumes. borra de café. casca de ovo. presente em $60 \%$ do lixo domiciliar. transformando-a em composto orgânico. utilizado como condicionador do solo. Esse composto fornece ao solo micro nutrientes tais como ferro, cobre e zinco. além de melhorar a sua estrutura.

Ao dar entrada na usina. o residuo domiciliar passa por um processo manual de seleção. visando à separação de vidro. plástico. papelão entre outras matérias não orgânicas. (ieralmente são os elementos maiores. facilmente percebidos. Em seguida passa por uma correia eletrostatica. onde são separados os materiais ferrosos, não detectados na primeira fase.

A parte organica segue para os biodigestores, onde ocorre o processo de decomposição aeróbia. alcançando uma temperatura de $70^{\circ} \mathrm{C}$. o suticiente para exterminar os micróbios patogenicos. germes e parasitas.

Essa matéria fica cerca de um dia nos biodigestores. Apos esse prazo é peneirada. o que ficou retido pelas peneiras, geralmente trapos de pano. sacos plásticos que estavam envolvidos com o lixo orgânico. são levados para os aterros sanitários.

A parte que passou pela peneira jả é o composto e deve ficar de 60 a 90 dias em um processo de cura. no qual por aquecimento e fermentação vai se transformando em húmus - produto da decomposiçào natural dos restos vegetais.

Há na cidade de São Paulo duas usinas de compostagem. a de Vila Leopoldina e de São Matheus. que recebem juntas cerca de $10 \%$ de todo o lixo 
coletado. normalmente os resíduos domiciliares das regionais mais próximas de onde estão instaladas.

O processo é considerado ecologicamente correto, mas há. nessas duas usinas. alguns problemas. Além do odor. o composto não é de boa qualidade, pois é possivel encontrar, principalmente, cacos de vidro. o que pode ser resultado do processo pouco eficiente da seleção manual ou da esteira eletrostática.

Outro agravante é a contaminação da matéria orgânica. O lixo ainda em sua fonte geradora, ou seja. nas residências. é misturado, como vimos. com materiais não orgànicos. Se junto à sobra de cozinha for disposto uma pilha ou resto de tinta. por exemplo. na qual estão presentes elementos como chumbo. cromo. mercúrio. cadmio. esta matéria orgânica estará contaminada por esses metais pesados. resultando em um composto igualmente comprometido.

O comprometimento da qualidade do composto é um dos fatores que dificultam sua melhor aceitação no mercado.

Por outro lado. o processo de compostagem exige a "cura" do composto por prazos que giram em torno de 60 dias. o que normalmente se constitui numa fonte de incòmodo às vizinhanças, além de exigir grandes áreas para instalaçào.

Tabela 4 - Usinas de compostagem em operação

\begin{tabular}{|l|l|l|l|}
\hline \multicolumn{1}{|c|}{ Usina } & \multicolumn{1}{|c|}{ Localização } & \multicolumn{1}{|c|}{ Capacidade } & \multicolumn{1}{|c|}{ Vida útil } \\
\hline Vila Leopoldina & Vila Leopoldina & $\begin{array}{l}\text { Recebe cerca de 3000 } \\
\text { toneladas de residuos } \\
\text { por mês }\end{array}$ & $\begin{array}{l}\text { Em operação desde } \\
1979\end{array}$ \\
\hline São Matheus & Bairro de São Matheus & $\begin{array}{l}\text { Recebe cerca de 15000 } \\
\text { toneladas de residuos } \\
\text { por mês }\end{array}$ & $\begin{array}{l}\text { Em operação desde } \\
1979\end{array}$ \\
\hline
\end{tabular}

Fonte: Prodam. 2000. 


\section{6 - Coleta Seletiva}

Coleta Seletiva é o processo no qual é feita a separação do lixo seco. composto por materiais como plástico, vidro, papel/papelão. metal e por matéria orgânica. resto de comida. O objetivo desse tipo de coleta é a reciclagem do material presente no resíduo doméstico, possibilitando sua transformação. artesanal ou industrialmente. em matéria prima.

O material reciclável, presente no lixo de São Paulo, é proveniente basicamente de embalagens tais como latas de óleo e de produtos alimentícios. vidros de maionese. frascos plásticos de vinagre. detergente. água mineral. revistas. jornais entre tantos outros elementos que, para grande parcela da população. ainda são conhecidos e dispostos como lixo.

Bem aceita ecologicamente. a reciclagem reduz a exploração de matéria prima virgem. diminuindo com isto o problema da escassez dos recursos naturais não renováveis. e contribui para a redução do consumo de energia. uma vez que o reprocessamento demanda menos energia se comparado ao que exige a matéria bruta.

A coleta seletiva feita porta a porta teve início em 1989. atendendo 3500 mil domicílios em apenas um circuito. formado por um conjunto de ruas do bairro de Vila Madalena. então escolhido como piloto. Atualmente essa coleta atende 37 circuitos, distribuidos em diversos bairros e atinge 102 mil domicílios ou uma população de aproximadamente 500 mil habitantes (Prodam. 2000).

O material coletado seletivamente é destinado ao centro de triagem de Vila Leopoldina. em atividade desde 1989, ano em teve início a coleta porta a porta e incrementado em abril de 1991. quando foi iniciada a coleta nos Postos de Entrega Voluntária - PEVs. Esse único centro de triagem em operação no momento tem capacidade nominal diária de 250 toneladas e de capacidade efetiva 198 toneladas. 
Administrada pela Prefeitura. tem produzido $95 \%$ de recicláveis e apenas $5 \%$ de rejeitos.

Os PEVs são outra forma de realizar a coleta seletiva. Compostos por um conjunto de quatro contêineres de cores diferentes - verde para coletar vidro. amarelo para metal, azul para papel e vermelho para plástico. Esse sistema depende de maior voluntariedade por parte da população que tem de separar os materiais em casa e depois deslocar-se até um posto de coleta mais próximo para depositá-los.

Instalados em locais públicos como parques, campus universitário, praças e conjuntos habitacionais. os PEVs somam 25 conjuntos espalhados pela cidade, especialmente em bairros que não se beneficiam com a coleta feita porta a porta.

Das 7 mil toneladas de residuos coletados diariamente em São Paulo. aproximadamente 10 toneladas sào provenientes da coleta seletiva domiciliar. Destes. $75 \%$ são do sistema porta a porta. $15 \%$ dos PEVs e $10 \%$ de doações.

O lixo coletado separadamente tem peso específico médio em torno de 0,08 toneladas $/ \mathrm{m} 3$. o que significa ser mais leve, porém volumoso em relação ao lixo comum. A tabela abaixo mostra a composição média desse residuo.

Tabela 5 -Composição média em peso do resíduo proveniente da coleta seletiva

\begin{tabular}{|l|c|}
\hline \multicolumn{1}{|c|}{ Material } & Parcela em \% \\
\hline Papel/papelão & 50 \\
\hline Plástico duro & 5 \\
\hline Plástico firme & 2 \\
\hline Vidro & 13 \\
\hline Metais ferrosos & 9 \\
\hline Metais não ferrosos & 1 \\
\hline Rejeitos & 20 \\
\hline
\end{tabular}

Fonte: Prodam, 2000. 
A coleta seletiva representa uma modesta participação no processo de gerenciamento de resíduos sólidos no município de São Paulo. São vários os argumentos que tentam justificar sua inviabilidade, fundamentados na apatia da população e no alto custo de sua operação. No entanto. esses argumentos têm sido gradativamente questionados.

Para Calderoni (1997), a idéia de que a coleta seletiva do lixo não é economicamente viável faz parte do discurso proterido tanto na literatura especializada quanto em debates públicos e particularmente em manifestações divulgadas pela midia. Segundo o autor. o contra-argumento não obtém o mesmo espaço.

Em um estudo sobre a viabilidade econômica da coleta seletiva para o Brasil e São Paulo. Calderoni reforça a importância de se observar a reciclagem no contexto da coleta seletiva. Sendo a coleta condição para a reciclagem. deve-se considerar a economia resultante de todo esse processo. Em especial os custos associados à economia de matéria prima. de energia e de controle ambiental economizados com a reciclagem.

A reciclagem. no contexto do desenvolvimento sustentável. é considerada como fator de economia do capital natural. tal como das matérias-primas. energia. água e de saneamento ambiental. pois reduz a poluição do ar. da água. do solo e do subsolo. Apesar de tal constatação. não existe uma politica de resíduos sólidos e tampouco de reciclagem. em nenhuma das esferas. seja federal. estadual ou municipal. Ao considerar o exemplo do municipio de São Paulo. verifica-se que os volumes envolvidos são tão reduzidos que podem ser considerados como de caráter meramente simbólico (Calderoni. 1997).

A tabela a seguir é um demonstrativo da economia de energia quando processada a matéria virgem em comparação com o material reciclável. 
Tabela 6 - Consumo de energia para processamento de matéria-prima virgem e de matéria reciclada

\begin{tabular}{|l|c|c|c|}
\hline Material & $\begin{array}{l}\text { MWh/t a partir de matéria-prima } \\
\text { virgem }\end{array}$ & $\begin{array}{l}\text { MWh/t a partir de materiais } \\
\text { recicláveis }\end{array}$ & $\%$ \\
\hline Alumínio & 17,6 & 0.7 & 95,0 \\
\hline Plástico & 6.74 & 1.44 & 78,7 \\
\hline Papel & 4,98 & 1.47 & 71,0 \\
\hline Aço & 6.84 & 1,78 & 74,0 \\
\hline Vidro & 4,83 & 4.19 & 13,0 \\
\hline
\end{tabular}

Fonte: IPT/CEMPRE, 1995.

Segundo Calderoni. existe uma metodologia para calcular a economia proveniente da coleta seletiva, no contexto da reciclagem. que necessita ser revisada. Desta forma, o autor sugere uma equação, presente na Tabela 7, que amplie os fatores envolvidos com a real viabilidade econômica dessa forma de destino final do lixo domiciliar.

Tabela 7 - Metodologias para calcular o ganho com a reciclagem. no contexto da coleta seletiva.

\begin{tabular}{|l|l|}
\hline \multicolumn{2}{|c|}{ Orientação metodológica } \\
\hline Atual & Proposta \\
\hline $\mathrm{G}=\mathrm{V}-\mathrm{C}+\mathrm{E}$ & $\mathrm{G}=\mathrm{V}-\mathrm{C}+\mathrm{E}+\mathrm{W}+\mathrm{M}+\mathrm{H}+\mathrm{A}+\mathrm{D}$ \\
\hline Onde: & $\mathrm{G}=$ ganho com a reciclagem \\
\hline $\mathrm{V}=$ venda dos materiais recicláveis \\
\hline $\mathrm{C}=$ custo do processo de reciclagem \\
\hline $\mathrm{E}=$ custo evitado de disposição final \\
\hline $\mathrm{W}=$ ganhos decorrentes da economia no consumo de energia (Wh) \\
\hline $\mathrm{M}=$ ganhos decorrentes da economia de matérias-primas \\
\hline $\mathrm{H}=$ ganhos decorrentes da economia de recursos hídricos \\
\hline $\mathrm{A}=$ ganhos com a economia de controle ambiental \\
\hline $\mathrm{D}=$ demais ganhos econômicos (divisas, subsídios, vida útil dos equipamentos etc.) \\
\hline
\end{tabular}

Fonte: Sabetai, 1997. p. 89. 
$\mathrm{O}$ autor cita uma pesquisa realizada pela Ciclosoft que revelou muito elevado o custo da coleta seletiva praticada em São Paulo, algo em torno de US\$ 294/t. acima do custo vigente em Curitiba. US\$179/t. e acima do encontrado para as oito capitais pesquisadas pelo Cempre. US\$240/t. Todos esses valores estão bem acima dos custos de uma coleta convencional de resíduo domiciliar. cerca de US\$ 30/t em São Paulo.

Alguns fatores podem justificar esses custos elevados, são eles: a) a baixa escala; b) espaço para armazenar; c) negociação: d) ausência de terceirização: e) otimização dos circuitos; f) separação e beneficiamento; g) planejamento e gestão (Cempre. 1995).

A inviabilidade econômica. segundo a Limpurb. que aponta um custo de operação de R\$ 400.00 a tonelada. também é considerada como um dos fatores que impedem sua aplicação em grande escala.

Ressalta-se que as informações aqui apresentadas têm como objetivo principal evidenciar a complexidade que envolve a problemática dos resíduos sólidos e não propor uma solução técnica para o problema.

Essas informações ajudam ainda a evidenciar as diversas facetas que envolvem a questão dos residuos sólidos domiciliares. revelando a necessidade de uma tomada de decisão que envolva os diversos atores sociais. no entanto. sem privilegiar a participação de um grupo em detrimento a de outros. 


\section{5 - ESTUDO DE CASO - PROJETO DE INSTALAÇÃO DE USINAS DE INCINERAÇÃO}

A prefeitura de São Paulo, diante da saturação dos aterros sanitários em operação e frente às dificuldades em encontrar áreas para possível instalação de novos aterros, tomou a decisão de instalar duas unidades de processamento (triagem e incineração) para o lixo urbano coletado no Município. As futuras unidades seriam instaladas, uma no terreno próximo ao antigo Aterro Sanitário de Santo Amaro e a outra em terreno contínuo ao Aterro de Sapopemba, em São Matheus (Prodam, 2000).

Foram abertas em fevereiro de 1994 licitações para empresas interessadas na construção das usinas de incineração de resíduo domiciliar. Venceram a concorrência pública dois consórcios, Etesco/Bartolomei para o incinerador de Santo Amaro e Vega/CGC/Martin, para a instalação em Sapopemba. Cada usina, orçada em cerca de US\$ 150 milhões. teria capacidade para incinerar 2500 toneladas de resíduos domiciliares por dia.

O empreendimento. que abrange a construção e o funcionamento, de responsabilidades das empresas concessionárias. teria a concessão por um periodo de 20 anos. Após esse período. os dois incineradores passariam para a municipalidade.

A proposta de construção dessas duas usinas causou imediatamente repúdio da população, em especial, dos moradores dos bairros escolhidos para receber tais plantas. Foram organizados abaixo-assinado contra a instalação e várias manifestações em pontos estratégicos da cidade.

Os moradores criaram movimentos organizados, buscando apoio e informação nas organizações não-governamentais como Greenpeace, SOS Mata Atlântica, e principalmente com alguns parlamentares. 
Foram realizadas ainda no final de 1994 duas audiências públicas para apresentar os resultados do Estudo de Impacto Ambiental e seu Relatório de Impacto Ambiental. EIA-RIMA. executados, individualmente, para as usinas de incineração.

Presentes nessas audiências. os moradores de São Matheus e de Santo Amaro demonstraram. por meio de breves intervenções. suas posições. As discussões. apesar de tenderem mais para o enfoque técnico. já que tratava-se da análise de um estudo de impacto ambiental, registraram também indignação popular diante de uma proposta que consideraram antidemocrática e tecnicista.

A polêmica. envolvendo essa proposta da Prefeitura de São Paulo. ganhou espaço nos meios de comunicação que passaram a registrar cada novo episódio. As reportagens abordaram as divergências técnicas quanto à emissão de substâncias como dioxinas e furanos. os pareceres dos órgãos competentes. as manifestações populares etc.

O EIA/RIMA foi submetido ao Conselho Municipal de Meio Ambiente e Desenvolvimento Sustentável - CADES. orgão ambiental do municipio de São Paulo. instituído nos termos dos artigos 22 da Lei 11.426 de 18 de outubro de 1993 e regulamentado pelo Decreto 33.804 de 17 de novembro de 1993.

Integram as atribuições do CADES a apreciação e o pronunciamento sobre EIA/RIMA. no âmbito do municipio de São Paulo. Quanto à aprovação ou rejeição desses Estudos. a responsabilidade é do Secretário Municipal do Verde e do Meio Ambiente (Prodam. 2000).

O EIA/RIMA da usina de incineração de Sapopemba foi aprovado conforme disposto na Resolução CADES 08/95. mediante o acréscimo de algumas exigências e recomendações. 
Esse processo de apreciação e aprovação do EIA/RIMA pelo CADES revelou-se totalmente atípico. sobretudo pela exclusão da participação dos órgãos estaduais responsáveis pela emissão de licença ambiental.

Apesar de aprovado pelo CADES, o projeto de instalação das duas usinas de incineração foi posteriormente arquivado tanto por falta de verbas para início da construção quanto por implicações legais com as autoridades estaduais de meio ambiente.

As discussões acerca dos impactos ambientais e para a saúde pública, provocados pelos incineradores. reúnem uma série de elementos para o entendimento da dinâmica da comunicação de riscos. Deve-se ressaltar. porém. que a avaliação e o gerenciamento dos riscos associados. boa parte, às emissões atmosféricas de gases tóxicos, por sua amplitude técnica. não serão objeto de estudo desta pesquisa.

\section{1 - Tecnologia de incineração}

Tecnologia térmica para tratamento de residuos. a incineração corresponde à queima de materiais em alta temperatura (geralmente acima de 800 ${ }^{\circ} \mathrm{C}$ ), em mistura com uma quantidade apropriada de ar e durante um tempo determindado (Oppelt. 1987).

Essa combustão acontece em uma instalação que recebe o nome de usina de incineração. Antes do processo da queima faz-se necessária a caracterização correta dos resíduos a fim de evitar danos ao meio ambiente e à saúde pública.

A tecnologia da incineração é complexa e ainda provoca polêmica entre os diversos segmentos da sociedade. Com o objetivo de esclarecer a opinião pública 
sobre os riscos provocados pela incineração, a Limpurb elencou alguns aspectos positivos e negativos da incineração de residuos sólidos domiciliares (Prodam, 2000).

Vantagens da incineração do lixo (Prodam. 2000):

- Destoxificação. A incineração elimina bactérias. vírus e compostos orgânicos. como o tetracloreto de carbono e óleo ascarel e. até. dioxinas. $\mathrm{Na}$ incineração. a dificuldade de destruição não depende da periculosidade do resíduo. e sim de sua estabilidade ao calor. A incineração também pode ser usada para descontaminar solo contendo resíduos tóxicos que. depois de incinerado. é devolvido ao seu lugar de origem:

- Redução do impacto ambiental. Em comparação com o aterro sanitário. a incineração minimiza a preocupação a longo prazo com monitorização do lençol freático já que o resíduo tóxico é destruído e não guardado:

- Redução drástica do volume a ser descartado. A incineração deixa como sobra apenas as cinzas que geralmente são inertes, reduzindo. desta forma. a necessidade de espaço para aterro:

- Recuperação de energia. Parte da energia consumida pode ser recuperada para geração de vapor ou eletricidade.

Desvantagens da incineração do lixo (Prodam. 2000):

- Custo elevado. A incineração é um dos tratamentos de resíduos que apresenta custos elevados tanto no investimento inicial, quanto no custo operacional. Normalmente. deve-se incinerar apenas o que não pode ser reciclado. Hoje. com as crescentes exigências para mitigação 
dos impactos ambientais causados pelos aterros sanitários. estes estão chegando a custar mais de US\$20 por tonelada. atingindo a faixa de custo operacional dos incineradores US\$17/t.

- Problemas operacionais. A variação da composição dos residuos pode resultar em problemas de manuseio de resíduo e operação do incinerador e. também, exigir manutenção mais intensa:

- Limite de emissões de componentes da classe das dioxinas e furanos. Não existe consenso quanto ao limite de emissão dessas substâncias pelos incineradores:

- Exige mão-de-obra qualificada. É difícil encontrar e manter pessoal bem qualificado para supervisão e operação dos incineradores.

Algumas considerações. no contexto da discussão proposta nesta pesquisa. merecem atençào.

Apresentada como positiva. a idéia de que os incineradores podem ser utilizados como fonte de energia. sobretudo. em um momento em que a economia de energia elétrica torna-se ponto crucial. especificamente no Brasil. o argumento parece encaminhar para uma discussão sobre a compensaçào. ou seja. o custo-beneficio. Significa que. se comprovado os riscos dos incineradores para o meio ambiente e para a saúde. esses podem ser compensados com a geração e a redução do custo de energia para a população.

Essa informação. se disseminada em um momento de racionamento de energia. pode revelar um aspecto perverso - muitas vezes implicito no processo de tomada de decisão.

No que diz respeito à comunicação, esse tipo de informação pode ser utilizado para auxiliar na busca de um consenso. revelando com isso um perfil manipulativo. 
Constata-se ainda que nos aspectos negativos não foi considerada a polèmica que envolve a tecnologia em questão. sobretudo. referente às divergências técnicas, às imprecisões científicas acerca dos poluentes emitidos, aos conflitos gerados entre os diversos atores envolvidos.

Um aspecto comunicacional interessante sobre a incineração é o uso pelos empreendedores, ou proponentes. de dados. números, histórias. nem sempre apurados, revelando a quantidade de incineradores no mundo. suas localizações. transmitindo com isso a idéia de tratar-se de algo seguro pelo simples fato de existir nos paises desenvolvidos.

Esse mesmo artifício, no entanto, é utilizado pelos opositores. É comum representantes de entidades ambientalistas terem na cabeça o número exato de incineradores que foram fechados. especialmente nos países desenvolvidos.

\section{2 - Dioxinas e Furanos}

As questões relacionadas às dioxinas e aos furanos correspondem. nesta pesquisa. ao que foi apresentado como rumor, ou seja. uma informação que merece ser checada antes de disseminada. principalmente, pelos meios de comunicação.

Tanto na Audiência Pública quanto no material jornalístico, as informações sobre dioxinas e furanos prevaleceram no debate entre os grupos favoráveis e desfavoráveis ao projeto.

As dioxinas e furanos constituem uma classe de substâncias organocloradas em que alguns compostos são extremamente tóxicos. Essas substâncias sintéticas podem estar presentes nos resíduos ou serem formadas durante 
o processo de resfriamento dos gases ou ainda em decorrència de alguma irregularidade operacional (Prodam. 2000).

Existe um consenso técnico que aponta para a possível formação de dioxinas no processo de resfriamento dos gases de exaustão do incinerador. Para evitar sua formação. que ocorre após a incineração. sugere-se que ocorra um resfriamento brusco dos gases. não permitindo com isso a recuperação de energia (Oppelt. 1987).

Alguns países que possuem usinas de incineração definiram os limites para emissão dessas substâncias. No Brasil foi adotado o limite de $0.14 \mathrm{ng} / \mathrm{NM} 3$, conforme estabelecido na NB 1265 - Incineração de Resíduos Sólidos/Padrões de Desempenho (Oppelt. 1987).

Estudos sobre os riscos dessas substâncias. especificamente no Brasil. ainda são escassos. Durante as discussōes acerca do projeto da Prefeitura. foi utilizado como referência um estudo então desenvolvido pela U.S.EPA e publicado em setembro de 1994. no qual a agência ambiental dos Estados Unidos apresenta uma revisão dos riscos ambientais e de saúde pública derivados da exposição às dioxinas (Allsopp. 1994).

Esse documento complexo. contendo mais de 2500 páginas. foi totalmente simplificado e utilizado de acordo com os interesses dos grupos envolvidos.

São inúmeros os danos provocados pela simplificação ou interpretação de estudos científicos. especificamente neste caso. Para a implantação de um programa de comunicação de riscos que visa à democratização do processo de tomada de decisão, essa estratégia de manipulação da informação. independente do grupo social. também provoca consequências negativas. 
Para Jacobi (1997), um dos aspectos mais complexos da atualidade é o estabelecimento de medidas que viabilizem a participação da sociedade no debate sobre soluções racionais para o tratamento adequado dos resíduos sólidos.

Segundo o autor. é nitido o conflito entre os preceitos da sustentabilidade ambiental e a identificação de uma sociedade de riscos. "Isto implica na necessidade da multiplicação de práticas sociais pautadas pela ampliação do direito à informação e de educação ambiental numa perspectiva integradora"(Jacobi, 1997. p. 11).

A solução para o problema da democratização do processo de tomada de decisão, na área ambiental, na visão de vários pesquisadores, parece depender do grau de informação da sociedade sobre as questões relacionadas ao meio ambiente. A questão. no entanto. revela maior complexidade. como será apresentado e discutido nos Capitulos 6 e 7 . 


\section{6 - AUDIÊNCIA PÚBLICA COMO FERRAMENTA DE COMUNICAÇÃO DE RISCOS}

\section{1 - Introdução}

No cenário do gerenciamento ambiental tem sido comum a indagação sobre a possibilidade de identificar a Audiência Pública como uma ferramenta de comunicação. mais especificamente. no contexto do gerenciamento de riscos ambientais.

Não há oficialmente nenhuma referência direta na legislação ambiental brasileira que identifique a Audiència Pública como um instrumento de comunicação. No entanto. referenda-se em discurso. sobretudo pelas autoridades competentes. essas reuniões como um momento propicio para estabelecer a comunicação entre os diversos atores sociais envolvidos com determinada problemática ambiental.

Entretanto. demanda-se uma melhor identificação da definição de comunicação utilizada ou idealizada por tais autoridades. Se compreendida como mera transmissão de informações de fontes especializadas para a de não especialistas. no cenário ambiental, a Audiência Pública tende a revelar determinada estrutura. Se. no entanto. sua compreensão exceder a esta definição e for vista como um processo social que visa à comunhão de idéias, ao estabelecimento do entendimento entre as partes. naturalmente outra estrutura será revelada.

Desta forma. no primeiro momento deste capítulo, pretende-se apresentar a estrutura e a dinâmica da Audiência Pública. conforme prevista pela legislação ambiental.

$\mathrm{Na}$ segunda parte realiza-se uma análise da Audiência Pública sobre o EIA/RIMA do incinerador de residuo sólido de Sapopemba, parte integrante do objeto de estudo. visando a identificar na prática da Audiência Pública uma possível aproximação com um processo de comunicação. 
Conforme já explicitado no Capítulo 2. optou-se pela análise de apenas uma das duas Audiências Públicas, sobre as usinas de incineração, por considerar redundante a análise. Desta forma, por opção. foi escolhido o processo referente ao incinerador de Sapopemba.

Destaca-se ainda como objetivo principal desta etapa da pesquisa, a partir de um resgate parcial das idéias expressas e discutidas no Capítulo 3, a identificação da Audiência Pública como um processo que viabilize não apenas o acesso à informação. mas principalmente a participação dos diversos atores sociais na tomada de decisão.

\section{2 - Licenciamento com Avaliação de Impacto Ambiental}

A Audiência Pública. referida na Resolução CONAMA 1/86, corresponde a uma das etapas previstas para a obtenção da Licença Ambiental. concedida pelo órgão de controle ambiental do Estado de São Paulo. quando o empreendimento revelar possível impacto ao meio ambiente (Ambiente. 2001)

Os procedimentos necessários para o licenciamento ambiental estão descritos na Resolução SMA $42 / 94$ (Ambiente. 2001). A idéia de apresentar esses procedimentos está fundamentada na necessidade de revelar sua complexidade. assim como de identificar o meio de divulgação utilizado pelas autoridades competentes e pelo empreendimento para informar a sociedade sobre o processo em andamento.

As informações aqui expressas foram então extraídas da Resolução SMA 42 de 1994, na qual está prevista a realização de pelo menos dezoito etapas. reproduzidas a seguir.

Deve-se ressaltar que o procedimento a seguir não corresponde, na íntegra. ao adotado no caso em questão, como já observada sua singularidade. No entanto, esta 
pesquisa considerou relevante a exposição das etapas comuns para o licenciamento ambiental. especialmente por permitir uma melhor observação do fenômeno comunicacional no cenário ambiental geral e não apenas no do caso estudado.

1. Requerimento, pelo interessado. da Licença Ambiental Prévia com Relatório Ambiental Preliminar-RAP:

Esse requerimento. incluindo a entrega do RAP. é feito na Secretaria do Meio Ambiente. Outros documentos são entregues mediante a solicitação. incluindo o Exame Técnico expedido pelo órgão ambiental do município. A Deliberação Consema 08/99 exige do interessado a publicação do pedido de licença no Diário Oficial - D.O.E. em jornal de grande circulaçào e em jornal local.

A sociedade tem 30 dias para manifestar sua posição. após a data da publicação. A manifestação da sociedade poderá. de acordo com a decisão da SMA/DAIA. resultar em uma Reunião Técnica Informativa. Resolução SMA 11/98. A participação é aberta a todos, sendo obrigatória a presença do empreendedor. de sua equipe técnica e dos servidores vinculados à SMA e envolvidos com o processo de licenciamento. A realização da reunião será anunciada por jornal de grande circulação. sendo os custos de responsabilidade do interessado.

Essa etapa finaliza-se com a abertura de outro prazo. 10 dias, para nova manifestação.

2. Análise do RAP pela SMA/DAIA:

A Secretaria de Meio Ambiente analisa o Relatório Preliminar incluindo possiveis complementações. tais como as manifestações da sociedade.

3. Publicação da exigência do EIA/RIMA: 
A Secretaria do Meio Ambiente, após indeferir o RAP. exige o Estudo de Impacto Ambiental-EIA e do seu respectivo Relatório de Impacto Ambiental-RIMA. Essa exigência é publicada no Diário Oficial do Estado. A partir da data de publicação. a SMA concede um prazo de 180 dias para a apresentação de Plano de Trabalho.

4. Prazo para solicitação de Audiência Pública:

O empreendedor tem de tornar público o estabelecimento do prazo de 45 dias para a solicitação de realização de Audiência Pública. Esse processo está previsto na Deliberação Consema 08/99.

5. Apresentação do Plano de Trabalho:

O Plano de Trabalho é apresentado pelo empreendedor visando à elaboração do EIA/RIMA.

6. Informação ao Consema sobre o recebimento do Plano de Trabalho:

A Secretaria do Meio Ambiente informa o recebimento do Plano de Trabalho ao Consema que, por sua vez pode solicitar a avocação desse documento conforme as implicações ambientais provocadas pelo empreendimento.

7. Definição do Termo de Referência:

A Secretaria do Meio Ambiente. com base no Plano de Trabalho. define o Termo de Referência o qual é publicado no Diário Oficial do Estado. caso seja indeferido. haverá a publicação de novo prazo. 


\section{Apresentação do EIA/RIMA:}

O empreendedor apresenta o EIA/RIMA acompanhado do Termo de Referência. Cópias do EIA são entregues ao DAIA. à biblioteca da SMA e ao Consema. A distribuição de cópias do RIMA é feita ao DAIA. às Câmaras Técnicas envolvidas. à biblioteca da SMA. ao Consema. Se solicitado, o RIMA pode ser encaminhado à Assembléia Legislativa e ao órgão ambiental do municipio.

9. Divulgação do recebimento do EIA/RIMA e solicitação de Audiência Pública:

Por meio de publicação no Diário Oficial do Estado e em jornal de grande circulação. a SMA anunciará o recebimento do EIA/RIMA e determina o prazo para solicitação de Audiência Pública. que não deverá ser inferior a 45 dias.

10. Análise do EIA pela SMA:

A Secretaria do Meio Ambiente analisa o EIA/RIMA e sua complementação. A SMA considera as manifestações enviadas por escrito ou aquelas apresentadas na Audiência Pública. Essa etapa dá origem à emissão de Parecer Técnico sobre a viabilidade ambiental do projeto.

11. Emissão de parecer técnico e de condições de licença:

$O$ órgão ambiental. SMA. emite o Parecer Técnico no qual determina as condições para Licença de Instalação e de Operação.

12. Publicação da Súmula:

O Consema publica um breve resumo no D.O.E. e encaminha cópias aos conselheiros que integram o Plenário do Consema para a análise do empreendimento. $\mathrm{O}$ prazo para essa divulgação é de até 8 dias antes da reunião plenária. 
13. Aprovação do empreendimento:

O Consema emite deliberação para aprovação do empreendimento e encaminha o processo para a SMA/DAIA.

14. Emissão da Licença Prévia:

A Licença Prévia é emitida pela SMA e publicada no Diário Oficial do Estado.

15. Requerimento de Licença de Instalação:

Nessa etapa. o empreendedor. caso tenha cumprido com as exigências. solicita ao órgão ambiental a Licença de Instalação.

16. Emissão de Licença de Instalação:

A Secretaria do Meio Ambiente emite Parecer Técnico com cópia ao Consema. Nessa fase é emitida a Licença de Instalação com prazo de validade determinado. Esse processo também é publicado no D.O.E..

17. Requerimento de Licença de Operação:

O empreendedor. após cumprir as demais etapas. solicita ao órgão ambiental competente a Licença de Operação. 
18. Emissão de Parecer Técnico:

A Secretaria de Meio Ambiente emite o Parecer Técnico com cópia ao Consema. emitindo assim a Licença de Operação com prazo determinado de validade. Como ocorre em outras etapas. essa também é publicada no Diário Oficial do Estado.

Ressalta-se que se o empreendimento em questão demandar por Licença da Cetesb, as etapas para emissão das licenças de instalação e de funcionamento são de responsabilidade da agència ambiental.

As licenças de instalação e de operação são comunicadas ao Consema apenas em casos de licenciamento com EIA/RIMA.

Verifica-se que boa parte do procedimento é divulgada à sociedade. No entanto, tem prevalecido sua divulgação por meio de publicação no Diário Oficial do Estado. Como expresso acima. em algumas etapas a divulgação também acontece em jornais de grande circulação, o que tende a garantir o acesso da sociedade como um todo. dos cidadãos e não apenas o de grupos organizados da sociedade civil - público mais atento às publicações do D.O.E..

A publicação dos procedimentos ambientais nos veículos citados é compreendida apenas como disseminação de dados. de informações. visando a torná-lo de conhecimento público, a quem interessar. Essa medida, no entanto, não pode ser confundida com um processo de comunicação.

Pretende-se no próximo tópico deste capítulo identificar a Audiência Pública como um possível instrumento de comunicação de riscos ambientais. Para isso, deve-se resgatar em quais condições e com qual estrutura esse processo ocorre. 


\section{3 - Audiência Pública na legislação ambiental}

A Resolução CONAMA 09/87 define como finalidade da Audiência Pública a exposição do conteúdo do EIA/RIMA do empreendimento em análise. visando à diminuição de dúvidas e ao recolhimento de críticas e sugestões emitidas pelos presentes no evento (Ambiente. 2001).

A Audiência Pública. conforme a Deliberação Consema 50/92 que normatiza sua convocação, é definida como uma reunião que tem como objetivo debater. conhecer e informar a opinião pública sobre a implantação de determinado empreendimento de considerável impacto ambiental (Ambiente. 2001).

A realização de Audiencias Públicas. de acordo com a Resolução Consema 50/92. prevè o debate do licenciamento ambiental de um empreendimento sempre que julgar necessário ou quando for fundamentalmente solicitada pelas seguintes representações sociais:

a) Poder Público ou Municipal do Estado de São Paulo:

b) Conselho Estadual de Meio Ambiente - Consema:

c) Ministério Público Federal ou do Estado de São Paulo:

d) Entidade civil constituída há mais de um ano:

e) Cinquenta ou mais cidadãos:

As Audiências de empreendimentos sujeitos a EIA/RIMA podem ocorrer em qualquer uma das fases nas quais ocorrem a análise e tramitação do EIA. Todos os documentos apresentados à mesa diretora, durante a Audiência. são anexados ao processo e podem servir de base para análise e parecer final do órgão licenciador.

As Audiências Públicas. que devem ocorrer em locais de fácil acesso aos interessados, são integradas por uma mesa diretora. uma tribuna e um plenário. A mesa 
diretora é composta por autoridades da área ambiental. tais como secretários de meio ambiente e do Consema.

A dinâmica de cada Audiência está diretamente relacionada à sua organização, composta por quatro etapas. A tabela a seguir apresenta essas principais etapas e seus respectivos atores envolvidos.

Tabela 8 - Estrutura e dinâmica de uma Audiência Pública.

\begin{tabular}{|c|c|c|}
\hline ETAPAS & PARTICIPANTES & TEMPO \\
\hline - Abertura & - Secretário do M.A ou representante & Não definido \\
\hline - Exposição & $\begin{array}{l}\text { - Empreendedor: } \\
\text { - Equipe técnica responsável pelo EIA; } \\
\text { - Representante das entidades ambientalistas. }\end{array}$ & $\begin{array}{l}\text { - } \quad 15^{\circ} \text { por pessoa } \\
\text { - } 30^{\circ} \text { por pessoa } \\
\text { - } \quad 30^{\circ} \text { por pessoa }\end{array}$ \\
\hline - Manifestação & $\begin{array}{l}\text { - Entidades da sociedade civil: } \\
\text { - Pessoas presentes* } \\
\text { - Membros do Consema: } \\
\text { - Parlamentares: } \\
\text { - Prefeitos e Secretários }\end{array}$ & $\begin{array}{l}\text { - } 5 \text { por pessoa; } \\
\text { - } 2 \text { por pessoa; } \\
\text { - } 5 \text { por pessoa; } \\
\text { - } 5 \text { por pessoa; } \\
\text { - } 5 \text { por pessoa. }\end{array}$ \\
\hline - Réplica & $\begin{array}{l}\text { - Empreendedor: } \\
\text { - Equipe técnica responsável pelo EIA; } \\
\text { - Representante das Entidades ambientalistas. }\end{array}$ & $\begin{array}{l}\text { - } 10^{\circ} \text { por pessoa } \\
\text { - } 10^{\circ} \text { por pessoa } \\
\text { - } 10^{\circ} \text { por pessoa }\end{array}$ \\
\hline - Encerramento & - Secretário do M.A. ou representante & - Não definido. \\
\hline
\end{tabular}

* o tempo total desse conjunto de manifestações não pode exceder 60 minutos.

Fonte - Deliberação Consema. n 50. 20/11/1992 (Ambiente. 2000). 


\section{4 - Análise da Audiência Pública - incinerador de Sapopemba}

A Audiência Pública sobre o Estudo de Impacto Ambiental-EIA e do respectivo Relatório de Impacto Ambiental-RIMA da Usina de Processamento de Residuos Sólidos Domiciliares com Incineração. Recuperação de Energia Elétrica. proposta para ser instalada no bairro de Sapopemba. zona leste da cidade de São Paulo. ocorreu no mês de novembro de 1994. Sua realização foi solicitada pelo então presidente da Câmara Municipal de São Paulo. vereador Miguel Colasuonno ( SÃO PAULO. 1994).

\subsection{1 - Da estrutura e dinâmica}

A mesa diretora dessa Audiência foi composta pelo presidente e pela coordenadora do Conselho Municipal de Meio Ambiente e Desenvolvimento Sustentável CADES, e por um representante da Assessoria Técnica da Secretaria Estadual do Meio Ambiente.

Na Audiencia Pública do incinerador de Sapopemba. conduzida e coordenada pelo Secretário Municipal do Meio Ambiente. a determinação de utilização do tempo difere daquela apresentada na Tabela 8. Essa alteração, prevista na Deliberação Consema 50/92. é possível quando tratar-se de Audiencia Pública para análise de planos, programas ou empreendimentos com EIA/RIMA e que possam provocar considerável degradação ambiental. Nessa especificação o caso da Audiència de Sapopemba pode ser incluído.

A alteração mencionada ocorreu em duas etapas. na exposição e réplica do empreendedor e na réplica da equipe técnica responsável pelo EIA/RIMA 
Com essas alterações do tempo de fala do emprendedor e da equipe técnica do EIA/RIMA não é possivel identificar prejuizo direto ou mensurar danos concretos a essa tentativa de democratização da tomada de decisão. no entanto. em uma arena de visíveis conflitos e interesses distintos, como serão apresentados adiante. tal mudança pode conotar uma tentativa de manipulação.

As mudanças feitas pelo presidente da mesa. conforme dados apresentados na Tabela 9 são significativos. Foi concedido ao empreendedor, para a exposição. o dobro do tempo. ou seja. 30 minutos. Na réplica a diferença foi de $50 \%$. A equipe técnica também foi beneficiada com $50 \%$ a mais no tempo da réplica.

Não pretende-se neste capitulo realizar uma pesquisa quantitativa. entretanto. essa quantificação tende a subsidiar a análise sobre o conflito gerado nessa Audiência Pública.

Ressalta-se que o tempo apresentado na tabela abaixo refere-se ao apresentado pelo presidente da mesa. não sendo. necessariamente. o tempo utilizado por cada representante das etapas do evento. Como esta análise fez uso da transcrição integral das participações na Audiència Pública. incluindo as manifestações da platéia tais como palmas e vaias. não foi possivel registrar o tempo utilizado por cada exposição ou manifestação. Registra-se. no entanto. que o presidente da mesa fez várias interferèncias. solicitando o cumprimento do tempo de fala determinado. 
Tabela 9 - Estrutura e dinâmica da Audiência Pública sobre o incinerador de Sapopemba.

\begin{tabular}{|c|c|c|}
\hline ETAPA & RESPONSÁVEL & TEMPO \\
\hline - Abertura & $\begin{array}{l}\text { - Secretario do Verde e do Meio Ambiente do } \\
\text { Municipio de São Paulo - Sr. Werner Zulaut. }\end{array}$ & - Indefinido \\
\hline - Exposiçâo & $\begin{array}{l}\text { - Empreendedor: } 3 \text { representantes do consorcio: } \\
\text { - Equipe técnica: } 6 \text { técnicos da equipe responsável } \\
\text { pelo EIA RIMA: } \\
\text { - Entidades da sociedade civil: } 8 \text { representantes de } \\
\text { entidades afins. }\end{array}$ & $\begin{array}{l}\text { - } 30 \text { total } \\
\text { - } 30 \text { total } \\
\text { - } \quad 30 \text { 'total }\end{array}$ \\
\hline - Manitestações & $\begin{array}{l}\text { - Presentes: } 20 \text { pessoas manifestaram-se: } \\
\text { - Parlamentares: } 3 \text { deputados e } 04 \text { vereadores: }\end{array}$ & $\begin{array}{l}\text { - 2'p. pessoa } \\
\text { - } 5 \text { p. pessoa }\end{array}$ \\
\hline - Réplica & $\begin{array}{l}\text { - Empreendedor: I representante: } \\
\text { - Equipe técnica: } 2 \text { téenicos da equipe do EIA. }\end{array}$ & $\begin{array}{l}\text { - } 15^{\circ} \text { total } \\
\text { - } 15^{\circ}\end{array}$ \\
\hline - Encerramento & - Secretario Werner /ulaut & - Indefinido \\
\hline
\end{tabular}

Fonte: transcriçào da Audiència Publica realizada em 26/11/1994 na Camara. Municipal de SP.

\subsection{2 - A Abordagem no Discurso dos Atores Sociais}

A idéia de apresentar. parcialmente. o discurso dos principais presentes na Audiência Pública fundamenta-se na importància de identificar as assuntos. idéias e preocupaçòes predominantes.

Esse registro deve conduzir para a análise. objeto principal deste estudo. da viabilidade de tornar a Audiência Pública um instrumento de comunicação de riscos que visa à democratização do processo de tomada de decisão. sobretudo. por considerar os anseios. inseguranças e posicionamentos dos diversos segmentos da sociedade.

A Audiència Pública não está prevista. explicitamente. na legislação brasileira como um instrumento de comunicação. no entanto. como jả mencionado anteriormente. essa função comumente tem sido a ela atribuida.

Verifica-se que a apresentação das pessoas e de seus respectivos discursos. a seguir. obedeceu à sequència da participaçào dos grupos ocorrida na Audiência de 
Sapopemba. Ressalta-se que seus nomes foram omitidos. sobretudo. pelo fato desta tese não ter como objetivo a discussão sobre o certo ou errado e nem a elaboração de julgamentos.

A idéia principal é reproduzir uma parte significativa das participações de maneira simplificada e crítica. Registra-se ainda que a exposição abaixo privilegiou a exposição dos presentes. especialmente para identificar uma relação entre a abordagem e 0 tempo determinado de 2 minutos.

Os detalhes sobre a exposição técnica não integra objeto de estudo desta pesquisa. portanto. foi cooptado da fala da equipe técnica sua posição diante do empreendimento. do problema des residuos sólidos e da Audiencia Pública. em detrimento à apresentaçào de dados e informaçòes mais detalhadas sobre a tecnologia da incineração.

Desta forma. estão abaixo especificados os principais registros da participação dos diversos atores sociais envolvidos na Audiência Pública de Sapopemba. realizada no mès de novembro de 1994.

\section{a) Primeira Parte - Abertura}

- Secretário Municipal do Meio Ambiente - Werner Zulauf

() Secretário iniciou a Audiência Pública ressaltando que aquele procedimento correspondia a um ato democrático, adotado em todo o mundo. Seu discurso. políticodemocrático. legitimador e civilizatório. acentuou que a participação de todos era responsavel pelo destino da populaçào e que existia poder igual de decisão. Énfase à idéia de democracia.

Ao comentar sobre o incinerador como recurso de destinação tinal de residuos. o fez de uma maneira neutra. ou seja. tentou eliminar pontos polêmicos e o jogo de 
interesse. Ressaltou tratar-se de assunto polêmico por natureza. neutralizando polêmicas e divergências causadas por interesses diversos.

Expressou seu objetivo de ver uma discussão produtiva (prática-objetiva) em regime de disciplina , enquadrando-a na triade ordem- progresso-visão positivista.

Reforçou ainda que seria rigoroso em relação a tumultos. assumindo um papel de guardião da ordem e da democracia. No final seu discurso tornou-se predominantemente político.

\section{b) Segunda Parte - Exposição}

\section{Empreendedor:}

\section{Primeiro Expositor:}

Dividido em etapas. cabia a cada representante acentuar determinado segmento do empreendimento. desde a arquitetura à tecnologia a ser utilizada.

O primeiro especialista a participar apresentou uma maquete da usina de incineração. para que fosse vista a arquitetura da construção. sobretudo, pelo seu impacto visual. estético. moderno e arrojado.

Prevaleceu em seu discurso a questão da modernidade e do modelo, pois o que é usado nos países desenvolvidos é bom e se é bom pode-se utilizar, pois há o aval de qualidade do pais desenvolvido.

O custo-beneficio também foi apresentado de maneira positiva. revelando que o custo financeiro da obra seria totalmente subsidiado e com retorno direto e indiretamente 
para a população. Há a idéia de mascarar assim os reais interesses do empreendedor, que é o lucro de investimento e não o benefício da população.

Para ressaltar a segurança do empreendimento relata que usinas de incineração existem em grandes centros urbanos de países civilizados (modernos). Com o seguinte raciocínio: se está lá é porque é bom, se não fosse não estaria instalado em um país desenvolvido.

Não trouxe dados estatísticos de segurança, apenas citou exemplos de usinas próximas a residências como o único aval de segurança. Um discurso pouco técnico, mais persuasivo na idéia de convencer sobre os benefícios do investimento.

\section{$\underline{\text { Segundo Expositor }}$}

Foi responsável pela explicação técnica quantitativa sobre a capacidade de gerenciamento do resíduo pela incineração. ou seja. a capacidade de queima diária dos residuos.

\section{Terceiro Expositor}

Levantou a questão sobre a importância da veracidade das informações, acentuando que tudo apresentado pelos empreendedores era comprovado e não suposição. Utilizou um discurso para acusar as ONGs de manipular as informações transmitidas à população. Foi o primeiro expositor a falar sobre a questão das dioxinas. Para dispersar e diluir o impacto desse dado. citou a existência da substância em todo o cotidiano das pessoas. principalmente no cigarro. 


\section{Equipe técnica responsável pelo EIA/RIMA}

\section{Primeiro Especialista - Coordenador da Equipe}

Citou com relativa frequência. intensidade e com certo alarme as condições nas quais encontram-se os "lixões da cidade". Disse que os "lixões" encontram-se em uma situação caótica e sugeriu em sua fala que a solução dos resíduos deva passar por outra solução, não adiantando tentar sofísticar os meios já existentes porque já estão superados.

Com a predominância de uma fala alarmante sobre a situação dos resíduos na cidade. reforçou a necessidade de utilização do incinerador pela grave situação do lixo de São Paulo.

\section{Segundo Especialista - Biólogo}

Contribuiu para reforçar a idéia de que a situação dos residuos é alarmante e caótica. em São Paulo. Expôs que a ocupação inadequada da população. nessas áreas, é o maior risco e problema da região. Um discurso claramante acusativo, reforçando o clima de conflito de interesses, de posiçòes antagônicas, o que mais tarde contribuiria para dificultar ainda mais a busca do consenso.

\section{$\underline{\text { Terceiro especialista - Engenheiro }}$}

Tentou passar que seu discurso era de credibilidade, de honestidade, seriedade e comprometimento com a verdade.

Questionou a credibilidade de alguns grupos ecológicos e disse que era necessário o treinamento de grupos ambientalistas para informar a população de uma maneira adequada. 


\section{Representantes das Entidades Civis}

\section{Primeiro Expositor - Agente Pastoral}

Discurso emotivo. com frases de efeito. deixou clara sua indignação pela situaçào atual dos resíduos e pelos problemas sociais. fora do âmbito da discussão. Mostrou falta de clareza sobre o assunto técnico e o problema em questão. mas usou o seu tempo para um discurso pautado nas carências sociais. Discurso com grande efeito emocional e pouca objetividade. No entanto, não deixou de demonstrar que as carências mais imediatas são as mais visiveis e consequentemente mais importantes. ligadas diretamente à sobrevivencia.

Registrou que os presentes não estavam devidamente informados, o que comprometeria o suposto clima de igualdade proposto para conduzir o debate.

\section{Segundo lixpositor - Associação Ambiental}

A estrutura da Audiencia Pública para esse expositor foi o ponto mais polêmico. Para ele boa parte dos participantes sabe que não ¿ justa a estrutura da Audiència. que cla nào é democrática.

Registrou uma crítica quanto ao tempo escasso destinado para a exposição de todos. fazendo com que muitas pessoas optem por um discurso inflamado e emocionante. obtendo respaldo da platéia e benevolência das autoridades.

\section{$\underline{\text { Terceiro Expositor - Ambientalista }}$}

Reclamou dos moldes do evento. pois para ele não permite a troca. não há espaço para tirar as dúvidas da população. 
Interessante o questionamento sobre o que chamou de "aval cego" dado à ciência e ao que é feito nos países desenvolvidos. sobretudo porque mais adiante fez uso de estudos científicos para endossar sua fala.

Apresentou uma visão mais esclarecida, chegando a questionar os dados trazidos pelos técnicos. Fez uso de um discurso mais analítico, menos político e de menor impacto.

\section{Quarto Expositor - Ambientalista e Membro do CADES}

Sua fala foi iniciada com ressalva sobre seu perfil de ativista e não de uma cientista.

Apresentou um discurso mais conciliador. Apontou falhas tanto nos aterros quanto nos incineradores. Ressaltou o problema dessa tecnologia gerar danos à saúde da população próxima à área de instalação. Posicionou-se contra uma discussão intempestiva.

Seu discurso esteve mais centrado. menos de palanque, apresentando um histórico sobre a reivindicação contra os incineradores que. para ela. não trata-se de um descaso da adminstração do então Prefeito Paulo Maluf. mas algo esperado de uma gestão de direita. que historicamente não tem uma visão de bem estar social.

Foi a primeira pessoa a perguntar para os técnicos sobre o controle da emissão de dioxinas e furanos. Finalizou afirmando ser uma pessoa séria, provocando um diferencial em relação aos outros depoimentos.

\section{Quinto Expositor - Associação de Bairro}

Fez um discurso de oposição à discussão técnica, no entanto com pouco conteúdo. Um discurso populista e de efeito de palanque. Usou o termo castigo para 
aqueles que implantarem os incineradores. Um discurso totalmente centrado na acusação do mal.

\section{Sexto Expositor - Associação de Bairro}

Questionou a legitimidade do evento ao mesmo tempo em que fez um discurso inflamado e consequentemente com poucas informações concretas, baseou-se fundamentalmente na acusação. Em seu discurso prevaleceu a emoção. gerando com isso a comoçào da platéia que respondeu com aplausos.

\section{Sétimo Expositor - Associação de Bairro}

Foi um dos participantes que questionaram a legitimidade da Audiência Pública. Prevaleceu em sua fala uma postura mais política. Acusou a implantação do incinerador de ser algo inerente a governos de direita. que não têm compromisso com o social - discurso politico. Contribuiu para dificultar a negociação. pois as pessoas eram contra o projeto independente de qualquer justificativa, sobretudo pelo fato da gestão que estava querendo implantar o projeto era de direita. No discurso desse expositor, esse dado já era suficiente para a rejeição de um projeto sem legitimidade.

\section{Oitavo Expositor}

Com discurso confuso, iniciou sua fala reivindicando outras coisas. No entanto, registrou sua percepção sobre a falta de espaço para manifestação da comunidade. Reforçou a existência do conflito na relação entre o poder público e a comunidade, um conflito gerado por interesses e posturas explicitamente opostas. 


\section{c) Terceira Parte - Manifestações}

\section{Pessoas Presentes}

\section{Primeiro Manifestante}

Fez reividicação de outras necessidades. na maioria básicas. tais como saúde. educação e emprego. Um discurso claramente emotivo.

\section{Segundo Manifestante}

Levantou uma questão sobre a credibilidade da gestão do prefeito, pois já havia tido outros conflitos com esse mesmo prefeito. Esse registro revela uma barreira para a comunicação.

\section{Terceiro Manifestante}

Uma apresentação com a qual convocou os participantes a posicionarem-se contra as posições da mesa.

\section{Quarto Manifestante}

Registrou a existência de duas posições conflitantes que. para ele. estava prevalecendo o conflito e não a discussão técnica. Reivindicou algo mais científico e menos parcial. expondo que a participação popular estava sendo mera encenação, que os presentes eram apenas espectadores passivos. Concluiu com uma reivindicação pelo poder de decisão. 


\section{Quinto Manifestante}

Iniciou seu discurso ressaltando que não tinha base científica. o domínio das informações técnicas. Afïrmou não confiar nos dados oficiais, para ele a manipulação da informação. Utilizou palavras de ordem, gerando rápida adesão à comoção.

\section{Sexto Manifestante}

Desenvolveu um discurso fortemente apelativo. panfletário e com intensidade religiosa.

\section{$\underline{\text { Sétimo Manitestante }}$}

Radicalmente contra o incinerador, desenvolveu discurso panfletário, pouco consistente e emotivo. Não fez uso de todo o tempo disponivel, dois minutos. afirmando ser uma forma de protesto.

\section{Oitavo Manifestante}

Com uma postura de repúdio ao evento e ao que estava sendo discutido, apenas posicionou-se contrário em um discurso igualmente panfletário e emotivo.

\section{Nono Manifestante}

Dos participantes, foi o primeiro a falar propriamente do problema da incineração e de suas consequências, especialmente das dioxinas. Durante sua fala citou um texto que tratava de incineração. mas não revelou a fonte. Fez um discurso alarmante, acentuando o grau de periculosidade do investimento. Mesmo com a utilização de informações. de dados científicos. concluiu sua fala com uma frase de efeito e foi bastante aplaudido pela platéia. 


\section{Décimo Manifestante}

Fez reivindicação das necessidades básicas da comunidade, principalmente moradia e saúde. pediu que fossem revistas as necessidades mais próximas das carências das pessoas. Falou de dioxinas com palavra de ordem. no entanto. sem entrar em detalhes técnicos.

\section{Décimo Primeiro Manifestante}

Fez sua identificação como médica e desenvolveu uma discussão sob o ponto de vista dos riscos associados à incineração. no entanto. de forma alarmante.

Citou dados alarmantes de contaminação. tais como modificação no sistema reprodutor feminino e masculino. de caráter muitas vezes irreversiveis. Sua fala, como especialista. porém representante do bem. retirou aplausos prolongados da população presente.

\section{Décimo Segundo Manifestante}

Contestou a postura dos técnicos do EIA/RIMA. especialmente por fazerem uso o tempo todo de exemplos extraídos dos países desenvolvidos. apresentados como modelo. Questionou sobre o fato de o padrão de qualidade de vida dos povos dos países ricos não ser aplicado na periferia em questão. Afirmou não acreditar na Audiência Pública como um canal democrático. 


\section{Décimo Terceiro Manifestante}

Usou seu tempo para fazer uma pergunta técnica sobre a existência de estudos comparativos de poluição causada pelos aterros e pela incineração.

\section{Décimo Quarto Manifestante}

Fez um discurso predominantemente político, prevalecendo a dicotomia esquerda e direita. Exigiu que a participação da população fosse mais ativa e não passiva. como estava acontecendo.

\section{Décimo (uinto Manifestante}

Complementou a fala do anterior e afirmou que a solução dos residuos tem de levar em conta a questão metropolitana. não excluindo-a do contexto.

Acentuou mais a parte da legislação em detrimento às explicações técnicas do problema. Fez uma observação crítica e negativa sobre a solução dos problemas pela ciència. principalmente quando essa tenta solucioná-los com um toque de mágica. Fez um discurso equilibrado e sem demagogia.

\section{Décimo Sexto Manifestante}

Disse que o problema deveria ser tratado sem emoção. pois tende a atrapalhar o processo. Alertou os participantes e disse à população para não ser manipulada. especialmente em relação à omissão de dados. informações. Foi um discurso que desagradou a platéia. pois não se enquadrava na fala de manifestação contrária ao projeto. Foi vaiado pelos presentes. especialmente no final quando disse ser a favor da instalação dos incineradores. 


\section{Décimo Sétimo Manifestante}

Já no início de sua fala foi vaiado, assim que se identificou como ex-diretor de compostagem da prefeitura. Esse momento reforça o registro da existência de posições políticas bem definidas. ou seja. quem é governo é contra o povo. A reação ainda auxilia na identificação de idéias já preconcebidas. dificultando o diálogo. a comunicação.

\section{Décimo Oitavo Manifestante}

Em uma fala equilibrada. perguntou sobre a melhor opção. solução para a problemática dos resíduos sólidos domiciliares.

\section{Parlamentares}

\section{Primeiro Parlamentar}

Entre as duas propostas sobre o destino do resíduos. incineradores e aterros. expostos em debate. o deputado defendeu a coleta seletiva. Para ele. ao longo do debate não ficou visível a proposta de coleta seletiva e nem de aterro. que integravam o projeto. Somente teve visibilidade a questão dos incineradores.

Exigiu uma discussão mais ampla e aberta sobre a questão dos resíduos. Fez um discurso político. com efeito de palanque, acusativo e pouco objetivo sobre sua proposta de coleta seletiva.

\section{Segundo Parlamentar}

Começou com um discurso político com base na fragilidade de poder das classes mais baixas. citadas como os pobres. Para ele. a discussão sobre a destinação dos resíduos precisa ser mais ampla. passando pelo comportamento dos consumidores. Firmou o debate do problema na irregularidade do processo de captação de recursos. Praticamente 
ignorou a discussão técnica sobre os incineradores. privilegiando um debate sob o ponto de rista legal.

\section{Terceiro Parlamentar}

Discussão política. de consistència mais frágil em relação ao anterior. BaseouSe nas dicotomias esquerda e direita. periferia e zona sul. interesse público e iniciativas privadas.

\section{Quarto Parlamentar}

Discurso semelhante ao dos parlamentares anteriores. acusou a elite de consumista e de transferir para os pobres a responsabilidade do destino final de seu "lixo". Alimou que a periferia sempre é prejudicada e concluiu sua fala pedindo para que os incineradores fossem instalados proximos da casa do prefeito. Com esse discurso conseguiu retirar aplausos da platéia. terminando sua fala com frases de palanque. mas de pouco esclarecimento para a população.

\section{Quinto Parlamentar}

Apesar do discurso revanchista conseguiu apresentar alguns dados e questionar - EIA RIMA. por exemplo. o processo de análise. Deixou claro que teve de estudar o assunto e que justamente sobre a parte técnica falou-se pouco. gerando com isso conseqüencias para a população.

\section{Sexto Parlamentar}

Levantou a questão do financiamento do investimento, alertando para o fato de que o financiamento iria sobrar para a população. enquanto as empresas apenas lucrariam cada vez mais. Discurso baseado no conflito entre os interesses do prefeito e dos 
vereadores. Questionou a estrutura do evento e que. por falta de tempo. seria impossível um aprofundamento técnico. principalmente no que diz respeito às dioxinas. Registrou que a posição emocional da população deve-se ao fato de ela viver a situação na prática. não precisando defender-se com argumentos técnicos. Disse que é necessário defender o aspecto emocional e alertou os técnicos sobre os cuidados para evitar os erros anteriores.

\section{$\underline{\text { Sétimo Parlamentar }}$}

Pediu seriedade para a discussão, já que o tema era complexo. Chamou a participaçào popular nào como consequência de um processo democrático. mas como pagador de tributos. Questionou mais a administração do então prefeito em detrimento ao questionamento das informaçòes sobre os incineradores. Para ele. a grande questão era a realização de um evento para discutir a implantação do projeto. no entanto com formato mais democrático.

\section{d) Quarta Parte - Réplicas}

\section{Empreendedor}

\section{Primeira Réplica}

Essa fase, destinada a responder perguntas e esclarecer as dúvidas levantadas. teve a participação. intercalada. de dois representantes da equipe técnica responsável pelo EIA/RIMA.

O primeiro especialista disse reconhecer as reivindicações da população. especialmente de suas necessidades básicas. mas que estava lá para esclarecer. tecnicamente. o que foi transmitido. segundo ele. de forma incorreta. 
Respondeu as perguntas técnicas levantadas. tais como emissão de dioxinas e furanos. referçou a segurança do projeto fazendo paralelo com a existência e utilização dessa tecnologia em paises desenvolvidos.

Questionou a forma de utilização e citação dos estudos sobre dioxinas e furanos. realizados pela U.S.EPA. especialmente na fala da médica que. segundo ele. interpretou de maneira equivocada e alarmante aquelas informações científicas.

Falou do beneficio que a instalação do incinerador poderia oferecer para uma região desvalorizada com o aterro sanitário.

Tentou reforçar a segurança do projeto e a garantia de fiscalização pela Cetesb. mencionada como uma conceituada agència ambiental. mesmo diante de um processo de licenciamento que excluía a participaçào dos organismos estaduais.

\section{Segunda Réplica.}

Esse especialista tentou esclarecer dúvidas técnicas. falou da previsão da coleta seletiva como parte integrante do projeto e citou o problema da falta de área para construçào de novos aterros sanitários.

Assumiu uma postura tecnicamente mais agressiva e tentou provar ter dominio tienico do assunto. Tentou responder a todas as perguntas e citações técnicas que foram levantadas.

Exigiu que uma representante de uma ONG de meio ambiente citasse a fonte de uma informação transmitida. especificamente sobre a proibição de construção de incineradores na cidade de Munique. Alemanha. A especialista disse ter feito parte de uma equipe tícnica que debateu a questão da incineração naquela região da Alemanha e que desconhecia os dados transmitidos pela ambientalista. 


\section{e) Quinta Parte - Encerramento}

\section{Secretário do Meio Ambiente}

O Secretário anunciou o encerramento da Audiència Pública e solicitou um pouco de atenção para algumas considerações finais.

Disse que precisava responder as acusações de que estava a favor de uma tecnologia que no passado posicionou-se contrariamente. Justificou que sua posição foi contrária exatamente porque na época não existia o processo de licença ambiental. A partir dessa fala tentou evidenciar a importância democrática da realização de Audiências

Chamou a atenção para o fato de existir diferenças significativas entre os dois momentos. acentuando a idéia de que atualmente o projeto passa pela análise de entidades sérias e isentas. tais como a L'niversidade de São Paulo e a FIPE.

Quanto às agressòes pessoais registradas. o Secretário disse relevá-las em nome da democracia. Para ele. o importante é que na Audiência expressa-se a vontade da sociedade e. assim. sua consideraçào para o acerto do projeto.

O Secretário registrou ainda que sua dedicação ao projeto dos incineradores fundamentava-se na importancia do gerenciamento dos residuos sólidos que. para ele. constituia como o maior problema ambiental de São Paulo.

\section{5 - Análise dos Resultados}

Os dados apresentados nos tópicos anteriores. sobretudo a exposição de alguns momentos da Audiència Pública, revelam inúmeros desafios para a utilização dessas 
Audiências como uma ferramenta de comunicação. visando à democratização do processo de tomada de decisão.

Desta forma. faz-se necessário analisar algumas idéias expressas anteriormente para que sejam identificados os principais obstáculos.

Há evidências da predominância de algumas abordagens e a formação dos seus respectivos discursos. A composição dos principais discursos compreendeu:

a) A demanda por explicações e informações técnicas sobre o empreendimento:

b) As acusações sobre o formato anti-democrático da Audiência:

c) A credibilidade das informações transmitidas pelas diversas fontes.

Em vários momentos da Audiência Pública. que tinha como objetivo apresentar e discutir o EIA/RIMA do incinerador de Sapopemba, foi explorada a discussão acerca das informações técnicas sobre a tecnologia em questão.

Os representantes da equipe técnica responsável pelo EIA apresentaram vários dados e resultados dos estudos sobre a emissão atmosférica dos incineradores. o controle dos gases. dos riscos etc.. Após essa apresentação houve questionamentos com os quais ficou explícita a sensação de desconfiança em relação à veracidade das informações.

No discurso de vários participantes foi revelado um receio em relação a essa manipulação de informações. à possível omissão de dados mais reais sobre os riscos da incineração.

A postura dos representantes de entidades ambientalistas em questionar as eferências bibliográficas utilizadas no EIA/RIMA, sobretudo a ausência da citação de um sstudo realizado pela U.S.EPA, foi um dos exemplos. 
A constatação da importância da disseminação de informações técnicas em Audiências Públicas, mesmo diante de um público não especialista. é fundamental para o resgate de uma discussão iniciada no Capitulo 3, referente à relação de credibilidade entre os diversos atores sociais.

A resposta do público à utilização e citação de estudos científicos, nessa Audiência. desmistifica a idéia de que o problema esteja associado única e exclusivamente à difícil compreensão por parte do público presente, como tem sido comumente propogado tanto na literatura específica. quanto no discurso dos diversos atores envolvidos.

Desta forma. a idéia de que a disseminação de informações técnicas seja a única ou principal barreira para um efetivo processo de comunicação. e consequentemente uma interferência na democratização da tomada de decisão, merece um pouco mais de atençào.

Esse fenômeno demanda uma análise que considere o aspecto da credibilidade do emissor das mensagens. sejam elas técnicas ou não.

Na pesquisa "O que o Brasileiro Pensa da Ecologia". citada no Capítulo 3. foi verificado que há uma maior tendência em as pessoas acreditarem na ciência. mas desconfiarem dos cientistas (Crespo. 1993).

Ao considerar essa constatação. especificamente na análise da Audiência de Sapopemba. compreende-se que os principais conflitos estavam associados a uma percepção negativa dos interesses dos diversos grupos ali representados.

Com base nesse evento não é possivel afirmar que a transmissão de informações técnicas tenha inviabilizado o desenvolvimento de um processo de comunicação mais harmonioso entre as partes. 
Essa discussão compreende o debate presente no item C. referente à questão da credibilidade. Na visão de Berelson e Steiner (1964). esse fenômeno. discutido no Capítulo 3. revela a importância da credibilidade entre os elementos que compõem o processo de comunicação.

As discussões acerca do fenòmeno da credibilidade demandam um cuidado especial. Como visto em Berelson e Steiner (1964). as informações transmitidas por fontes de baixa credibilidade tendem a ser compreendidas como manipulativas. Já as fontes de alta credibilidade podem transmitir uma série de rumores. de inverdades que a tendência da audiência é compreendê-las como verdade absoluta.

Nessa Audiência foi possivel a identificação das entidades ambientalistas e dos politicos de esquerda como fontes de alta credibilidade para aquela comunidade.

Assim. a transmissão de rumores. de informações não confirmadas. de dados por essas fontes tende a ser compreendida e aceita pela comunidade. sem maiores questionamentos.

No entanto, a aparente atribuição de baixa credibilidade aos empreendedores e aos especialistas responsáveis pelo EIA/RIMA, pelo público presente, aparece como um forte obstáculo para a efetiva comunicação entre esses atores.

Se um receptor. um determinado público. posiciona-se com indiferença em relação àquela informação ou à fonte. a comunicação não ocorre ou é prejudicada pelo aparecimento de interferências. de ruidos. Neste caso estudado. pode-se identificar a presença do ruido ideológico (Wrigth. 1975) . ou seja. a interferência que ocorre na relação entre emissor e receptor.

Os especialistas pertencentes a grupos contrários à instalação, portanto. percebidos positivamente pela comunidade. têm suas opiniões. seus dados e informações técnicas mais respeitados. especificamente por essa comunidade. 
$\dot{E}$ importante registrar que uma fonte pode ter credibilidade em relação a uma determinada audiência. pois quem atribui prestígio, confiabilidade a uma fonte é o próprio receptor.

Quanto ao item B. foi visivel a insatisfação dos ģrupos presentes em relação à estrutura da Audiência Pública.

A comunidade se sentiu como elemento passivo diante de um processo que foi idealizado e apresentado como democratizador. mas que pela própria estrutura tem sido compreendido como incompativel com a dinâmica democrática.

As Audiència Públicas têm se distanciado dessa perspectiva e transformado-se em uma arena que registra inumeros conflitos. impossibilitando o respeito à pluralidade do comportamento. dos posicionamentos. das informações inerente às açōes democráticas.

Vários elementos podem ser apontados como responsáveis por essa percepção negativa da sociedade em relação à Audiência Pública. Merece destaque o momento no qual está prevista. no Licenciamento Ambiental. a sua realização. ou seja. em uma situação já avançada. impossibilitando a negociação e a consideração dos anseios da comunidade atingida pela atividade ou empreendimento.

Quanto ao formato, ou seja, à sua estrutura, foram comuns as acusações sobre a disposição de maior tempo para os empreendedores em detrimento a uma disponibilidade menor para a comunidade registrar sua posição.

Essa questão, no entanto. merece ser problematizada com as demais. pois as implicações. os obstáculos que tendem a interferir na tentativa de tornar a Audiência Pública um instrumento de comunicação, uma ferramenta para o processo de tomada de decisão são complexas e precisam de mais investigações. 
A constatação mais preocupante, neste momento da pesquisa. foi a de que a comunidade mais suscetível aos impactos ambientais ou de saúde, que pudessem ser provocados pelo empreendimento. encontrou-se em meio a uma disputa política e a um jogo de interesses que conduziram visivelmente à sua manipulação. 


\section{7 - ANÁLISE DAS REPORTAGENS}

\section{1 - Introdução}

O projeto da Prefeitura de São Paulo. sob a coordenação da Secretaria Municipal do Verde e do Meio Ambiente e com RIMA apresentado em Audiência Pública em 1994. teve repercussão em diversos veículos de comunicação. tais como televisão e jornal impresso.

Ao considerar o volume de reportagens produzido e a quantidade desses veículos de comunicação. optou-se por analisar a cobertura do tema em dois jornais impressos. considerando para isso os critérios mencionados no Capítulo 2 desta pesquisa.

É inegável o poder de ubiqüidade e a importância dos meios de comunicação eletrônicos. especialmente a TV. na sociedade brasileira. no entanto. para o objetivo desta análise. o formato e o tempo disponível para a cobertura jornalistica nesses meios impediriam um estudo mais verossimil do registro da atuação dos diversos atores envolvidos com a temática.

A idéia de analisar a cobertura dos jornais Diário Popular e Folha de S.Paulo está fundamentada na distinção do público que cada veiculo atinge.

Ressalta-se ainda que este estudo não tem como objetivo principal a análise quantitativa da produção de matérias sobre o tema em questão. Quantificar essa produção. com exatidão. no período de 1994 a 2000. em todos os cadernos dos dois jomais. com exceção dos classificados. torna a análise mais suscetível à ocorrência de uma margem significativa de erro.

Desta forma. a exposição do número de matérias selecionadas em ambos jornais fundamenta-se, especialmente, na possivel associação entre o volume dessa 
produção jornalística e o periodo no qual o projeto dos incineradores tinha visibilidade social e. consequentemente. era tratado como um fenômeno midiático.

\section{2 - A Produção de notícias nos jornais Diário Popular e Folha de S.Paulo}

O levantamento da produção de matérias sobre o projeto de instalação das usinas de incineração partiu do ano de 1994. período no qual ocorreu a análise dos Estudos de Impacto Ambiental, em Audiências Públicas. passando pelo periodo de apreciação do projeto pelos órgãos competentes até chegar ao desaparecimento de sua repercussão nos meios de comunicação, sobretudo em decorrência do arquivamento do processo.

No Diário Popular foram apuradas, no periodo selecionado. 31 reportagens e 28 no jornal Folha de S.Paulo. No entanto. a maior parcela dessa produção jornalística ocorreu no ano de 1994 com considerável continuidade no ano seguinte, apontando para um comportamento dos meios de comunicação ainda limitado à cobertura fatual. especificamente na área ambiental.

Segundo Marcondes Filho (1989), a questão maior não é o fato da imprensa realizar uma cobertura meramente fatual e sim o que está por trás da transformação da matéria prima. com a qual os meios de comunicação trabalham. ou seja. a informação, em um produto chamado notícia. Para o autor. esse processo de transformação resulta em visiveis implicações políticas e ideológicas.

Com base nos números apresentados na tabela a seguir é possível, ainda no decorrer desta análise, cruzar algumas informações a fim de identificar uma estreita correlação entre o contexto político e ideológico. que envolvia o fato em questão, e o tipo de abordagem realizada por tais veículos. 
Tabela 10 - Produção de matérias nos jornais Diário Popular e Folha de S.Paulo sobre a instalação de incineradores de residuos domiciliares na cidade de São Paulo.

\begin{tabular}{|c|c|c|c|c|c|c|}
\hline Ano & \multicolumn{2}{|c|}{$\begin{array}{c}\text { Diário Popular } \\
\%\end{array}$} & \multicolumn{2}{|c|}{$\begin{array}{c}\text { Folha de S.Paulo } \\
\%\end{array}$} & \multicolumn{2}{|c|}{$\begin{array}{c}\text { Total por ano } \\
\%\end{array}$} \\
\hline 1994 & 16 & 52 & 14 & 50 & 30 & 50 \\
\hline 1995 & 10 & 32 & 5 & 18 & 15 & 25 \\
\hline 1996 & 1 & 3 & 4 & 14 & 5 & 9 \\
\hline 1997 & 3 & 10 & 2 & 7 & 5 & 9 \\
\hline 1998 & 1 & 3 & 3 & 11 & 4 & 7 \\
\hline Total de Matérias & 31 & 100 & 28 & 100 & 59 & 100 \\
\hline
\end{tabular}

De acordo com os dados acima. constata-se uma incidência maior de matérias no periodo no qual o fenômeno apresentava maior visibilidade social. No jornal Diário Popular. mais da metade das matérias. $52 \%$. foi produzida durante a fase de apresentação do projeto em Audiência Pública. A mesma constatação ocorre com a Folha de S.Paulo. ou seja. $50 \%$ da produção no mesmo periodo.

Houve uma queda considerável da produção de matérias no ano de 1995. No entanto. quando comparado aos anos seguintes. percebe-se que a redução foi menos intensa. Esse periodo é identificado como o momento da aprovação do Estudo de Impacto Ambiental-EIA/RIMA pelo Conselho Municipal do Meio Ambiente e Desenvolvimento Sustentável-CADES.

Nesse periodo, a produção no Diário Popular e na Folha de S.Paulo foi de $32 \%$ e $18 \%$ respectivamente. A explicação para quase o dobro de diferença do primeiro para o segundo jornal pode ser identificada mais adiante quando então for discutido o tipo de abordagem realizada por cada veículo.

A queda da produção de matérias sobre o projeto dos incineradores está associada ao contexto que envolveu a discussão e sobretudo aos interesses dos produtores de notícia. ou seja. as fontes. Como foi discutido no Capitulo 3 deste trabalho, as informações disseminadas pelos meios de comunicação de massa são rápidas e transitórias. Isso significa que outros temas. assuntos, idéias. acontecimentos vêm ocupando o lugar que 
já foi concedido ao debate sobre a então proposta de solução para os resíduos domiciliares em São Paulo.

\section{3 - Fontes de informação}

Considerado o volume da produção jornalística. o próximo passo é observar as fontes mais utilizadas pelos dois jornais. gerando adiante um debate sobre a relação entre o jornalista e suas fontes de informação. entre o tipo de abordagem e a predominância de determinada fonte.

O objetivo principal deste capítulo é identificar o perfil da abordagem. ou seja, os aspectos predominantes na cobertura do projeto de instalação dos incineradores. No entanto. precedendo essa identificaçào. faz-se necessário o mapeamento das fontes de informação utilizadas pelos dois veículos, permitindo com isso uma relação entre o perfil da abordagem e o discurso das fontes mais citadas.

Para melhor identificar a fonte e assim analisar seu discurso, optou-se por um processo de categorização das pessoas, institiuições ou estudos citados nas peças jornalísticas, agregando-os em grupos específicos.

Ressalta-se que a formação desses grupos é inerente ao objeto estudado, não sendo. portanto, nenhum tipo de enquadramento utilizado nas redações dos meios de comunicação. Os jornalistas identificam e checam suas fontes conforme orientação presente nos manuais de redação, produzidos em cada veículo de comunicação. como será discutido ainda neste capitulo.

Assim. com base na análise das 59 reportagens selecionadas nos dois jornais. foram formados oito grupos de fontes. São eles: 
1. Empreendedor: representantes das empresas componentes do consórcio. equipe técnica responsável pela elaboração do EIA/RIMA:

2. Órgãos governamentais - proponentes: representantes da prefeitura de São Paulo. da Secretaria do Verde e do Meio Ambiente. da Limpurb. da Secretaria de Serviços e Obras:

3. Órgãos governamentais - reguladores: representantes do Consema. do CADES, da Cetesb. da Secretaria do Meio Ambiente:

4. Movimentos sociais: representantes da comunidade organizada. de associações de bairros, de moradores do entorno e de religiosos:

5. Organizações não-governamentais: representantes de entidades ambientalistas. sindicalistas etc.:

6. Universidade: representantes da comunidade cientifica nacional $\mathrm{e}$ internacional. de universidades e de institutos de pesquisa:

7. Politicos favoráveis: deputados, vereadores:

8. Políticos em oposição: deputados e vereadores.

Verifica-se que ao grupo Empreendedor foram agregados também os técnicos responsáveis pelo EIA/RIMA. uma vez que boa parte dos argumentos utilizados pelas empresas proponentes baseava-se na fala dos consultores que realizaram o estudo ambiental.

A separação dos representantes dos órgãos governamentais de meio ambiente em dois grupos distintos. como citados acima. está associada ao fato de haver notáveis diferenças entre o espaço nos meios de comunicação conquistado por cada um e. mais visivelmente. o perfil de seus discursos. Esse procedimento de distinção dos grupos de fontes também toi utilizado para as fontes políticas.

Esse mapeamento identificou o grupo Órgãos Governamentais Proponentes como fonte predominante nos dois jornais. No Diário Popular essa categoria de fonte foi utilizada ou citada em $52 \%$ das matérias. Na Folha de S. Paulo o índice foi de $68 \%$. No 
Diário Popular houve uma segunda fonte predominante. Movimentos Sociais. ocupando $61 \%$ do total das matérias selecionadas, não acontecendo o mesmo com o outro veículo.

A tabela abaixo revela a participação de cada grupo de fontes nos dois jornais pesquisados. () registro da incidência de cada grupo dessas fontes conduz a uma análise mais apurada do tipo de abordagem. Os dados expressos a seguir também permitem identificar. excepcionalmente na Folha de S.Paulo. um desnível na participação dos diversos grupos. sendo privilegiada a categoria daqueles defensores do empreendimento.

Entretanto. o jornal Diário Popular concedeu maior visibilidade aos opositores do projeto. sobretudo à comunidade organizada. dando origem à polarização do debate.

Tabela 11 - Incidència dos grupos de fontes de informação no total das matérias pesquisadas.

\begin{tabular}{|c|c|c|c|c|c|}
\hline \multirow[b]{2}{*}{ Classiticaçào } & \multicolumn{5}{|c|}{ Incidência de fontes de intormação } \\
\hline & Diár & $\begin{array}{l}\text { opular } \\
\% \\
\text { rias }\end{array}$ & $\begin{array}{l}\text { Fol } \\
28 \text { I }\end{array}$ & $\begin{array}{l}\text { SP } \\
\% \\
\% \text { rias }\end{array}$ & TOTAL \\
\hline Empreendedores & 4 & 13 & 7 & 25 & 11 \\
\hline Orgãos Governamentais de M.A/Proponentes & 16 & 52 & 19 & 28 & 35 \\
\hline Orgãos Governamentais de $M \Lambda /$ Reguladores & 8 & 26 & 5 & 18 & 13 \\
\hline Movimentos Sociais & 19 & 61 & 4 & 14 & 23 \\
\hline Organizações Não-governamentais & 3 & 10 & 4 & 14 & 7 \\
\hline Universidades & 0 & 0 & 6 & 21 & 6 \\
\hline Politicos favoráveis & 4 & 13 & 3 & 11 & 7 \\
\hline Políticos em oposição & 10 & 32 & 7 & 25 & 17 \\
\hline
\end{tabular}

Com essa divisão das fontes em oito grupos é possivel identificar a formação de três blocos bem definidos de opinião e posicionamento em relação à temática. Assim. as fontes passam a ser identificadas como A) favoráveis: B) neutras e C) desfavoráveis. 
A predominância dos blocos $\mathrm{A}$ e $\mathrm{B}$ sinaliza para a ocorrência de uma cobertura nitidamente dependente das informações disseminadas por fontes com interesses visiveis. uma vez que as fontes neutras obtveram menor participação.

O jornal Folha de S.Paulo explorou mais a utilização de fontes neutras. tais como representantes da comunidade cientifica e dos órgãos de controle ambiental. em relação ao Diário Popular. Verifica-se. no entanto. que a participação da fontes especializadas e neutras foi modesta. A Tabela 12 apresenta a participação desses três tipos de fonte nas matérias pesquisadas.

Os dados a seguir encontram-se mais detalhados nos anexos 2 e 4 .

Tabela 12 - Citação dos três blocos de fontes nas matérias pesquisadas.

\begin{tabular}{|c|c|c|c|c|c|}
\hline \multirow{3}{*}{$\begin{array}{l}\text { Grupos de Fonte } \\
\text { Favoravel }\end{array}$} & \multicolumn{5}{|c|}{ Incidência dos grupos de fonte } \\
\hline & \multicolumn{2}{|c|}{$\begin{array}{c}\text { Diário Popular } \\
31 \text { Matérias } \\
\%\end{array}$} & \multicolumn{2}{|c|}{$\begin{array}{c}\text { Folha de S.Paulo } \\
28 \text { Matérias } \\
\%\end{array}$} & \multirow{2}{*}{$\begin{array}{c}\text { Total } \\
53\end{array}$} \\
\hline & 24 & 77 & 29 & 103 & \\
\hline Destavorável & 32 & 103 & 15 & 53 & 47 \\
\hline Neutro & 8 & 26 & 11 & 39 & 19 \\
\hline
\end{tabular}

A comparação entre os dois jornais pesquisados. no que diz respeito a participação das fontes de informação. revela uma certa semelhança. A diferença. no entanto. ocorre na utilização de fontes cientificas, pela Folha de S.Paulo. visando a uma abordagem menos política e manipulativa.

Isso não quer dizer que os cientistas sejam sempre fontes confiáveis. o que discute-se. no entanto, é a fonte especializada e neutra. $O$ grau de confiabilidade a ser desenvolvido com as fontes especializadas depende da identificação dos interesses de seu discurso e representação. 
A concessão de espaço para pessoas ou instituições neutras confere maior responsabilidade e importância social aos meios de comunicação. pois assim contribuem para a formação de uma sociedade mais bem informada e apta a posicionar-se diante de determinada situação. impedindo que seu posicionamento seja fruto da manipulação das fontes disseminadoras de opinião.

No entanto. a busca pela imparcialidade do jornalista e concomitantemente a de seu veículo de informação tem sido alvo de críticas e debates, não apenas no meio acadêmico. A cultura profissional do jornalista, que sobretudo interfere no critério de noticiabilidade. segundo Wolf (1989), denuncia uma distância entre o que é praticado diariamente nos meios de comunicação e aquilo esperado pela sociedade e fundamental para seu desenvolvimento.

\section{4 - Assuntos Abordados}

A questão ambiental. especificamente o gerenciamento dos residuos sólidos. demanda uma abordagem que considere sua complexidade, sobretudo. suas diversas facetas.

O tema em questão. a implantação de usinas de incineração e sua rejeição pela população, especialmente associada às possiveis implicações ambientais e à saúde pública. foi disseminado pelos dois jornais com pouco cuidado. a partir de uma cobertura que privilegiou a fala das fontes totalmente envolvidas com a questão.

A exploração modesta de fontes pertencentes a grupos neutros. em detrimento às fontes com interesses bem definidos, levou a uma cobertura nociva, sob o ponto de vista da comunicação de riscos ambientais. 
Como discutido no Capítulo 3, deve-se evitar, para uma efetiva comunicação de riscos. a disseminação do medo. a ampliação da angústia diante das incertezas.

A utilização de fontes neutras pela Folha de S.Paulo. apesar de modesta. tentou equilibrar o impacto provocado pela informação das fontes rivais. o que não ocorreu com o Diário Popular.

Para este estudo, a discussão sobre o tipo de abordagem de cada veículo analisado cedeu espaço para um debate considerado aqui mais relevante. a disseminação e simplificação de informações complexas pelas fontes predominantes.

Por informações complexas, no contexto da discussão, identificam-se aquelas sobre as implicações à saúde e ao meio ambiente provocadas pela emissão atmosférica de substâncias tóxicas pelos incineradores. questão disseminada por pessoas ou instituições pouco habilitadas para sua divulgação.

Um exemplo comum foi sobre os danos causados pelas dioxinas e furanos à saúde da população. Com naturalidade as fontes apropriaram-se dessa discussão e ganharam espaço nos meios de comunicação para assim dissemina-las. Essa discussão, no entanto. será retomada mais adiante.

Não houve aqui a preocupação de quantificar os assuntos mais comuns, pois chegar-se-ia em uma discussão maniqueista pouco útil para o objetivo geral do trabalho. Optou-se portanto em verificar a apropriação dessas informações complexas. técnicas ou cientificas por fontes interessadas em seu impacto na sociedade.

Formou-se para isso um grupo de quatro tipos de abordagem que demanda um cuidado em sua disseminação. a fim de minimizar a propagação de rumores, ou seja. de informações que ainda necessitam de apuração. Os grupos são: 
1. Dioxinas e furanos: matérias relacionadas à emissão dessas substâncias pelos incineradores. revelando o perfil polêmico do projeto:.

2. Saúde: matérias que fizeram referência à saúde da população:

3. Meio ambiente: preocupação com o meio ambiente:

4. Riscos: referências aos riscos. perigos ou danos provocados pela incineração.

A Tabela 13 revela a participação desses quatro grupos de abordagem. provocando consequentemente uma discussão sobre as condições de disseminação dessas informações pelas fontes predominantes, ou seja, pelos representantes da Secretaria do Verde e do Meio Ambiente e pela população organizada.

Verifica-se que o grupo das Dioxinas e Furanos apareceu em $42 \%$ das matérias do Diário Popular e em $40 \%$ das publicadas pela Folha de S.Paulo. O grupo Meio Ambiente prevaleceu com $62 \%$ e $58 \%$ nos jornais. respectivamente.

As fontes conduziram também para uma discussão sobre os riscos ou perigos envolvendo a problemática, tendo a frequência de $23 \%$ no Diário Popular e $15 \%$ na Folha de S.Paulo.

Tabela 13 - Incidência das informações mais complexas

\begin{tabular}{|c|c|c|c|c|c|}
\hline \multirow[b]{2}{*}{ Informações } & \multicolumn{5}{|c|}{ Frequència } \\
\hline & \multicolumn{2}{|c|}{$\begin{array}{l}\text { Diário Popular } \\
31 \text { Matérias } \\
\%\end{array}$} & \multicolumn{2}{|c|}{$\begin{array}{c}\text { Folha de S.Paulo } \\
28 \text { Matérias } \\
\%\end{array}$} & Total \\
\hline Dioxinas e Furanos & 13 & 42 & 11 & 40 & 24 \\
\hline Saúde & 9 & 29 & 8 & 29 & 17 \\
\hline Meio Ambiente & 19 & 62 & 16 & 57 & 35 \\
\hline Riscos & 7 & 23 & 4 & 15 & 11 \\
\hline
\end{tabular}

Ressalta-se que, apesar da predominância das discussões políticas e sobretudo da abordagem polarizada. não houve. neste levantamento, a preocupação de seu registro 
detalhado. Objetivou-se, com destaque. discutir a responsabilidade social dos meios de comunicação na transmissão correta das informações.

Antes da apresentação da análise dos resultados obtidos na apuração das 59 matérias jornalisticas. discute-se ainda a possibilidade de amenizar a disseminação de rumores por esses jornais. quando do cruzamento das informações transmitidas pelos grupos de fontes.

O cruzamento ou checagem de uma informação proveniente de determinada fonte é preceito mínimo no jornalismo nas sociedades democráticas. Como boa parte dos jornais possui seus manuais de redação e orientação. sendo a maioria de conhecimento público e apenas uma minoria divulgada única e exclusivamente no ambiente do jornal. foi possivel identificar a menção de tal principio nesses documentos.

O jornal Diário Popular tem um manual de orientação para seus profissionais. mas o uso é restrito à redação do jornal. Assim. fez-se uso das informações expressas no manual de redação do jornal Folha de S.Paulo para verificar se o tratamento à informação. proveniente de um determinado grupo de fonte. atende a critérios ou regras estabelecidos pelo jornal.

O manual citado é um documento público. comercializado em livrarias e bancas de jornais e serve não apenas para os profissionais da Folha de S.Paulo. como também tem sido consultado pelos leitores e por alunos de jornalismo.

As informações apresentadas a seguir foram extraídas do Manual de Redação da Folha de S.Paulo e correspondem a preceitos estabelecidos já na formação acadêmica do profissional de jornalismo, tais como a checagem das informações. o olhar crítico para os interesses das fontes etc.. 
No que diz respeito ao tratamento das fontes. o Manual prevê que cabe ao jornalista determinar o grau de confiabilidade de suas fontes. para que com isso saiba fazer uso adequado das informações por elas transmitidas.

$O$ jornal Folha de S.Paulo identifica a existência de quatro tipos de fontes. demandando cada uma delas procedimento específico, antes de chegar no texto final.

A Tabela 14 apresenta esses dados conforme expressos no manual.

Tabela 14 - Classificação, origem e tratamento das fontes de informações no jornal Folha de S.Paulo.

\begin{tabular}{|c|c|c|}
\hline Classificação & Origens e Caracteristicas & Cuidados e Exigências \\
\hline Tipo zero & $\begin{array}{l}\text { - Enciclopédias renomadas: } \\
\text { - documentos emitidos por } \\
\text { instituição com redibilidade: } \\
\text { - videoteipes. }\end{array}$ & $\begin{array}{l}\text { - Geralmente dispensa } \\
\text { cruzamento: }\end{array}$ \\
\hline Tipo um & $\begin{array}{l}\text { - É a mais confiável quando trata- } \\
\text { se de uma pessoa. } \\
\text { - Tem histórico } \\
\text { confiabilidade; } \\
\text { - Com conhecimento de causa. } \\
\text { está muito próxima do fato que } \\
\text { relata e não apresenta interesses } \\
\text { imediatos na sua divulgação: }\end{array}$ & $\begin{array}{l}\text { - Cruzamento de informação é } \\
\text { recomendável, mas o Jornal } \\
\text { admite a publicação das } \\
\text { informações sem checagem com } \\
\text { outra fonte: }\end{array}$ \\
\hline Tipo dois & $\begin{array}{l}\text { - Apresenta os atributos da fonte } \\
\text { tipo um, com exceção do } \\
\text { histórico de confiabilidade: }\end{array}$ & $\begin{array}{l}\text { - Deve ser sempre cruzada com } \\
\text { pelo menos mais de uma fonte } \\
\text { (do tipo um e dois) antes da } \\
\text { publicação: }\end{array}$ \\
\hline Tipo três & $\begin{array}{l}\text { - A de menor confiabilidade; } \\
\text { - Bem informada, no entanto, } \\
\text { possui interesses (político, } \\
\text { económicos), o que reduz a } \\
\text { confiabilidade: }\end{array}$ & $\begin{array}{l}\text { - pode funcionar apenas como } \\
\text { ponto de partida para a matéria; } \\
\text { - quando não possível o } \\
\text { cruzamento com outras fontes, } \\
\text { ressaltar que trata-se de rumor e } \\
\text { que a informação ainda não foi } \\
\text { confirmada. }\end{array}$ \\
\hline
\end{tabular}

Fonte - Manual da redação: Folha de S.Paulo. 2001. 
Os dados acima não são procedimentos inerentes ao jornal Folha de S.Paulo. caso contrário. os demais veiculos seriam apenas microfones abertos a serem utilizados por diversos interlocutores interessados em um espaço na midia e assim disseminar seus interesses.

Um dado importante deve ser registrado. O surgimento. recente. desses manuais de orientação e a facilidade em acessá-los tendem a conferir honestidade. transparência e responsabilidade às empresas de comunicação. No entanto. a realidade revela uma distância entre o texto do documento e a prática desses veículos.

A tabela abaixo apresenta o cruzamento feito pelos dois jornais pesquisados. Veritica-se que em várias materias foi utilizada uma única fonte de informação. $O$ uso de duas fontes apenas deu origem a uma abordagem com duas nitidas direções. ou seja. sua polarização ou o reforço de uma mesma verdade por duas fontes distintas. mas com idéias e objetivos bem semelhantes. A parcela de matérias com mais de duas fontes. permitindo uma discussão menos polarizada e manipulativa. foi mais baixa.

Tabela 15 - Quantidade de grupos de fontes por matérias pesquisadas

\begin{tabular}{|c|c|c|c|c|c|}
\hline Número de fontes & & $\begin{array}{l}\text { ular } \\
\text { as } \\
\% \%\end{array}$ & $\begin{array}{r}\text { Foll } \\
2\end{array}$ & $\begin{array}{l}\text { aulo } \\
\text { as } \\
0 \%\end{array}$ & Total \\
\hline Uma & 09 & 29 & 10 & 36 & 19 \\
\hline Duas & 15 & 48 & 11 & 39 & 26 \\
\hline Três ou mais & 7 & 23 & 7 & 25 & 14 \\
\hline
\end{tabular}

Os dois jornais, apesar de serem voltados para públicos com perfis distintos. atuaram de maneira relativamente semelhantes. sobretudo no que diz respeito à cobertura meramente pontual e na utilização de fontes comprometidas com interesses específicos.

Há várias explicações para esse fenômeno. podendo destacar o excesso de informação. a velocidade com que os acontecimentos chegam às pessoas. a necessidade de 
reduzir a relação entre tempo e espaço. a relevância da pauta ambiental em detrimento aos acontecimentos políticos. a formação profissional dos jomalistas entre outras.

Para a análise dos resultados obtidos, algumas dessas explicações precisam ser resgatadas.

\section{5 - Análise dos resultados}

Os dados apresentados nos tópicos anteriores conduzem a uma análise não muito favorável ao trabalho desempenhado pelos meios de comunicação. sobretudo. no que diz respeito às questões sobre gerenciamento de riscos ambientais.

É inegável a importância desses veículos na disseminação de questões ambientais. no entanto. alguns ajustes e cuidados precisam ser tomados para que. de fato. a mídia possa desempenhar um importante papel no gerenciamento de questões ambientais.

Dois pontos merecem destaque nesta análise. a cobertura tatual e a utilização das fontes de informação.

A questão da cobertura meramente pontual conduz a uma possivel constatação de que o jornalista depende de suas fontes para compreender determinado fenômeno social como notícia. O projeto de instalação dos incineradores era notícia até as principais fontes o desejarem. Como mencionado no Capítulo 2. foi feito o levantamento até o ano de 2000 e não foi encontrada matéria que fizesse menção a esses incineradores.

Foi encontrado material sobre a problemática dos residuos sólidos. da falta de espaço físico para novos aterros. das limitações em desenvolver uma política de coleta seletiva mais agressiva e abrangente, mas a proposta de instalação dos incineradores não foi mencionada. 
A falta de referência aos incineradores, nos anos de 1999 e 2000. nos jornais pesquisados, faz compreender que os atores envolvidos com a problemática. ou seja, as principais fontes de informação daqueles jornais estão voltados para outros interesses ou perderam forças na luta por um espaço na mídia.

Se a instalação dos incineradores deixou de ser notícia. especialmente pelo arquivamento do processo. o problema da produção de residuos domiciliares e seu gerenciamento continua ainda preocupantes.

Não pretende-se aqui entender que a instalação dos incineradores correspondia à melhor solução para o problema dos rejeitos. a questão é que faltou uma cobertura que excedesse ao fato propriamente dito e que ganhasse um acompanhamento. mas para isso. meio ambiente teria de ter um espaço mais frequente nos meios de comunicação. o que ainda não ocorreu.

Para que uma questão como a do gerenciamento dos residuos seja pauta. independente de uma manifestação social. de um EIA/RIMA. da fala polêmica de um vereador ou secretário, faz-se necessário uma discussão sobre a cultura profissional do jornalista e os interesses sociais dos veículos de comunicação .

As múltiplas facetas que envolvem a problemática ambiental. inclusive a social. não podem ser trabalhadas. ou melhor. moldadas pelas fontes de informação.

O tema especifico demandava um esclarecimento sobre os possiveis riscos ambientais e de saúde provocados pelos incineradores. No entanto. a fuga dos jornais do contato com fontes especializadas, preferencialmente neutras. levou à propagação de rumores. ou seja. de informações ainda não confirmadas ou carentes de explicações mais claras antes de serem publicadas. 
A informação sobre a emissão de dioxinas e furanos, pelos incineradores, até ser confirmada por fontes seguras e neutras. deveria ter sido tratada como um rumor. o que de fato não ocorreu.

O trecho abaixo. extraido de uma das matérias publicadas pelo Diário Popular ilustra bem essa idéia:

..."além de causar câncer. pesquisas recentes demonstram que aqueles compostos (dioxinas) afetam o sistema reprodutor. provocando abortos. má formação de fetos. esterilidade e atrofia dos órgãos sexuais. Também podem provocar retardamento mental e afetar o sistema imunológico" (ver anexo A-15).

A informação disseminada acima. por um dos moradores atingidos pelo projeto e integrante de um movimento contra a instalação dos incineradores. não foi submetida a nenhum cruzamento com outra fonte de informação, pelo contrário. ela foi reforçada com as palavras de um grupo ambientalista.

Na Folha de S.Paulo, no exemplo selecionado. houve uma tentativa de conferir autenticidade à informação, ao fazer uso de duas instituições neutras e de credibilidade, a agència norte-americana de controle ambiental - L.S. EPA. e a Universidade de São Paulo. No entanto. um olhar mais critico demanda por explicações mais objetivas. Como uma instituição pode afirmar algo se não for claramente apresentado seu interlocutor? Quem transmitiu as informações? Onde foram e com quem foram adquiridas?

O trecho então selecionado aponta tal situação (ver anexo B-12):

•Relatório da EPA (Environmental Protection Agency. agência norte-americana responsável pela proteção do meio ambiente). divulgado no ano passado, constatou que os gases que saem dos incineradores causam câncer". Segundo o relatório está comprovada a ligação entre dioxinas e câncer". 
“A Faculdade de Medicina da USP chegou à mesma conclusão da EPA: gases produzidos na incineração causam câncer."

Para Peter Nelson (1994), os jornalistas tendem a evitar as fontes especializadas. impedindo com isso a obtenção de esclarecimentos. o acesso a uma informação mais verossimil. sobretudo. a revelação da existência de divergências e imprecisões cientificas etc.

A manipulação da informação, nos jornais analisados, foi visível a partir da própria predominância das fontes de informação e da identificação de seus interesses durante a análise da Audiência Pública.

Uma das implicações de uma cobertura jornalística pouco atenta à manipulação das informações. e consequentemente propicia à divulgação de rumores. é o fato de a sociedade basear-se nela para nào apenas estar bem informada como também para posicionar-se diante de determinado fenômeno ou situação. Para várias pessoas. os meios de comunicação são a única ou a mais importante fonte de informações ambientais. 


\section{8 - CONCLUSÕES}

Esta pesquisa. que teve como objetivo principal analisar o aspecto comunicacional do gerenciamento de resíduos sólidos em São Paulo. por meio do estudo do projeto de instalação de usinas de incineração. revelou que a comunicação pode ser compreendida como uma importante ferramenta para auxiliar no processo de democratização da tomada de decisão.

A problemática dos resíduos sólidos domiciliares apresenta-se como uma questão complexa por. sobretudo. apresentar um perfil multifacetado. ou seja. seu gerenciamento depende de uma abordagem que observe seu caráter multidisciplinar. suas implicações científicas. politicas. econòmicas. sociais e culturais.

Ao considerar a complexidade que envolve a questão dos resíduos sólidos. pensou-se em analisar a comunicação como uma ferramenta que pudesse viabilizar uma tomada de decisão democrática. sobretudo por atentar-se às diversas implicações provocadas pelo problema.

No contexto do gerenciamento ambiental. tendo como ponto de partida os residuos sólidos. foram então identificadas como possiveis ferramentas de comunicação a Audiência Pública. prevista no Licenciamento Ambiental. e o trabalho desenvolvido pelos meios de comunicação de massa.

A análise dessas duas ferramentas permitiu que este estudo chegasse a algumas conclusões. apresentadas a seguir.

A comunicação tem se revelado como uma importante ferramenta para o gerenciamento das questões ambientais. No entanto. a complexidade que envolve as duas áreas sugere a existência de um vasto campo de pesquisa. 
$\dot{E}$ inegável a contribuição das ferramentas disponiveis de comunicação no cenário ambiental. A atuação dos meios de comunicação de massa. apesar dos interesses subjetivos que muitas vezes representam e do desconhecido impacto de suas abordagens na opinião pública, não pode ser descartada.

Nesta pesquisa foi constatado que a cobertura jornalistica. na área ambiental. ainda apresenta muitas dificuldades. especialmente por revelar uma abordagem simplista e dominada pelos interesses das fontes de informação. Verificou-se ainda. com base na análise. que há pouca investigaçào nessa área, que as questões não são devidamente checadas, disseminando para a sociedade uma série de informações não comprovadas.

Conclui-se com isso que. para entender a atuação dos meios de comunicaçào como ferramenta auxiliar da comunicação de riscos. faz-se necessário eliminar o caráter sensacionalista. pouco investigativo e alarmante de sua cobertura. A geração de medo e angústia. incrementada pela transmissão de informações. é um fenòmeno que tem sido duramente enfrentado. sobretudo em paises que já compreenderam a importância de uma politica oficial de comunicação que possa auxiliar no gerenciamento dos problemas ambientais.

Ressalta-se que não está sendo descartado o trabalho desenvolvido pelos veiculo de comunicação de massa. apenas deve-se reforçar o registro do que pode ser compreendido como função e atuação desses meios.

Neste estudo, que visava a identificar a Audiência Pública e os meios de comunicaçào de massa como possíveis ferramentas de comunicação de riscos. fundamentais para o gerenciamento ambiental. formulou-se três hipóteses que são a seguir resgatadas. 
A primeira hipótese $(\mathrm{H} 1)$ de que “a comunicação de riscos ambientais é comumente interpretada como mera transmissão e tradução de informações técnicas de um público de especialistas para um de não especialistas“ é comprovada nesta pesquisa.

Esta comprovação no entanto. depende da compreensão da idéia expressa anteriormente de que a Audiència Pública seja. não oficialmente. identificada como ferramenta de comunicação de riscos ambientais.

O reconhecimento da Audiência Pública como um instrumento legal que permite a apresentação e o debate sobre os resultados de Estudos de Impacto Ambiental. de novos empreendimentos ou de atividades como um todo. já é sua própria interpretação como processo de comunicação que tende a permitir a participação da sociedade na tomada de decisão.

Essa interpretação é ainda reforçada na Deliberação Consema 50/92. normatizadora da convocação e condução de Audiências Públicas. na qual esses eventos são vistos como arenas que viabilizam o contato entre a comunidade que provavelmente estará exposta aos possiveis impactos ambientais. daquele empreendimento. e aqueles especialistas que desenvolveram o estudo (Ambiente. 2000). Isto leva a concluir que existe uma visão ainda limitada das autoridades competentes frente ao que acredita ser comunicação. ou seja. a simples disseminação de informações entre fonte e emissor com perfis e interesses distintos.

Com base no caso estudado. verificou-se que. apesar de inúmeras exigências e recomendações. o EIA/RIMA da usina de Sapopemba foi aprovado pelo CADES. Resolução 08/1995. sem contemplar as inquietações do público presente na Audiência Pública. especialmente aquelas intensificadas pela propagação de rumores, pela manipulação da informação e pela baixa credibilidade de algumas fontes de informação. 
Essa constatação sugere que o problema maior não é apenas reconhecer. efetivamente, a Audiência Pública como ferramenta de comunicação de riscos, mas sim considerar os fenòmenos nela registrados. Sem essa consideração. por parte do órgão licenciador. por exemplo. pouco será feito para tornar a tomada de decisão mais democrática.

Ainda comprovando essa hipótese. tem sido comum na literatura diversos pesquisadores definirem a cobertura dos meios de comunicação. no cenário ambiental. como o desenvolvimento de um processo de comunicação de riscos.

A Resolução CADES 08/95. por exemplo, ao reiterar a idéia presente no EIA/RIMA que aponta que *a Prefeitura deverá promover ações de educação ambiental utilizando-se dos meios de comunciação para esclarecer a população. em especial a da região. sobre os aspectos ambientais dos resíduos sólidos“(Prodam.2000). revela a comunicação de riscos ambientais como sinonimo da atuação dos meios de comunicação e compreende que sua grandeza está na necessidade e possibilidade do esclarecimento da população.

Como observado no Capítulo 3. comunicação é um processo complexo e não pode ser interpretado. ou melhor. reduzido a simples atividade de transmissão de informações. Nesse último processo. o receptor tende a ser considerado como um sujeito passivo.

A segunda hipótese (H2). que revela que "os principais desafios para uma política eficaz de riscos são a falta de credibilidade entre os atores sociais envolvidos no processo comunicacional e o conflito entre a percepção ou a posição de cada um desses atores em relação aos riscos”. foi parcialmente comprovada.

Essa hipótese deve ser analisada em duas etapas. No que diz respeito à questão da credibilidade. a análise da Audiência Pública revelou. por meio dos discursos dos diversos atores envolvidos, que o problema para a busca de uma 
tomada de decisão democrática fundamenta-se não no fato de as informações técnicas. científicas serem de difícil decodificação pelo público. mas sim na desconfiança em relação aos interesses que cada detentor da informação defende.

Trata-se de um desatio significativo. especialmente porque a atribuição de credibilidade é algo subjetivo, revelando um campo de pesquisa cheio de lacunas. especificamente no Brasil.

A atribuiçào de crédito, de confiança de um público a determinada fonte. por exemplo. ocorre na maioria dos casos quando aquela fonte demonstra maior preocupação com sua audiência. É exatamente nesse momento que a comunidade tende a ser alvo de manipulaçào daqueles que possuem interesses bem definidos. mas que passam a idéia de luta em favor da comunidade.

Esse fenòmeno já é negativo pela própria existència da manipulação. da utilização de estratégias de persuasão. muitas alcançadas pela exploração do emocional.

Quanto à segunda parte da hipótese. afirmou-se ser parcialmente comprovada porque a discussão não conduziu para uma análise das diferenças entre a percepçào de riscos do especialista e dos leigos. No entanto. este estudo promoveu uma discussão sobre os fenòmenos que interferem na percepção das pessoas ou dos grupos sociais.

No modelo esquematizado a partir das idéias de Diaz Bordenave (1986) foi possivel identificar que as pessoas tendem a perceber os diversos fenômenos à sua volta e que essa percepção. em contato com os valores que compõem o repertório de cada um. gera a interpretação.

A partir do estudo de caso, pôde-se verificar indícios significativos de um conflito gerado pela interpretação da atuação de cada um dos atores envolvidos com a 
questão. A maneira como a comunidade percebeu. ou melhor. interpretou a participação do representante do órgão ambiental municipal, dos especialistas que elaboraram o EIA/RIMA. por exemplo. implica diretamente em uma das funções da comunicação, especificamente. a comunhão entre emissor e receptor.

Em relação à terceira hipótese (H3). "a audiência pública e os meios de comunicação podem ser duas importantes ferramentas auxiliares para a democratização do processo de tomada de decisão“. pode-se afirmar que mais estudos precisam ser desenvolvidos nesse campo a fim de levantar e analisar um volume maior de informações sobre a utilização das audiências públicas e dos conteúdos midiáticos, especificamente na área ambiental.

A demanda de mais pesquisas nessa área taz-se necessária. especialmente. a partir da constatação que o caso aqui estudado seja atípico. no qual o proponente. a Secretaria do Verde e do Meio Ambiente. foi simultaneamente. por meio do CADES, o órgão licenciador.

Pode-se afirmar que a idéia que se tem da importância da cobertura dos meios de comunicação. na área ambiental. foi revelada apenas no documento "O que o Brasileiro Pensa da Ecologia“ (Crespo. 1993) realizado às vésperas da Rio ‘92. Fazse necessário, portanto. um estudo mais recente para identificar o grau de importância desses veículos na formação de uma sociedade mais informada ambientalmente.

Esta pesquisa conclui que mais estudos precisam ser desenvolvidos sobre as possiveis ferramentas de comunicação. seus perfis e atuações para melhor compreender a importância da comunicação no processo de gerenciamento ambiental.

Não é possivel negar os fortes indícios que apontam para a importância tanto da Audiência Pública quanto dos meios de comunicação para o auxílio de um debate sobre meio ambiente que leve em consideração os anseios, as idéias e informações dos mais variados atores sociais. 
Compreende-se a importància desta pesquisa como o ponto de partida para a compreensão da comunicação de riscos ambientais como um instrumento a ser adotado pelos órgãos competentes de meio ambiente, estabelecendo com isso procedimentos mais éticos e próximos da realidade brasileira.

\section{1 - Recomendações}

Diante dos resultados obtidos nesta pesquisa e da complexidade da temática. apresenta-se uma série de recomendações que visa. sobretudo. ao reconhecimento da comunicação como um importante instrumento da política ambiental.

Compreender a importância da comunicação, no cenário ambiental. demanda o abandono de preconceitos concebidos a partir da idéia simplista que identifica a comunicação como o resultado do trabalho desenvolvido pelos meios de comunicação de massa.

Desta forma. recomenda-se que:

- A comunicação, especialmente no cenário ambiental, seja compreendida. analisada e estudada como uma ciência. com suas características e complexidade.

- A comunicação de riscos ambientais seja legitimida pelas autoridades competentes e que possa se integrar às etapas necessárias para o licenciamento com avaliação de impacto ambiental. 
- As autoridades competentes reconheçam e utilizem a comunicação para o desenvolvimento de políticas ambientais mais participativas.

- Sejam realizados estudos sobre comunicação de riscos ambientais que considerem as especificidades brasileiras.

- Sejam elaborados. pelas autoridades ambientais. em conjunto com a universidade. alguns procedimentos para o registro e análise dos aspectos comunicacionais de um processo de licenciamento com avaliação de impacto ambiental.

- As Audiências Públicas sejam oficial e mais diretamente reconhecidas como ferramentas de comunicação de riscos. fundamentais para a democratizaçào do processo de tomada de decisão.

- As autoridades competentes. diante do processo de aprovação de EIA/RIMA. contemplem em suas exigências e recomendações não apenas aspectos técnicos do projeto. mas também a ansiedade $\mathrm{e}$ incerteza da comunidade, especialmente gerada pelos problemas comunicacionais.

- As autoridades recorram não apenas à ata das Audiências Públicas, mas também ao registro na integra de seu desenvolvimento, a fim de mapear os conflitos e implicações comunicacionais mais comuns para assim. criar instrumentos que possam minimizá-los.

- A estrutura das Audiências Públicas seja revista. considerando a necessidade de que sua realização seja precedida por reuniões técnicas informativas que possam analisar, por etapa, o desenvolvimento do EIA e considerar a possivel formação rumores e conflitos. 
- Diante de projetos mais polêmicos. como no caso dos incineradores. seja realizada mais de uma Audiência Pública. permitindo que as questões mais complexas sejam melhor analisadas pelos diversos atores envolvidos. o que já está previsto na Resolução CONAMA 9/87.

- A presença de comunicadores sociais na equipe técnica responsável pelo EIA/RIMA seja reconhecida pelas autoridades competentes e pelos empreendedores e que as observações desses especialistas. especificamente sobre os fenômenos relacionados à comunicação. sejam contempladas no estudo.

- Sejam desenvolvidas novas pesquisas sobre a percepção dos problemas ambientais pela sociedade brasileira.

- Sejam desenvolvidos estudos sobre a percepção das autoridades ambientais pela sociedade brasileira, revelando com isso o grau de credibilidade que a população atribui aos órgãos de controle ambiental.

- Os órgãos ambientais. por meio de pesquisas. investigue o aspecto comunicacional das Audiências Públicas.

- A atuação da mídia seja acompanhada criticamente e que as informações divulgadas sejam utilizadas com mais cautela.

- O jornal de bairro. voltado especialmente para a cobertura de acontecimentos locais. seja estudado pelas autoridades competentes como um instrumento a ser explorado durante o gerenciamento de problemas ambientais. 


\section{9 - REFERÊECIAS}

[ABNT] Associação Brasileira de Normas Técnicas. NBR 10004. Esta norma fixa condições para a classificação de residuos sólidos. [on line] disponível em $<$ http: Ilwww.abnt.org.br/serviços.htm> Acesso em : 15/08/2000.

Alport G. e Postman L. Psicologia del Rumor. Ed. Psique. B. A.

Amado G. e Guittet A. A dinâmica da comunicação nos grupos. $2^{\mathrm{a}}$. Rio de Janeiro: Zahar Editores, 1982.

Ammann SB. Participação social. São Paulo: Cortez e Moraes. 1978.

Ayres JRCM. Sobre o Risco - Para Compreender a Epidemiologia. São Paulo: Editora Hucitec, 1997.

Barbero JM. Dos meios às mediações. Rio de Janeiro: UFRJ Editora. 1987.

Barros Filho C. Ética na Comunicação - da informação ao receptor. São Paulo: Moderna, 1995.

Beltrão L e Quirino N. Subsídios para uma Teoria da Comunicação de Massa. São Paulo: Summus, 1986.

Beck U. Risk society. London: SAGE Publications, 1992.

Berelson B. e Steiner G. Human behavior. New York: Holt, 1964.

Berlo DK. O Processo da Comunicação - Introdução à Teoria e à Prática. São Paulo: Martins Fontes, 1999.

Brasil. Lei Federal $N^{0}$ 9605, de 12 de fevereiro de 1998. Dispõe sobre as sanções penais e administrativas derivadas de condutas e atividades lesivas ao meio ambiente, e dá outras providências. [on line] disponível em http//www.planalto.gov.br/CCIVIL/Leis/L9605.htm (1999 out.) 
Burns W, Slovic P, Kasperson RE, Kasperson J, Renn O, Emani S. Social amplification of risk: na empirical study. Carson City: Nevada Nuclear Waste Project Office. 1991. (NWPO-SE-027)

[CADES] Conselho Municipal do Meio Ambiente e Desenvolvimento Sustentável. Resolução n. 08 de 13 de janeiro de 1995 que dispõe sobre a aprovação do EIA/RIMA do incinerador de Sapopemba. [on line]. Disponivel em $<$ www.prodam.sp.gov.br/suma/cades/resolucoes.htm] Acessado em 29/12/2000.

Calderoni S. Os bilhões perdidos no lixo. Ed. Humanitas. São Paulo, 1997.

[Cetesb] Companhia de Tecnologia de Saneamento Ambiental. Introdução à análise de risco. São Paulo. 1994.

[Cetesb] Companhia de Tecnologia de Saneamento Ambiental. Inventário Estadual de Residuos Sólidos Domiciliares. Janeiro de 1999. Diário Oficial do Estado de São Paulo. Suplemento. São Paulo. 20 abr 1999. Seção $1 .$.

Chaparro MC. Um modelo jornalístico de divulgação da ciência. In: Revista Brasileira de Comunicação - Intercom, 1990.

Chess C. Evaluating public participation efforts: Methodological issues. A review of the methods used to evaluate public participation programs. 1999.

Cohn $G$ (org.) Comunicação e indústria cultural: leitura de análise dos meios de comunicação na sociedade contemporânea e das manifestaçóes da opinião pública, propaganda e "cultura de massa" nessa sociedade. 2a. São Paulo: Companhia Editora Nacional, 1975.

Combs B. Slovic P. Newspaper coverage of causes of death. Journalism Quarterly, 1979: $56: 837-843$

Commoner B.: Shapiro K. and Webster T.; The origin and health risks of PCDD and PCDF. Waste Management and Research, Vol. 5 (327-346), 1987.

[CONAMA] Conselho Nacional de Meio Ambiente. Resolução n. 09, de 03 de dezembro de 1987. Define a finalidade da realização da Audiência Pública e os critérios para sua solicitação. [on line] Disponivel em <http://www.ambiente.sp.gov.br> Acesso em: 05/01/2001. 
[CONSEMA] Conselho Estadual de Meio Ambiente. Deliberação 50/92. [on line]. Disponivel em <www.ambiente.sp.gov.br> Acesso em 05/01/2001.

Covello VT e McCallum. Effective Risk Communication - The Role and Responsability of Government and Nongovernment Organizations. Plenum Press. New York, 1989.

Covello VT. Menkes J. Mumpower J. Risk evaluation and management. New York: Plennum Press. 1984.

Covelo VT, McCallum DB. Effective risk communication. New York: Plenum Press, 1989.

Crespo S e Leitão P. O que o Brasileiro Pensa da Ecologia. Rio de Janeiro. MAST, CNPq, 1993.

De Fleur, M. L. Teorias da comunicação de massa. 2a. Rio de Janeiro: Zahar, 1976.

Diaz Bordenave JE. Além dos meios e mensagens: introdução à comunicação como processo, tecnologia, sistema e ciência. 2a. Petrópolis: Vozes, 1986.

Dixon B. Para que serve a ciência?. 2ª São Paulo: Cia. Editora Nacional, 1976.

Doderlein JM. Risk and decisions: introduction. In: Singleton WT, Hovden J. Risk and decisions. Chichester. John Wiley \& Sons, 1987. P. 1-8

Duston TE. Recycling Solid Waste. London. Quorum Books. 1993.

Eco U. Apocalípticos e Integrados. 5. São Paulo: Perspectiva, 1998.

Emery E. Introdução à Comunicação de massa. São Paulo. Atlas, 1973.

Fausto Neto A. Comunicação e Mídia Impressa - Estudo sobre a AIDS. São Paulo: Hacker Editores, 1999.

Fayard P. A comunicação científica pública. Liyon: Chr. Soc., 1988. 
Ferreira LC. A questão ambiental: sustentabilidade e políticas públicas no Brasil. São Paulo: Boitempo Editorial. 1998.

Freudenberg N. Not in our backyards! New York: Monthly Review Press, 1984.

Fritzen S. Treinamento de Lideres Voluntários. Petrópolis: Vozes. 1987.

Folha de S.Paulo. Manual de redação: Folha de S.Paulo/-São Paulo: Publifolha, 2001 .

Foratini OP. Ecologia, epidemiologia e sociedade. São Paulo: EDUSP, 1992.

Gadomska M. Risk Communication. In: International Conference on Radiation and Society: Comprehendig Radiation Risk. Paris (France) 24-28 oct. 1994. Editor IAEA: July 1994; Proceding Series p. 147-166

Gonçalves CL. Definindo a questão do lixo urbano. In: Consumo, lixo e meio ambiente. Publicação do CEDEC em Parceria com a Secretaria do Meio Ambiente e Coordenadoria de Educação Ambiental. São Paulo, 1997 (set). p. 3.

Grinberg MS (org.). A comunicação alternativa na América Latina. Petrópolis: Vozes. 1987.

Guareschi PA. Os construtores da Informação - Meios de comunicação, ideologia e ética. Petropolis, RJ. 2000.

Hansen A. Mass Media and Environmental Issues. In: International Workshop on Environmental Journalism. University of Bradford. England, 28-30 april, 1995.

IBGE FUNDAÇÃO. Censo Demográfico: famílias e domicílios: São Paulo. 1996. [on line] Disponivel em IPT/CEMPRE - Lixo municipal: manual de gerenciamento integrado. São Paulo,
IPT, 1995. 
Jacobi P. Desperdicio e degradação ambiental. In: Consumo, lixo e meio ambiente. Publicação do CEDEC em Parceria com a Secretaria do Meio Ambiente e Coordenadoria de Educação Ambiental. São Paulo, 1997 (set). p. 12-13.

Jovchelovitch S. Representações Sociais e Esfera Pública - A construção simbólica dos espaços públicos no Brasil. Petropolis, RJ, 2000.

Krimsky S e PLOUGH A. Environmental Hazards - Communicating Risks as a Social Process. Auburn House Publishing Company, 1988.

Kunczik M. Conceitos de Jornalismo - Norte e Sul. São Paulo: Edusp, 2001.

Lima LC (org.). Teoria da cultura de massa. 3a. Rio de Janeiro: Paz e Terra, 1982.

Loomis CP e Beagle JA. Rural Sociology: the Strategy of Change. Prentice Halol. 1957.

Lopes DF at al. A Evolução do Jornalismo em São Paulo. São Paulo: Edicon. 1998.

Luhmann N. Ökologische Kommunikation - kann die moderne Gesellschaft sich auf ökologische Gefährdungen einstellen? . 2a. Opladen: Westdeutscher Verlag, 1988.

Lupton D. Risk as moral danger: the social and political functions of risk discourse in public health. In: International Journal of Health Services. Baywood Publishing Co. Volume 23, páginas 425-435. 1993.

Marcondes FC. O capital da notíca - jornalismo como produção social da segunda natureza. São Paulo: Ática. 1989.

Mattelart A. A Globalização da Comunicação. Bauru. SP: EDUSC.

Medina CA. Profissão jornalista: responsabilidade social. Rio de Janeiro: Ed. Forense-Universitária, 1982. 
Menezes CL. Desenvolvimento Urbano e Meio Ambiente: a experiência de Curitiba. São Paulo: Papirus. 1996.

Miége B. O Pensamento Comunicacional. Petropolis. RJ. 2000.

Miller P. Agency communication. community outrage. and perception of risk. In: Risk Analysis. 1993.

Morin E. Terra Pátria. Porto Alegre: Sulina. 1995.

Moraes ACR. Meio ambiente e ciências humanas. São Paulo: Hucitec. 1994.

Pfromm Netto S. Comunicação de Massa: natureza, modelos, imagens; contribuição para o estudo da psicologia da comunicação de massa. São Paulo, Pioncira. 1972.

Velson P. Dez Dicas Práticas para Reportagens sobre o Meio Ambiente. Virginia. Center for Foreign Journalists. 1994.

Neotli C. A nova ordem da informação e da comunicação. Petrópolis: Vozes, 1986.

Vylan I.G. Risk perception in Brazil and Sweden. Stockholm: Center for Risk Research: 1993. (RIHZIK()N Report. 15)

Niessen WR. Combustion and incineration processes: applications in environmental engineering. 2". New York: Marcel Dekker. 1995.

ONU -- Organização das Naçòes Unidas. Comissão Mundial sobre Meio Ambiente e Desenvolvimento - Nosso Futuro Comum. Rio de Janeiro. 2a edição, Editora da Fundação Getúlio Vargas. 1991.

Pasquali A. Compreender la Comunicación. 2a. Monte Avila Editores. Caracas, Venezuela, 1980.

Penteado JRW. A Técnica da Comunicação Humana. Livraria Pioneira Editora. $8^{\mathrm{a}}$. São Paulo, 1982. 
Peruzzo CMK. Comunicação nos Movimentos Populares - a participação na construçào da cidadania. Petrópolis: Vozes, 1998.

PRODAM. [on line] Disponível em <http//:www.prodam.sp.gov.br/limpurb>. Acesso em: 29/12/2000.

Rayner S. Cultural theory and risk analysis. In: Krinsky S, Golding D, editors. Social theories of risk. London: Praeger, 1992. p. 53-79.

Renn O. Risk Communication: Towards a Rational Discourse with the Public. In: Journal of Hazardous Materials. 29 (1992), p. 465-519.

Romanzini G. et al. Comunicação e Controle Social. Petropolis, RJ, 1991.

Rubim AAC at al. Produção e recepção dos sentidos midiáticos. Petropolis: Vozes, 1998.

Sandman P.e Weinstein N. Communications to reduce risk underestimation and overestimation. In: Risk Decision and Policy, 1998, Vol. 3, N. 2. Review of a series of studies,most dealing with radon, that compares various techniques for communicating risk.

Sandman P. e Weinstein N. Some Criteria for Evaluating Risk Messages. In: Risk Anaysis. Vol. 13, n 1, 1993.

Sandman P. e Miller P. Agency Communication. Community Outrage, and Perception of Risks: Three Simulation Experiments. In: Risk Analysis, vol. 13, $\mathrm{n}^{\circ} 6$, 1993.

Santos SL. \& Edwards S. Comparaive Study of Risk Assessment and Risk Communication Practices In: Western Europe; a report prepared for the German Marshall Fund of the United States. May, 1990.

Santos, S.L. \& McCallum DB. Public Knowledge and Attitudes of Chemical Risks in Six Communities. A Report of a Followup Survey, Columbia University Center for Risk Communication, September, 1993. 
São Paulo. Lei Estadual N. 9509, de 20 de março de 1997. Dispõe sobre a Política Estadual do Meio Ambiente. seus fins e mecanismos de formulação e aplicação. [online] Disponível em http.//www.ambiente.sp.gov.br/lei_decretos/lei9509.htm. (23/04/2000).

SÃO PAULO (S.P.). Secretaria Municipal do Verde e do Meio Ambiente. Audiência Pública sobre o Estudo de Impacto Ambiental e respectivo Relatório de Impacto Ambiental da Usina de Processamento de Residuos Sólidos Domiciliares com Incineração. Recuperação de Energia e dos Materiais Reaproveitáveis de Sapopemba: notas taquigráficas. São Paulo: Câmara Municipal, 1994. não paginado.

Shrader-Frechete K. Risks and Ethics. In: International Conference on Radiation and Society: Comprehendig Radiation Risk. Paris (France). 21-28 oct. 1994. Editor IAEA. July 1994: Proceding Series p. 167-182.

Sirvinskas LP. Tutela Penal de Meio Ambiente - Breves considerações atinentes à Lei n. 9605 de 12/02/1998. São Paulo: Saraiva, 1998.

Sjöberg L. Risk Perception. In: International Conference on Radiation and Society Comprehending Radiation Risk. Paris, 27-28 oct. 1994. IAEA. July 1994. Proding Series. p. 29-59.

Sjöberg L. Risk Perception and Credibility of Risk Communication. Stockholm: Center for risk research, 1992. Report. $N^{\circ} 9$. p. 1-25

Sjöberg L. Perceived risk vs. Demand for risk reduction. Stockholm: Center for Risk Research: 1994b. Report Nº 18.

Slovi P. Perceived Risk, Trust and Democracy. Risk Analysis. Vol. 13, nº 6, 1993.

Slovic P. Perception of risk: reflections on the psychometric paradigm. In: Krinsky S, Golding, D, editors. Social theories of risk. London: Praeger, 1992. P. 117-52

Sobral HR. Aspectos Locacionais do Gerenciamento e Comunicação de Riscos Ambientais de Atividades Industriais. In: Seminário Internacional sobre Gerenciamento e Comunicação de Riscos Ambientais. São Paulo. Fundacentro, 1995. 
Sobral HR. O meio ambiente e a cidade de São Paulo. São Paulo: McGraw-Hill, 1996.

Stern P. e Fineberg H. Understanding Risk - informing decision in a democratic society. Washington: National Academy Press, 1996.

Tálamo MFGM et al. Informação: do tratamento ao acesso e utilização. In: Comunicação e Educação. São Paulo, set. 1994. (1): 15 a 20.

Teixeira MAC, Carvalho VS. Segura DS. Produção e destino do lixo na Região Metropolitana de São Paulo. In: Consumo, lixo e meio ambiente. Publicação do CEDEC em Parceria com a Secretaria do Meio Ambiente e Coordenadoria de Educação Ambiental. São Paulo, 1997 (set). p. 4-6.

Thompson J. B. A mídia e a modernidade - uma teoria social da midia. Petrópolis: Vozes, 1998.

Viá SC. Formação de recursos humanos: a comunicação nas questões ambientais propostas de ensino e pesquisa. In: Comunicação e Sociedade. Ano XI, n. 19, março, 1993.

Willen. O urbano. In: Diálogos Impertinentes. PUC. TV Cultura. 1997.

Willis J e Okunade AA. Reporting on Risks - The Practice and Ethics of Health and Safety Communication. Westport: Praeger Publishers, 1997.

Wright C. Mass Communication: a sociological perspective. New York: Random House, 1975. 
Anexo 1 - Cópia das matérias publicadas no jornal Diário Popular (1994 a 1998)

Ordem Cronológica 


\begin{tabular}{|l|}
\hline DATA \\
\hline $27 / 04 / 94$ \\
\hline $24 / 05 / 01$ \\
\hline $29 / 05 / 94$ \\
\hline $09 / 06 / 94$ \\
\hline $16 / 06 / 94$ \\
\hline $30 / 06 / 94$ \\
\hline $29 / 07 / 94$ \\
\hline $08 / 08 / 94$ \\
\hline $26 / 08 / 94$ \\
\hline $28 / 09 / 94$ \\
\hline $28 / 09 / 94$ \\
\hline $24 / 10 / 94$ \\
\hline $26 / 11 / 94$ \\
\hline $30 / 11 / 94$ \\
\hline $01 / 12 / 94$ \\
\hline $09 / 12 / 94$ \\
\hline $05 / 01 / 95$ \\
\hline $06 / 01 / 95$ \\
\hline $14 / 01 / 95$ \\
\hline $26 / 01 / 95$ \\
\hline $15 / 03 / 95$ \\
\hline $10 / 04 / 95$ \\
\hline $06 / 06 / 95$ \\
\hline $09 / 06 / 95$ \\
\hline $25 / 08 / 95$ \\
\hline $05 / 12 / 95$ \\
\hline $20 / 04 / 96$ \\
\hline $11 / 05 / 97$ \\
\hline $26 / 12 / 97$ \\
\hline $26 / 12 / 97$ \\
\hline $30 / 09 / 98$ \\
\hline
\end{tabular}

\begin{tabular}{|l|}
\hline \multicolumn{1}{|c|}{ TÍTULO } \\
\hline Incinerador \\
\hline Usina de lixo será feita no parque Anhanguera \\
\hline Usina de incineração de lixo causa Protesto \\
\hline Moradores levam prato de lixo para secretário \\
\hline Maluf quer incineradores de lixo em toda cidade \\
\hline Usina de incineração de lixo causa protesto \\
\hline O cartel do lixo na cidade \\
\hline O lixo e a demagogia \\
\hline Secretário Promete resolver problema do lixo com usinas \\
\hline Zona Leste recusa combustão de lixo \\
\hline Protesto contra usina despeja lixo na Câmara \\
\hline Moradores contra incineradora de Maluf \\
\hline Protesto marca audiência sobre usina de lixo \\
\hline Incinerador \\
\hline Moradores protestam contra lixo \\
\hline Prefeitura mantém aterro e usina de lixo em Perus \\
\hline Adiada votação de relatório sobre incineradores de lixo \\
\hline Protesto contra incineradores \\
\hline Cades aprova instalação de incineradores de lixo \\
\hline Manifestação critica usina de lixo na região de perus \\
\hline Moradores entram na justiça contra incineradores de lixo \\
\hline São Mateus protesta contra incinerador \\
\hline Manifestação rejeita incinerador de lixo \\
\hline Incineradores de lixo são idéia da gestão Erundina \\
\hline Justiça suspende desapropriação de área em Perus \\
\hline Moradores abrem guerra contra incinerador de lixo \\
\hline Zona sul e leste vão ganhar incineradores \\
\hline Justiça libera obras de usinas incineradoras \\
\hline Incineradores deixam população revoltada \\
\hline Zulauf diz que cumpre a lei \\
\hline Falta de aterro para lixo ameaça capital \\
\hline
\end{tabular}




\section{- Incinerador}

O vercador Henrique Pacheco (PT) está querendo que o sccretário municipal de Obras, Reynaldo de Barros, participe de uma audiência pública para juslificar a instalação de um incinerador de lixa $\mathrm{cm}$ Sào Mateus, "Pedi explicações por escrito à sccretaria, mas eles se limitaram a falar das enormes vantagens do incinerador. Ora, sc a coisa $\dot{c}$ tào boa, porque nào o instalam na rua Costa Rica?". pergunta. 


\section{Usina de lixo será feita no parque Anhanguera}

Duas árcas particulares que somam $436.771 \mathrm{~m}^{2}$ no parque Anhanguera, na Zona Oesle da cidade, serào desapropriadas pela Prefeilura para a inshalaçio de usina de compostagem, cmIreposto e incinerador de lixo. $O \mathrm{dc}$ creto de utilidade pública foi publicado no Diário Oficial do Municipio de ontcm.

Uma das arcas, provavelmente a maior, scrá usada para a implanlaçào da usina, cntreposto $c$ incinerador de composto orgánico. $A$ oulra vai ser incorporada ao ecreno do parque Anhangucra.

O projcto, que foi claborado por Iécnicos da Secretaria Municipal do Verde e do Mcio Ambiente, estí pronto desde abril deste ano. $\Lambda$ inten-
Cio $c$ Iransferir as aproximadamente 1.100 loncladas de lixo processado na usina de Vila Lcopoldina.

"A instalação da usina nào vai compromicicr o praryuc c os morndo. ies da Vila Leopoldina scrajo bencfi. ciajos", afirmou o secretário do Verde c do Mcio Ambiente, Werner Zulauf. O custo aproximado da usina $c$ do incincrador É de USS 150 niilhòcs.

O vereador Roberto Tripoli (PV) alirmou cm abril que o projelo terá de ser debatido $\mathrm{cm}$ audiéncias publicas na Cämara Municipal. Na scmuna , assada, Tripoli denunciou que a Preleilura já eslava jogando composto de lixo cri uma arca do parque Anlian. fucril c promelcu recorrer ao Ministe. ino Público. 


\section{Usina de incineração de lixo causa protestó}

Revoltados com a instalacio de lima usina de incincraçào de lixo no Jardim Sío Francisco, aproximata. mence 400 moradores da regian lolarim o largo Simla Adélia, em Sio Malcus, Zoun Leste cm prolestocon-

ril 0 projcto dia Prefcilura Os mumi.

cstantes usaram miscings cslanics usarim masciras antipolu. sion. para denunciar o perigo que a usina representa a satude da popula sian, ce carregando fairiss c cambes gritavom nio queremos o lixio, so satude c habitaço

Durante a nunifestilçio, os monta-

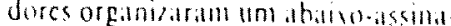
do para lentar impedir a installacion dit usina, que estia orsiddia em LISS Is mi.

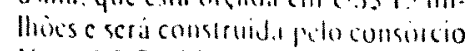

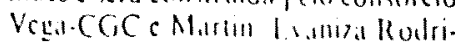




\section{Moradores ley am prato de
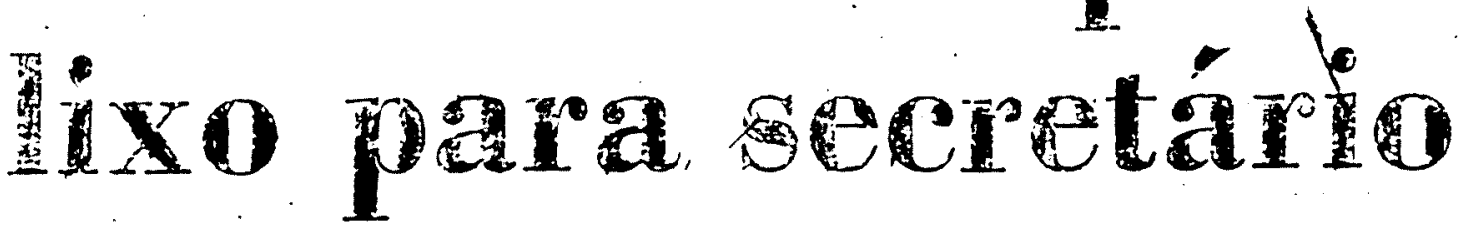

Mindorerde Pritue Pirituhd pro-

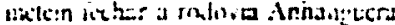
no diz!5. is 15h. cn: protsto contrs

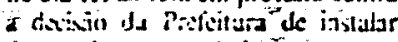

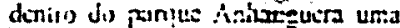
- usina c una incincrabur be lixo. Ein manfostacana natraco do Conjunto A'scionsil na arenita Patilists. onde fukiona a Sersiaia .luniopal do

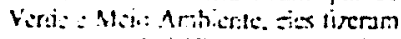

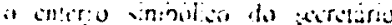

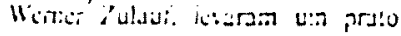

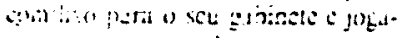

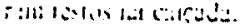

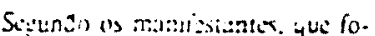

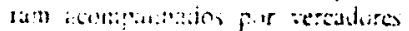

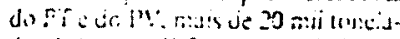
A

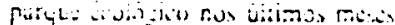

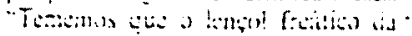

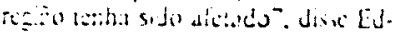

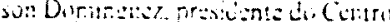

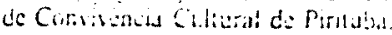

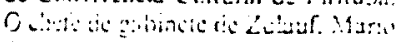

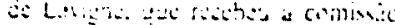

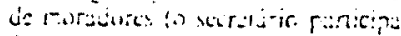

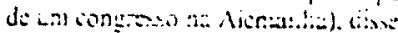

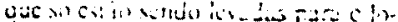
zal -

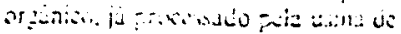

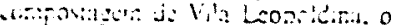
4. $\sin 2 \sin$

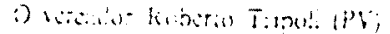

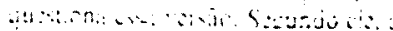

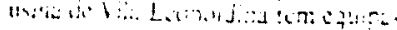

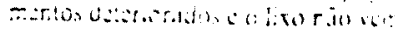

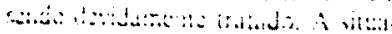

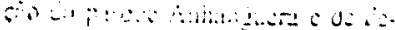

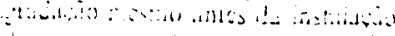

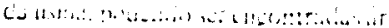

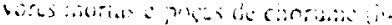

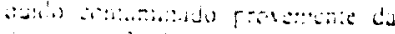

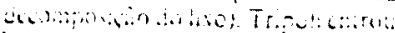
6) 5 :

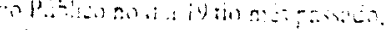

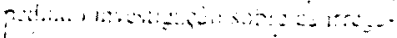

tomates
A riviur preneuphio doimado

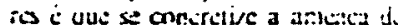
irsusfonnar a 2 aca na Control do ! xo d: Sijo Prelo. que rextatia diaria.

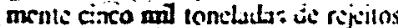
d: incinersdiores que seric instsiados en Sinto Aṽaro e Sio Matets. secundo o veruvior Adrüs Dioro

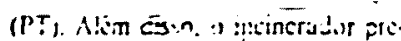

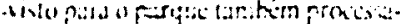

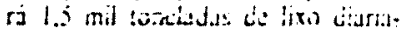

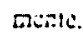

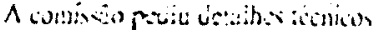
sobre " piojets. mas Lavene Jisic

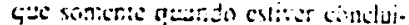

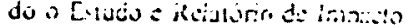

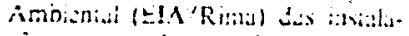

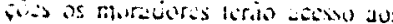

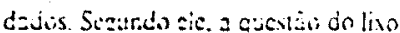

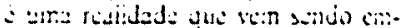

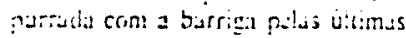
ennmistracoses a deval brot un

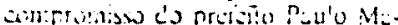

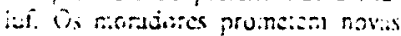

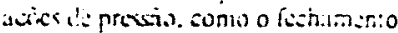

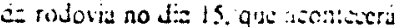
ca ziture do am 25 onde tra: o t:cro

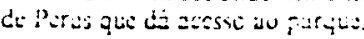




\section{Maluf quer incineradores de lixo em toda a cidade}

Até ofinal do ano, o preicito Paulo Maluf espera assinar o projeto de ins. talaça de incineradores de lixo na cidade. A aquisicào dos cquipsmétentos ainda está em processo de julgamento de uma concorrencia publica interna cional e na dependeneia de aprovaçào dos poderes competentes, como o aval de financiamento do Governo Federal. Maluf disse que quer ver os equipamentos funcionando antes de deixar a Prefeitura.

Cs incineradorcs, segundo o prefei. to. trarào economia ao municipio. porque hoje gasta-se muito com o transporte de lixo aos aterros. Esses equipamentos também nào poluem. acrescentou Maluf, e podem ser instalados mais proximo de onde se encontra o lixo. A idéia do prefeito é adotar incineradores tambem na usina de compostagem de São Mateus, cujo fechamento esta sendo reivindicado por moradores da Zona Leste.

Segundo Maluf. a desativacão da usina é impossivel. "Mas vamos pegar aquela instalaçào velha e colocar os incineradores. transformando o loca $\mathrm{cm}$ uma nova usina. como as que vi na França e na Alemanha. que mais parecem escritórios de tào bonitas $\mathrm{e}$ ao lado de residéncias, porque respeitam o meio ambiente e nào poluem."

$\mathrm{O}$ prefeito inspecionou ontem o aterro sanitário São Joào, no $\mathrm{km} 33$ da estrada de Sapopemba. Zona Leste. Atuaimente, o lixào recebe très mil toneladas/dia de detritos, quase mil toneladas/dia a mais do que sua capacidade. Instalado em 92, em area de $824 \mathrm{mil} \mathrm{m}^{2}$. o aterro foi projetado para funcionar por 11 anos, mas a sobrecarga de lixo reduziu sua vida útil para oito anos. O local recebe lixo da Zona Leste. Centro e região da avenida Ricardo Jafet. na Zona Sul.

"O aterro Sào Joào fíca lone de todo mundo. na divisa com Maua. mas nào podemos instalar atcros a 50 ou 80 quilometros de distancia. Te mos de nos preocupar com a relaçào custo-beneficio. Por isso. cueremos economizar dinheiro com os incineradores", explicou o prefeito. 


\section{Usina de incineração}

\section{de lixo causa protesto}

Aproximadamente 400 moradores de Sào Mateus, Zoña Leste, protesta. ram contra a instalaçào de uma usina de incineração de lixo ao lado do antico aterro sanilario no $\mathrm{km} 26$ da avenida Sapopemba - Esta area estava destinada, na administraçào anterior. à construção de casas populares. Agora, a Prefeitura quer colocar aqui uma usina" disse Marina Bernardo uma das coordenadoras da manifestaçào.

Segundo Marina, os moradores entrarào nos próximos dias com uma ação na Justiça contra a instalação da usina de incineracão. "O projeto de construcào nem tem relatório de impacto ambiental", acrescentou. Du rante o protesto, crianças plantaram arvores. Segundo os manifestantes, a área está sendo desmatada para construçào da usina.

Oensenheiro Bruno Cervone, direlor da Divisào de Compostagem do Departamento de Limpeza Urbana da Prefeitura, garantiu que nào have rá emissào de poluentes pela chamine da usina. "Nào haverá nenhum risco, pois será usada tecnologia modema, com filtros que controlam a poluição."

Segundo Cerrone, a usina de incineração é necessária porque não existem mais àreas para aterros sanita. rios. Ele explicou que a área da futura usina não está seni' desmatada, como afirmaram os moradores. "O que está acontecendo são obras de recuperaçào do antigo aterro sanitário ao ado." O aterro será transformado em área de lazer.

A usina será construida por um consórcio entre as empresas V'ega Sopave Martin e a francesa Compagnie Generale de Chauffe. O diretor da Divisão de Compostagem contou que o consorcio esta preparando relatono de impacto ambiental final. A construçào da usina será iniciada somente depois que o relatório for aprovado pelos órgãos competentes. As obras devem demorar 26 meses. A Prefeitura pagará as empresas por tonelada de lixo incinerada.

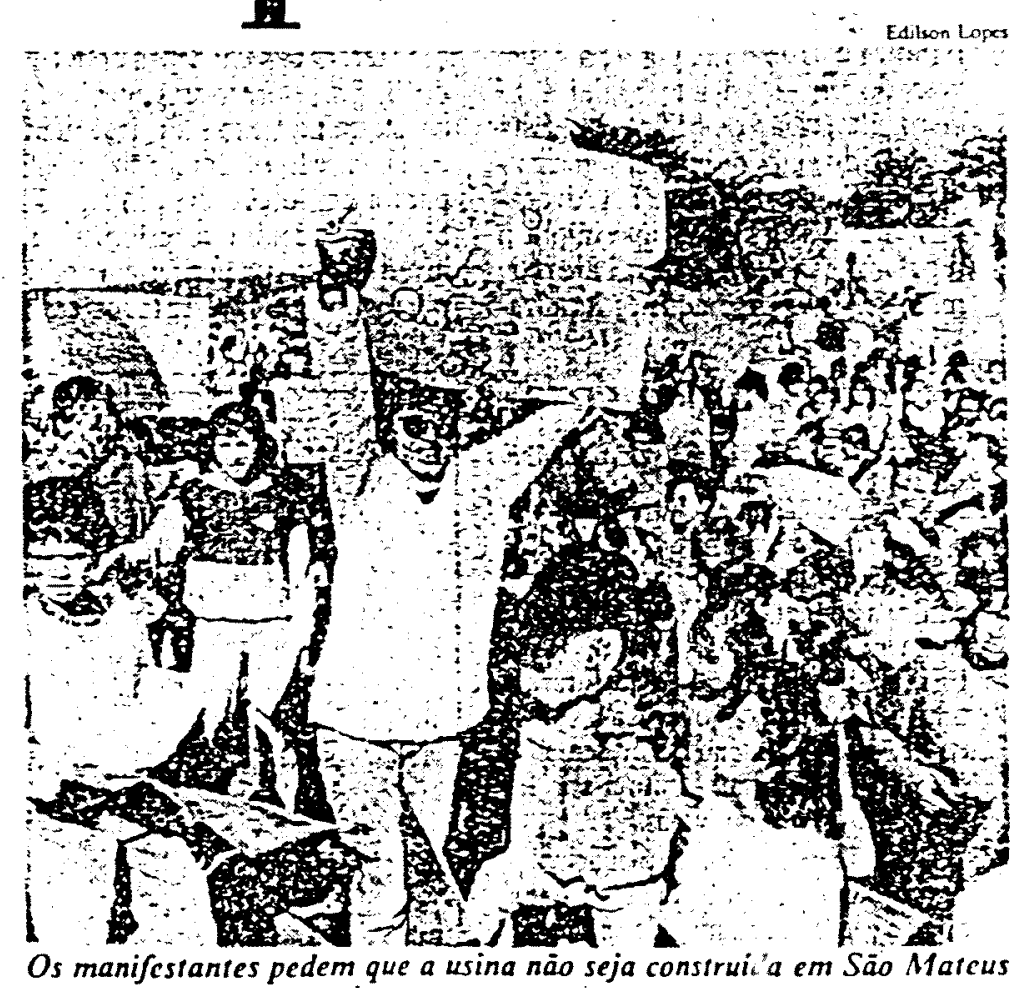




\section{O cartel do lixo na cidade}

\section{NIVALDO SANTANA}

A cidade de São Paulo produz $15 \mathrm{mil}$ toneladas de lixo por dia. Fonte de riqueza, o lixo não ver sendo tratado de maneira adequada. Restos de alimentos são misturados com plásticos, mctais, vidros c outros. Esses detritos, uma vez separados, podem - e devem - produzir dividendos que, se bem administrados, transformarão-se cm bencícios para a propria cidade.

Atualmente não é essa a trilha que vem sen. do seguida pela Prefcitura de São Paulo. $O$ prefeito Paulo Maluf vem fazendo do lixo um meio de favorecimento aus lobbies empresa. riais, deixando os interesses colctivos $\mathrm{cm}$ se. gundo plano. A coleta seletiva iniciada na gestiso da prefeita Luiza Erundina foi abandona$\mathrm{da}, \mathrm{e}$, agora, um grande e maléfico projeto pode transformar o problema do lixo $\mathrm{cm}$ uma ameaçadora investida contra a saúde e o meio ambiente: as usinas de incineraçào.

Importadas da Europa, com tccnologia ul. trapassada $e$ não aceita mais $\mathrm{cm}$ parte ajguma do mundo, clas trazem o terror e destruiçio para o ecossistema urbano equilibrado. Forma irracional de tratamento, a queima do lixo, assim como os aterros, nào destróm materiais quimicos e metais pesados, restando um residuo altamente tóxico, capaz ce provocar càncer em criancas e adultos.

O Parque Aninanguera, maior parque do municipio com 10 milhócs de metros quadrados - 10 vezes a dimensào do Parque Ibira. puera - está recebendo de forma ciandestina lixo cru, proveniente da usina Vila Leopoldjna. Esse lixo possivelmente ja contaminou o lençol de água da regiào, assim como o solo do parque. Centenas de animais silvestres que ha. bitam a área correm scrios riscos de desaparecimento, enquanto a flora vai gradativamente sendo afetada.

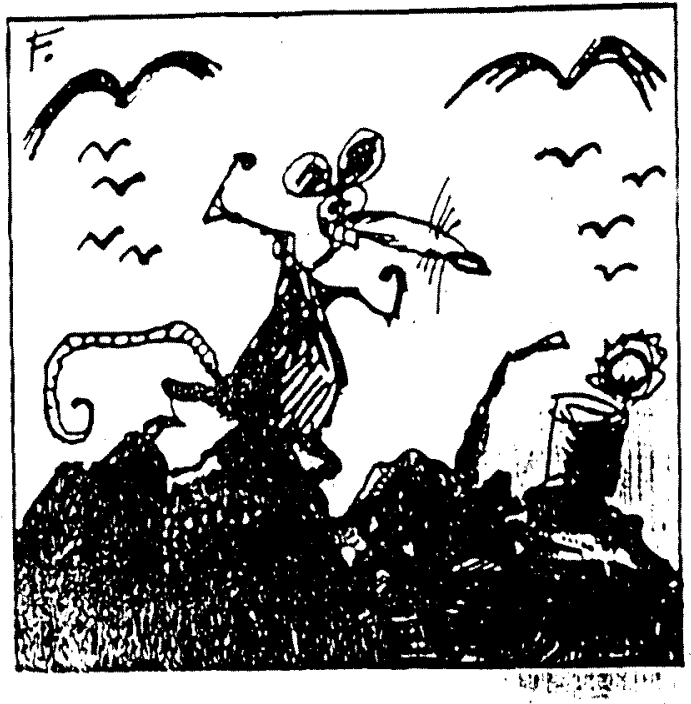

A água, recurso escasso $\mathrm{cm}$ uma metrópole como São Paulo, uma vez ameaçada, toma-se dirctamente una agressajo ao habitante de Perus, que ja sofre tij dez anos com as consequencias do aterro Bandeirantes, foco de doenças e contaminaçōes.

O prefeito penaiiza ainda mais a popidaçào com o projeto de instalaçấo de uma usina de compostagem dentro do Parque Anhanguera, juntamente com outras instalaçóes já definidas cm Santo Amaro c São Mateus. Como se nào bastasse isso, fornece criminosas garantias fi. nanceiras is empresas coletora de lixo, num gesto ir:isponsavel, financiando emprestimos com dinheiro publico em favor dos empresarios lobistas.

A populacão de Perus exige imediatamente 3 inicrnupção do processo $\mathrm{cm}$ andamento da instalação da usina de incineraçio, assim co. mo uma politica scria $\mathrm{c}$ honesta para com um problema do seculo XX e XXI, o lixo.

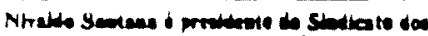

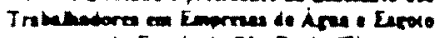
do Eardo do Sto Pade (Sincerven) 


\section{O lixo e a demagogia}

\section{JOSE NITTAREIIII}

$\mathbf{E}$ $m$ busca de notoriedade, o sindicalista Nivaldo Santana aveniura-se pelo ierreno do lixo. Seu arugo publicado no DIARIO POPULAR, na ediça de 29 de julho. e um primor de desiniormacào de oportunismo politico, sobre um problema que de fato e grave e merece uma abordagem seria.

A Grande Sào Paulo produz diariamente $17 \mathrm{mil}$ toneladas de lixo, das quais 13 mil correspondem a cidade de Sào Paulo le nào 15 mil. numero "chutado" pelo articulista). Quando se leva $\mathrm{em}$ conta que este ano serào necessarios 18 quilometros quadrados para aterrar o lixo produzido pela regiào metropolitana. $c$ que as projecóes indicam que em 2010 a producão de lixo diaria sera de $24 \mathrm{mil}$ toneladas, venfica-se que preciso algo mais que demagogia para o equacionamento do problema.

A colela seleluva de lixo, permitindo a reciclagem -industrial de plásticos, papel e papelào, vidros e metais, e uma soluçào cantada em prosa e verso como a ideal. so que mesmo nos paises mais desenvolvidos educacional e tecnologicamente esta modalidade ate hoje nào ulırapassou $10 \%$ do lolal. O nó da questào ć a viabilidade económica: no modelo implantado $\mathrm{em}$ Sảo Paulo durante a gesiáo passada, o lixo era separa. do pela populaçào, misturado depois no caminhào e novamente separado manualmente em uma esteira; o resultado e que o custo por tonelada saia por USS 400 para a Prefellura e era vendido por USS 50 para as indústrias interessadas. Mas com novos estudos viabilizamos uma coleta seleciva mais logica e nos proximos 60 dias mats 200 conteineres serão instalados gratuitamente pela cidade.

Outro mito co tal do "cancl do lixo". Quando a expreicita Luiza Erundina se dispos a "descartclizar" este serviço, entregou setores inieiros a empresas que nào unham caputal, mào-de-obra especializada e conhecimento tecnico. O resultado foi o quase colap. so da colcta. Basta dizer que em 93, primeiro ano da administracào do preielio Paulo Maluf, reliraram-se diariamente das ruas de Sào Paulo 3.3 toneladas de lixo a mais do que na adminisıraça anterior. Foram limpos 1.2 milhào de metros de galerias, 640 mil metros de bocas-de-lobo e I milhào de metros de corregos, de onde se reuraram 950 mil metros cubicos de lixo. Por sua relaça direta com a saude da popula. çào, a limpeza pública e a coleta do lixo nào podem, a nào ser irresponsavcimente. ser objeto de expenmentaçòes para atender ao "politicamente correto".

Alem dos mitos. existem as mentiras. Diz Nivaldo Santana que o Parque Anhanguera. na zona Oeste de Sào Paulo, esta reccbendo "clandesunamentc" lixo cru da usina da Vila Leopoldina e aue este lixo "possiveimente" já contaminou o lençol de agua $c$ o solo do parque.

$A$ verdade: em Vila Leopoldina, 500 das 1.000 tone. ladas diarias sjo transiormadas con composto organico. Entre maso e novembro a produçjo $c$ vendida para agncultores que utilizam o composto como adubo. Entre novembro e malo. é fetta a eslocagem. Para evitar problemas aos moradores de Vila Lcopoldina. bairro munto populoso. a Preicitura decidiu iransferir o composio processado ali para uma area dentro do Parque Anhanguera. Trata-se, no entanto, de uma clareira onde nào estào plantados cucaliptos, bem longe da area frequentada pelo publico. Nào é novidade essa estocagem. Outras administraçóes já fizeram 15so. M2s para urar uma "casquinha" da gestão Maluf vale tudo.

A perola final fica por conta das usinas de incinera. cào. O municipio dispóe hoje de duas usinas, na Ponte Pequena e Vergueiro. onde so se incinera lixo hospita. lar. A Prefeitura val construir outras duas usioas de incineraça com os equipamentos mais modernos, $\mathrm{cm}$ Santo Amaro e Sapopemba. con canacidade prevista de 2.500 toneladas por dia. Quanto ao absurdo de que a tecnologia e "ulirapassada" e espalhou na Europa "ierror e destruçào", basta dizer que em Paris uma delas pode ser avistada no alto da torre Eifel, em pleno perimetro urbano da cidade. $s e m$ que jamais qualquer probiema tenha sido constatado. Nos Esta. dos Unidos. Japào. Suiça, Alemanha etc., a solução adotada para tratar o lixo e por meio de incincraçào. com recuperaçajo de vapor ou energa elétrica.

Em resumo, a questáo do lixo e complexa. Passa pela conscienuzaçào da populaçào e dos empresarios. Requer tecnologla e pesquisa. No curto prazo, todos os meios, ainda que nào ideais - aterros. incineraçào. compostagem - devem ser utilizados. A longo prazo, se os politicamente corretos nào atrapalharem, a sociedade contribuira para desperdiçar menose aproveitar mais os residuos que ela propria produz.

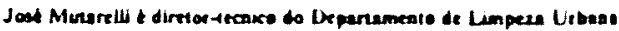




\section{Secretário promete resolver problema do lixo com usimas}

As 13 mil toneladas de lixo produzidas diariamente na Capital deixarao de ser problema no final da admins. traçao do pretcito Paulo Maluf. A promessa é do secreario municipal do Verde e Meio Ambiente. Werner Zulauf. que prometeu substutur os indesejareis hixóes por ires usinas de in. cincraciso e compostagem. yue come. carào a ser construidas anda este ano. O lixo. segundo ele. passira a ser uiil para a sociedade na forma de in. sumo para a agricultura e energia. o biogás.

O secretáio apresentou as diretri. zes do Plano Diretor de Residuos So. lidos do Municipio aos técnicos da Secretarla Estadual do Meio Ambiente e garantiu que a implantaça das tres usinas - cm Santo Amaro. Sapopemba e na regiào do parque da Anhangucra - sera a soluça para o probiema do lixo na cidade. Lulauf disse que as obras das uniclades de Sapopemba e Santo Amaro já foram licitadas. "Os estudos de impacto ambiental estão em processo final de elaboraçào". adiantou. "Cada usina custara entre USS 150 milhões e USS 170 milhòcs, o invesumento sera bancado pela inicialiva privada." Pelo contrato. as empresas poderào explorar as usinas por 20 anos. "D. desse periodo. as usinas passam ; a Prefeitura". Jembrou Zulauf. 


\section{Zona Leste recusa combustão de lixo}

SANTO ANDRE - Moradores da Luna Leste da Capital e de Santo Andre estio se mobilizando para $\mathrm{im}$. pedir que o prefoto Paulo Malufins. ate. cm Sio Matcus usinas incinera. doras de livo. Na scmana passada 0 secretario do Partido Verde. Werner Zulauf. estese na regiáo c conversou com a populasio. mas a maıria náo aprovou a obra por considerar a usina um "foco poluider". scgunos anunciou oniem Jose Contreras. stcretario do Morumento de Defesa es Vida (MDW). Ele disse que um reis. torio da EP'A (Environmental Pre. iection Aeencrl. de Washingle:

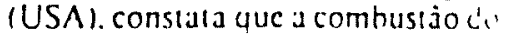
liso produz as dinxinas. que in cau sadoris do cancer. promeipalm:n: nos serus. c alteracoco geneticas. co. tno atrofia do orcio scxual. nos nomens. Alem disso. Contreras cits au: a regrio fa cetia aletada com o Polo Petroquimico de Capuaval e a usina de compostasem de Aricanduva. no Parque do Cirmo. 


\section{Protesto contra usinas despeja lixo na Câmara}

Uma grande quantidade de matc. rial em decomposicao. cmediaeens. papeis c garralas usadas foi desceinda cm frente a Cimara Municioal de Sào Paulo. em protesto contra o projeto da l'refeitura que preve a insialacio de tres usinas de incmeracio de lixo na periferia da Capial $A$ manilestaçào partiu do Centro de Convisenca Cultural de Piriluba c de ourras organizacóes nào governamentas. que lambem divulgaram manifesio alertando os vercadores sobre os custos ecologicos e financeiros das obras.

O principal alio do prolesio e a ins. alaço da usma de incincracio de li. xo no Aicro Banderantes. nis Zond Oeste - unico dos tres prolecos que ainda najo foi licitado - uue nica no parque Anhaneucra. atuamente a maior reserva florestal do inumeipo. quase 10 vezes maror que o parque do lbirapuera. As outras duas usinas. uma cm Sāo Mateus. na Zona Leste. a outra cm Santo Amaro. Zuna Sul.ji
Iveram suas obras mondas com os servicos de icranicnacem.

O presidenie do ceniro de convi. iencha. Edson Dommencs. arsumen. ha que a adocio desse melode de imer. neraço de lixo cru provocid a libera. cio de uma substancia chamada dice. sina. altamente canceriecna.

\section{CARTEL.}

Orcado cm R\$ 450 milhoes. a cxecucào do projeto foi possibilitada nor uma licitacio internacional $\mathrm{cm}$ que so as grandes "empreitciras do lixo". como a itahana De Bariolomets. a fran. cesa Martan e as hrasticaras icea c CGC. Meram chances de salm verion. sis.

Os manfestantes critcam untem os icrmos do proicto. Que colocam a Prefcitura como avalisha das cmnres.5 que reahizam as obras. "So uma dessas empresas pedir concordata. of cofres municinars e que vio arcar com ns custos". alirma Dommeues. 


\section{Moradores contra incincradora de Maluf}

SANTO ANDRE - O prefeilo paulisiano Paulo Maluf podera cn. comrar resisicnca dos moradores de Santo Andre c Maua para a implan. taçào de uma usina incineradora de lixo $\mathrm{cm}$ Sio Mateus. Zona Leste da Carpital, divisa com os dois munici. pios do $A B C$. Jusc Contreras. presidente do MDV (Movimento de De. fesa da Vida), que $\mathrm{cm}$ participado das reunióes com a populacjo. exibiu onicm documiento da EPA (Environmental Protecion Agency). de Washungion (USA) onde constata que a combusiáo provocada com a yucima do loxo produz as dioxmas. causidoras de cincer. prancipalmente nos scios. No homem. segundo o relatono. a dioxina provoca alteracóes genclicas com a atrofia dos ór. gàos sexuais. O Mormento de Defe. sa da Vida apresenia como proposta a coleta seferiva. o yue possibilita o reaproveilanento da mator parte do lixo. "Lissa nossa proposia c recusada porque a colela é uma mina de ouro para as cmpresas contraladas para a culcta du lixo". esciarcec Conircras. accntuando que so na Capital sào recolhidas por dia 12.500 toncla. das de lixo e que a Vega-Sopave. res. ponsivel pela coleta. "i hoje a quar. ia maior cimpresa do mundo nesse ramo de atiridade". Caso Malul consiga impiantar scu projeto. a usina prejudicaria os moridores do Par. que Novo Oratorio. Capuara e Ana Sofia (Santo Andre). Jardm Silvia Maria. Zaira e Sonia Maria (Maus). alcm da propria Zona Lesic. 


\section{Prolesto marca} audiència sobre usina de liato

Moradures da Zona l.csle prolesta. ram. durance audicion publica bis Camara Municipal Contra u projecos do preicito Paulo Maluf de insialar uma usma de processianemo de resi. duos solidos domiliates incincracá de lixo cm Sapopembat Aposados por vereadores e deputados csiaduar c federais do P'T os mamfestantes anumbaram que hio contrar com açio na Justace para minedat a consuracion Ja usma.

Na audiencas. onde form deball.
Jus o Listudo c o Rchalono de Impuc.

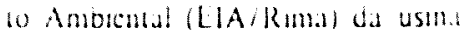
de lixo. as cxplacacoes dos lecnicos najo convenceram os moradores de que eles nào correm rasco de contrair docncis. O audiono com capacidade para 120 pessoas ficou totadu. Os milmiresiantes temem quic as cumssócs 10 . xicas dos incineradores causem cancer. prejudiquem o desenvolumento fisico e mental de crancias e compro. metam o sistema imunológico das pessoas. Os icenicos descartam esses riscos.

Segundo o engenherio sambarisin

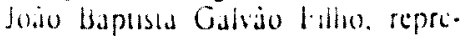
senianie da empresa de consultori. Brocna responsavel peio llA/Rima
Wh usma de Sapopemba u risco de se contrair cancer por doxinal de um $m$. cincravor e de um caso cm 10 milhocs. "Para quem fuma apenas uni cigarro por dia o risco e de um caso $\mathrm{cm}$ um miliso". comparou. O encontro fai presidido pelo secreiario municipal wo Verue c Mejo smownte. Werner Zulaui. que na administracio do $\mathrm{cx}$ precicio Jinio Quadros liderou un movintmo que impediu a mislalaço de usinas semeihanies. "O problema i que nuquela epoca a administracion municipal quena construir usina $\mathrm{sem}$ os estuco de impacio amuiental". jusblicun lloje ele defende a instaluscio das usmas porque a cidade njo $1 \mathrm{~cm}$ misis onde iazcr aterros sanmarios. 


\section{- Incincrador}

O vercador Italo Cardoso (PT) esta organzando a populacào de Interliggos para resisur at proposta do precicito Paulo Ma. luf de instalar um incinerador proximo ao autodromo. a beira da represa Guarapiranga. Alem de destacar que a medida trara scrios prejuzos a saude da populaçào. o petista tambem acha estrantio o fato de os tres novos incincradores - cm Interlagos. Perus e Säo Mateus - serem pagos por cmpresas particulares. que. atraves de consorcio. terão exclusividade na cxploraçáo do lixo por 20 anos. "Sera um serviço publico monopolizado". disse. 


\section{Moradores protestam contra lixo}

and

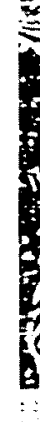
p

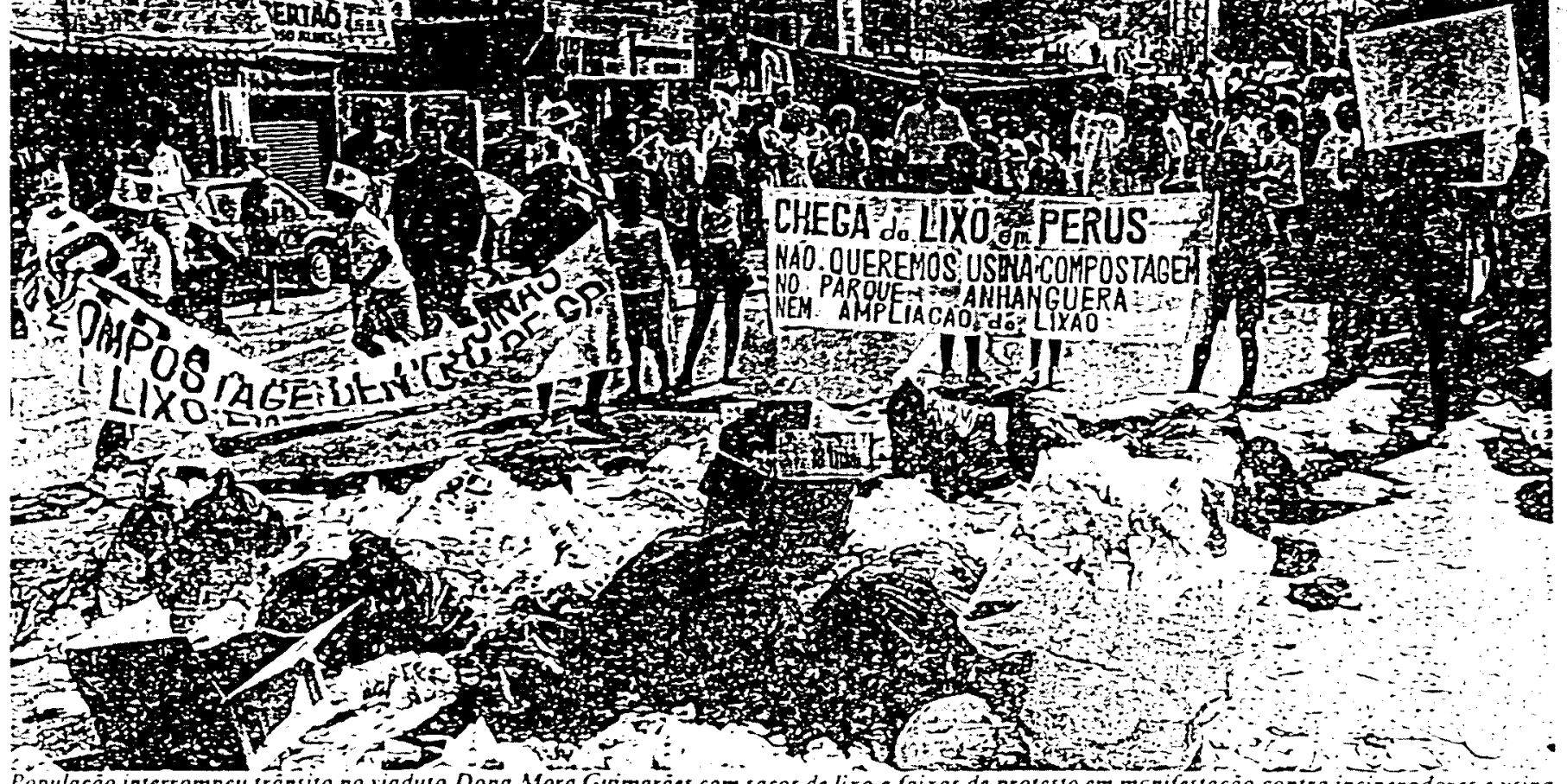

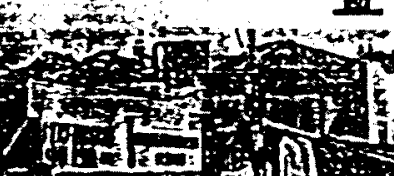
tis i. CHEGA dULXONOTERUS

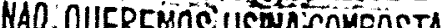
HWUERA 1.M. AMPLIACAOFd o: LIXAO
Moradores de Perus, Zona Oeste, realizaram uma manifestaça contra - projeto da Prefeitura de instalar no bairro incineradores e uma usina de compostagem de lixo e estender por mais 15 anos a atividade do aterro sanitario que funciona no local. Os manifestantes interromperam o tiansito no viadulo Dona Mrara Guima iesto depois de informados que 0 se cretirio municipal do Verde -1 eio Ambiente Werter Zulaf, aue deve Ambicnle. Wemer Zulaur, que devede Perus acompantando o projeto de Perus acompanhando a projelo Bairro

Os moradores literanam a pista de pois que o tecnico en comunicagio da CET Jose Oliveira Futho convenceu os manifestantes a escolher uma comissäo para ser recebida pelo serre-
tátio das Administracoes Regionais, tátio das Adminstraçoes Regionals. Francisco Nielo Marnin, e por representantes da Secretaria do Verde e Meio Ambiente. Eles conseguiram marcar uma audiencia com Zuau para dia 8

Segundo Paulo Rodrigues. um dos lideres do movimento contra o lixáo, a manutença do aterro sanitário $\mathrm{e} \mathrm{a}$ instalacao da usina e incineradores no local contrariam leis staduais e fode ais de proteça a a meio ambiente colocam em risco o parque Anhanguera, reseria de Mala Altantica on de os equipamentos seriam instala dos. As autonidades realizam au. diências publicas sobre a questão para simular uma consulta democrática. mas na realidade já escolheram o lo cal e até realizaram as licitacoes par concretizar o projeto", declarou.

Para os moradores, a instalacào dos novos equipamentos vai piorar a qualidade de vida da comunidade aumentar a poluiça no bairro. "A umaça dos incincradores $c$ loxica pode causar doencas, e a Préeitura Aambem vai trazer para o parque Anhangueta as cinzas de oultos dois incineradores, que serão enterradas en valas e pouem conprometer o len col freático". avaliou Preciosa da Sil a, da comissão de moradores.

A assessoria de imprensa da Secre aria do Verde informou que os lerre nos onde seráo instalados os equipa menlos năo ficam no parque Anhad guera. mas em imores pariculares que estào em processo de desapro priação e não terão de solrer desmá mento para serem utilizados. 


\section{Prefeitura mantém aterro e usina de lixo em Perus}

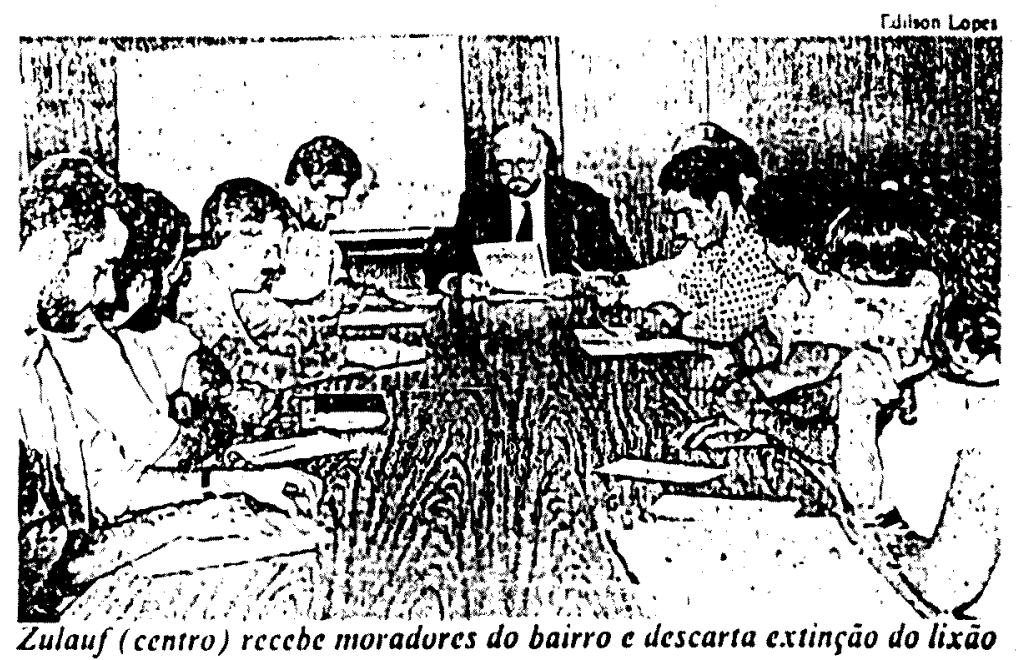

Os moradores de lerus. Zona Oes. 1c. Ieräo de se conformar c conviver com o ancro samtarto $c$ usinas $d e$ compostapem c incincraçio de lixo yue al Prelcilura pretende instalar no local. Uma comissjo de setc moradores for recebida onicm nelo secretáno municipal do Verde c Meio Ambiente. Werner Zulaul, que expos os critcrios para a cscolha do local e descartou a possibilidade de mudancas.

Os moradores foram reivindicar o cumprimento de tha promessa de campanha do preficio Paulo Maluf. "Elc falou que iria desalivar o alerro sanitario de Perus calc assinamos um documento com o cx-sectetario Hygino Bapuston que preva a exincia do lixáo para este mes", salientou Paulo Rodrigues, membro da comissão.

Os moradores temen que. com a instalacio das usimas c extcnsio do aterro, aumente a polucicio do ar. da agua $c$ o desmatamenio no parque Anhanguera, uma reserval de Mata Allimeca au lado do alerro. "Apesar da alimmaço da secretaria de que os terronos para as usmas nio lazem parte do parque, a divisajo cutre cles $\dot{c}$ tecnica c juridica, pois, na pratica, os terrenos são vizinhos", frisou Rodrigues. Zulauf disse que o problema da destinaçio do lixo c a primcipal ques. tjo ambiental da cidade. "Existem poucas áreas disponiveis $c$ a Prefeitura optou por trés pólos para a destinaço final do lixo. cm Santo Amaro, Súo Mi lcus e Perus", cxplicou.

Zulauf defendeu a coleta seletiva de lixo para reciclagem, mas destacou que $c$ um processo caro, que exige subsidios $\mathrm{e}$ so atimgiria uma pequena parte das nove mil toncladas de lixo produzidas diariamente na Capilal. "Minha sugestjo c oricntar a populaciu a separar o lixo orgánico do inorginco faciliando a colcla c a scparaçao para a reciclagem", ressaltou. Outral sugestuo de Zulauf foi a organizaciio de comissócs de moradores para montorar a atividade das usinas $\mathrm{c}$ garanir que os padróes de poluiço não ultrapassem os nivers accilivess. "Essc pessoal seria Ircimado ma secretaria para ter condiços de exigir informacóes corretas dos icenicos". complelou 


\section{Adiada votação de relatório} sobre incineradores de lixo

Foi adiada para 6 de janciro a vola. ciro do Estudo e do Relatorio de Im. pacto Ambicnal (E/A/Rima) dos incincradores para tratamento de lixo que a Prefeitura pretende instalar $\mathrm{cm}$ Sapopemba c Santo Amaro. O adiamento foi decidido por 14 votos conlra oito dos menibros do Consclho Municipal de Meio Ambiente e Desenvolvimento Sustentavel (Cades). A reuniào demorou mais de cinco horas c uin grupo de moridores dos bairros prolestou com faixas c cartazes.

As pessoas contrairias ao projeto afirmam que os incincradores, que deverio custar US\$ 350 milhòcs, irão liberar dioxina (substancia cancerigena que pode provocar problemas no aparcho reprodutor $c$ no sistema immonologico). A cimbara kenica do Cades lez amalise preliminar e sugeriu a aprovaçio com ressalvals.

Sepando Marijame Lisboa, coorde. nudora regional do Grecnpeace, estudos mundiais garantem que os incineradores sio a principal fonte de contaminaçio atmosferica por dioxina. "E um metodo que nào se usa mais nos paises descnvolvidos, por isso as fibricas desses equipamentos estio vindo para os paises do Terceiro Mundo". disic. Ela explicou yuc a dioxima persiste no orginismo entre 20 c 40 anos $L$, alem do cancer, provoca esterilidade, interrupcio de gravidez c ma formacio congenila nos felos. O secretinio municipal do Verde c

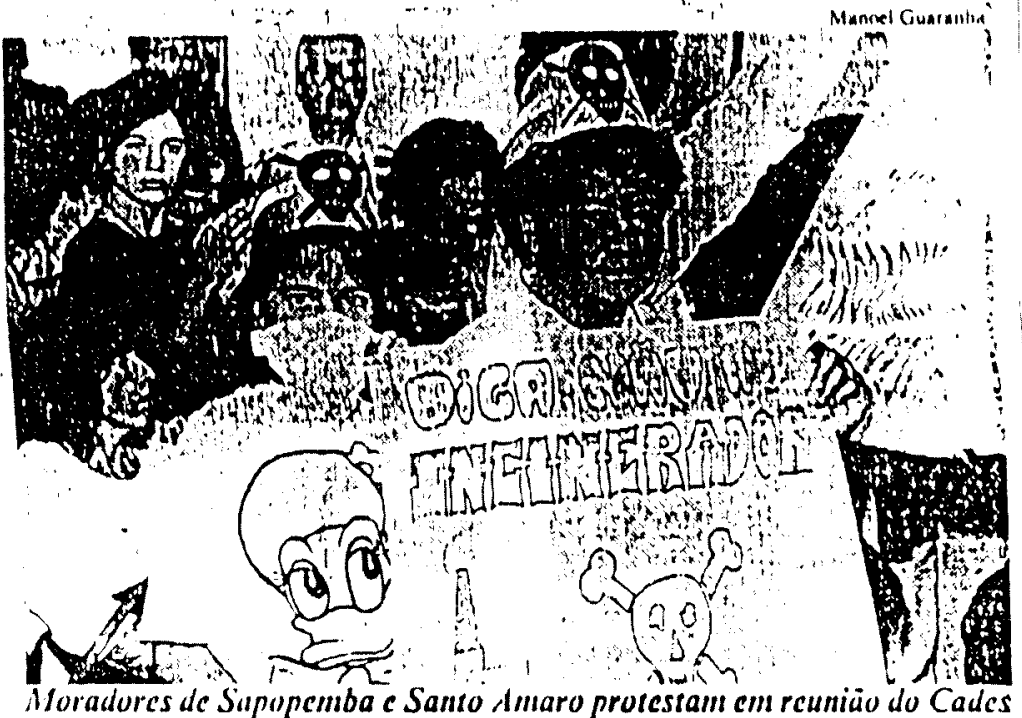

Mcio Ambiente. Werner Zulauf, presidenic do Cades, acredila que os incineradores existentes ma cidade colocain als pessuals a uma exposicjo maior do que os que sera instalados.

Um argumento que pesou para que a voliçijo fosse adiada foi o questiomaram de que a instalaço afctará municipios vizinhos $\mathrm{c}$, assim, o poder de decisio seria do Consema. órgio estadual. Os conscheiros decidiram adiar a votaçio para cstudar melhor o assumto.

\section{MOBLLIZAÇÃO}

Os represcntantes dos movimentos populares de Sapopemba c Santo Amaro estio mobilizatos para impedir a consiruçio dos incincradores. $A$ proposta da Prereitura é instalar uni terceiro $\mathrm{cm}$ Perus, Zona Ocsic, parí dar conla das 12 mil concladiss de lixo produzidas diariamente na cidade. As lideranças consideraram positivo a adiamento.

O cmprestimo de USS 500 milhòcs que a Prefcitura pediu a organismos internacionais para a consuruçio das usinas e dos incincradores cstit amcil ciddo. O Banco Central neguu all Ba:" nespa a autorizacilo para imermediar o cmpréstimo na scmana passada. Um dos motivos foi que a laxa de livo cobrada no IPTU foi dada como gilruntia do compréstimo duramte 20 anos. 


\section{Protesto contra incineradores}

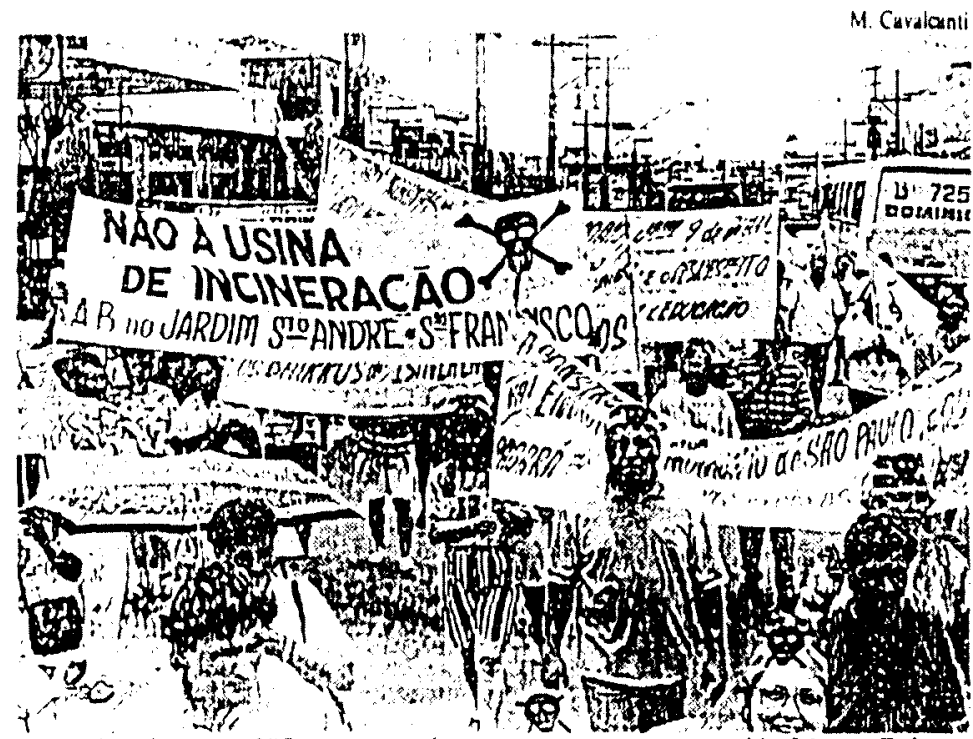

Aproximndamente 100 pessoas sairam $\mathrm{cm}$ passcata na avenida Matco $\mathrm{Bci}, \mathrm{cm}$ dirç̧ào à praça Felisberto Fernandes da Silva, conhecida como largo de São Matcus, Zona Lcste, para protestar contra o projeto da Prefcitura de impiantaçào de três incincradores de lixo na Capital. Segurando faixas c cartazcs, os manifestantes, que tinham apoio do Clube dos Lojistas, conseguiram a adesajo de mais comerciantes, que fediaram as portas para acompanhá-los. $O$ tránsito ficou complicado na regiajo. São Matcus é un dos bairros onde está prevista a implantação de incincrador. Os outros dois sảo Santo Amaro c P'crus 


\section{Cades aprova instalação de incineradores de lixo}

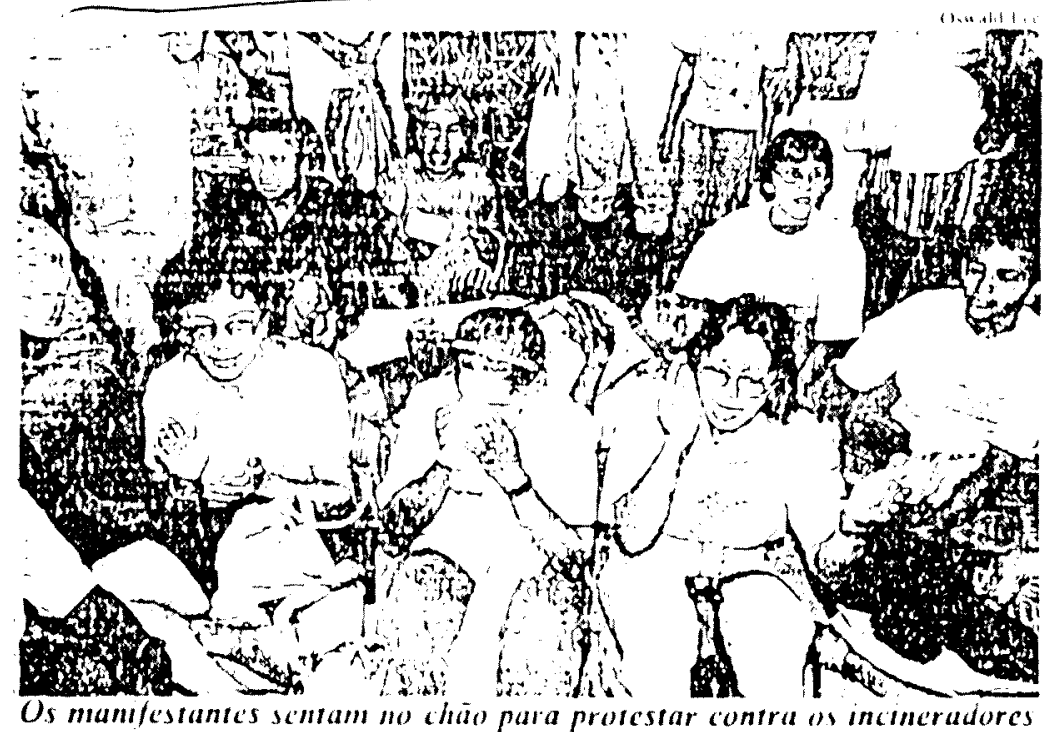

O Consciho Municupal de Meno Ambiente e Desenvolvimento SustenLavel (Cades) aprovou o Estudo e o Relatorio de Impacto Ambiental IIIA-Rimal que concede a licencis ambental preva para mplantacio dos memeradores de lino de Santo Amaro. Lona Sul e Sanopemba Lona Leste. A reumio. Hi Sectetama do

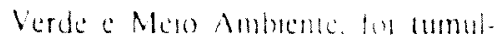
Itada por mantostantes

- Junto com o I IA R Rma hat aprova. - do ume parcer chaborabe nola Camaga Tecnea presidida petu jurnalista e ambientalista Randolpho Lobato. que exige que os incmeratores obedeCam para cleato de lancimento de po. luentes na atmosfera o padra mave. mo de emissio de 0.14 ny $/ \mathrm{Nm} 3114$ sentesmos de nalloeramas por nor. mal metro cubicol" "lsse controle Sfasta o perieg de as pessonas ane mo. 5um proxmas combrarem cancer" Earanmo osecretano do berde e Meso Ambente Wermer Lubat que prot. Thu a remono.
Dos 29 conscheiros presentes. 25 volaram a favor da construcia lias usmas. tres se absweram e Ama Ma. raj Publero volou contra. Ha alegou que as questoes disculdiats nas andienche publicas nato foram levidat em consideracio na conkccio do LIARuma Mas Zulaufafirmou gue iodas as audienches publicas foram grab. dise pesterormente for anrovato um relatono. O secretarne explacou une a concessio definurva para implanalcio dessas usinas somente serid dadi quando as empresas responsavers pelos emprecnumentos apresentarem o detallamento do projeto.

No final da reunijo do Cades integrantes do movimento popular contrario a implantacio das usinas sentaram na pora da Secretara do Verde: Meio Ambiente para protestar conira os conselherros que aprovaram o ElA-Rima. A mantestacia durou 40 minutos e dificulton a salda do predo. na avenida Pauhista. 2.073. dos incerantes do movimento a favor da mplantacio dos momeradores 


\section{Manifestação critica usina de lixo na região de Perus}

Lideres ecologicos e politicos comemoraram o amiversario de Sio Paulo com um prolesto comera a inslalacio pela Prefeslura de um incincrador de lixa e uma usina de compostagem nal regiào de lerus. Com shows musicalis c discursos. as allvistas procuraram demonstrar as pessoas que estabam no parque Anhanguera que a instalacajo das duas unidades no local vao provocar varios problemas de saude. entre eles cancer.

Paulo Rodrigues, do Movimento contrat a Instalacio de Incineradores na Cidade de Silo Paulo. alirmou que os equapamentos que a Prefellura pretende usar sio ultrapassados e por isso nà garantem a preservacia do mero ambiente. Segunio ele. o siste. ma de fillragem nio impede que sejam lancados ao ar compostos que se orignam da quema do lixo, como dioxinas e furanos, entre outros.

Alem de causar cancer. pesquisas recentes demostraram que aqueler compostos afeam o sistema reprodu. two. provocando abortos. ma formacào de fetos. esterilidade e atrofia dos orgào sexuais. Tambem podem provocar retardamento mental c afecar o sisicma imunologico. Pullo Rodrigues explicou que nào so a populaça de Perus sera alinguda pelo problema: "Todos os barros c cidades provimos, inclussie o Sul de Minas Gerans. estarào comprometidos". garantiu.

Como alguns desses compostos san bioacumulainvos - acumulam-se nos seres vivos atraves da cadela alimenlar - quein comer carne nu beber leile de anmais que se alimentarem com

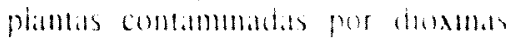
aumenta a cargat dessa substancla em scu organismo. licando mals sujerto a adquirir um cancer.

Os organizadores do prolesio crill. caram a postura do secretano municipal do Verde e Mcio Ambiente. Werner Zulauf. de defender a mstalaçio dessas usimas na Capital. "No passado. ele (Zulaun falava cobras c lagarlos dessas usmas e nao explicou ate agcra o porque de ter mudado de opiniào". afirmou Paulo Rodrigues.

Os ecologistas acusam a Prefeitura de querer dar uma soluço maglea para o lixo e defendem a adoço de uma politica de reciclasem com a participacio de municipios proximos. Reconhecem. porem. as dificuldades para implanlacjo dessa altermaluva. uma vez que a populacio ainda nào se deu conta da dimensajo do probiemat. Onlem, por exemplo, pouco mais de 40 pessoas. incluidos os organizadores. participaram do protesto. que so chamou um pouco mais a alencào do pu. blico durante a apresentacio do canfor Ze Giraldo. 


\section{Moradores entram na Justing}

\section{contra}

Noventa e seis moradores dos bair ros de Sào Mateus. Santo Amaro e Pl. rituba ingressaram na S"Vara da Fa zenda Pública da Capital con uma aça popular, com pedido de liminar. conua a instalacajo de duas usinas de incineraça de lixo em áreas de Santo Amaro e Sapopenuba. Os moradores querem que a Justiça declare nulo os atos de licitaça, suspendendo incdiatamente o processo de licenciamento aulorizado pela Prefeitura. Como ar gumento apontam 53 irregularidades cumcridas desde a fase de licitaçăo

Un abalxo-assinado com $22 \mathrm{mil}$ as sinaturas de moradores atingidos dire lamence pela instalagajo das usinas acompantia a açăo. Um grupo de inoradures realizou passeata desde a ave nida Paulista até o prédio onde funciona o Fórum da Fazenda Pública, na rud Joaquim Eugènio de Limo, para chamar a atcnção da populaça. Con faixas c callazes eles procuravam acentuar os prejulzos à saute que a insialaçăo dos incineradores pode pro. vocar. Está comprovado em paises : da Europa que os incincradores. atra-

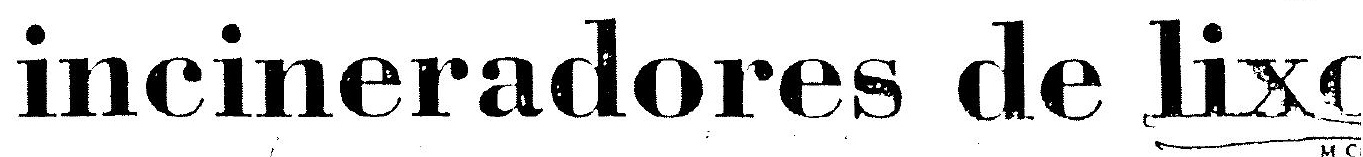

vés da liberição de dioximas. causam problemas de saude, como cancer de pele. e não comerdámos com o desti. no que está sendo dido ao nosso di. nheiro, sem que sejumos consullados". disse o lícnico de consarugajo civil Sergio Panlo Nogerino.

\section{FAIIIS}

Segundo o adrogado Altónio Fer. nando Pintero Pedro, as irregularida. des väo desdi a liciaça, ao eshabcle cer uma forma que possibilita a parnci. paçăo suntond: de enpresas de grande potte no processo. passam pcla ausencta de licenchancmo estadual e vão ate a próprla construça das usinas. "A Prefciara tenton mascarar o cmprecn. dimente licando alrás dos consorcios que ganharan a conconèncla, incumbindo as concessionaras da obtençio da licença ambichtal". afirmou.

\section{PRO(T)SSO}

A Prefouma inciou o processu de licitaço publica para a conslaticato dis duas usinas em novembio de 191). Em abril de 9 to processo estata cm

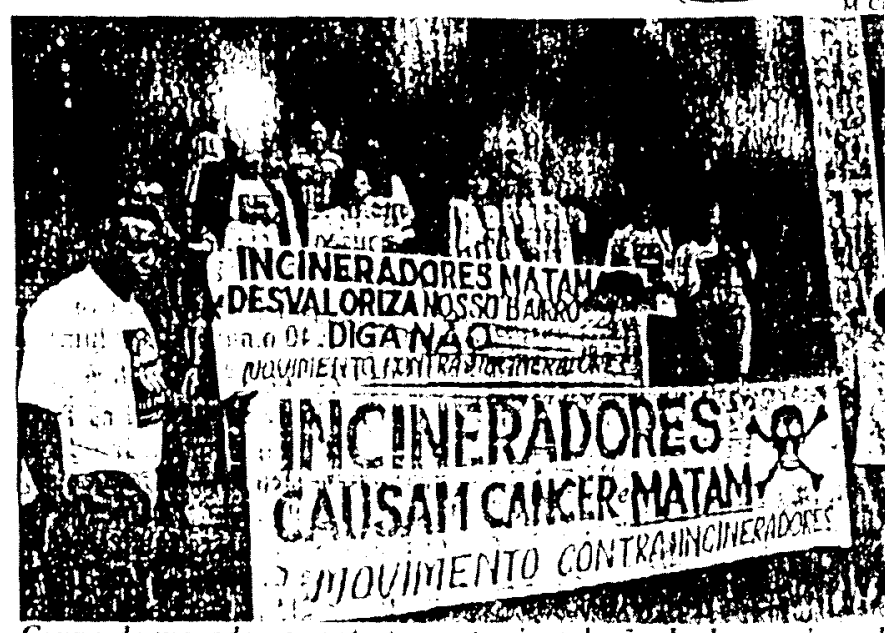
Grupo de moradores protesta contra instalafäa de duas usinas d clufdo, tendo como vencedores da concorrència os conobrous litescoe De Balolomer, parat a comstraça da usina de Sintu Amaro, t Vega-Supa. ve, CGC e Marmon para a usaria de Sa. pupemba. Segundo os anores la açán aproximadamene US\$ 600 mollowes.
Un grupo de moradores seg! pois até a Delegacia de Infraçōc la o Mcio Ambiente, do Decon regiserou un bulctim de veor contra um incinerador instal: avenida Doutor Ricardo Jafer. cehe resfluos $5 \mathrm{~cm}$ a clissifted clementos populat. oprocesso lichathiso carblve 


\section{São Maleus prolestan}

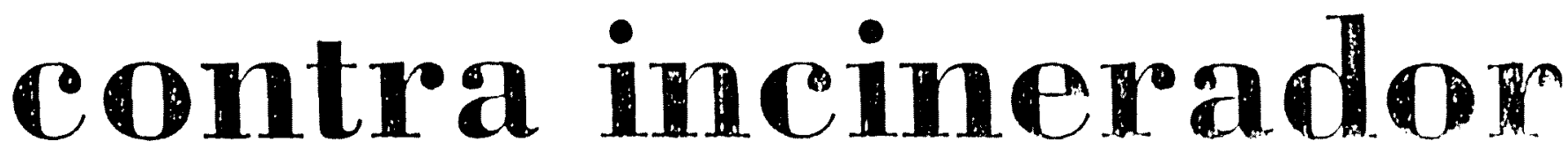

Moradures da Zona leste fizeram onton uma cummodia de protesto con. lia a umplantaçào de un incineradot do liro em Sio Alareus. A canumbadu, que Lamben comemonava o Domingo de Ramos foi organzada pela igreja Ro. dolfo Pursni e pelo Mormento Combra a linsalişa de llimas de lncincração de Lixo na Cidade de Sáo Palulo. c reuniu mais de duas niil pessoas. Elas sairam da igrcja e scguiran por quase um qui. lomeln pela avenida Rodolfo Piran ate

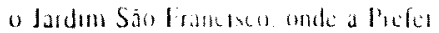
lura pretende dosde a latal de 1993 imsular o moneratar

Segundo or promentanes de dmon

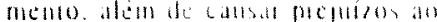
melu ambiente a progeto da Preforta

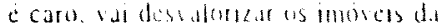

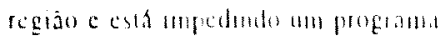

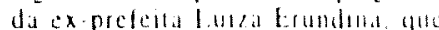
desumara a area a conshuçă de no radus poptahates atraces thestema de mulnocs
Mais de conco mil famblat foriam

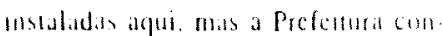
gelou o progtama para monlat a $113 \mathrm{~s}$.

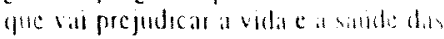
pessons" afirmon Evanla Rerle

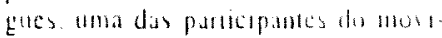
nemo De acorele com tela a irea ann

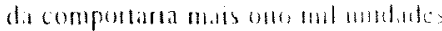
hubuticionals.

() vice presidente nacmol do Pl Alokio Mercadante que timben parn

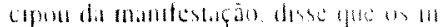

merabues que a lefentura quer mo

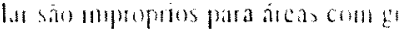

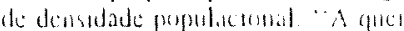

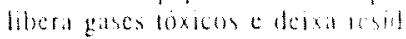

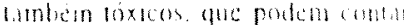
mar o soluc a igha" afomm

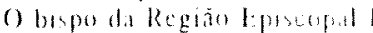
ken. d Decio Perent. disse que a jerisu da cammhada era exaltir a

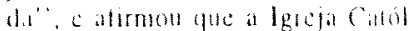
da Lona leste lutra past amped instabicano do moncrador. 

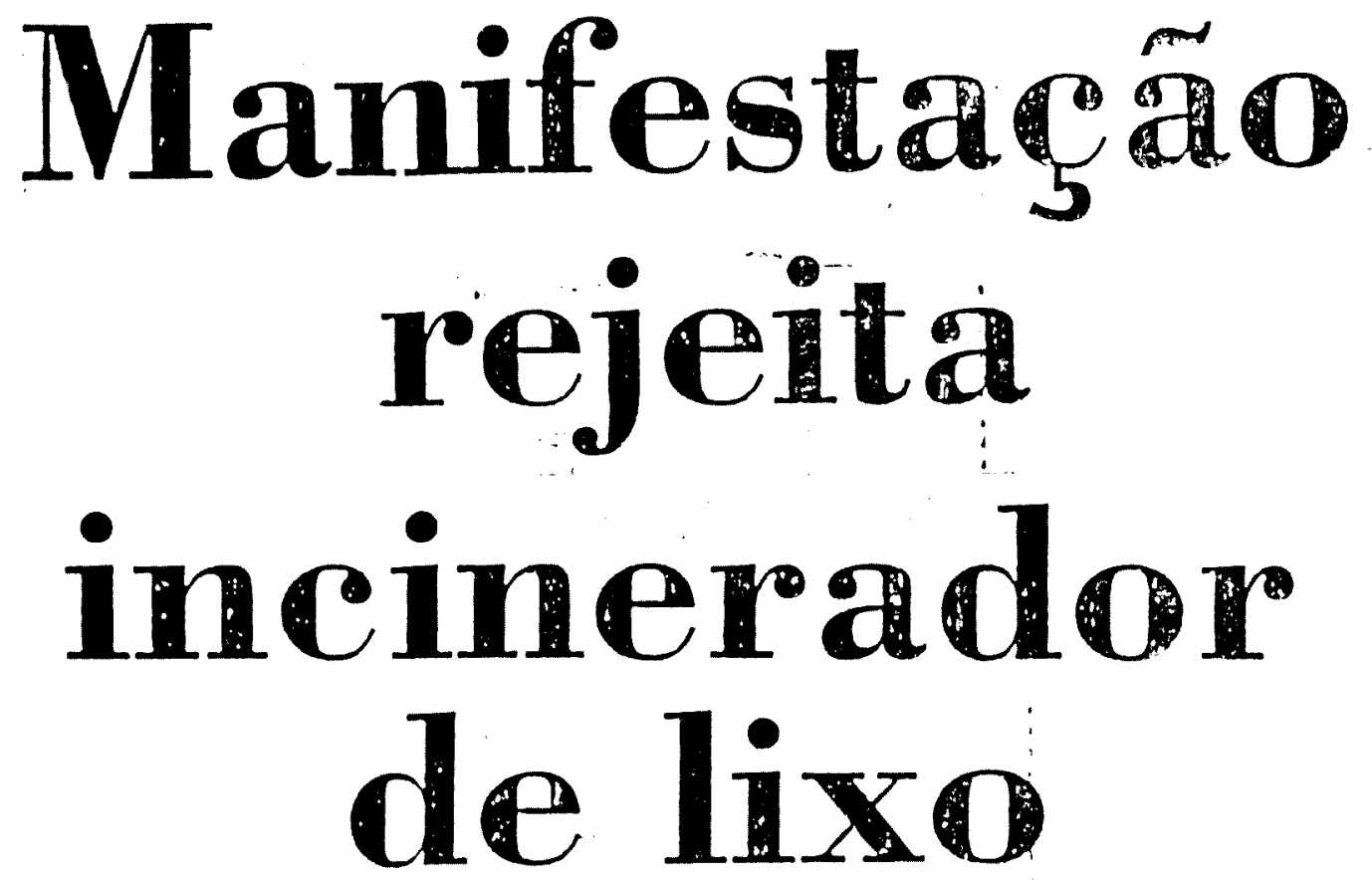

O Movimento contra a Instalação de Incineradores de Lixo na Cidade de São Paulo fez um protesto na entrada da usina municipal da Ponte Pequena, na Zona Norte, para marcar a passagem do Dia Mundial do Meio Ambiente. O ato reuniu 15 pessoas, entre ambientalistas. políticos e sindicalistas.

A técnica de incineração. de acordo com o movimento, prejudica a saude e o meso ambiente. pols produz elemenlos toxicos cancengenos (dioxinas e fu. ranos). A cinza resultante da incineraço do lixo. se sundo Célia Rerma Lou. redo Nogenno. representante do movi. mento em São Mateus, também é perigosa se năo tiver destinação adequada. "Essa cinza precisa ser entertada de forma especial. mas aqui na cidade ela e jogada nos aterros sanutários". explicou Célia Regina.

Durante o protesto. os manifestantes reivindicaram a desaluvaçăo da usına da Ponte Pequena. alegando que ela é perigosa e ulirapassada e rejeitaram a proposta da Prefeitura de instalar novos cquipamentos de incineraçào nos batrros de Sio Malicus (Zona Leste). Perus (Zona Oeste) E Santo Amaro Zuna Sul). "Esses incmeradores seráo cons- turidos $\mathrm{cm}$ areas de proteção ambiental ou perto de residencias", reclamam.

O movimento contra os incineradores defende o sistema de colcta seletiva e campantus cducauvas para que a população produza menos lixo. Segundo o deputado estadual Roberto Gouveta (PT), a queima de lixo é um processo $\mathrm{cm}$ decadencia nos paises desenvolvidos c nio se justifica sua ndoça $\mathrm{cm}$ Sĩo Paulo. O deputado tambem acusa a Prefeltura de estar desobedecendu a tel 1.817778 . que probe a instalaçio dos mencradores em zonas que najo sijam estntamente industnats.

\section{Diretor nega riscos à saúde}

O diretor do Deparamento de Lim. peza Urbana (Limpuros da Preforum. Paulo Gones Machodo. diminu que a usina da Ponte Pequena e ultranassada. mas negou que a populaça estena correndo riscos. "Nosso equipamento que incmera 100 tonetudas de ixo/da funciona a uma temperatura de 830 graus cennerados. o que imnede a worinaçao de dounas e climuna qualouer risco de conammacao." As doxinas. segundo o diretor do Limpurty. sino pro. duzidas somente en temperaturas abat-

\footnotetext{
ro de 400 eraus.

A coleta seleura segundo Machado. se adorada. nàn atungirsa mas do que 10\% do total de 10 mil ronelaciasida de lixo produzidas na Ciptal. Machado garantul que of novos incmeradores que a Prefenura pretente instalur sio segures e dotados de tiltros anudoluenles. Segundo cle a tomnaço de diok. mas prevista nesses novos equipamenos e de um bihonesmo de um grama (0.19 nanogramal. considerado mocuo.
} 


\section{Incineradores de lixo são idéia da gestão Erundina}

Os incineradores de lixo que a Prefeitura pretende instalar na Capital e que têm recebido muitas criticas são consequência de um estudo rcalizado na gestão da prefcita Luiza Erundina. A afirmação foi feila pelo secretário municipal do Verde e Mcio Ambiente. Werner Zulauf, durante o seminário Lixo Municipal e seu Gerenciamento Integrado, promovido pelo Instituto de Pesquisas Tecnológicas do Estado de São Paulo (IPT).

O secretário disse estranhar a resistência da população, segundo ele comandanda por iniegrantes do PT, porque a solução encontrada pela atual gestāo é baseada em diretrizes formalizadas pela administraçāo da prefeita Luiza Erundina. Werner Zulauf chegou a elogiar a iniciativa da ex-prefeita porque iniciou o processo para solucionar um grande problema que São Paulo vem enfrentando. "Não há mais cspaço físico para a construçāo de aterros sanilários e os que já existem estão saturados. A única solução sāo os incineradores". disse o secretário.

$A$ instalação dos incineradores faz parte do Programa da Macrorreciclagem apresentado pela Prefeitura e tem como objetivo minimizar o problema do lixo cm São Paulo. Além dos inci: neradores, esse programa prevé a co: leta seletiva, mas, segundo o secretário. a coleta só será implantada após a instalação dos incineradores, prevista para o prazo de dois anos. "A partir dal, vamos chamar a população para participar dando sua contribuição na separação dos lixos organico e do se co", concluiu o secretário.

\section{PLANO}

O ex-secretário de Serviços c Obras da administração Luiza Erundina, Márcio Junqueira, confirmou que foi elaborado um plano para solucionar o problema do lixo em São Paulo e que nele estava previsto a construção de incineradores. No entanto, Junqueira garantiu que o plano, que foi publicado nos últimos dias da gestão anterior. nāo previa o local nem a forma de concorrência para a construçâo dos equipamentos. "As criticas cxistem exatamente sobre esses dois pontos". afirmou o ex-sccretário. 


\section{Justiça suspende desapropriação de área em Perus}

A Promotoria de Jusuça do Mcio Ambiente da Capital requereu a suspensão do processo de desapropriaçào de uma área de 35 mil metros quadrados em Perus, encre as rodovias Anhanguera e Bandeiranies, proposto pela Prefeitura para a instalaçào de uma usina de compostagem $e$ incineraçào de luxo. alé a obtenção de licenciamento ambiental para a obra. A área foi declarada de utilidade publica arraves de decreto ern maio de $94-\mathrm{n}^{\circ}$ $34.174 / 94$ - mas ale agora não foi cla. borado o Estudo e Relatório de Impacio Ambiental (EINRIMA) demonsirando que aquele e o local mass adequado para a umplantaçáo de um incinerador e os $\mathrm{um}$. pactos que sua construçăo causarıam à regaảo, proxima a um parque.

Segundo o promotor de Justica Danuel Roberto Fink, sem a realização do estudo. a Prefeitura poderá cstar desapropnando uma area inuulmente. com possiveis danos ao parrimónio publico. "O estudo serve para determinar a melhor área de localizaçăo dö empréndimento. Como ele pode ainda nem ter sido feito e a Prefeilura já estar desapropriando?". perguntou. O Ministerio Público foi chamado a dar scu parecer no processo pelo juiz da $11^{\circ}$ Vara da Fazenda Pública. Lino Manoel Duarte Batusta Ribeiro, onde tramita a açào. O juiz determinou o envio do processo ao MP e à Comissão de Mcıo Am- biente da $O A B$ considerando o custo do terreno em relaçào às construçoóes.

En seu despacho o juiz Ribetro reque reu esclarecimentos da Prefeilura "sc nảo convuria mass ao interesse publico a expropração de árca bruta scm a obstru. ção de uma atividade empresarial". $\mathrm{Na}$ área de propriedade de Robeno Giacomo Grava existe uma fabrica de sebo para sabonete e de farinha de osso para ração animal. com tres casas $e$ dois barracöes. a João Gava e Filhos Lida, em que tra. ballum 180 pessoas. A Prefectura pensa cm pagar RS 2.2 milhöes, com base no valor venal, pela área. O custo do incine. rador, ainda não adquerido. é de USS ISO milhóes. Pelo contrato cabcria à cmpresa vencedora da licinação para umplantaçao da obra. rcalizar o EIARIMA. 


\section{Moradores abrem guerra!}

\section{contra incinerador de lixo.}

\section{LILIAN CIIRITOFOLETTI \\ E KATIA OGAWA}

Acostumados a conviver corn o mau cheiro e os ratos que vem do atcro santano Bandeirantes. em Perus, Zona Oeste, os morudores da regibo começam a se mobilizar para combater a ideia da Prefeinura de instalar no local duas ustnas incuneradoras. Segundo relatório do grupo alivista ecologico Greenpeace. o equipamento emite substancias alta menic corrosivas - como o kido clort drico - que podem causar até cancer. Imladoa, os moradores esla se organi: zando para impodir a insulaço das ust. nas e para desauvar o alerro sanilíio.

- Esilo nos colocando entre a faca e o revolver. Se necessurio, reagiremos com violencia contra o incinerador". promeleu o morador Afonso Braga, que lambem se queixa do descaso da Prefeitura em relaça aos problemas trazidos pelo lixo jogado na area. que afeta a saude da populaçlo. Ele espera uma soluçio do prefeito Paulo Maluf para os danos causados pelo alerro.

As situaçơes mals graves sắo en. frentadas pelas 30 famllias que se amontoam em barracos proximos ao aterro e utilizam a gua contaminada proveniente do lixo. Sto vitimas de doenças respiralórias e imiaçoes na pele e nos olhos. E o caso de Mana do Socorto dos Santos Silva. de 24 anos. que divide com outras 18 pessoas os 40 metros quadrados de seu bartaco. "E muito comum ter doenças de pele por aqui. meu imnso esta cheio de ca. rocos no corpo ", afimou.

$O$ aterro Bandeirantes. um dos maiores da Capital, recebe $151 \mathrm{mil}$ toneladas de lixo por més. o que equiva. le a 830 caminhoes por dia. Sua vida úil deve se esgotar em dois anos. $x$ gundo informaçoes da Prefeitura. A saida encontrada pelo Municipio foi a instalaço dos incineradores que. na opinido do secreiario municipal do

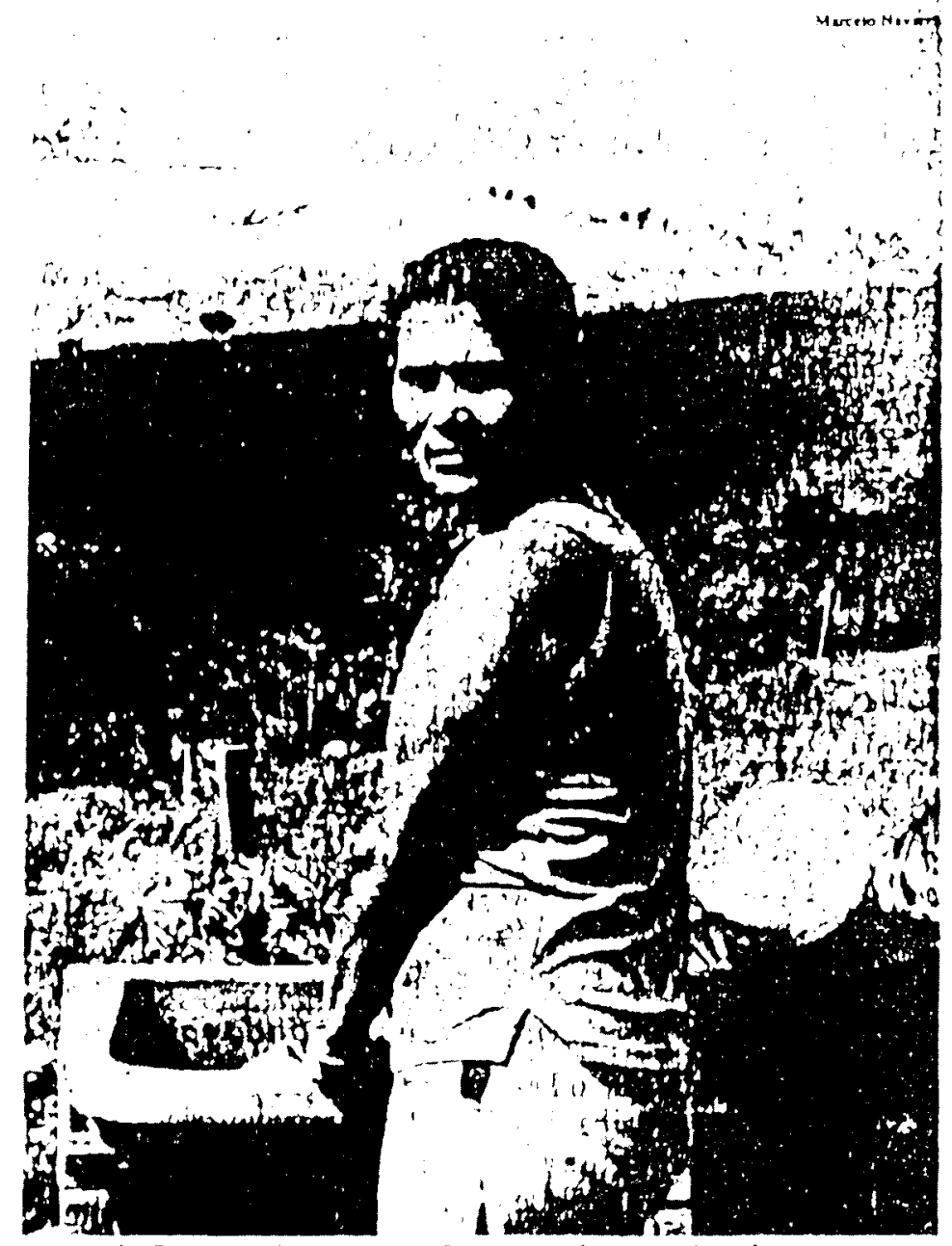

Maria do Socorro, de 24 anos, afirma que doencas de pele sdo comuns

Verde do Meio Ambiente. Wemer Zulauf, săo grandes unidades de reproduçıo energetica.

Para Paulo Andrade. da Comissăo do Meio Ambiente da Ordem dos Adrogados do Brasil (OAB), a proposia da Prefeltura é autoritána e ilegal. "Vai colocar em nisco a populaça" alertou. $O$ assessor de Meio Arubiente do ve reador Adriano Diogo (PT.SP), Sérgin Noperno, concorda com essa avaliaç e garante que os gases emitidos pelo incinerador causam cancer, alem de dis túbios imunológicos. Zulauf nåo concorda com os argumentos e afirmou que a quanudade de $\mathrm{g}$ ás toxico liberach pelas usinas $t$ "absolutamente irtele vanic em termos de emissalo".

\section{Equipamento será importado}

Os incineradores sao condenados nos paises da Europa e da America do Norte, segundo Sergio Nojerno. Para o secretario Werner Zulauf "isso é mentira do Greenpeace" . Segundo ele, apenas os incineradores antigos estao sendo desativados no Exienor, por serem nocivos a saude da populaça. $O$ secretario esclareceu que os futuros in. cineradores de Perus sao modernos e nalo colocam em risco a natureza nem a saude da comunidade. Eles serdo responsáveis pela queima de 1.250 toneladas de lixo por dia.

Imponados da Alemanha cada incinerador esia avaliado em USS 100 milhoes. segundo a assessoria de im. prensa da Secretaria Municipal do Verde e do Meio Ambienie. "Esse dinheiro nao saira dos cofres publi. cos. mas de empresas privadas que usam o aterro, atraves de concorrèncla publica" assegurous o diretor do Departamento de Limpeza Uibana
(Limpurb). Paulo Gomes Machado.

Náo há previsao para a instalaça. Segundo Machado, o auraso deve-se a escolha dos ierrenos para implantaç do das usinas. Duas areas ja foram previamente definidas. A primeira delas $t$ na esirada Anhanguera-Perus $e$ a ou. tra. que perience ao Banespa. fica pró xima a alual usina de compostagem. na todovia dos Bandetrantes.

(Projeto reporter 2.000). Obork Proletos Especinta. 


\section{Zonas Sul e Leste vão ganhar incineradores}

A Prefcitura vai iniciar ate junto a construçðo das usinas de incincraçào de lixo cm São Matcus, Zona Leste, $\mathrm{cm}$ Santo Amaro, Zona Sul. O anúncio foi feilo ontem pelo secretário municipal do Verde e Mcio Ambiente. Wernet Zulauf, durante debate com vereadores e entidades de moradores na Camara Municipal sobre o problema do trataincrito do lixo na Capital.

O projelo da Prefcilura. conludo. cnfrenlará dificuldades para ser implantado. O presidente da Ceicsb. Nelson Nefussi, disse que nenhuma usina poderá ser implantada scm autorização da cmpresa. e o pedido da Prefeitura nem scquer foi cncaminhado. Alén disso, os vercadores e os moradorcs das árcas próximas aos futuros incincradores prometcm resistur à instalação.

"Os incincradores são allamente polucnics as toxinas podem provoca cAncer', disse ò vercndor Adriano Diogo (PT), um dos organizadores do - cvento. Scgundo Djugo as soluçocs pa ra destinaçdo do lixo sáo a colcta sclctiva. a reciclagem e a ampliagajo dos atcros. Os participantes tamberm cxigiram a desativação imcdiala das usimas da Ponle Pequena e na Água Funda. instaladas há mais de 40 anor.

Scgundo o sccretário, us incincrado. res sujo neccssários porque näo há mais cspaço físico para novos atcros sanitários c os que já cxisicm estão saturados.
"Hloje, a tecnologia permite a instala. fijo de incincradores sem incômodo", defendeu. Zulauf argumenta tamberm que a incincração é a mchor opção para o lixo hospitalar. Ele disse anda que cstá de pieno acordo com o fechamento dos incineradores antigos, mas isso só deverá ocorrer em dois anos, depois que as novas usinas estiverem funcionando.

Pan Zulauf, a populaçjo não csía conra os incincracores. "Sస̃o só meia dúzia". afirmou. As duas novas usinas serato construidas por consórcios de cmpresas. que vão adnimistrá-lis por 20 anos.

Célia Regima Nojerino c Nair. Alves Rezende Norimbeni, integrantes do Movimento contra Incincradores de São Malcus, disse que os moradores năo vão pcrmitir a construção da usina. "Sc for preciso, vamos desmanchála". disse. Segundo o vereador Adriano Diogo, uma ação popular contra os incincradores está tramitando na Justiça. DISCUSSÃO

O início da instalação dos novos incinerndores de lixo na cidade pode criar outra discussajo cutre a Prefcitura e u Governo Estadual. O major problcma e o valor da taxa que as empreitciras têm de pagar para cutrar com o pedido de licença na Cetesb: $0.5 \%$ do investimento, ou aproximadamentc R\$ $750 \mathrm{mil}$ para cado incinerador. "Esle valor é incrivelmente alto", afimou Zulauf Segundo cle. a Prefeitura cstá neguciando um novo valor da taxa. 


\section{Justiça liber'a obras de usinas incineradoras}

O Thibunal de Justiga (T) confir. mou decisdo que libera os obras de inslalaçao do duak usinas incineradoras na Caplial. A decisao fol tomada pela S'Camura de Direlio Publico que IndeCeriu recurso (agravo de instrumento) prepusio por 97 persoas que assinam uma aço popula conira o municipio. O advogndo Anconiu Femando Pinticlto Pedro alega que houve irregularida. des no processo de licilaçarn.

An duas usinas esian ssuadas em Sa. pupermita, Zontia Leste, e Santo Anunro, Zona Sul. Segundo a Prefeilurn, clas vo queimar jumas 2.4 mil roncladns de lixn. do tolal de 12 mil produridus diariomente. A licilaça do que exta sendo conlestada na Justlf: fol aberta cm norember de 199.3. A concorrencia foi goncludda $\mathrm{cm} 19 \mathrm{re}$ abril de $1974 \mathrm{com}$ - vilorla dor consórclos EicicuidDe Bartulorge e Veyt-SupareAturin. 0 pilimeiro fićnu cuin a congtruça da usina de Samo Amaru. entepanto'o se. gundo com a de Supapeniba.
Aluda segundo a Prefcilum cade usine esif orgade em USS 150 nلlhoet. O financiasuento foi oblido por consorclos em bancos do Bxiertur. A Prefeliura fol a avallsta do financianellio usando para tsso a taxa do limpeza urtana. Pelo con. trato, as empresas constrocin as usinas $e$ em troca pridem operi.las pelo prazo de 20 ancos. Depols desse periodo, as uslnas passann a petiencer ao Municlplo.

O ndvogado Femando Pinhciro Pe. dro alega que, alem das inegularidades "ia licilaça, insialaça dos licinera. dnres val colocar em perigo a vida e a saude los moradoros das áreas pioxj. max. Segundo ete, o perigo se dard pela exprsiçá ds dioxinas (substalicias pro duzidas prineipalmene pela queima de produtos coino cloro, plástico e papel).

I'or volacto unanime. o g" Camara de 7 Trello Publlico enlenilen que as ubras nán valo provucar danos litepaThvels e negou o pedido de lininur. Agora. a acto Junlclal volla a Iramilar na $5^{\prime}$ Vara da Facenda Fublica. 


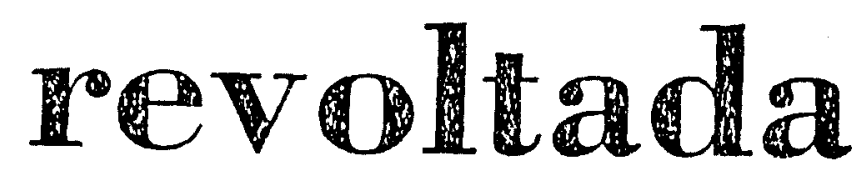

Apesar dos protestos de moradores. ambientalistas $c$ de o caso estar sendo conlestado na Justica. o secrctirio municipal do Verde a Melo Ambiente, Wemer Zulaut. concedeu licença am. biental para a constriçito de dois incint radores de lixo - um em Santo Amaro. Zona Sul, e outro em Sāo Mateus, Zona Lesia. A autonzaçāo revoltou a populacăo. que promete fazer ludo que for possivel para evilar as obras. Em Sao Mateus, os moradores prometem até acampar no local ondi o equipamento sera constnuilo. A ubra orçitua em USS 100 milhōes, devera ter incio no pri. meiro trimestre do ano que vem.

"Nào permuturemos esse incincrador de forma alguma. Vamos ate acampar na area. Isso seris a destruição do nosso banto e das cidades vizinhas", afinnou o tecnólogo Sirgio Paulo Nojen. de 46. que mora no bairro há 17. Ele garaniii que há estudos internaciona!s provando que esse tipo de equipamento podi cátusar graves problemits à saude, como cân. cer e mulaçōes gencticas te honnonais.

Indignada esia a moradora Olimnia de Melo Silva. de 55, cuja casa lica a menos de dois quilonetros do futuro incinerador. "Nio precisamos desse cyuipamento A pupulaçáo ja e duente porque njo tem um alcendimento de salude publico indetpiado, esse incincta dor so val prejudkiar alldia mals una regra bastante casiggadi", avaliou. Ela acrescentou yise o batro ja sofic com a poluiçảo que vem do pólo petroqumico ém Maua, região do Grande $\triangle B C$. que fica a menos de cmco quilometros do bairro. Nar Alves Norembene, do Movimento de Saude. garantuu que d construçāo natu lera micuo " Vamos fa. zer fudo pana impedir, o gue for prece so. E uma imoralidale construr esse 11 po de obra ao lado da populaçào" avaliou. No local onde deverá ser instalado o incinerador hi una escola de cduca. ço infantil c um posto de saude.

A determunaçáo do Depantamento de Controle da Qualidade Ambiental, da Secresaria Municipal de Verde c Meio Ambicnte, que autonza a instalaçào, fol publicada quarı-feira no Diáno Oficial do Municiplo. Em 1995 a secrelana ji havia concedido a licença ambiental previlt promeira fase do programat. que está sendo contestada ha Justeça por um processo de açào popular inupetrajo por I 50 moradores da regiño Lesta. "Con ceder a segunda licença é numfo estua. nho e inoral. O secretario conce o risco de ser responsabilizato ate pessoalmente pelos prejuizos que a Prefciturá pode ter". disse o advogado Antonio Fermando Pinheiro Pedro. pressefence di Associaçĩo dos Advogados Ambientalistas $\mathrm{c}$ da Comissajo de Meio Ambiente da Ordem dos Advogados do Bras!! (OAB-SP), que deu culrada na ação. -O secretairo nào poderia dar a segur. da licença. cle tena de esperar a decisào da Justica", acrescenton

Segundo cle, o ag gumento utilzzikio na aça foi de glue os inconeradores nāo por. dem ser licenctados pelo musnicinto pros.

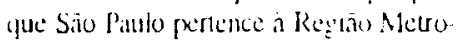
polstana e uma obra como esta causa im. pacto ambientat em loda a arca. $A$ açión alega lamben que o estudo de minacto ambiental for festo antes da escolha dus localis a serem instalados. O Minstirio

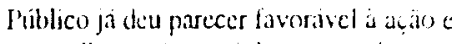
aconselhout o jute a julgar proccuente a responsabididide dos convolvider. 


\section{Zulauf diz que cumpre a lei}

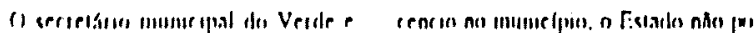

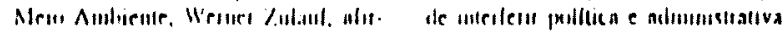

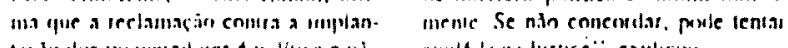

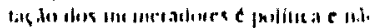

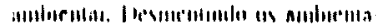

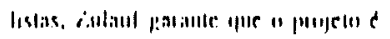
ale ietial senutang "Os fudice de pa.

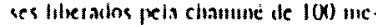
twes de aluma tem inquacto urelevante.

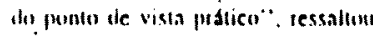

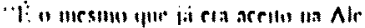

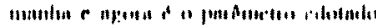

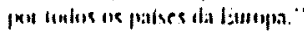

(1 secréstul garminu que está ies paldado legalmente. File dis, que a iesn.

lacilu do Cimselluo Nacimal do Mew

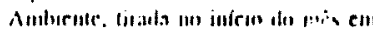
friasilas. peimule au municipon legisiar wotue quessies ambetsams "Se $\mathrm{cu}$ h. 


\section{Falta de aterro para lixo ameaça Capital}

\section{MOACHIASSUNCAO}

A coleta e e tratamento de hxo na Kegata Metropolntana, com 17 mi-

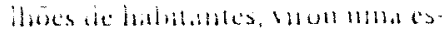

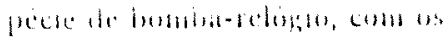
antondades canpurtando o problemid para as sucessores. Por bso, especintistas prevecm an m-

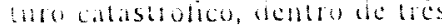
anos ghandu a capdenade dispo-

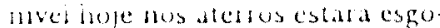
fadia. Liles alc projetan conflitos diretos entre a populaça e as all-

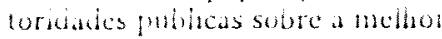
destinacáo do lixo

So a Caphas, conn uma popuh. câo em tomo de 10 milhoes de habitanes, praticanchle nào lem mils espaçus para colocat as $15 \mathrm{mil}$ toneladias de asiduos produzidos diarianente Os uncos dols atedros de que a chiade dispoe, u Bandemantes, em Perus, Zona Ouste, c o São João, cm Sĩo Mateus, Zona Lesic. tem via bul de, no maxtmo tres anos lara completar. pra-

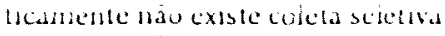
e aghmals ab fillmas areas veldes, gue poderam farander qualidade de vida a populaçao, estao sendo havadidas por lixós datrdestuos e lobanentos arregulares

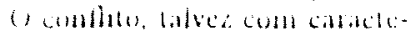
bisticas semellantes ao previsto por entudades internacionas pelo controle das fontes de agua, ja po-

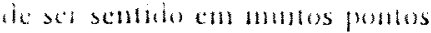

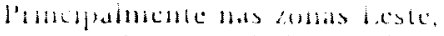
Nonte Oesie, onde lixotes chadestuos são sempre localizados pela Prefollata e pela Cetesh, al-

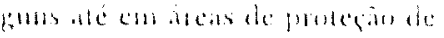

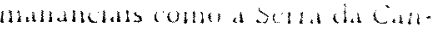
tarena e as matgens das a curesas Bllangs e Guaraphanga. Ela al guns casos, viglas armatios os protegem, mamidamo liscals

lia conco anos, quandio a l'refelura tenon uthata atemo de

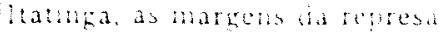

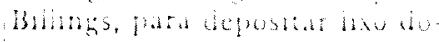

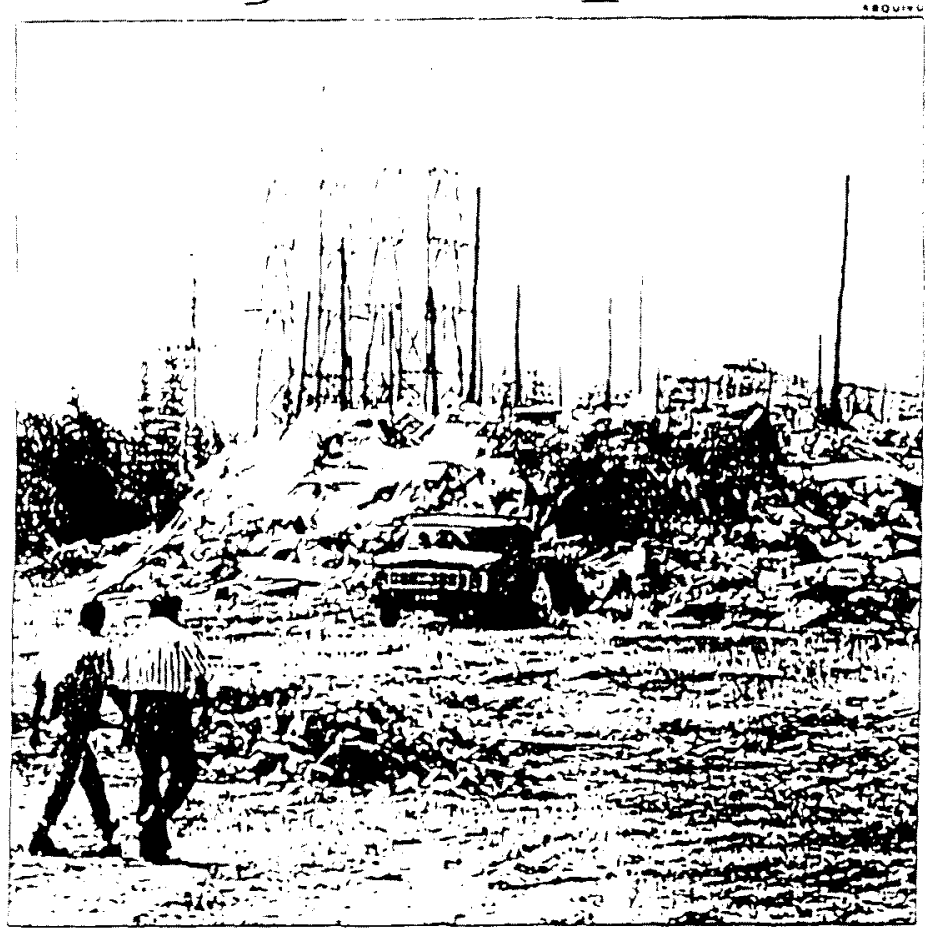

ESPECIALISTAS dizen que nào há lugar para is mal tonelados diárias

mestico, a populaço reagu cm redudetra bahalia campal e chrou cur chuque com a Guarda $\mathrm{Ci}$ b) Metropulitiana, desimandio o ateras. Somente depors de acomio chlle as pattes, se voltou a deposllar cntulho no local.

\section{Linites}

Vale lembrat que, al ivorte, is chade elimada pela berra da Canbiscira, ja munto degradida, c ao Sul pelas areas de protecão mabental das represin billabs e

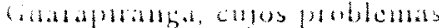

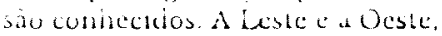
a quase total ocupacio dos terre nos, alem de faxas a mata da Cantareira, mupossbilitam a insialaşú de alertos.

lara porar a stuagán, chequan-

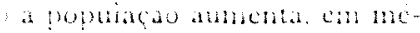

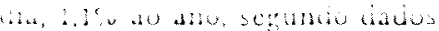

Ju Instatuto Brasileiro de Geogratia e Estutistica (IBGE), a produఢ̧ẫu di lixo cresce em proporçōes cincu veles majores, ou seja. $6,30 \%$, numeros que uumenla‘un com a estabilidade econònca do ithono Real.

"Ou a colcta pública vai parar un vames ter de jogar o lixu etia abum ingar, porque os resíduus nāo vão desaparecer", alertou o tecnico da Cutesb, Pedro l'entea(io. O) pesquasudor do Centro de listatius de Cuitura Contemporinea a professor de Sociologia da Unip. Marcos Teixcira, considera que, a mécio prazo, a situagáa pode ficar muito complicada. "Poccmos tor um conlitio generahzacio caso haso se tomem providenculs coerentes com a gravida-

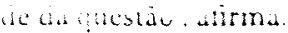


Anexo 2 - Levantamento de fontes por matéria publicada no jornal Diário Popular 


\begin{tabular}{|c|c|c|c|c|}
\hline $\mathrm{N}^{\prime \prime}$ & Título: & Data: & Classificaçào da fonte: & Número de fontes \\
\hline $1^{\circ}$ & Incinerador & 270494 & - Politico em oposiçào & 1 \\
\hline 20 & $\begin{array}{l}\text { Usina de lixo sera teita no } \\
\text { parque Anhanguera }\end{array}$ & $2405 / 01$ & $\begin{array}{l}\text { - Politico em oposiçào } \\
\text { - Orgão governamental-proponente }\end{array}$ & 2 \\
\hline $3^{\circ}$ & $\begin{array}{l}\text { Usina de incineração de lixo } \\
\text { causa Protesto }\end{array}$ & $2905 / 94$ & - Movimentos Sociais & 1 \\
\hline $4^{\circ}$ & $\begin{array}{l}\text { Moradores levam prato de lixo } \\
\text { para secretario }\end{array}$ & 090694 & $\begin{array}{l}\text { - Movimentos sociais } \\
\text { - Orgão governamental-proponente } \\
\text { - Politico em oposiçào } \\
\end{array}$ & 3 \\
\hline $5^{\circ}$ & $\begin{array}{l}\text { Malut quer incineradores de } \\
\text { lixo em toda cidade }\end{array}$ & $16 / 06 / 94$ & - Politico Favorável & 1 \\
\hline $6^{\circ}$ & $\begin{array}{l}\text { Usina de incineraçào de lixo } \\
\text { causa protesto }\end{array}$ & $30 / 06 / 94$ & $\begin{array}{l}\text { - Movimentos sociais } \\
\text { - Órgăo governamental-proponente }\end{array}$ & 2 \\
\hline 7 & O cartel do lixo na cidade & 290794 & $\begin{array}{l}\text { - Politico favoravel } \\
\text { - } \quad \text { Movimentos Sociais } \\
\end{array}$ & 2 \\
\hline 8 & O lino e a demagogia & 080894 & $\begin{array}{l}\text { - Politico em oposiçào } \\
\text { - Politico Favoravel } \\
\end{array}$ & 2 \\
\hline $9^{\circ}$ & $\begin{array}{l}\text { Secretario Promete resolver } \\
\text { problema do lixo com usinas }\end{array}$ & $2608 / 94$ & - Orgão governamental-proponente & 1 \\
\hline $10^{\circ}$ & $\begin{array}{l}\text { Zona Leste recusa combustào } \\
\text { de lixo }\end{array}$ & $2809 / 94$ & $\begin{array}{l}\text { - Movimentos sociais } \\
\text { - Orgão governamental-proponente }\end{array}$ & 2 \\
\hline $11^{\circ}$ & $\begin{array}{l}\text { Protesto contra usina despeja } \\
\text { lixo na Câmara }\end{array}$ & 2809994 & Movimentos sociais & 1 \\
\hline $12^{\circ}$ & $\begin{array}{l}\text { Moradores contra incineradora } \\
\text { de Valuf }\end{array}$ & 241094 & - Movimentos sociais & 1 \\
\hline $13^{\circ}$ & $\begin{array}{l}\text { Protesto marca audiencia } \\
\text { sobre usina de lixo }\end{array}$ & $26 / 11 / 94$ & $\begin{array}{l}\text { - Movimentos sociais } \\
\text { - Empreendedores } \\
\text { - Orgào governamental-proponente }\end{array}$ & 3 \\
\hline $14^{\prime \prime}$ & Incinerador & 301194 & - Político em oposiçào & 1 \\
\hline $15^{\circ}$ & $\begin{array}{l}\text { Moradores protestam contra } \\
\text { lixo }\end{array}$ & 011294 & $\begin{array}{l}\text { - Movimentos sociais } \\
\text { - Orgào governamental-proponente }\end{array}$ & 2 \\
\hline $16^{\circ}$ & $\begin{array}{l}\text { Prefeitura mantem aterro } \\
\text { usina de lixo em Perus }\end{array}$ & 091294 & $\begin{array}{l}\text { - Orgão governamental-proponente } \\
\text { - Movimentos sociais }\end{array}$ & 2 \\
\hline 17 & $\begin{array}{l}\text { Adiada votaçào de relatorio } \\
\text { sobre incineradores de lixo }\end{array}$ & Jan. 95 & $\begin{array}{l}\text { - Movimentos sociais } \\
\text { - Orgão Governamental - regulador } \\
\text { - Organização não governamental } \\
\text { - Orgão governamental - proponente }\end{array}$ & 4 \\
\hline $18^{\circ}$ & Protesto contra incineradores & 060195 & - Movimentos sociais & 1 \\
\hline $19^{\circ}$ & $\begin{array}{l}\text { Cades aprova instalação de } \\
\text { incineradores de lixo }\end{array}$ & $14 / 01 / 95$ & $\begin{array}{l}\text { - Orgào Governamental - regulador } \\
\text { - Empreendedor } \\
\text { - Orgão governamental-proponente }\end{array}$ & 3 \\
\hline $20^{\circ}$ & $\begin{array}{l}\text { Manifestação critica usina de } \\
\text { lixo na região de perus }\end{array}$ & 260195 & $\begin{array}{l}\text { Organizaça não governamental } \\
\text { - Movimentos sociais }\end{array}$ & 2 \\
\hline $21^{\prime \prime}$ & $\begin{array}{l}\text { Moradores entram na justiça } \\
\text { contra incineradores de lixo }\end{array}$ & $1503 / 95$ & - Movimentos sociais & 1 \\
\hline $22^{\circ}$ & $\begin{array}{l}\text { Sào Mateus protesta contra } \\
\text { incinerador }\end{array}$ & 100495 & $\begin{array}{l}\text { - Movimento social } \\
\text { - Político em oposiçào } \\
\end{array}$ & 2 \\
\hline $23^{\circ}$ & $\begin{array}{l}\text { Manifestação rejeita } \\
\text { incinerador de lixo }\end{array}$ & $06 / 06 / 95$ & $\begin{array}{ll}\text { - } & \text { Movimento social } \\
\text { - } & \text { Político em oposição } \\
\end{array}$ & 2 \\
\hline $24^{\circ}$ & $\begin{array}{l}\text { Incineradores de lixo são idéia } \\
\text { da gestão Erundina }\end{array}$ & $09 / 06 / 95$ & $\begin{array}{l}\text { - Órgão governamental-proponente } \\
\text { - Politico favorável }\end{array}$ & 2 \\
\hline
\end{tabular}




\begin{tabular}{|c|c|c|c|c|}
\hline $25^{\circ}$ & $\begin{array}{l}\text { Justiça suspende } \\
\text { desapropriação de área em } \\
\text { Perus }\end{array}$ & 250895 & $\begin{array}{l}\text { - Empreendedor } \\
\text { - Orgào governamental-regulador }\end{array}$ & 2 \\
\hline $26^{\circ}$ & $\begin{array}{l}\text { Moradores abrem guerra } \\
\text { contra incinerador de lixo }\end{array}$ & $05 / 1295$ & $\begin{array}{l}\text { - Organização não governamental } \\
\text { - Movimento social } \\
\text { - Orgão governamental- proponente } \\
\text { - Politico em oposição }\end{array}$ & 4 \\
\hline $27^{\circ}$ & $\begin{array}{l}\text { Zona sul e leste vào ganhar } \\
\text { incineradores }\end{array}$ & 200496 & $\begin{array}{l}\text { - Orgào governamental-proponente } \\
\text { - Orgào Governamental - regulador } \\
\text { - Politico em oposição } \\
\text { - } \quad \text { Movimento social }\end{array}$ & 4 \\
\hline $28^{\circ}$ & $\begin{array}{l}\text { Justiça libera obras de usinas } \\
\text { incineradoras }\end{array}$ & 1105997 & $\begin{array}{l}\text { - Orgào Governamental - regulador } \\
\text { - Órgão governamental- proponente }\end{array}$ & 2 \\
\hline $29^{\circ}$ & $\begin{array}{l}\text { Incineradores deixam } \\
\text { população revoltada }\end{array}$ & $26 / 1297$ & $\begin{array}{l}\text { Orgão governamental- proponente } \\
\text { - Movimentos sociais } \\
\text { - Orgão Governamental - regulador }\end{array}$ & 3 \\
\hline $30^{\circ}$ & Zulauf diz que cumpre a lei & 261297 & $\begin{array}{l}\text { - Orgão governamental- proponente } \\
\text { - Politico em oposição }\end{array}$ & 2 \\
\hline $31^{\circ}$ & $\begin{array}{l}\text { Falta de aterro para lixo } \\
\text { ameaça capital }\end{array}$ & 300998 & $\begin{array}{l}\text { - Orgão Governamental - regulador } \\
\text { - Empreendedor }\end{array}$ & 2 \\
\hline
\end{tabular}


Anexo 3 - Cópia das matérias publicadas no jornal Folha de S.Paulo (1994 a 1998)

\section{Ordem Cronológica}




\section{Folha de \\ S. Paulo}

\begin{tabular}{|c|c|}
\hline DATA & TÍTULO \\
\hline $04 / 02 / 94$ & Concorrência do lixo fere lei de licitação \\
\hline $10 / 02 / 94$ & Prefeitura suspende o "embargo'" do lixo \\
\hline $11 / 02 / 94$ & Três empresas entram na licitação das usinas \\
\hline $10 / 04 / 94$ & S P recicla apenas $0,06 \%$ do lixo produzido \\
\hline $26 / 05 / 94$ & Moradores protestam contra usina de lixo \\
\hline $20 / 06 / 94$ & Cidade importa incinerador de lixo \\
\hline $20 / 06 / 94$ & Ambientalistas apontam risco de Câncer \\
\hline $30 / 06 / 94$ & Protesto reúne 1500 contra construção de usina de lixo \\
\hline $02 / 07 / 94$ & Prefeitura será "avalista" de coletora de lixo \\
\hline 16/09/94 & Estudo condena incinerador \\
\hline $01 / 10 / 94$ & Teste em cobaias comprova risco à saúde \\
\hline $01 / 10 / 94$ & O lixo em São Paulo \\
\hline $15 / 12 / 94$ & $\begin{array}{l}\text { Decisão do BC atrapalha plano de incineração da } \\
\text { prefeitura }\end{array}$ \\
\hline $19 / 12 / 94$ & Zulauf defende usina que antes atacava \\
\hline $21 / 03 / 95$ & A reciclagem do lixo \\
\hline $22 / 03 / 95$ & Especialista faz crítica a incineradores de lixo \\
\hline $21 / 08 / 95$ & Gás de incineração pode causar Câncer \\
\hline $21 / 08 / 95$ & Maluf quer usina ao lado de parque \\
\hline $18 / 09 / 95$ & $\begin{array}{l}\text { Aterros da prefeitura só têm capacidade para mais } 3 \\
\text { anos }\end{array}$ \\
\hline $30 / 06 / 96$ & O que é incineração? \\
\hline $27 / 08 / 96$ & A ameaça dos residuos urbanos \\
\hline $29 / 10 / 96$ & Lixo hospitalar pode ter novo tratamento \\
\hline $30 / 10 / 96$ & $\begin{array}{l}\text { Cidade sofre com falta de locais para colocar suas } 17 \\
\text { mil t diárias de lixo }\end{array}$ \\
\hline $14 / 01 / 97$ & Dos males, o incinerador é o maior \\
\hline $11 / 04 / 97$ & Sobre a incineração \\
\hline $06 / 02 / 98$ & Fentograma \\
\hline $24 / 06 / 98$ & A coleta seletiva simultânea \\
\hline $04 / 10 / 98$ & Aterros de S P se aproximam da saturação \\
\hline
\end{tabular}




\section{Concorrência do lixo fere lei de licitação}

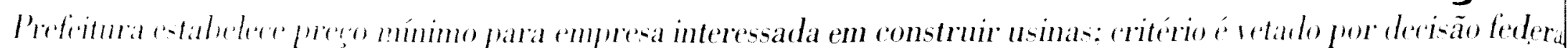
LUIS HENRIQUE AMARAL
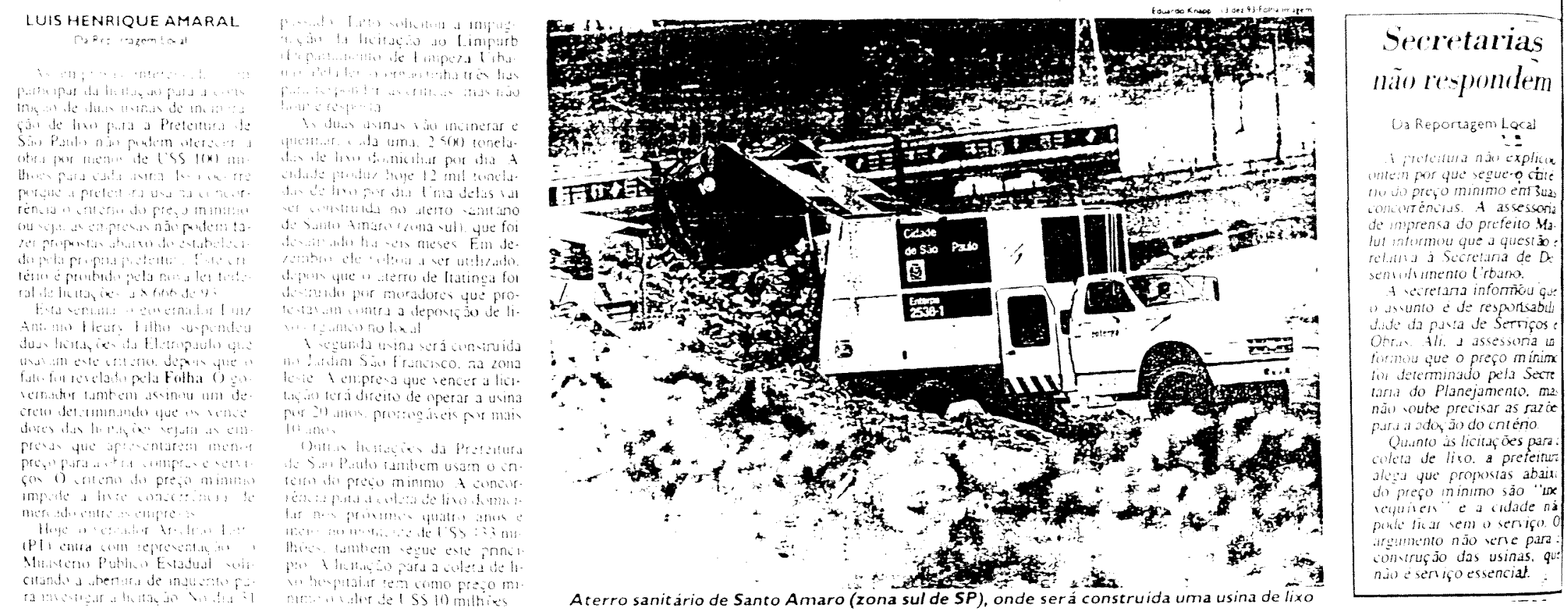


\section{Prefeitura suspende o "embargo" do lixo} Empresa que ganhou ação contra licitação volta a ser paga LUIS HENRIQUE AMARAL

\section{OA Reporagem loca}

A pretertura anunciou onem a theracio do pagameno de USS (c) inil para a thopesa Splice, yue realiza a coleta de lixo ha Penta zona oeste). A cmpresa teve seus pagamentos suspensos nos meses de dezembro e janciro. Segundo o Jiretor-presidenic da cmpresa. Antono Beldi. a suspensao dos paga. mentos to uma "retaltaçao" da preteitura contra a Spice.

O molivo da retaliacio teria sido as Immnares obtidas na Jusuca pelo empresa suspendendo as lievaçoes municipass para a coleta de lixo comum tho valor de US\$ $433 \mathrm{~m}$. thoesl c para a coleta de lixo hosptalar tde USS 10 mithoes).

Nos dors casos, Beldi acusa a prefelura de lavorecer as empresas que tormam o chamado "cartel do lixo". "Esta suspensäo e llegal. Estamos sendo myesugados ha um mes e mato e nada lol enconurado contra nos", diz Beldi. Segundo ele. a preficiura anda năo deposi. tou os pagamentos. A licitaça para a coleta de lixo comum e a mator em andamento no Brasil.

Ontem. a assessona de imprensa do secretano Reynaldo de Barros. do Desenvolvimento Urbano, informoti que as pagamentos para a Splke foram suspensos porque at cmpresa esta sotrendo uma nuestigacio de rouna. que anda no ter muru. Quanto aos pagtmentos. a petchura mformou que eles iram. lam ha Secretara das Financas c devem ocorrer nos proximos dias.

O juiz Jose Marcio do Valle Garca. da 3" Vara da Fazenda. concedeu liminar na semana-passada para outra empresa do grupo de Beldi. a CRTS (Companma do Redes Teletomicas Sorocabanat. suspendendo a lichacao para a 60. leta de lixo hospitalar i pretetura anda csia preparando sua detesa para tentar derrubar a liminar

Em dezemoro. \& Splice obteve una liminar contra a hichaca para a coleta de lixo domediar na cidaLe. mas da for derrubada por deciSo do Trbenat de Justica As propostas kemlas centio aendo andiadas to resunado da homatio de-

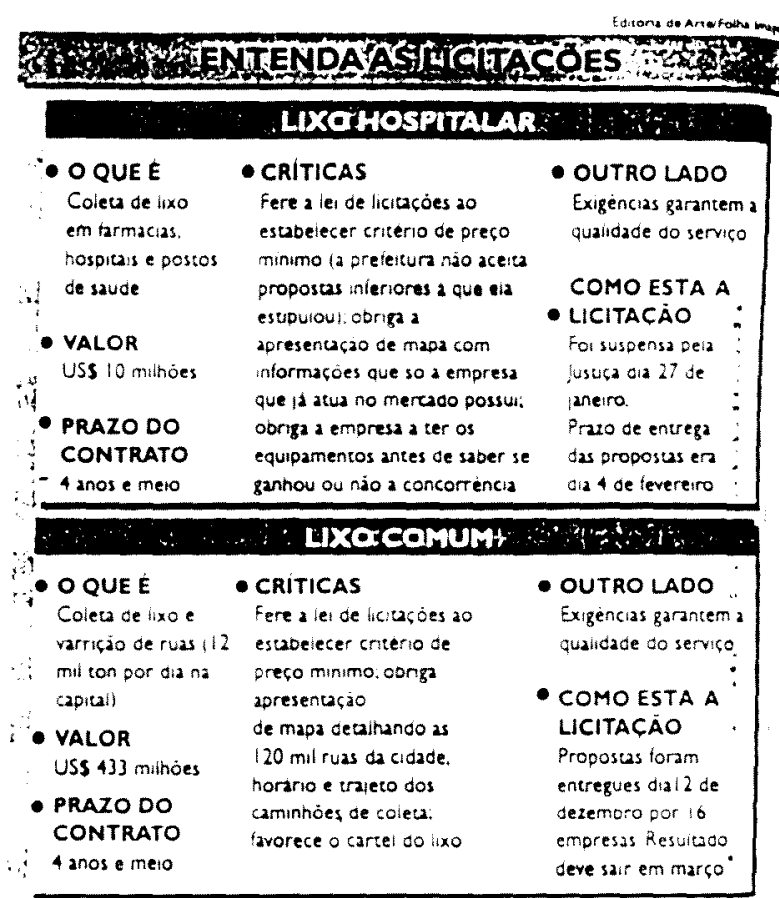
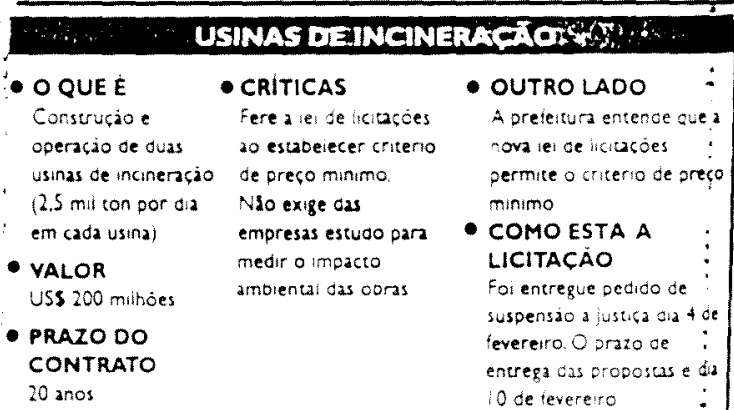

c ser divulgajo no proximo me.

\section{Usina}

$O$ vereador Adnano Drogo PT antrou ontem com representacio na Vara do Mero Ambiente do Mi insterio Publico Estadual sohicanto que sela inveshgada a lichaço pard a construçio de duas usinus

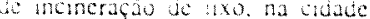

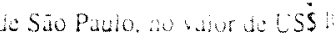
mihoes caja una

A aberura dus proposas par construcio das usma cora amm $\checkmark a$ representicioso éc atima aue dital nio sutfinou dus cmprest execuçio do Relitono de Impur. tmbtentit. camo setermint Consuturgo. 


\section{Três empresas entram na licitação das usinas}

Da Reportagem Local

Tres consorcios apresentaram propostas anlem para participar da concomencia para a construçáo de duas usinas de incinerasuo de lixo em San Paulo, Cada usma lem pre(1) estimado ent USS 1111 ) milhoes e deveri processar 2.5 mil tomeladas de livo por dia. A cantal produz 12 mil lonelada por dia.

Tres empresas hrastleiras. acompanhadats por llos estrangejros. formatram os consorcios. A Vegat-Sunate. que atual ma area de coleta de livo. x" arvichas at francena compagne ciencrale de Chatule. A ellinpeleira Elesco se associou a De Bartolomeis. c a Enterpa. yue lambem realiza coleta de lixo. contron junto com a Von Rool America lix..

Ontem lamben. " vercador Ar. chlmo Tallo (PT) colnon com re-

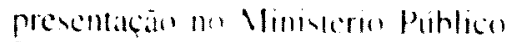

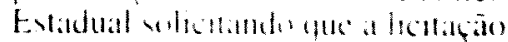

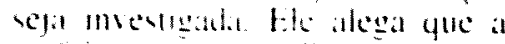
preleitura ana me edital a criterio do preço minmmon. all seit. as ('m-

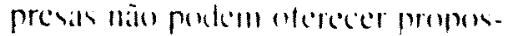
las abaino dox l's, flin mullowes dekemmados pela prevellura.
Segundo Tallo. este critério tere a nova lei de licitaçóes. que determina que a proposta vencedora seja a que oferece o preço mais vantajoso. Na sua representação. ele lembra que o govemador Luiz AnIomio Fleury Filho anulou. na semana passada. duas licitaçoes da Eletropaulo que usavam o critério do preço minimo.

\section{Retaliação}

() diretor-presidente da Splice. Intonio Beldi. afirmou ontem que a prefeitura ainda não pagou os USS 600) mil reterentes a coleta de lixo no bairro da Penha izona les(e) nos meses de dezembro e janeiro. Ele acusa o secretario Reynaldo de Barros de ter suspendido os pagamentos como forma de retaliacio contral as limimares que a Spli¿e recebea cin deremhro. wependendo a licilaçán para a co. lela de lixo domichlar e hospualar

A assessoria de Barros informou que os pagamentos foram suspenws temporariamente porque a empresal pasia por uma tiscallizaçar mas fia foram liberados (LHA) 


\section{SP recicla apenas $0,06 \%$ do lixo produrido}

\section{DANIEL CASTRO}

Da Reporagem Local

Apenas $0.06 \%$ das $13.5 \mathrm{mil} 10$. nelaklas de lixo nroduzidas diaria. mente cm Sino Paulo saio recicladas (reutilizadas) pela prefeitura

Seceundo o Departamento de Limpexa Urbanat. ollo toncladas u= lixo sāo lcrados por dia pura. o Centro de Triasem. em Pimheiros (zonn ocsic). No local. o material (viden, papel. mctivis c plastico) separado é vondido para cmpresas.

O lixo reciclia -1 ć recollhido atsavćs da colcta seletiva. Nesse sistema. a populacia sepira o lixo e depesila em comeineres cepalha. dos em Incais núblicos.

Durante undo a mes de marese. a

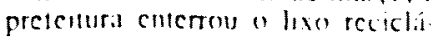
vel. A coleta seletwa era ferta, mas o material levado para o centro de triagem cra transpoitado para um atero santiano e'm f'erus. A Folha Magrus a operaçä́o.

A recriatero d: lien por prefei. turas no pias e fratticimente insignulicance. (irande pare do lixo reaclivel vem da coletit mormal. feita por coutuderes de pipel. per cxemplo. Nio ha estatisticas sobre csse mercado em Sĩo Paulo.

Sequndo a Plastivida fossociacaic) de empresas de reciclagem de plastico). $2(11) \mathrm{mil}$ encladas de plístice sion ecciclidas por ano no Brasil. bese numero equivale and xo recicliacl que a Fiefenura de Sine Piulo. recolliendo 8 entala.

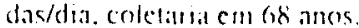

A masor parte do hxo paulistamo 191.23 -erera de 12.1 mil mone

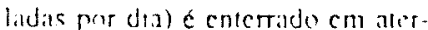

tos sambitirins. A tradição de cnterrar lixo. dém caucar danos an meco ambience. estii trarcndo prohemas a administaça publica.

Hove his so dow aterens samiti. rios en operasion na cidade. Sesumble ar tecneres at ciplacidate

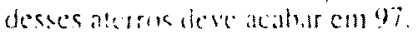

A prelentias encomera diliculdades coll crar rouss ateros. Em 93.

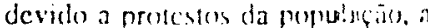
prefeiturat desictiu de moplatizer acerese cm Vila Alherira (rena norte) e latmea (zoma vil) Atalmene. cetuda ce a crasion de jum aterro $\mathrm{cm}$ leaquera (zona leste).

lara subelituir ons aterroc. a prefoilurat aprusta mon incincraderes. A comsuncind de deris deles cont ca. mendace para som loncladas/dia. esta sendalicituda. 


\section{Moradores protestam contra usina de lixo}

Da FT

Moradores da regiáo de Perus anoma nor(e) fizeram ontem pelat manhj uma manitestaçào contra a inctalaçăo de uma usina de compostagem rque transtormat o lixo em adubol e un incmerador taparelho que queima o lixo náo-organicol no parque tnhanguera

A construcion da usina de procesamento de lixo provavelmente val começar no limal deste ano. de acordo com a Secretaria Municipal do Verde.

O secretario municipal do Verde e Meio Ambiente. Werner Zulaut. 57. afirma que a instalação da usina e do incinerador não afetará de torma alguma a área do parque Anhanguerit.

"Eles vio trazer o lixio para ca porque aqui é o bairro mais pobre de Sũo Paulo". diz Preciosal Costa da Silva. moradora de Perus.

O parque Anhangueta tem y quilimetros yuadrados. segundo a sua admmistraçăo. () espaço e usado pela populaçán como area de lazer e prática de esportes. Cerca de 150) moradores da revián participaram do pro. testo de onlem.

O secretario municipal Werner Zulaut disse que a teconologia e avancada e nio permite a vazamentio de residuos e nem ndores, " (1) moradores näo precisam se preocupar porque nio havera lixo expos$10 "$. alirmou

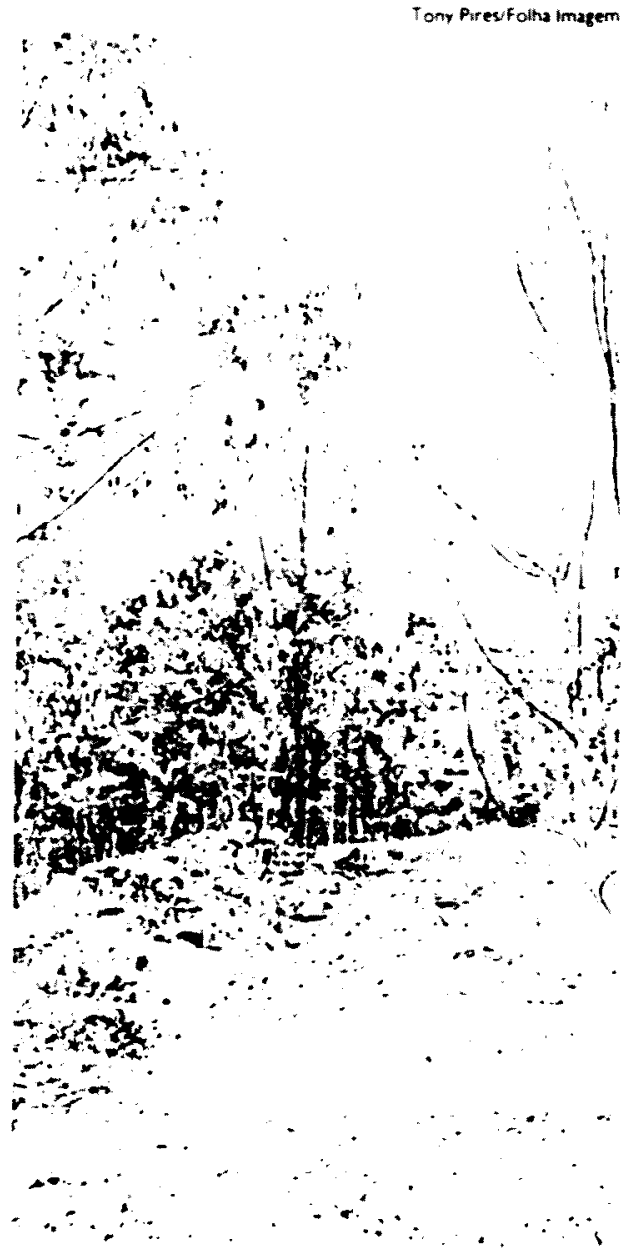

Parque onde será instalada a usina 


\section{Cidade importa incinerador de lixo}

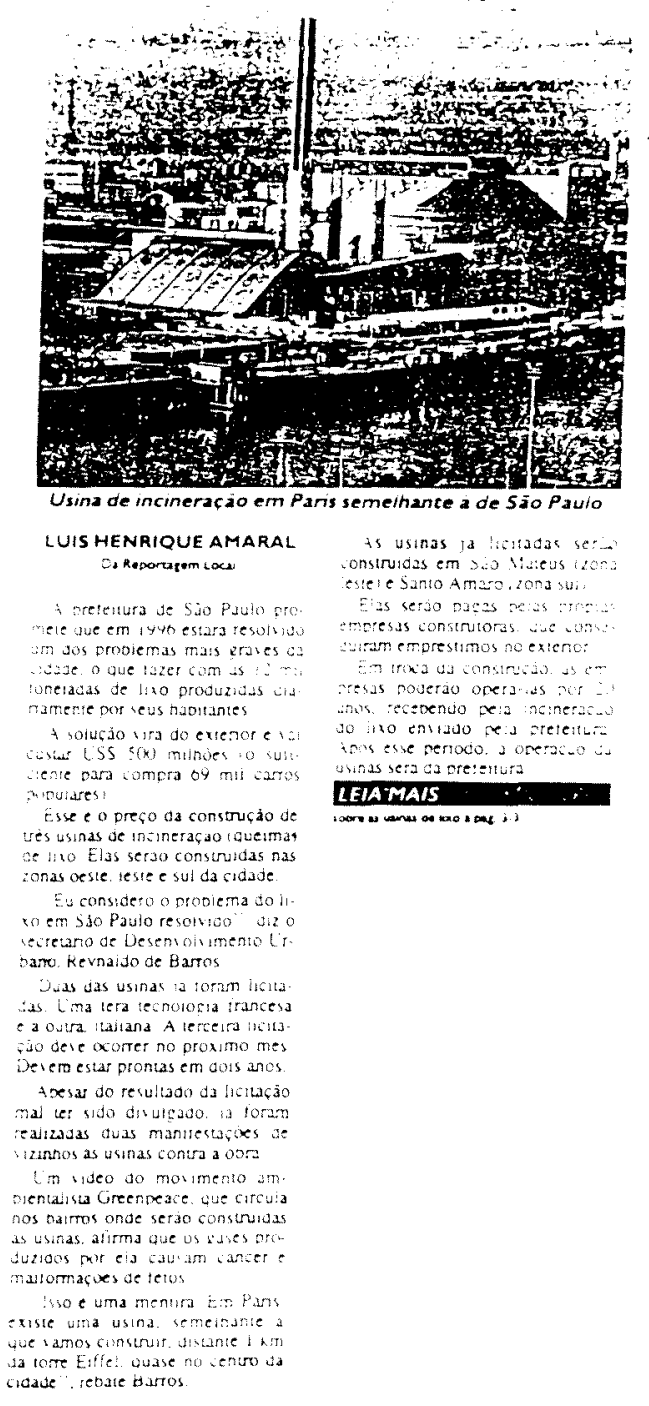




\section{Ambientalistas apontam risco de câncer}

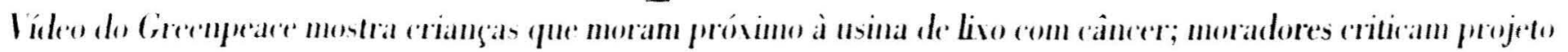
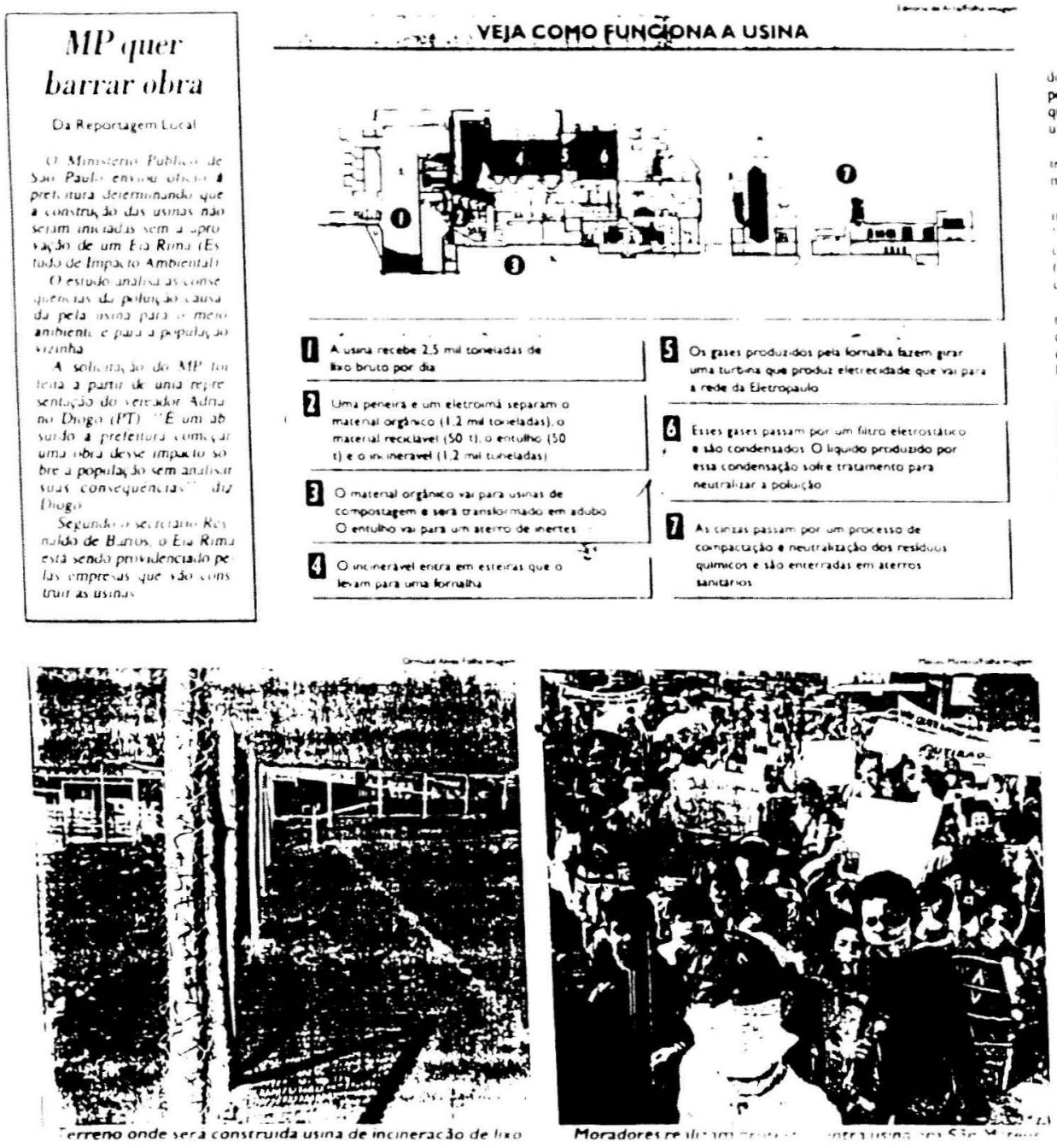
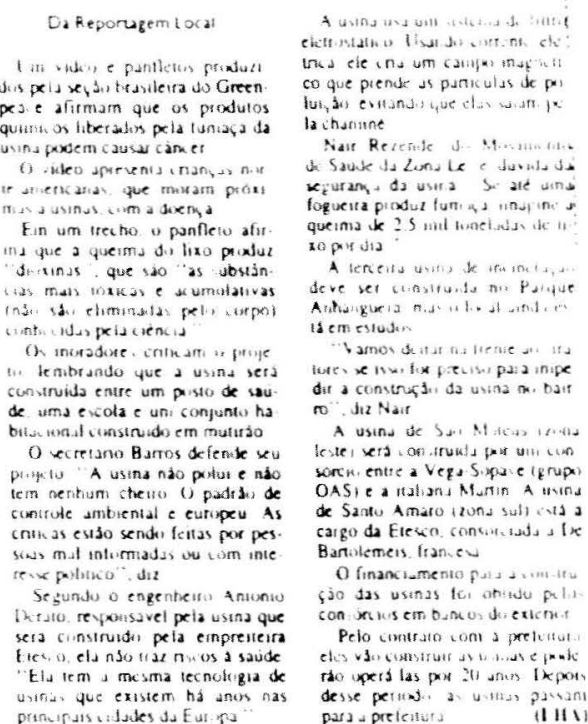

Usinas ocuparão antiga fálırica

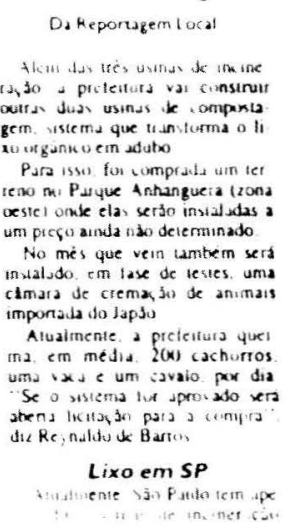

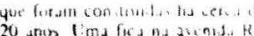

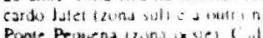

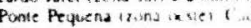

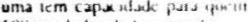

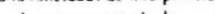

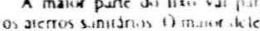
to Sao losio na rana kesic cunlinuas a reietre a quansid it de lixuatual suacajondade es gotara em dows arus

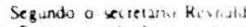
de Barros. a solukjo nasis har

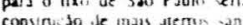
nos

necessurias por qu

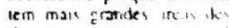
das pats consirair at.erin mas 6 lieria 


\section{SÃO MATEUS}

Maturu Maveroufoiha imagem

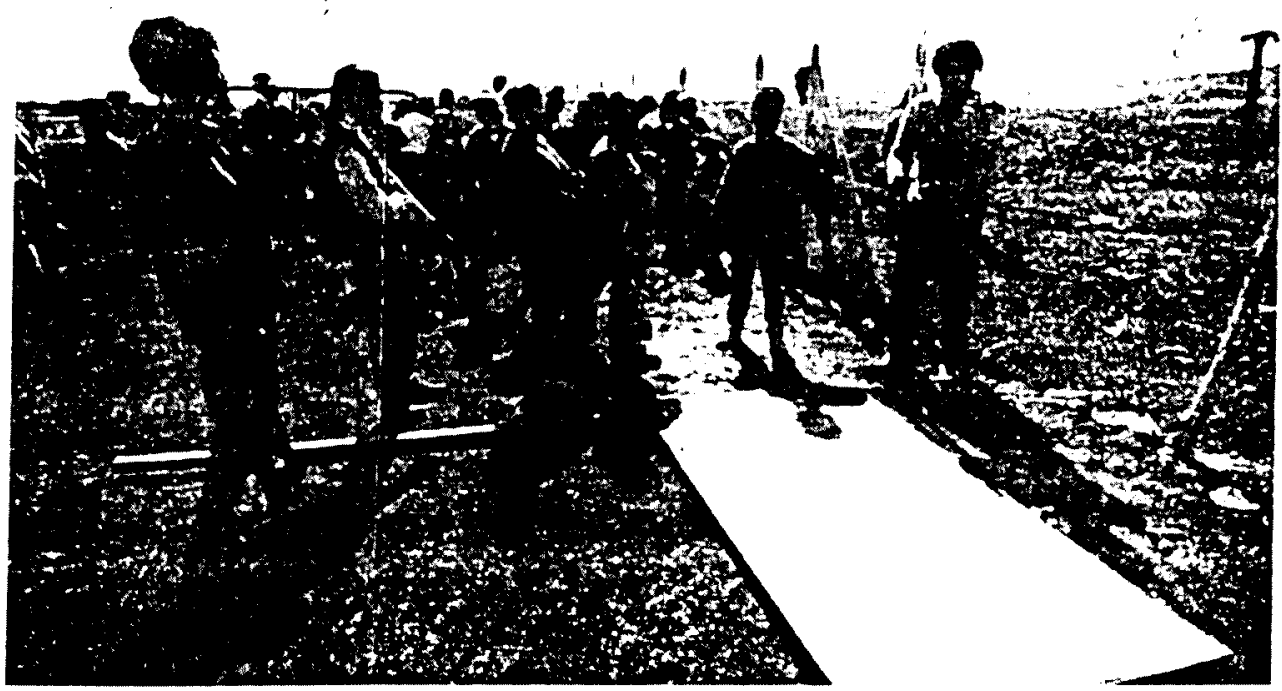

Moradoregem protesto contra construção de usina de incineracão de lixo Protesto reúne 1.500 contra construção de usina de lixo

Da Reportagem Local

Cerca de 1.500 moradores da regia de São Mateus realizaram cntem protesto contra a construça de uma usina de incineração de lixo da prefeituratio bairto.

Segundo os moradores, as usinas produzirão gases tóxicos, que causam câncer. doenças respiratorias e problemas em tetos.A usina sera construida em um terreno da prefeitura que fica ao lado de uma escola pública e de um posto de saúde. que ainda náo foi inaugurado.

Durante a manifestaça. houve orações e cancōes religiosas. "Não foi um protesto. mas um ato a favor da vida". disse Nair Rezende. do Movimento de Saúde da Zona Leste.

Os manifestantes invadiram o terreno da prefeitura, que já passou por uma terrapla

nagem para iniciar a construça da usina. Crianças do grupo escolar vizinho ao terreno plantaram arvores no local.

A prefeitura afirma que a usina. que custará US\$ 250 milhōes, não polui e não causa dano a saúde. Ainda segundo a prefeitura. a usina segue o "padrão europeu" de controle ambiental. Ela exemplifica lembrando que existe uma usina semethante a que sera construida em São Paulo na regiāo central de Paris (França). 


\section{Prefeitura será 'avalista de coletora de lixo \\ Câmara aprova projeto de lei que obriga o governo a assumir empréstimos bancários das emprcitciras}

\section{Da Reportagem Loca}

A Camara Municioal de Sio Paulo aprovou anieoniem as $23 \mathrm{~h}$ projeto de lei que laz da preteltura "avalista" de empresas de coleta : destinacio final de tixo que precisarem de emprestumos bancarios no Brasil ou extenor.

Segundo o projeto. a prefeitura terá que assumir dividas das empreiteiras.

A garantia será arraves da vinculação das receitas da taxa de limpe za ao pagamento das empretteira que fazem a colet do ino.

A taxa de limperis : cobrada ma canela do IPTV! I Imporlo Predial c Territonal Crbanos d: lodos propnetanos de imoves

O dinherro d.1 uxa $\because \therefore$ imnez. fica "carmbado an eneric das empretteras. E cssa a garancia que as empresas de colcta podera oferecer acs bancos quanuo ped. rem emprestumos.

O secretano Je finanas. Celso Pitta. disse que a garanola sena possivel com it aeenlita le ums conta corrente vincuis. 12

A conta cortert? , r ecerra dinheiro dut ax:- wi an: ad e or pagamentos . L'a dinnciro dessu conta so cucienara a feltos Dara

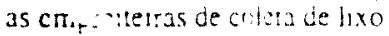

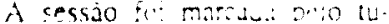

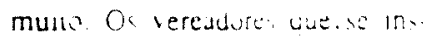
creveran, Dais lagt nic foram a tonzados. contome seemma regimento interno d. ............

Por esta razjo o l' $P C$ do $B$ decidiram entrar on:en

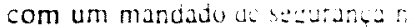

Tribunal de Justica solicitando a cancelameno da sessäo.

to reosdo fol iuntado notas a quicrancas da sessao. Nelas o pre stdente da Camara. Micuei Colas suono. autonza o vereador Amaldo Madera a se pronunciar. Mas. em seguida. sem que Madera tajasse. a votaçào e realizada.

\section{Lixo}

Pitla atima nais ver "nenhum problema no projeto" "E só uma forma de facilitar a operacio de empresumo", disse o secretario.

Ainda secundo elc. a garantia senima para facilitar a aberura de crédito para as conpreterras de lixo cue wio consirut con Sio Pato ties incineracores.

i preleltura chesa a recolner

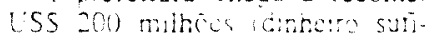
cente para constrmi to mil casas populares: com taxas de hmpeza por ano.

Antcontem. cerca de $1.500 \mathrm{mo}$ radores da regrao de Sao Mateus reatzaram um protesto contra construça da ustna ce meincracjo de lixo va pretellura no banto.

\section{Scivando es moradores as usi- ras vir arocinir gases inxicos du

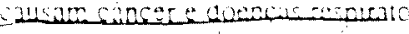

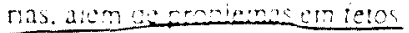

A usina sc:a construca em um cteno cha dofrentura oue lica ao ha so do una escose nutica e so un rovo lin sauce whe ancia riso for magurado

A preientura alinna que a usina une custa LSS 250 milhèes. nác cotul c nuv causa dano a saude. 


\section{Estudo condena incinerador}

Próryuisa dos Estados Unidos diz que usina para lixo pode causar câncer

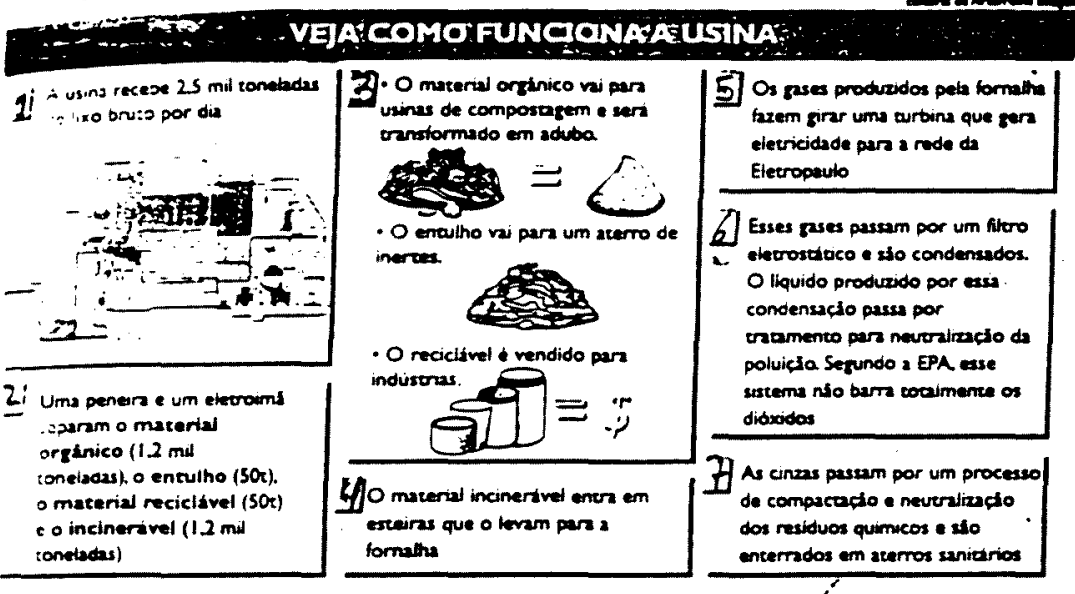

LUIS HENRIQUE AMARAL De heportem Leol

Estudo divulgado esta semana pela agéncia do governo dos EUA responstuel pela proteç3o a meio- ambiente afirma que incineradores de lixo produzem gases que podem causar cincer.

A Prefeinur de Slo Paulo estr comprando trits incineredores. que devem estar funcionando $\mathrm{em} 1996$. A pesquisa - de 2.000 paginas. apresenkada anteontem em Washington- diz que existem "evidéncies fortissimas" de que as dioxinas (substancies tóxicas promas no aparelbo imunologico.

A prefeirura afirme que as usinas sto seguras e sto modelos identicos as usados em Paris e Londres atualmerie.

\section{LEIA MAIS}

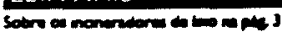

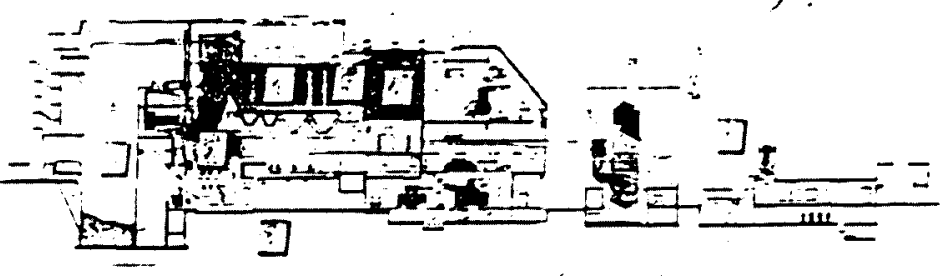

\section{Cada usina vai custar US $\$ 150 \mathrm{mi}$ à prefeitura}

D. Reporagem Local

V.. ties usinas de incineracto * wo oue devem ser construides tin Paulo. duas já form licisa. b lina fica em 510 Mateus $120-$ 4...ile e a outra proxima so ater-. Sinto Amaro (zona sul).

E... 130 queimar juntas $2.4 \mathrm{mil}$ $\therefore$ ins de lixo. Je um total de -duzidas dianamente.

$\rightarrow$ de Santo Amaro sera Rivis nor um anneircio for Wu. neia empretiera Elesco e pe mpress irancesa D: Basiolo- meis. A outra usina será construida pela Vega-Sopave (gupo OAS) ec pela italiana Marion

A terceira usina deve ser construida no Parque Anhanguera (20na oeste).

Cada usina está orcada em USS 150 milhoses. O financiamento foi obtido pelos consórcios em bancos do exterior. A garantia do financia. mento $t$ dado pela prefeitura ara. vés da caxa de limpeza urbans.

As empresas vao construir As empresas vao constrit 25
usinas e poderso opera-las por 20 usinas. Depois desse periodo. as usianos. Depols desse periodo.
nas passam para a prefeitura.
As dioxinas săo produzidas principaimente pela queima de produtos que contem cloro. como o plástico e o papel.

No corneço do ano. o governo none-americano proibiu a realiza. nŏ̌o de licitaçes par a construçăo de novos incineradores de lixo ate que seu órgảo de defesa do meio ambiente complete o esrudo sobre as dioxinas.

Após sua publicaço. o estudo sers debauido com cientisias e re. sera debaudo com cientisias e resultado final será divulgado $\mathrm{em} 95$. 


\section{Teste em cobaias comprova risco à saúde}

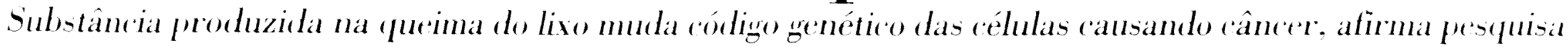

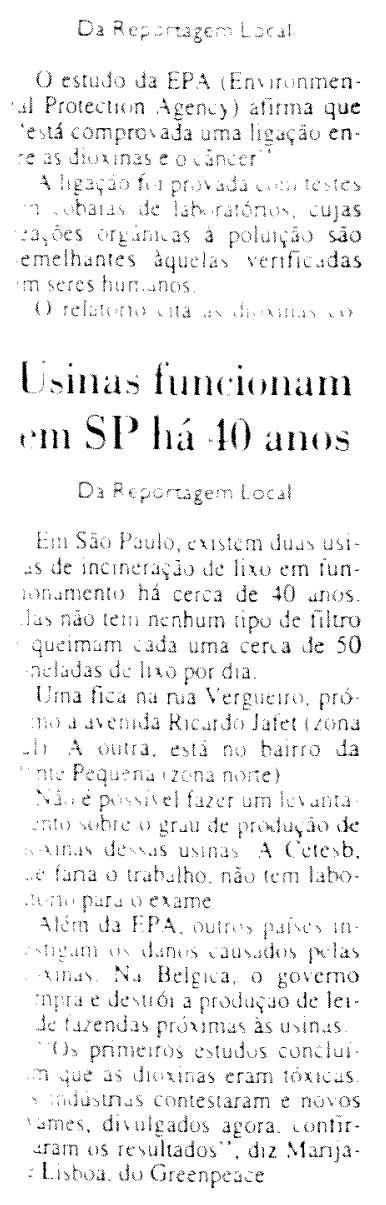

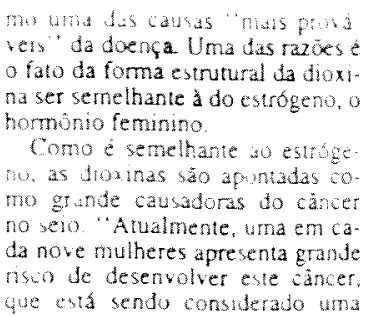
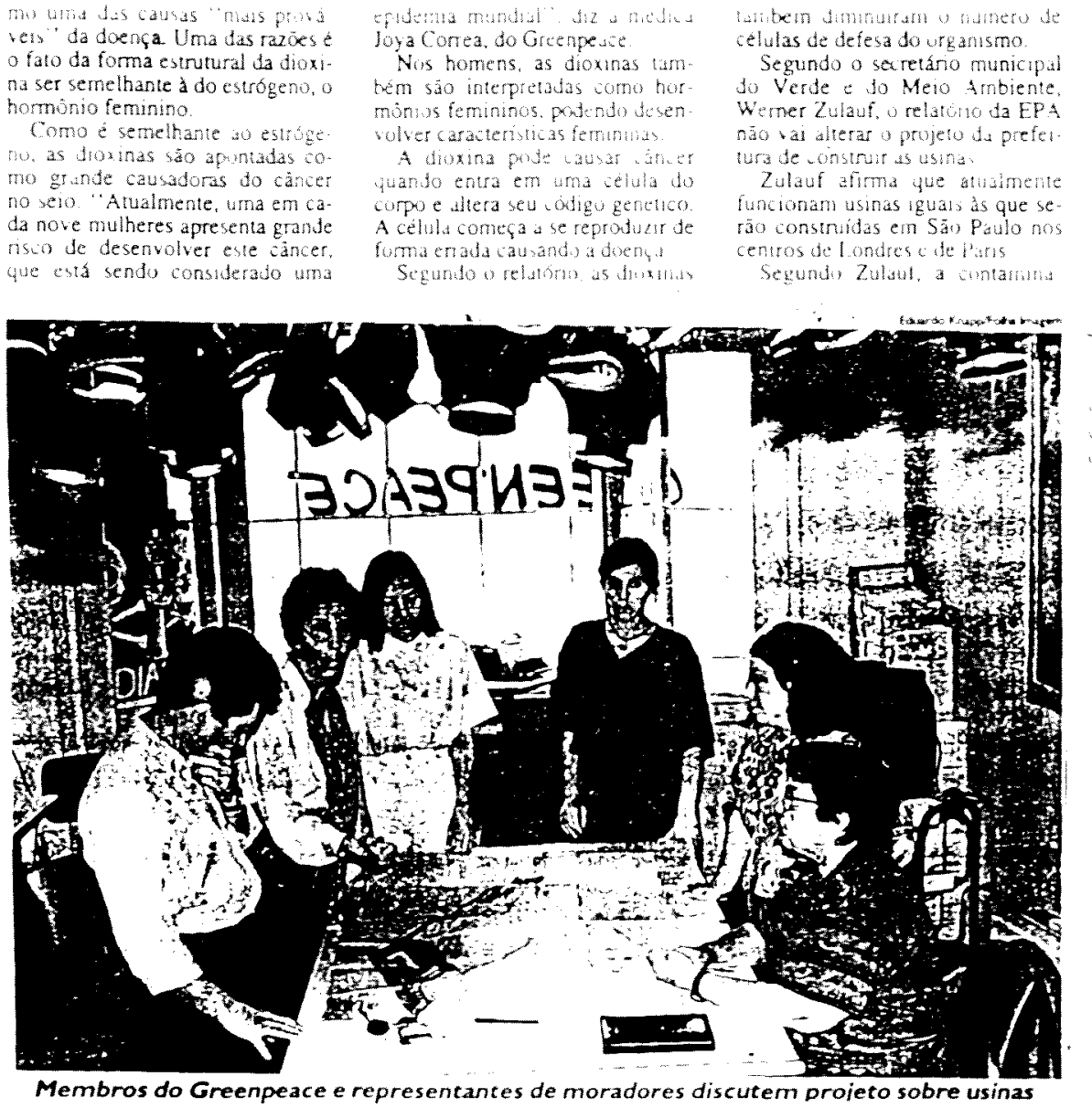

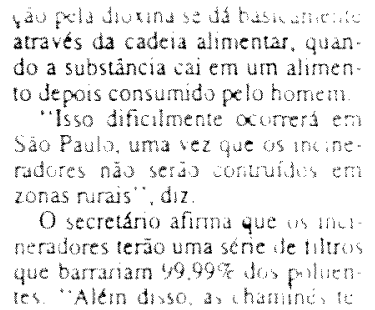

GLOSSÁRIO

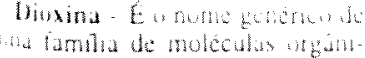

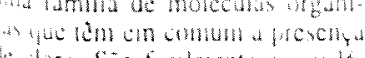

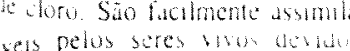
vers petos seres propredades twidingumas que tentes no metabohsmo unmal vegetal As alividades yü neces un de reaçes com cloru produ zem diuxinas Entre clis. chtäo ineneraçuo de lixu eni usmas. 1 bricą̧̃ de herbicidar : conserva so de madeira, por excmplo Greenpeace - Eamalsonhico da entudade ambientihis do mun da. Tem escritónos em 22 punsos No Brasal, foi criada duante ECO 92 e reune 3.504 memb

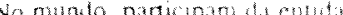
45 milhoes de pessoas

EPA - E un orguo federal dus Celesb. Estabelecer poline pub cas sobre questões ligad us a colo guas decisoes servem como onemação para outros paises devido ao seu grau de respeitabulidade.

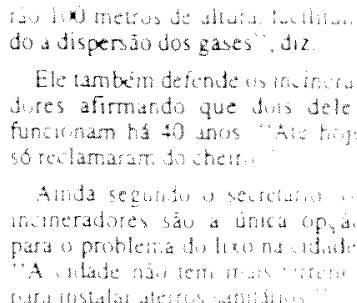

furciniscalat at

Filtro elatrostatica f fllm yo será instulado nas usinas da profer rura E considerado un do siste mas mus eficazes fara impuill

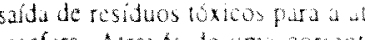
mostera Alraves de una concone elétrica, forma un campo mugnét co que retén as punticulas. Usina de compostagem ganco cono restos de conula em asubo. A prefercurs ploneg 24 (o) tonclidas de lixo por da Aterro de incrtes

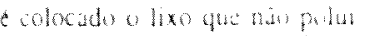

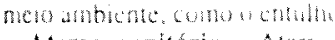
Alerro samitario - Alem yo cecabe to hupor pojadu coberto nor rerra k.

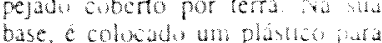

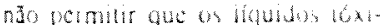

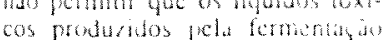

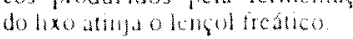


ADMINISTRAÇÃO

\section{O lixo em}

São Paulo

PAULO PLANET BUARQUE

São Paulo recolhe $15 \mathrm{mil}$ to. neladas de lixo por dia. E até a presente data. o destino final desse lixo são aterros sanitários e. em pequena quantidade. inci. neração rudimentar. que trans. forma o resíduo em adubo.

Os aterros sanitários rema. nescem distantes e invariavel. mente combatidos pela popula. ção vizinha. Mesmo quando convenientemente cuidados. como é o caso do Sảo João. o mais novo deles.

Desde os anos 60. a Europa trata o destino final do lixo atra. vés de incineradores ultramodernos, com poluifão zero e edifícios modernos, que nada indicam tratarem-se de obras sanitárias. Milão. por exemplo. tem toda a sua iluminação pú. blica e o seu transporte de su. perfície acionado pela energia produzida por um incinerador.

Recentemente, e em boa ho. ra. a Prefeitura de São Paulo li. citou e contratou com a Eresco e a OAS. associadas a grupos italianos (De Bartolomeis) franceses $(G D F)$. a construção ef a operaçáo de dois incineradores. com capacidade para 2.50n toneladas/dia. cada um produ. zindo energia suficiente para. iluminar toda São Paulo. Inicia. ¿iva merecedora de encômios.
Dentro de dois a três anos. no máximo, teremos essas usi. nas em operaçào. mercê do fi. nanciamento total das referidas obras por parte dessas empre. sas, ressarcidas do investimento mediante o pagamento do lixo ali incinerado.

Visitamos as usinas de Paris. Londres. Milão e Pizza e pude. mos constatar que. infelizmen te. estamos atrasados 30 anos. no mínimo. na forma como conduzimos o processo do lixo.

Usinas modernissimas. com controle absoluto e extrema mente eficientes e eficazes, em bora operadas por computado. res e. portanto. com pouquissi. mos profissionals. $O$ dia em que São Paulo as tiver em funciona. mento. verá a população. mesmo a bem próxima lo de Paris está a $5 \mathrm{~km}$ do Arco do Triunfol. que estaremos. por fim. ingressando efetivamente no Primeiro Mundo nessa área.

As usinas contratadas, po. rém. não são suticientes. Outras duas. ou três. são necessárias. Como as usinas de composta. gem e o adequado tratamento do lixo hospitalar. nos mesmos incineradores. O primeiro passo foi dado. Outros se impóem. ra. pidamente.

paulo planet buarque. 66. bacharet em direto pela Pontificia Universidade Catolica de Sào Paulo (PUC.SP). e presidente do Tribunal de Concas do Municipro de Sio Pauto. 
LIXO

\section{Decisão do BC atrapalha plano de incineração da prefeitura}

LUIS HENRIQUE AMARAL

Da Reporragem Local

O Banco Central negou autorização para o Banespa intermediar o empréstimo externo de US\$500 milhões para a construção de duas usinas de incineraçào de lixo em Sðo Paulo.

A decisão, tomada na segundafeira, compromete os planos da prefeitura de, $\mathrm{em}$ dois anos, incinerar metade das 12 mil toneladas de lixo que sảo produzidas diariamente na capital.

Os empréstimos foram solicitados a bancos estrangeiros pelos dois consórcios que venceram a concorrência para a construçăo das usinas, que sảo encabeçados pelas empresas Vega e Etesco.

Pelo contrato, as empresas vảo construir as usinas com recursos próprios, mas poderão operá-las por 20 anos, queimando o lixo entregue pela prefeitura.

Para facilitar a obtenção do empréstimo por parte das empresas. a prefcitura aprovou na Câmara uma lei que coloca a taxa de lixo cobrada no IPTU como garanta ao empréstimo durante 20 anos. Ou seja. a prefeitura se tomou avalista das empresas.

Essa lei serve como garantia para os bancos estrangeiros de que receberão o pagamento do emprés timo feito para as empresas parti. culares. Se elas nāo pagarem, a prefeitura pagará.

O Banco Central considerou que essa lei fere o artigo 25 da resolução número 11 do Senado, que dispóe sobre as operaçōes de crédito interno e externo dos Estados e Municípios.

$O$ artigo diz que é vedado aos municípios "assumir compromissos diretamente com fornecedores. prestadores de serviços ou empreiteiras de obras, mediante emissão ou aval de promissórias, aceitação de duplicatas ou outras operaçöes similares".

A decisão do $\mathrm{BC}$ lambém levou em conta o artigo $7^{\circ}$ da resolução 2.008 .

Ele proibe que os bancos acoIham "qualquer modalidade de empréstimo" que tenha como ga- rantia direta ou acessoria "notas promissorias. duplicalas, le as de cambio ou outros títulos da especje. de responsabilidade direta ou indireta do setor publico"

Além disso. a decisão do $\mathrm{BC}$ cila o artigo primeiro da resolução 2.008 do proprio banco, que limita 3 obtenção de empréstimos por parte de instiluiçōes financeiras feitos para Estados ou municípios.

O Banespa já teria extrapolado seu limic, o que inviabilizou que intermediasse o empréstimo.

O secretário das Finanças, Celso Pitta. disse ontem que a decisão do $B C$ diz respeito apenas ao banco que vai intermediar o empréstin:

"As cmpresas podem solicitar outro banco para que acolia o es préstimo."

Para o vereador Adriano Diogo (PT), que enviou oficio ao $B C$ afirmando que o empréstimo era irregular, a prefeitura nāo poderia usar a laxa do lixo como aval do $\mathrm{em}$ préstimo. "Eles estāo usando um recursos público para garantir um empréstimo que sera usado por empresas privadas."

Ontem tamberm o Senado autori zou a prefeitura a emitir R\$606.5 milhões em Letras do Tesouro $\mathrm{Mu}$ nicipal. Os títulos devem ser utilizados para o pagamento de desapropriaçōes pendentes. 


\section{Zulauf defende usina que antes atacava}

\section{LUIS HENRIQUE AMARAL Oa Reporzagem Local}

A opinião do secretano munici. pal do Verde e do Nero Ambiente. Wemer Zulauf. sobre as usmas de incineraçào de lixo que a prefeitu ra pretende instalar em Sáo Paulo mudou radicalmente em menos do dez anos. Hoje. Zulauf é um dos principais defensores do projeto

Em 1986, quando era presidente da Celesb (Companhia Estadual de Tecnologia Ambiental). ele travou uma guerra contra a instalação de usinas defendida pelo entäo prefeito Janio Quadros.

Zulauf deu entrevistas e escre veu anigos dizendo que os gases produzidos causavam cáncer.

Em anigo publicado na Folha no dia 16 de selembro de 1987. Zulauf escreveu:

"Usinas de incineraçăo de lixo urbano são instalaçóes de alto potencial poluidor, fontes de cinzas volantes que carregam a dioxina para a atmostera. Esse composto químico. nào biodegradavel. é extremamente persisiente e figura como a mais róxica das substancias conhecidas."

Cerca de um ano antes. em 9 de outubro de 86. Zulauf disse em entrevista à Folha que as usinas de incineraçào "liberam elementos altamenie cancerigenos"

Em setembro deste ano, ja como secretáro municipal. Zulaut afirmou que o incinerador e a unica opçăo para o lixo da cidade. e apresentou outra teona sobre o seu potencial cancengeno:

"A contaminaça pela dioxina se dá basicamente atraves da cadeia alimentar, quando a substáncia cal em um slimento que será depois consumido pelo homem. Is. so dificilmente ocorterá em Sãu Paulo. uma vez que os incinerado. res nào serão construidos $\mathrm{em} 20$. nas rurals". disse.

$\mathrm{Na}$ mesma entrevista. do ser perguntado sobre os incineradores que ja funcionam na cidade. o secretario do Verde e do Melo Ambiente disse que "ate hoje so reclamaram do cheiro deles"

No arugo de 87. Zulauf alinhavava questões que hoje sào ban. deiras dos movimentos que se opõem ao projeto de Maluf.

"A lei estadual n. 1.817/78. que disciplina o zoneamento indusirial. impỏe que usinas incineradoras e compostadoras, citadas nominaimente. nào podem ser insialadas na Grande São Paulo por se. rem alividades somente compativeis com zonals de uso es. tritamente industrial (ZEI). que deliberadamente não foram criadas nessa região para a proteção do já saturado meto ambiente metropolttano." As usinas que a prefeirura quer instalar na cidade ficam $\mathrm{cm}$ Santo Amaro e em São Mateus. ambas na regiào metropolitana.

Zulauf atribui suas declaraçoes contra os incineradores io clima de "guerra" que maninha com o preteito Janio Quadros.

-O entajo prefeito se recusava terminantemente a fazer o licen cramento ambiental das usimas. $\mathrm{Na}$ epoca. a fiscalizaça ena de res. ponsabilidade da celesb. de onde eu era presidente ". Jlirma

Zulaut diz seu artigo publicado na Folha fol um "discurso de guerra" e que. na época. já achava -fundamental que São Paulo 11. vesse seus incineradores. Pors a possibilidade de construir atertos santrarios estava se esgotando

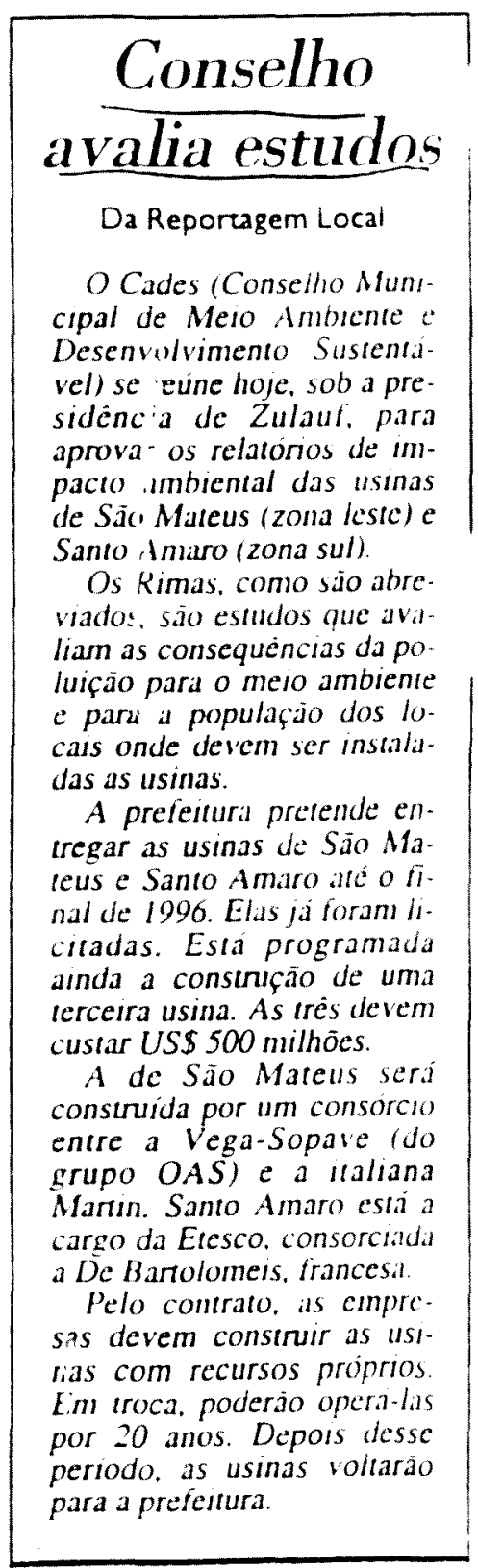




\section{OPINIÃO}

\section{A reciclagem de lixo WERNER ZULAUF}

O colapso do sistema de destino final de lixo de Sảo Paulo é imi. nente. $O$ aterro sanitário de Santo Amaro (Interlagos) pode desabar a qualquer momento, obstruindo o canal do rio Pinheiros ou sotemando a fertovia da Fepasa. O aremo de Vila Alberina (Cantareira), se desabar, pode sorerrar duas indústrias e várias casas. $O$ aterro de Bandeirantes (Perus) já desabou uma vez matando um operáno e paderá ser objeto de novos aciden. tes.

As emissóes de gases e líquidos oercolados (chorume) dos aterros constituem problemas ambientass graves, afelando a saude das populaçóes vizinhas. Os incineradores -xistentes (dois) sajo velhos e tec nologicamente superados, já que najo possuem nem filltros nem lava. dores de gases da combustao. As usinas de compostagem (duas) são tamberm obsoletas do ponto de vis. la tecnológico, gerando sérios in comodos (mau cheiro) à populaçáo vizinha.

Este é o cenário en que se deu a decisáo para resolver o mais grave problema ambienial de Sáo Paulo

A soluçāo é suprapanidána. jó que se baseia em diretrizes forma. lizadas pela prefeita Luiza Enmdina, e está sendo implementada pelo prefeito Paulo Maluf. Ale o saudoso prefeito Jose Carlos de Fi. gueiredo Ferraz deu uma valiosa contribuiçaá: a viabilidade do $\mathrm{cm}$. preendimento. mediante concessảo à iniciativa privada, decorre da Lei 7.85273 de sua iniciativa.

A solução adotada para o lixo seco e a mass moderna do mundo. já que permire a reciclagem de todos os maleriais para os quais haja mercado, incinerando-se o restan. te, com reaproveitamento de energla tenno-elétrica.

A fraço amida (lixo oreanico) sera reciclada em brogas ienergia de biomassil) e composto organi. co, ferilizante agricola.

$O$ inontanie dos investimentos, do mais completo stsiema de ma croreciclagem do mundo, será da ordem de 600 milhoes de dolares. todos investidos pela inicialiva privada. A prefeilura pagara por tonelada de lixo processado.

A populaçào lambém será chamada, no momento oportuno. dar a sua contribuiçäo, separando o lixo doméstico $\mathrm{cm}$ duas fraçōes. o lixo úmido (orgánico) será acondicionado $\mathrm{em}$ um recipiente e lodo o restante (lixo seco) o será em outro. A entrega. para a coleta. será simuliadea (nào haverá colela dife. renciada para um ou outro lixo) e os caminhóes coletores terjo dois compartimentos, um para cada ij. po de lixo.

Por firm, todas as instalações passarn por um crivo de licencia. mento ambiental, promovido pela Secretaria Municipal do Verde e do Meio Ambiente (SVMA) e pelo Conselho Municipal do Meio Am. biente e Desenvolvimento Susten ravel (CADES), que exigem os mais rigorosos parántetros de con. irole ambiental do numido.

\section{WERNER E. ZULAUF. 58 . engmmeno (m)

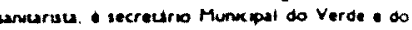
Mero Amberente de Sto Pouto. 


\section{Especialista faz crítica} a incineradores de lixo

Paul Caneti. especialista norte-americano em incineração de lixo, fez palestra ontem na Câma. ra Municipal de Sảo Paulo. Ele criticou a projeto da prefeitura de inslalar dois incineradores de lixo na cidade. Canett esta no Brasil a convite do Greenpeace. 


\section{PROJETO DE LIXO IRREGULAR \\ Gás de incineração pode causar câncer}

Da Reportagem Local

Reliturio do EPA (Envirommental Protection Agency, agência norte-americana responsável pela proteçào do meio ambiente). divulgado no ano passado. constatou que on gases que saem dos incineradores causam cancer

Segundo o relatório, "está comprovada a ligação entre dioxinas e câncer" Dioxinas sāo elementos toxicos que se formam quando ha incineração de produtos químicos principalmente os que têm cloro.

A teoria foi comprovada em testes com cobaias, que têm reações orgânicas à poluição semelhantes as dos seres humanos.

A Faculdade de Medicina da USP chegou à mesma conclusão do EPA: gatses produzidos na incineração causam câncer

Segundo o diretor do Depanta- mento de L impeza Lrbana. Paulo Machado, o incinerador que poderá ser usado na área que está sendo desapropriada tem sistema de filtragem que permite a propagaçá de indices menores yue 0.14 nanogramas $\left(10^{4}\right)$ de dioxinas por tonelada de lixo incinerado. "São incineradores modernos que não catusam cancer" dic Machado.

A prefeitura vai instalar tres in cineradores em Sào Paulo. Cada
III) bal cuslat cerca de liss 150 milhoes e lerá capacidade de que mar l.2 lonelada de lixo por dá.

Dols desses incineradores ja foram licitados: a de Santo Amaro (zona sul) e o de Sapopembat lana leste) Venceram as concorrincias os consorcion liderados pilan em presas Elesco (zona sul) e (OAs (Lona keske). O de Perus (ama nor

te) anda náo foi licitado

(I.uis Henrique Amaral 
inclui cotidiano

\section{Maluf quer usina ao lado de parque}

Prefeitura projeta instalação de incinerador de lixo vizinho a uma área de proteção ambiental

VICTOR AGOSTINHO Da Reportagem Local

A Prefeitura de Sāo Paulo desapropriou os primeiros $34 \mathrm{mil} \mathrm{m}^{2}$ de um total de $400 \mathrm{mil} \mathrm{m}^{2}$, entre as rodovias Anhanguera e Bandeirantes (zona nome) nerador de lixo de USS $150 \mathrm{mi}$ thines.

O local fica ao lado do parque Anhanguera, considerado área de proteçào ambiental

$O$ incinerador ainda não for comprado e nem teve a montagem aprovada pelos Conselhos Ambiente estaduale municipa

A Comissão de Meio Ambiente da OAB IOrdem dos Advogados da OAB (Ordem dos Advogados do Brasil), que visitou na última quinta-feira a área em Perus tebol - está pedindo na Justica a anulaço do ato de desapropriaca a

Femando Pinheiro Pedro, presidente da comissão justificou o pedido de unu ay̆o: Essa desapropriaça des respeita a Constituição. E preciso un estudo previo de impacto am biental que avalie a poluiçăo gera da pelo incinerador

A OAB só ficou sabendo da de sapropriaço for meio de uma nodificacáo do juiz Lino Manoel Dune Bativa Ribeiro. da $11^{\circ}$ Vara da Fazenda litica que esia ara da Fazenda putica. que esta artitrando os: da desapropra

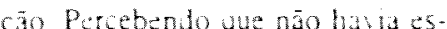
tudos de impacio ambiental na ação, o juiz avisou a entidade e o Ministério Público No local da desapropriação funciona, desde 1957 uma fábrica de sebo para sabunetes e de farinha de osso para ração, a Joào Gava e Filhos L.tda.

Trabalham na fabrica 180 funcunánios, que processam 80 toneladas de ossos borinos por dia

As sobras dos açougues são le. adas para a fábrica e cozidas em 12 caldeiras a uma temperatura de 500 C. A gordura é transformada em sebo e os ossos. em farinh

Roberto Gara. 65. dono da fa. brica. reclama da desupropnaçás do valur oferecito nela prefeitur

- Fizemos uma avaliaca e estamos pedindo RS 7.1 mithoes pela fabrica (terteno mais benfeitorias). Mas a prefeitura quer pagar R\$2.4 milhoes Com ecse dinheiro não consioo montar a fabrica ern outro lugar Se a prefeinura pagasse o que iale já seria dificil fazer a transterencia Todos os funcionários moram aqui do lado. Onde é que eu vou artumar nowa máo-de - bbra?". afimou Gava.

Ele estima que a transf." "cia de sua fábrica demorará ce

ano para ser concluida.

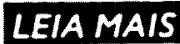

Sobre memeriores de lixo is py: 


\section{Aterros da prefeitura só têm capacidade para mais 3 anos}

Instalação de dois incineradores poderá aliviar o problema em 1997

\section{VICTOR AGOSTINHO Do theoran term}

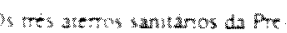

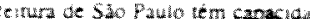
se tara esto

Vus tres anos

s. o aterro da roc la esgorar cu potenciall, comeca a acumular restador na vituma area reservada

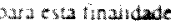

a preterura apos:a na inxwis

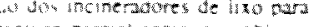

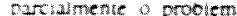

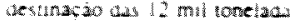

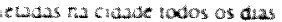
bo voluthe coltudo, 919 . parar nol ateros

Dois incineradores de hixo to fam lictados e poderắo entrar em operaça em São Mateus zona estel e em Santo Amaro tzon shi daqu a dons ou tres anos

bepors de inglaitusos os uncrie. raderes a worvida dos atemo

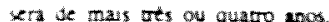
scundo Payio Gornes Mactuto sirfor do Deparamento Mumo pal de Limpeza Litane

Cua incinernots tem o custo araliado em RS 150 mulhoes. Eles poderato receber 5,000 tonelacia de lixo dianamente.

As cinzas do que for queimado. J para ser incinerado. conunuarlo a er depositavas nos tetros.

a preferun mantern ens an:

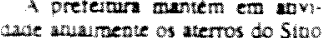

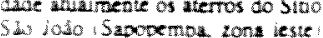

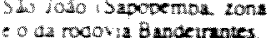
- o da rocowa bundernates. untos eles rectom 5.000 to

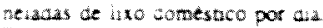

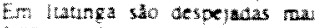
. Wo tonelacas de entuihos.

Alem oesses trés aterros, a pro cellura e oongada a dar manuten- jo a outros quarro que esulo des. vradis Mesmo depors de fech Jos or arerros conous de fech Uos or iteros conanuan prod. nommes por mass to anos

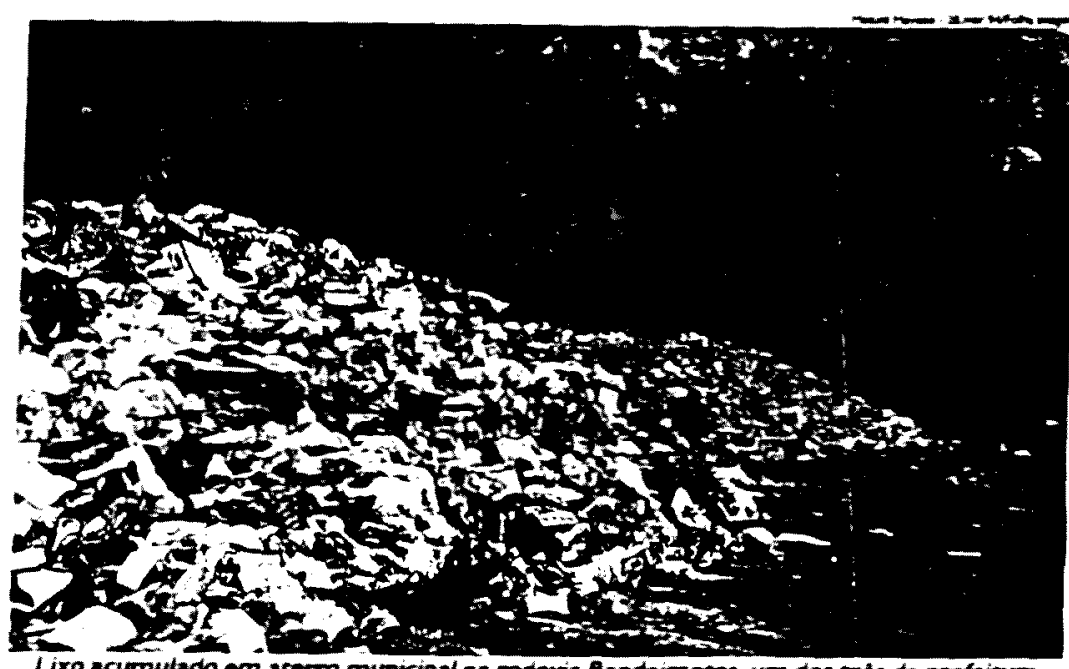

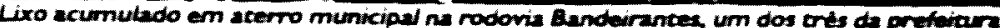

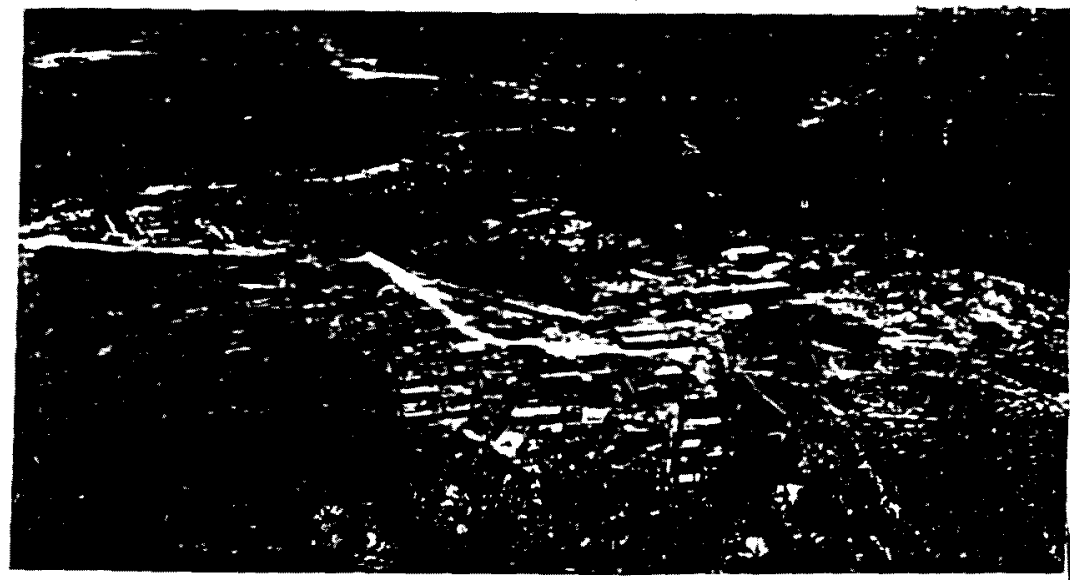

Criacio de porcos em um lixlo dandesano na zona norte de SP, vira de um helicoprero

Saúde

Empresa age na 'base do susto' Da Reporagem Loal

A Cetesb /Companha de Tec hovia de Sanearaento Amber Hi entrenta diweras dificuldado

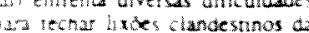

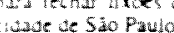

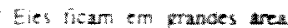

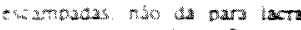

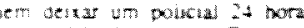

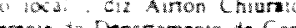

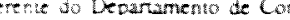
we da kegiäo Metropolitana.

steundo Churato, a empresa tratiatia na "base do susto". ten undo idenuñcar aual fix a empre a que perou o uxo e aphicanoo mulua nelas

\section{Tiro}

Pedro Penteado de Castro Neto. xerente de departanenio da $C$. texb. conta qut dase kevou un to durante a tentistiv de tectur ur un wo clandertsto ras zonal sesie da sapten.

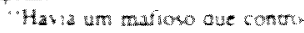

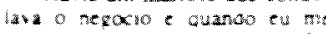

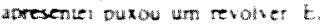
su correndo lemor

Sequndo Comurato. as haxes ax dem razer danos do mero ambien. ce guando o "chonume" o houd da termentacso do lixo organ penetra no solo e contamina olen.
coltrabro
(LHA

Porco pode causar dano mental

\section{Da Reporagen Locat}

A responsabilidade pela fiscal zaca das macóes de poros en uxes edvidida entro poverno edera trudus e mencipal

Serunio o daretor do Denart

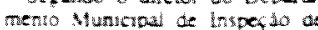
Aintwos Luy Colomo oorto nados sem condipoes at nuten

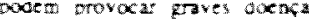

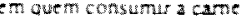

A mas tengosa e a cisucter

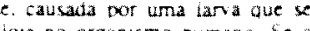
thola no organismo numano $x$ voa cera problemas neurouncos

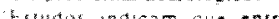

$10 \%$ e $12 \%$ das internacós ps! quiálicas sảo de pessoas com problemas mentas causados peia c15. ucercose diz Colombo

\section{Seguranca}

Para gumara a seminan de um lindo. tecensurso que sex cho sin torado cort uma mana piduted de aits demsidude com opu mulmetro de situris

Exsa mania ocve exar soore uma camada de mens metro de $v$. gila pisa evitar qut os gaves for mados pela decompusicáo do ino explodam aeve haver tubos para expla a a

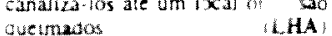




\section{GEMMISTERO}

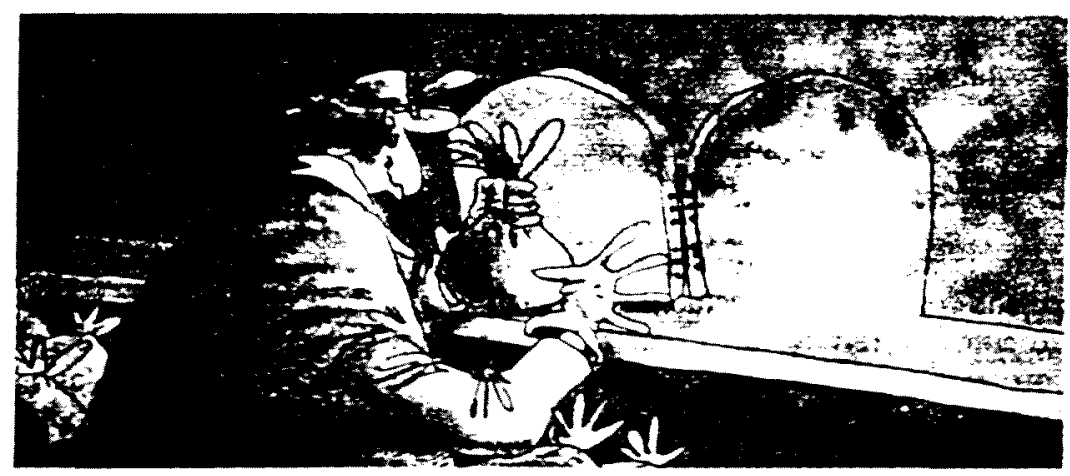

\section{0 que é incineração?}

Cláudio Domingues da Silva. 23, estudante, Itapecerica da Serra(SP)

Paulo Gomes Machado, do Departamento de Limpeza Lrbanada PMSPresponde:

"O processo de incineraço é ba. sicamente a queima de materiais em altas temperaturas (geraimente entre $850^{\circ} \mathrm{C}$ e $900^{\circ} \mathrm{C}$ com uma unantidade adecuada de ar. durante um tempopreestabelecicio.

"Anineraca atuamente bastante utlizada devdo as vantagens que apresenta, tais como reducão drástica do volume do residuo cerca de $70^{\circ}$ o a 750 , , possibilidade de queima de cualquer tipo de residuo e sua capacidade de destruica de bacterias, de virus e de compostos organicos. "A incine- racáo e usada pela Preteitura Municipal de Sáo Paulo para o tratamento dos residuos gerados em estabelecimentos prestadores de ser$\checkmark$ icos de saúde. O resultado do processo e tornar inertes os residuos. alem de reduzir seu volume peso.

"Tornados inertes, os resiuuos percem suas caracteristhas inteccosas. A escoria e as cinzas resul tantes da queima podem entao ser dispostas em aterros sanitarios.

Cortespondencla para a secao Sem Mistero deve set encamintaca a Edroria ce Cencua a Barao de Limeira. 425 . 4 andar CE $01290-900$ 5 a Palol, com nome, idade profissao ende reco. Na serao respondidas canas com pedidos de aconsehamento medro ou psicorogico 


\section{OPINIÁO}

\section{A ameaça dos residuos urbanos}

\section{ROBERTO KOCHEN}

- Asponsiga de residuos solldo urodnos "lixo' tornd se ide . 2 mus importante no testado df tu Paulo, pelos volumes gerado disriamente por nossa populacad. Em nosso pais, apenas $23 \%$ do lito culetado e tratado e disposto ade. quadamente, e 770 e disposto a leu aberto (em lixoes). de moda whamente indequado em termos in preservasa do meio ambiente

Vis muncipio de sao Paulo, sáq kerados diariamente cerca de 13 mil a $1+$ mil toneladas diarias de $k$ xo. Desse loid, aproximadamemta $2 " 0$ sao incinerados, e $0 \%$ a $7 \%$ sảo 1ratadus em usinas de composta iem. () restante e encaminhato issa disposicio inal em aterros umuanos $(910)$. A coleta seletiva recliagem sao realizadas em cered je lo da tonelagem diaria.

Enquanto no municipio de Sáo Paulo a coleta, tratamento e dispo. siça do lixo urbano encontram: equacionados. u mesmo náo ocor: re no interior do Estado. Levanta. mentos realizados por orgaos pu: hilces revelaram a keraça diana we 0.121 concladas nesses munici. mus. Wesse cotal, cerca de 3.953 to neladas $105 \%$ ) sáo dispostos em lir roes. apesar das consequencias nctastas do meto ambiente e a sau. uepublua que a praticasarreta
A decomposicho la maleria or banked thesente nos residuos solt

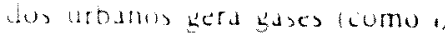
matanoco gas sultidncot, que im. pulam inelo amotente e tham risous a sude publica. Ocorre tunbern a tormaijo de horume (um liquido escuro. allamente por luentel, que se intilira no solo contaminando a agua subterraned * u proprio subsolo. A geotecnid umbiental. um dos ramos da engor ninaria. rata da disposişau de resi. Juos soludos em iondicoes ade quadas de preservadao do mete ambiente. Alerros sanilarios sag geratmente mals economicos do yue sistemas de tratamento do li. xo. como compostagem e incine. racia. E. ses aterros. se projetados. construidos e operados correch mente, coletam os gases geradós na massa de lixo em decomposiço dispersando-os na dimostera, ir queimando-os) e drenam o chorume cormado que encaminhado pura eslacoes de ifalamento). Evi ta se assim a contaminaça do so. 10. da diguac do ar

E necessario que os municipios do nosso Estado realizem o geren. - iamento de seus residuos sólidos urbanos. Us aerros santiaros /per o balxo custo de implantacáo uperacau devem ser estumulados. e seu proieto e construcao, realizalos com cruterios cientificos, em. pregando-se os conceltos de geo: tecnia amblental. Esperamos quá. assim, os lixóes citados neste arzh go sejam em breve apenas uma (iriste) memoria do passajo.

Roberto Kochan $\$ 2$ ptotessor de geotexnie

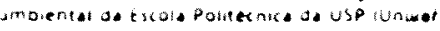

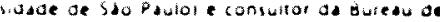
propetos 


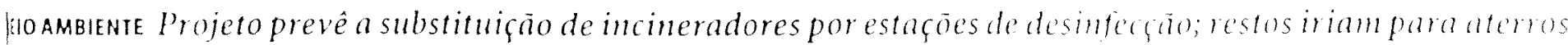

\section{lixo hospitalar pode ter novo tratamento}

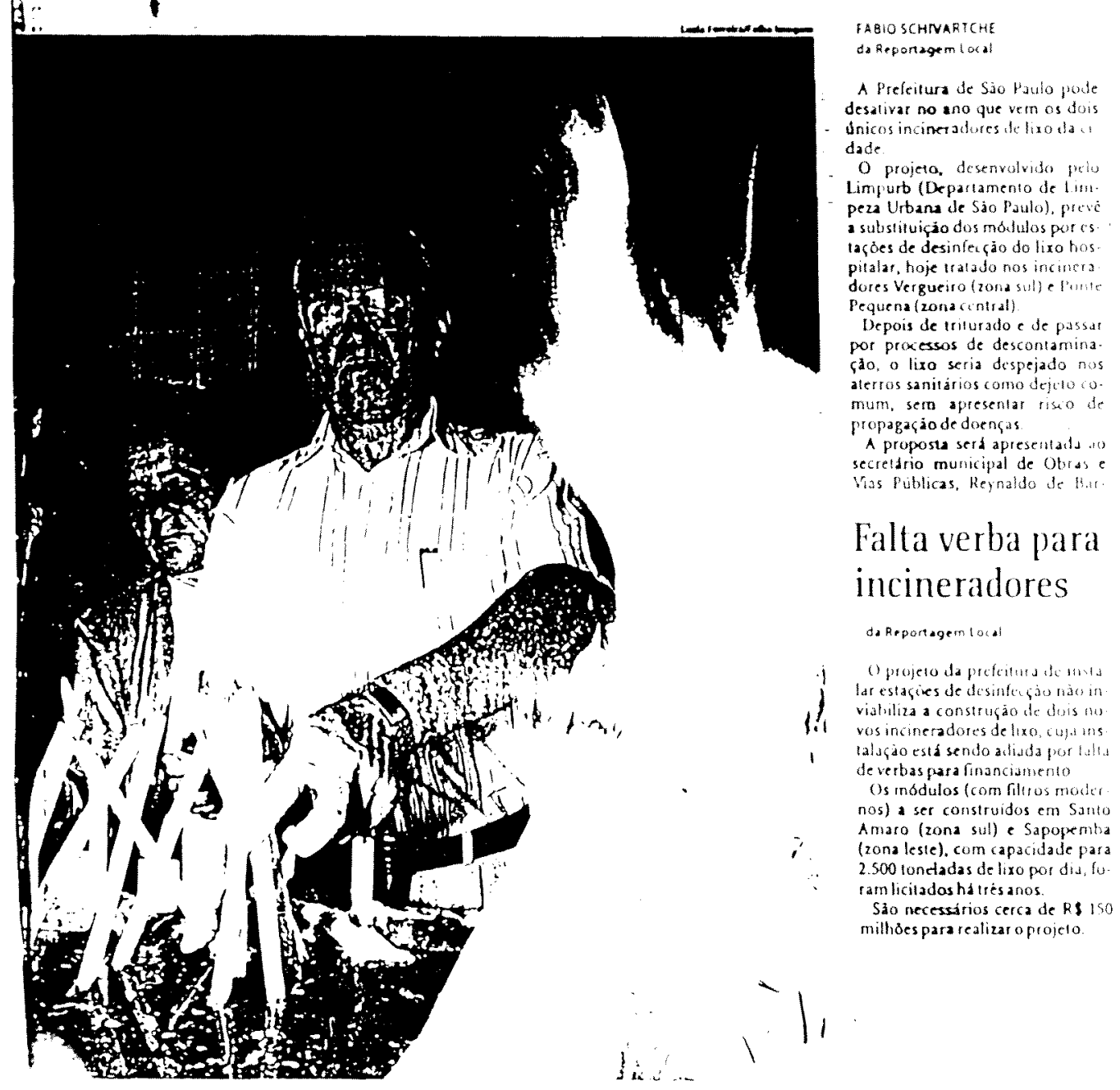




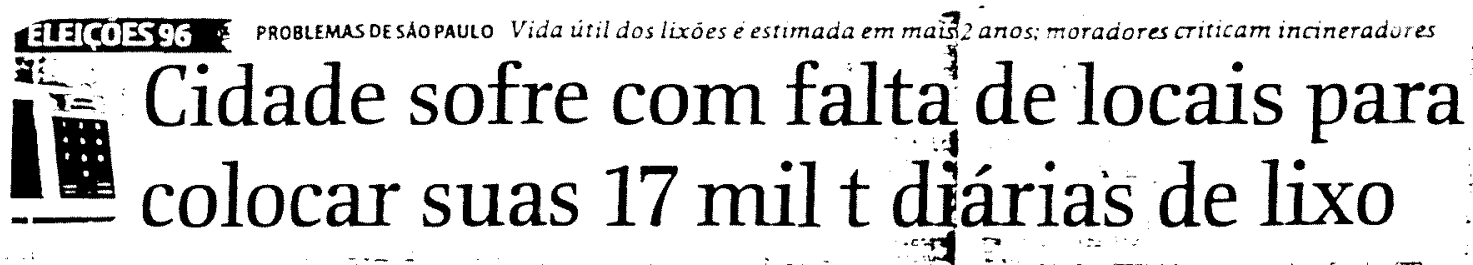

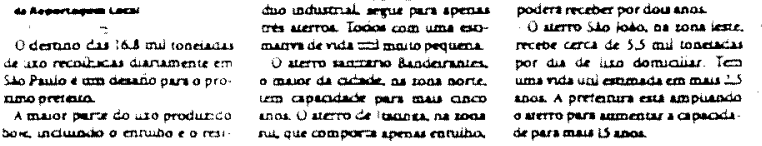

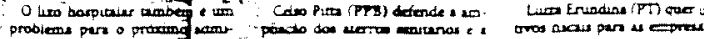

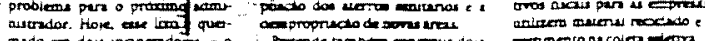

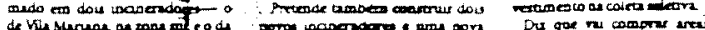

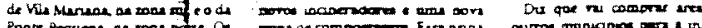

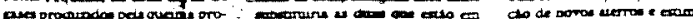
(1)

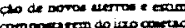
Moradores lutam há $10 \mathrm{ang}$ a pelo fechamento de aterrs

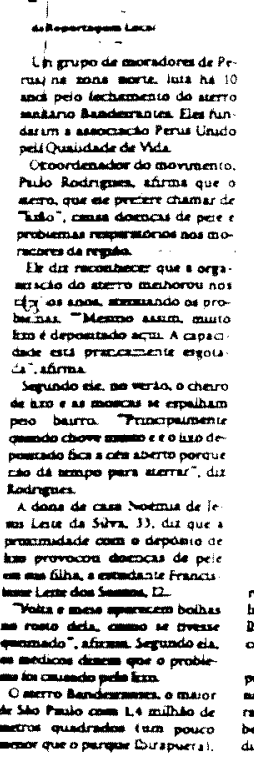

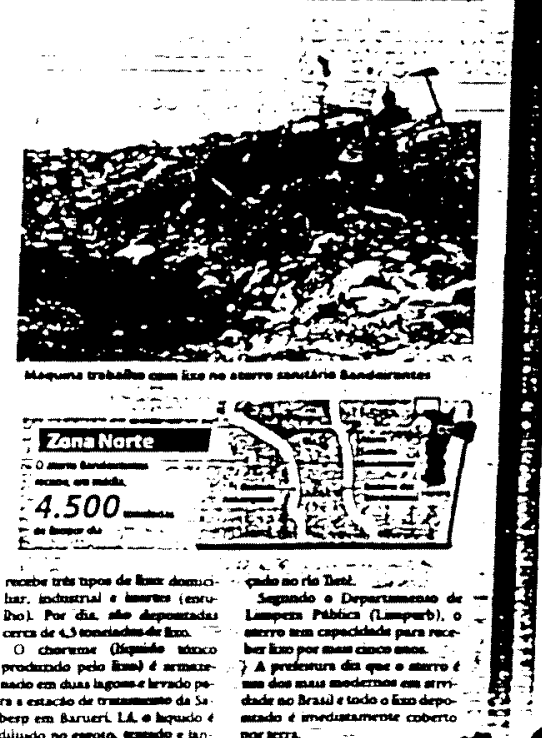

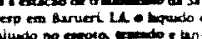

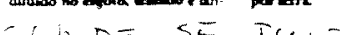
ameaça parque do Carmo

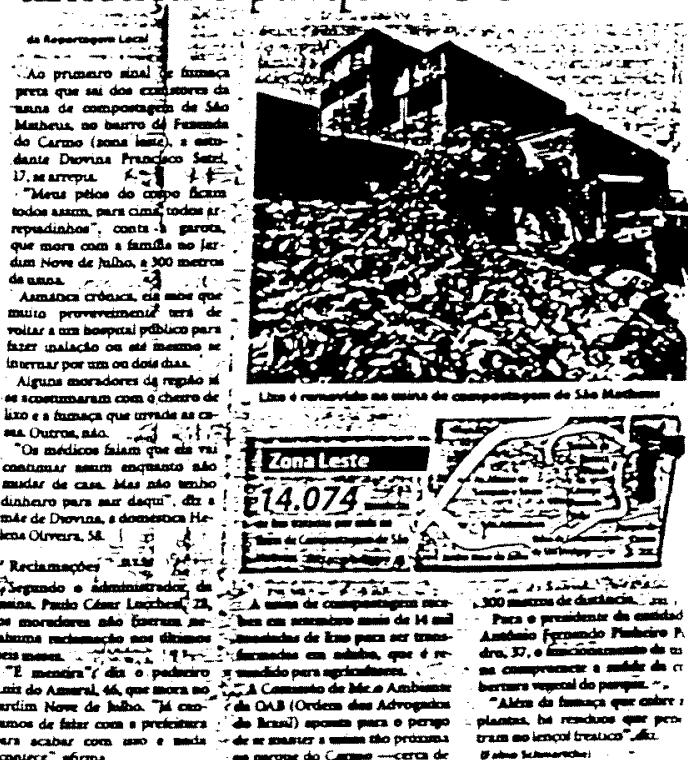




\section{JOSE LOPEZ FEIJOO}

Gostaramos de discordar opiniào do sr. Paulo Planet Bu que, consciheiro do Tribuna Conias do Municipio, expressa artigo "O lixo de Sào Paulo" tha, 18/12/96).

Em recentes discussócs pro vidas por entidades da socied civile do meio sindical, nas qur CUT leve participacio, tomos evidente a cxistenca dc attern vas mass saudaveis ao ser huma c ao meso ambiente para o it produzido na cidade de Sio $P$ a do que o uso de incineradores. mo foi sugerido pelo advogado. A í coninceida coleta scictid uma dclas. Mas ha tambem a co: postagem, que iransiorma a auvoo o ixxo organico. Mas metade do lixo brastieiro $-61 \%$. $e$ de aualcrais organicos.

$A$ reciclagcm e a reutilizaçiol cmbalagcris, garralas e outros a ierials lambem sajo tormas den tar a queima do lixo.

E sabido nundialmente que: momeradores criam riscos a so de. A queima do lixo libera dio nas e furanos, substancias contaminam o at e a agua c dest auelam docncals como cani atrofia nos tesiculos, tremore perda de memoria quando nost organismos as absorvem. meso que selam pequenas quantidadé Ou scja, os incincradores Itocd produtos tóxicos por outros ain mais toxicos. E custam caro. Ala disso, nào estranho que as usit suriam como opcào lustame quando deixaram de ser acettas: seus patses de origem?

No Reino Unido, onde o sr. f net buarque disse ter sentido "I clusive na boca das chamines nenhum upo de dano ao meto $x$ biente ha com aquela altissima u nologia". Coram fechados otlo" cineradores nos últimos anos. $N$ EUA foram fcchados 280 , na $\mathrm{Es}$ nha, 31; na polonia, 21: e na $A$ : iralia, 10.

Ainda no Reino Unido, conr. lou. 5 e $\mathrm{cm} 1990$ yue o lixo quar. do pelos incincradores cra a pri cipal fonte de dioxinas. Cinco ar anies, o governo canadense hro idenuficado o mesmo probler Na Holanda. a constatacáo os reu cm 91. c nos EUA, cm 93;1 Succo, ha mats de uma decada.

kecentemente. o BC vetou proicto de financiamento construcáo de incineradores, 2 : culado pelo atual prefeito. O prei to fazia do municipio avalisia construtoras, oterecendo as :a desimadas a limpeza pubica co: guranua para cmprestumos ban rios. Como se ve. há um lobbypa a consituço de incineradores

Eimportante que o problema icia ' comecando a causar prea pacóes a administraça da ci de", como alirma o conseine Mas nao scra com o patrocin usinas de lixo que sera resolvido 
OPINIAO

Sobre a incineração

Agrava-se o problema do desu no final do nosso lixo sólido. $D_{n}$ minuem os espaços disponiven para lixöes e aterros sanitarios. Lo go ninguein vai saber o que faze com as $11 \mathrm{mil}$ ou $12 \mathrm{mil}$ tonelada de lixo que geramos diariamente na nossa gigantesca cidade.

na nossa gigantesca cidade.
Com isso, acirrolu-sc antiga polt mica sobre incineradures de lixo constroem-se ou nào essas "pe ças" na cidade?

Para os opositores (que sào mu (os), csses "monstros poluido res" mais complicam do que aju. dam: methor seria adotar moder. nas e ecológicas tecnicas de rea proveitamento do lixo.

Mas a pref́cilurn pensa diferente

E ate já deu os primeiros passor providenciou proietos para tro "usinas de processamento de resa duos sólidos domiciliares", ne zonas sul, leste c oesic. Cada usina devera ler trés modu.
los de incineraçao, cada um con capacidade de 480 l de lixo/da chamine de $100 \mathrm{~m}$. precipitada cletrostático c lavador de gase - para controlar materia particu Iada, SO, CO. HCL e HF (ser controles especificos para dioy nas, turanos e metais pesados).

Consta, tambern, que tudo fa devidamentc aprovado pelos an tores dos LiN/Kima (listudo d* Impactos Ambientais/Relatório or Impactos ao Meio Ambiente), pe los consultores Proema e Fipe pelo Cades (Conselho Municipa) do Mcio Ambicinle c Descinvoln mento Sustentável). Näo obstante. - empreendimento encontra-x embargado pela lustiça.

Os prognosticos de qualidade d. ar apresentados pelo EIA (cupor resultados deveriam embasar escolhas das milugaçóes dos in - pactos atmosíericos) consi pactos dimosítricos) consi
lucin-sc, ho chtanto, cm mayuia gens sofisticadas.

As simulaçóes de dispersào du poluentes foram ieitas para cent rios sazonais alimentados por $\mathrm{dz}$ jos meicorológicos médios luk dez anos), no lugar de cenarios de dias críticos. Os impactos atme féricos nos dias criticos (no mur. mo. uma dezcra por ano) deveric mo. uma dezcra por

ser multo matores. "malditos incineradores", que $x$ cxijan, pelo menos, duas garan (ias: l) que sciam temporários yuantidade de lixo incincrada da riamente deverá diminuir. mesma medida em que se consip aumentar a de lixo reciclado; que as manutencóes dos sistem de controle de emissóes de $p$ luentes, constantes do projeto, $x$ jam rigorosamente fiscalizadas. Além disso, espera-se que os ro ponsaveis ajam com os pes no chjo e sem maquagens (como a id citada). Caso contrario, coloca em operacalo Irés incineradores $\alpha$ grande porte (1.400 toneladas d lixo/dia), anda que por powo tempo, sera uma temeridade. 


\title{
Fentograma
}

\author{
WERNERE. ZULAUF
}

A implantigame, pela loutcitura

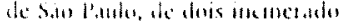

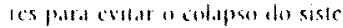
m.t de destmogio final de lixu d.t

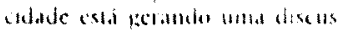
sio totalmente imbits, mis detica-

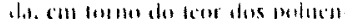

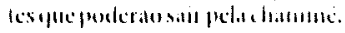

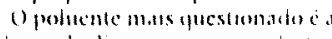

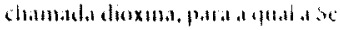
cretain Mumictipl do Verde e do Mein Ambiente estabdecen at

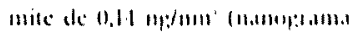

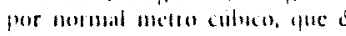

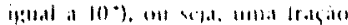

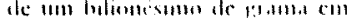

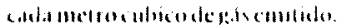

$A$ chamums, de com inctons de al

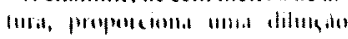

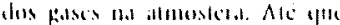

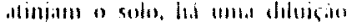

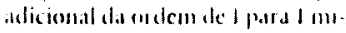

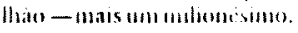

O yue e issu? lisse teot c mensu. r ducl? laz nusl a saute? Ten clici ro? Diat dite nho e ponco convm. (ente, combens ventadenos

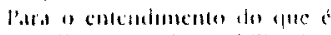
the milioneswo de um bilionesi. mo $\left(10^{\circ} \times 11^{\circ}=10^{n}=\right.$ tum tent

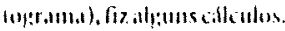

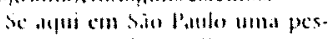
soa hacir, lodes as dias, urma co. Her pequenat de sal no licte (um) Framat isso nato vid alterar cm nat-

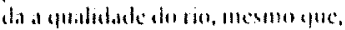

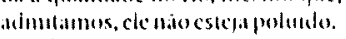

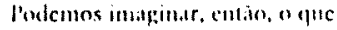

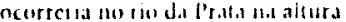
de buenos Aires, ilcpois de meses ou anos de adicion de um grama por dist de sal con Situ Patulu. Se nem no locial da adigito at dos.liem seraf perceplivel, imbline-se als.

Mas os ntmeros permitem lido. inclusive calcular de guanto serdi al

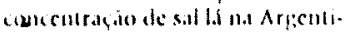

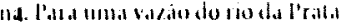
lé33 milhoes de litros/segmolo, a concentrasion serit de 350 fi:/ (6en.

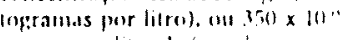
grimasporliesode afuat do row.

Compillation ans toreses die dioxi. na des incinctaderes, a concentraçio de sal do rio sará 2.500 ve. zes superine a concentrasion de dioxihas no ar de Sín l'alulo. que será menor do yue 0.1.t fentoperdma por mi de ir na altura do solo, concontatocoma a populacion.

Fentoprama năo e palavriu nem e messurativel. Eapenis un niancso fácil de calcular, cmbora possivel de medir, coino o atumenpossivel de medir, coino o atumen-
to da salinidale do rio da l'rata pe. la adicio de un freramal de s.l cm Sio l'aulo. Reconicndo ans intmalislas, formadores de opiniao, c aos críticos sistcruáticos dis inichativas de governo pue modicm um penco subre a juconsistencha dos areumentos de delerminadas linhas de pensancento ideologion.

$\Lambda$ incincrasio cm Sin P'inlo ser.l toma açio de macrourecichasem de lixo, com provia thiagem de pro. dates puta reutilizatan industral c poslerior recuperacio de $20 \mathrm{me}$ grawalls por tuidide de encrgia. 
$\overline{\text { OPINIĀO }}$

A coleta seletiva

simultânea

\section{WERNER E. ZULAUF}

Iniciar mais tarde qualquer noia atwidade possibilita auferir vantagens, apropriando acertos $\mathcal{c}$ cvitando os erros cometidos pelos pionciros; mas exige senso critico, capacidade de avaliação e criatividade.

$\mathrm{Na}$ reciclagem de lixo, muitas ciaades, inclusive Säo Paulo, na gestāo Erundina (em escala minuscula, diga-se), adotaram a forma simplista de fazer colcta alternada.

Em certos dias era feita a coleta de lixo comum, em outros, a chamada "coleta seletiva". Näo percebiam aue estavam duplicando
- Hom mats caro dia lmpeza $u$ inama a colctado lixo.

Entre as movacoes da nora politica de limpeza urbana de Săo Paulo destaca-se " "Colcta selctira smultanea", a ser mpieneniada prostessuamente, ate a cobertura total da cidade, em poucosanos.

Trata-se da coleta precedida da scparacáo domestica do lixo em duas partes: "lixo organico" em um recipiente c "lixo seco" em outro.

A colocacio na calcada dos dois recipicntes sera feita no mesmo dia c hora: o cantmiano coletor tera dois compartmentos, am para o organico c outro para o seco.

Desse modo, na mesma viagem, com un so motorista, um só jogo de pucus, um so consumo de combustivel uma so guarniça de garis $c$ uma so viagem em cada circuito, scra transportado todo o lixo de cadia casa sem a necessidade de mistura-lo.

Com a adoçáo crescente dos "contcincres basculâveis", ia em uso experimental em alguns circuitos, scrá possivel ampliar o in-

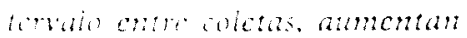
is andat mass a cconomm do uch nats caro, a coleta haver an contener para cada um do: dois tipos de ixo).

No local de destino final scit am atcro saniario on wa incineraior, iatcra win posto do inagem. hoal con que o tho sea scra submctio a separacio dus componcntes para os quats hana mercado.

Como essa traçao näo teve con. tato com a fracaio oremica, muito facil proccicr a scparacion, scia cia mamal oumccinica.

A otcrta de quantidades granics de alummio, ferro, PET, pafel, papelao, vidro e plastico ira cstimuiar a tinda de tecnologias de reciclagem aue ia se desenvolreram de foma impressionante cull outros paises e mesmo em $\mathrm{cl}$ diades brasilciras.

Werner Eugenio Zulauf, 61 , engenherro covit monitansid e cecetario mumicinal do verde oo hero amoerte o sio pauto e piestoente na cionsl ca Anamma Lssociasao Nacional de Mu. hlsiaj e Mnio Ambiente: Fo: presiaente da

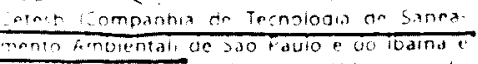

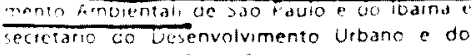
Mmo Ameienic ce Santa Catarina 


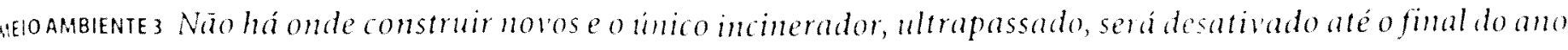 \\ Aterros de SP se aproximam da saturação}

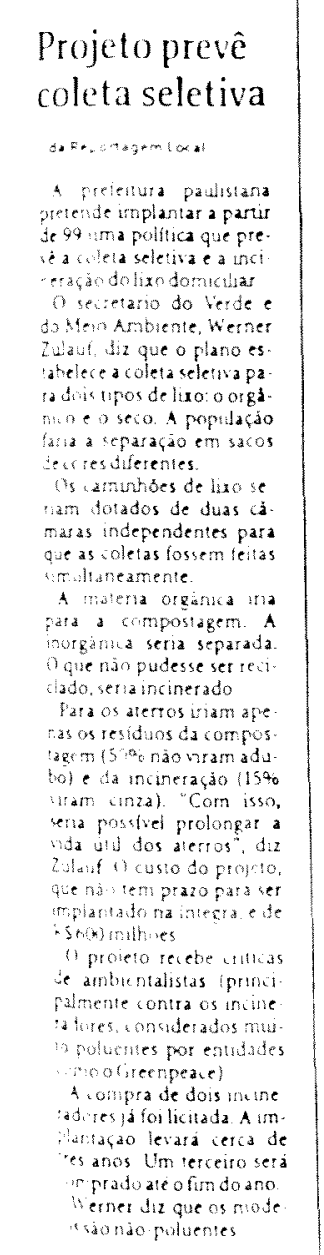

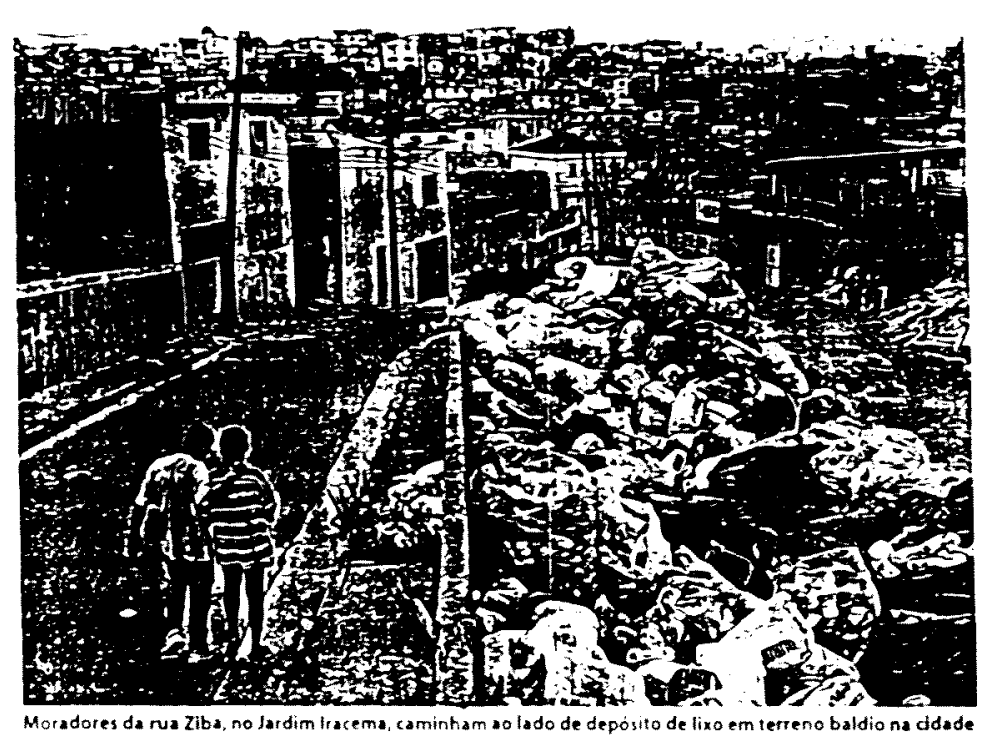

Alemanha discute como eliminar o lixo
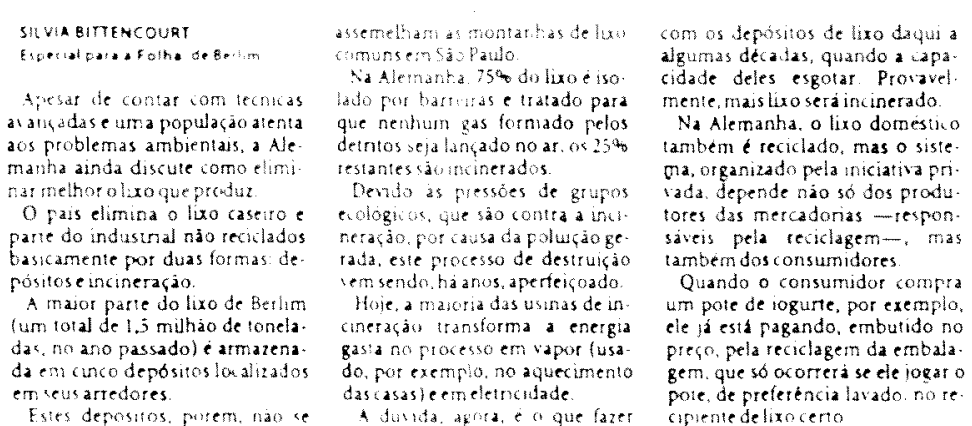

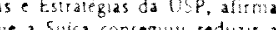
geracáo de lixo exigrido que a $p$

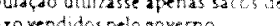

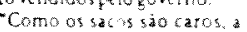

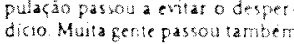
a desembalaz us produlos na salida que as redes pressionassem os ta.

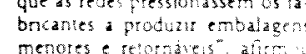
oeconomisata

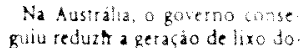
mikciliar recolbendo gratuilamentie

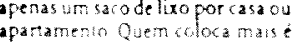

Reciclageerm

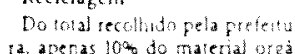

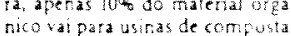

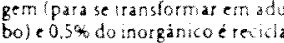

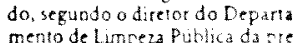

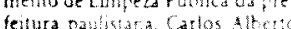

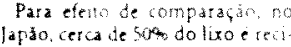
biemas a muios materiatis", afirma limit

Na prina de faulo Rowng: Protesáa Ambential\}, e porstive

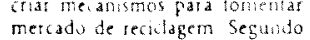

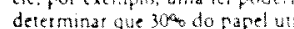
Lizado pela buroctacia publica fos se obngatoriamente inpresio em
material recidado $R G$. 
Anexo 4 - Levantamento de fontes por matéria publicada no jornal Folha de S.Paulo 


\begin{tabular}{|c|c|c|c|c|}
\hline $\mathrm{N}^{\circ}$ & Título da materia & Data: & Qualifícação da fonte: & N. Fontes \\
\hline $1^{\circ}$ & $\begin{array}{l}\text { Concorrència do lixo fere lei de } \\
\text { licitação }\end{array}$ & $04 / 02 / 940$ & $\begin{array}{l}\text { - Politico favoravel } \\
\text { - Politico em oposição }\end{array}$ & 2 \\
\hline $2^{\circ}$ & $\begin{array}{l}\text { Prefeitura suspende o "embargo" do } \\
\text { lixo }\end{array}$ & $10 / 02 / 94$ & $\begin{array}{ll}\text { - } & \text { Empreendedor } \\
\text { - Orgão governamental - proponente } \\
\text { - } \quad \text { Politico em oposição } \\
\end{array}$ & 3 \\
\hline $3^{\circ}$ & $\begin{array}{l}\text { Três empresas na entram na licitação } \\
\text { das usinas }\end{array}$ & $11 / 02 / 94$ & $\begin{array}{l}\text { - Politico em oposição } \\
\text { - Orgão governamental - proponente } \\
\text { - Empreendedor }\end{array}$ & 3 \\
\hline $4^{\circ}$ & $\begin{array}{l}\text { S.P recicla apenas } 0.06 \% \text { do lixo } \\
\text { produzido }\end{array}$ & 100494 & - Orgão governamental - proponente & 1 \\
\hline $5^{\circ}$ & $\begin{array}{l}\text { Moradores protestam contra usina de } \\
\text { lixo }\end{array}$ & $26 / 05 / 94$ & $\begin{array}{l}\text { - Orgão governamental-proponente } \\
\text { - Movimento social }\end{array}$ & 2 \\
\hline $6^{\circ}$ & Cidade importa incinerador de lixo & $20 / 06 / 94$ & $\begin{array}{l}\text { Orgão governamental - proponente } \\
\text { - Organização não governamental }\end{array}$ & 2 \\
\hline $7^{\circ}$ & Ambientalistas apontam risco de câncer & $20 / 06 / 94$ & $\begin{array}{l}\text { - Organização não governamental } \\
\text { - } \quad \text { Movimento social } \\
\text { - Orgão governamental-proponente } \\
\text { - Empreendedor }\end{array}$ & 4 \\
\hline $8^{\circ}$ & $\begin{array}{l}\text { Protesto reune } 1.500 \text { contra construçào } \\
\text { de usina de lixo }\end{array}$ & $30 / 06 / 94$ & $\begin{array}{l}\text { - Movimento social } \\
\text { - Orgào governamental-proponente }\end{array}$ & 2 \\
\hline $9^{\circ}$ & $\begin{array}{l}\text { Prefeitura sera 'avalista de coletora de } \\
\text { lixo }\end{array}$ & $02 / 07 / 94$ & $\begin{array}{l}\text { Orgào governamental proponente } \\
\text { - Movimento social }\end{array}$ & 2 \\
\hline $10^{\circ}$ & Estudo condena incinerador & $16 / 09 / 94$ & $\begin{array}{l}\text { - Universidade } \\
\text { - Orgão governamental - proponente }\end{array}$ & 2 \\
\hline $11^{\circ}$ & $\begin{array}{l}\text { Teste em cobaias comprovam risco à } \\
\text { saúde }\end{array}$ & $16 / 09 / 94$ & $\begin{array}{ll}\text { - } & \text { Universidade } \\
\text { - Organização não governamental } \\
\text { - Orgão governamental - proponente }\end{array}$ & 3 \\
\hline $12^{\circ}$ & Olixo em S.P & $01 / 10 / 94$ & - Empreendedor & 1 \\
\hline $13^{\prime \prime}$ & $\begin{array}{l}\text { Decisão do BC atrapalha plano de } \\
\text { incineraçào da prefeitura }\end{array}$ & 151294 & $\begin{array}{l}\text { - Orgão governamental regulador } \\
\text { - Orgão governamental-proponente } \\
\text { - Politico em oposição }\end{array}$ & 3 \\
\hline $14^{\circ}$ & Zulaut defende usina que antes atacava & $19 / 12 / 94$ & - Orgão governamental - proponente & 1 \\
\hline $15^{\circ}$ & A reciclagem de lixo & $21 / 03 / 95$ & - Políticos favoraveis & 1 \\
\hline $16^{\circ}$ & Especialista faz critica a incineradores & 220399 & - Universidade & 1 \\
\hline $17^{\circ}$ & Gas de incineraçào pode causar cảncer & 210895 & $\begin{array}{l}\text { - Universidades } \\
\text { - Orgào governamental - proponente }\end{array}$ & 2 \\
\hline $18^{\circ}$ & Malut quer usina ao lado de parque & 210895 & $\begin{array}{l}\text { Orgào governamental regulador } \\
\text { - Empreendedor }\end{array}$ & 2 \\
\hline $19^{\circ}$ & $\begin{array}{l}\text { Aterros da prefeitura so tem capacidade } \\
\text { para mais } 3 \text { anos }\end{array}$ & $18 / 09 / 95$ & - Orgào governamental-proponente & 1 \\
\hline $20^{\circ}$ & O que ei incineraçào? & $30 / 06 / 96$ & - Orgão governamental - proponente & 1 \\
\hline $21^{\circ}$ & A ameaça dos residuos urbanos & $2708 / 96$ & - Orgão governamental regulador & 1 \\
\hline $22^{\circ}$ & $\begin{array}{l}\text { Lixo hospitalar pode ter novo } \\
\text { tratamento }\end{array}$ & $29 / 10 / 96$ & $\begin{array}{l}\text { - Orgão governamental - proponente } \\
\text { - Organização não governamental }\end{array}$ & 2 \\
\hline $23^{\circ}$ & $\begin{array}{l}\text { Cidade sofre com falta de locais para } \\
\text { colocar suas } 17 \text { mil t diarias de lixo }\end{array}$ & 301096 & $\begin{array}{l}\text { - Político favoravel } \\
\text { - Politico em oposição } \\
\end{array}$ & 2 \\
\hline
\end{tabular}




\begin{tabular}{|c|c|c|c|}
\hline Dos males. males é o incinerador & $14 / 01 / 97$ & 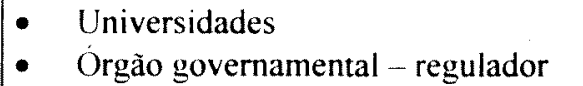 & 2 \\
\hline Sobre a incineração & $11 / 04 / 97$ & $\begin{array}{ll} & \text { Politico em oposição } \\
\text { - Orgão governamental - proponente } \\
\text { - Empreendedor }\end{array}$ & 3 \\
\hline Fentograma & $06 / 02 / 98$ & - Órgão governamental - proponente & 1 \\
\hline A coleta seletiva simultânea & $24 / 06 / 98$ & - Politico em oposição & 1 \\
\hline $\begin{array}{l}\text { Aterros de S.P se aproximam da } \\
\text { saturação }\end{array}$ & $04 / 10 / 98$ & $\begin{array}{l}\text { - Órgão governamental - proponente } \\
\text { - Organização não governamental } \\
\text { - Orgão governamental - regulador } \\
\text { - Empreendedor } \\
\text { - Universidade }\end{array}$ & 5 \\
\hline
\end{tabular}

